UNIVERSIDADE DE SÃO PAULO

ESCOLA DE COMUNICAÇÃO E ARTES

Leticia Maria Olivares Rodrigues

Em um corpo só - crônica de uma atriz-pesquisadora em contato com a tradição do Odin Teatret

São Paulo 
Leticia Maria Olivares Rodrigues

Em um corpo só - crônica de uma atriz-pesquisadora em contato com a tradição do Odin Teatret

Dissertação apresentada à Escola de Comunicação e Artes da Universidade de São Paulo ECA/USP - para a obtenção do título de Mestre em Artes Cênicas.

Área de concentração: Texto e Cena.

Orientadora: Prof. ${ }^{a}$ Dr. ${ }^{a}$ Sayonara Pereira

São Paulo 
Autorizo a reprodução e divulgação total ou parcial deste trabalho, por qualquer meio convencional ou eletrônico, para fins de estudo e pesquisa, desde que citada a fonte.

Catalogação na Publicação

Serviço de Biblioteca e Documentação

Escola de Comunicações e Artes da Universidade de São Paulo

Dados fornecidos pelo(a) autor(a)

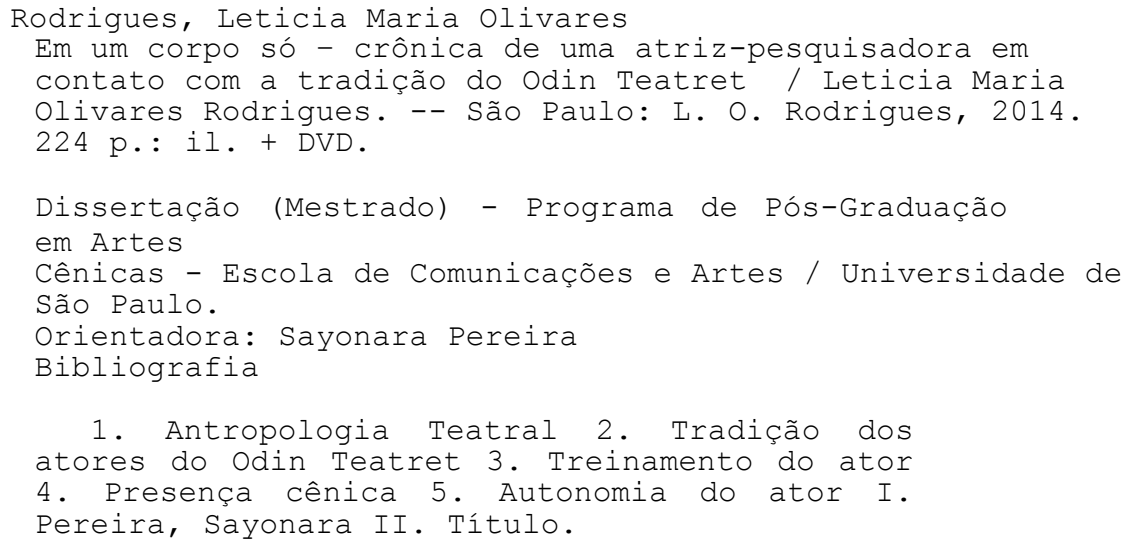


Nome: RODRIGUES, Leticia Maria Olivares.

Título: Em um corpo só - crônica de uma atriz-pesquisadora em contato com a tradição do Odin Teatret

Dissertação apresentada ao Programa de Pósgraduação em Artes Cênicas (Linha de Pesquisa: Texto e cena) da Escola de Comunicações e Artes da Universidade de São Paulo para a obtenção do título de Mestre em Artes Cênicas.

Aprovado em

Banca examinadora:

Prof. ${ }^{a}$ Dr. ${ }^{a}$ Sayonara Pereira Instituição: Universidade de São Paulo - USP.

Julgamento: Assinatura:

Prof. ${ }^{a}$ Dr. ${ }^{a}$ Marília Velardi

Instituição: Universidade de São Paulo - USP.

Julgamento: Assinatura:

Prof. ${ }^{a}$ Dr. ${ }^{a}$. Verônica Fabrini Instituição: Universidade de Campinas - UNICAMP. Julgamento: Assinatura: 
À minha avó Tina (in memoriam);

Ao Fábio;

Àqueles que têm um jaguar dentro de si. 


\section{AGRADECIMENTOS}

À mãe Antonia que me apresentou as delícias de ser palhaço, o teatro, a literatura e a beleza das artes. Ao pai Heitor que traduz o carisma, o viver aqui e agora e a capacidade de se reinventar. À irmã Milena, que me dava a mão na hora do medo e é mãe do sobrinho mais amado, Pedro. E à irmã Clarissa, dona de tantos talentos, que me inspiram e desafiam.

A Gonzaga Pedrosa, que iluminou meu caminho.

À querida Prof. ${ }^{a}$ Sayonara Pereira, orientadora que reúne o melhor de dois mundos: a afetividade brasileira e o rigor alemão, com sua condução sempre generosa, sensível, sincera.

Aos colegas, funcionários e professores da USP. Especialmente à Prof. ${ }^{a}$ Elizabeth Lopes pela confiança e oportunidades.

Ao Odin Teatret Nordisk Teaterlaboratorium com todas as pessoas que o formam e que tão generosamente acolheram minha presença e busca. Sobretudo à Julia Varley e Eugenio Barba. São meus mestres invisíveis; estão comigo na sala de ensaio, nas aulas que ministro e em cada linha desta escrita.

À Luciana Martuchelli, Juliana Zancaro, Filipe Lima e equipe da Arte Secreta do Ator Brasil, que criaram pontes e trouxeram os mestres para perto, com competência e afeto.

À Maíra Spanghero, a melhor amiga, sábia, divertida e confidente.

À amiga Stela Fischer, parceira e incentivadora; e Monica Siedler e Léia Rapozo, por também partilharem sonhos e realizações.

À Juliana Caligaris, Antonio Ginco, Monalisa Vasconcelos e Lucas Barbosa, que se entregaram em minhas mãos no trabalho Catadióptrico.

A Rubens Curi, diretor amigo que enxerga minha alma.

A Celso e Aline Reginato pelo suporte generoso e filosofia de vida inspiradora.

E a Fabio Reginato, meu amor e o melhor companheiro e aliado que tive a sorte de encontrar nesta vida. 
A essência da técnica moderna põe o homem a caminho do de-sencobrimento que sempre conduz o real, de maneira mais ou menos perceptível, à dis-ponibilidade. Por a caminho significa: destinar. Por isso, denominamos de destino a força de reunião encaminhadora, que põe o homem a caminho de um desencobrimento. É pelo destino que se determina a essência de toda a História.

Martin Heidegger 


\section{RESUMO}

RODRIGUES, Leticia Maria Olivares. Em um corpo só - crônica de uma atrizpesquisadora em contato com a tradição do Odin Teatret. 2014. 224 f. Dissertação (Mestrado) - Escola de Comunicações e Artes, Universidade de São Paulo, São Paulo, 2014.

A presente pesquisa, de cunho teórico-prático, apresenta o registro dos procedimentos de preparação técnica e montagem do diretor e atores do Odin Teatret segundo a ótica da Antropologia Teatral e persegue as noções de presença cênica e autonomia do ator. A partir da vivência da tradição de seus atores e documentação realizada em campo sobre treinamento e criação por eles difundidos, são selecionadas, descritas e experimentadas técnicas aplicadas na preparação pré-expressiva e em uma composição cênica pessoal. Na revisão de literatura, estabelece o diálogo com a linhagem de diretores-pedagogos do século $\mathrm{XX}$, como Stanislavski e Grotowski e com estudiosos e críticos da Antropologia Teatral. Na aproximação com o conceito de presença, traz Hans Ulrich Gumbrecht para introduzir as noções de dramaturgia usadas por Eugenio Barba. Os registros e análises se valem de pressupostos da pesquisa qualitativa por meio da autoetnografia para sua organização. A identificação dos procedimentos mapeia as aplicações atualizadas das tradições do Odin Teatret. Por fim evidencia o percurso de personalização dos estímulos, sua aplicação pedagógica e o processo de montagem de materiais na dramaturgia da atriz-pesquisadora. Por meio de seus agentes, a pesquisa permitiu apurar as noções que perseguia sobre o trabalho técnico e o processo de autonomia do ator.

PALAVRAS-CHAVE: Antropologia Teatral. Tradição dos atores do Odin Teatret. Treinamento. Presença cênica. Autonomia do ator. 


\begin{abstract}
RODRIGUES, Leticia Maria Olivares. In one body - chronicle of an actressresearcher in touch with the Odin Teatret's traditions. 2014. 224 f. Dissertação (Mestrado) - Escola de Comunicações e Artes, Universidade de São Paulo, São Paulo, 2014.

This research, of a theoretical-practical nature, introduces the register of the technical preparations' proceedings and production of the Odin Teatret director and actors, from the viewpoint of the Theatre Anthropology, and it pursuits the notions of scenic presence and the actors' autonomy. Based on the experience of its actors' tradition, and on a documentation held in fieldwork, about training and creation widespread by them, applied techniques are selected, described and experimented in the pre-expressive preparation and in a personalscenic composition. In the literature review, it establishes a dialogue with the lineage of directors-pedagogues from the $20^{\text {th }}$ Century, such as Stanislavski and Grotowski, and with scholars and critics of the Theatre Anthropology. In the approximation of the presence concept, it brings Hans Ulrich Gumbrecht to introduce dramaturgy notions used by Eugenio Barba. The registers and analysis rely on assumptions of the qualitative research using autoethnography to its organization. The identification of the proceedings maps the updated applications of the Odin Teatret's traditions. Lastly, it evidences the course of stimuli personalization, its pedagogical application and the material production process in the actressresearcher's dramaturgy. By its agents, the research allowed to ascertain the notions it searched about the technical work and the actor's autonomy process.
\end{abstract}

KEYWORDS: Theatre Anthropology. Odin Teatret actor's tradition. Training. Scenic presence. Actors' autonomy. 


\section{LISTA DE FIGURAS}

Figura 1. Fita de Moebius. Manipulação digital: Leticia Olivares. .........................................26

Figura 2. My stage children com Else Marie Laukvik. Foto oficial do Odin Teatret.

Figura 3. Andrógina. Festuge, Holstebro, 14 e 18/06/2014. Fotos e montagem: Leticia

Olivares

Figura 4. Iben Nagel Hasmussen em A Vida Crônica. Foto oficial do Odin Teatret................ 48

Figura 5. Tage Larsen em A vida Crônica. Foto Oficial do Odin Teatret................................ 49

Figura 6. Roberta Carreri em A Vida Crônica. Foto oficial do Odin Teatret............................50

Figura 7. Julia Varley em A Vida Crônica. Foto Oficial do Odin Teatret. ...............................51

Figura 8. Jan Ferslev em demonstração de trabalho. Foto oficial do Odin Teatret..................52

Figura 9. Frans Winther e Else Marie Laudvik em Memória. Foto oficial do Odin Teatret....53

Figura 10. Kai Bredholt em A Vida Crônica. Foto oficial do Odin Teatret...............................54

Figura 11. Prática de Tai chi chuan. A Arte Secreta do Ator - Brasil, 2011.............................56

Figura 12. Brincar, marchar, caminhar, ao chão... A Arte Secreta do Ator - Brasil, 2010.

Foto: Edu Barroso. 61

Figura 13. Entrega de certificado. A Arte Secreta do Ator - Brasil, 2012. Com Luciana

Martuchelli, Eugenio Barba, Leticia Olivares e Julia Varley. Foto: Ricardo Calixto. 64

Figura 14. Oposições. A Arte Secreta do Ator - Brasil, 2013. Foto original: Edu Barroso. Intervenções: Leticia Olivares.

Figura 15. Apresentação do "cartão de visita". Tema: A flor das idades. A Arte Secreta do Ator - Brasil, 2010. Foto: Edu Barroso.

Figura 16. Lançamentos. A Arte Secreta do Ator - Brasil, 2010. Com George Gottheiner. Foto: Edu Barroso. 87

Figura 17. Celebração. A Arte Secreta do Ator - Brasil, 2009. Foto: Marcelo Dischinger...... 88 Figura 18. Foto da foto. Primeira visita ao local cedido em Holstebro para o Odin Teatret. Foto: Leticia Olivares por ocasião da exposição dos 50 anos do Odin Teatret em sua sede. Holstebro, Dinamarca, junho de 2014.

Figura 19. Entrada principal da sede. Odin Teatret, Holstebro, Dinamarca, 24/06/2014. Foto: Leticia Olivares. 95

Figura 20. Turma multicultural da Odin Week 2013. Foto: Tommy Bay. 103 
Figura 21. Push and pull - duplas. A arte secreta do ator-Brasil, 2010. Leticia Olivares (de costas) com Luciana Martuchelli. Foto: Edu Barroso.

Figura 22. Push and pull-individual. A arte secreta do ator-Brasil, 2010. Foto: Edu Barroso.

Figura 23. Ao céu. A Arte Secreta do Ator-Brasil, 2010. Foto: Patrícia Furtado de Mendonça.

Figura 24. Inspirações da art-noveau.

Figura 25. Naja e jo-ha-kyu em pares

Figura 26. Transferência de peso e impulso ou Suporting and being throwing. 159

Figura 27. Hook.

Figura 28. Desequilíbrio com giro.

Figura 29. Gangorra ou Up and down and sitting on the floor from side to side. 160

Figura 30. Kai Bredholt em apresentação de rua. Festuge, 2014. Holstebro, Dinamarca. Fotos e montagem: Leticia Olivares.

Figura 31. Else Marie e eu em seu escritório, após a entrevista. Holstebro, Dinamarca 25/08/2013. Foto: Else Marie Laukvik. 168

Figura 32. Gerônimo. Festuge, 2014, Holstebro, Dinamarca. Foto: Leticia Olivares. ........... 176

Figura 33. Fragmentos de textos. Foto: Leticia Olivares, 2010 ......................................... 191

Figura 34. Ensaio de EM UM CORPO SÓ. Foto: Fábio Reginato. São Paulo, 2014............ 196

Figura 35. Ensaio de EM UM CORPO SÓ. Fotos: Fábio Reginato. São Paulo, 2014. ......... 197

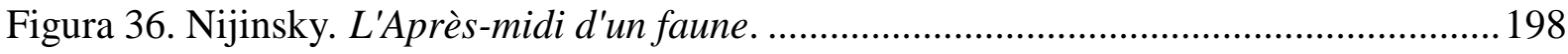

Figura 37. Ensaio de EM UM CORPO SÓ. Foto: Fábio Reginato, 2014 ............................. 201

Figura 38. Cena do filme $O$ Labirinto do Fauno. Dir. Guillermo del Toro (2006)...............202

Figura 39. EM UM CORPO SÓ. Foto: Fábio Reginato, 2014 ...............................................202

Figura 40. Em si mesmas. Campinas, UNICAMP, 2014. Fotos: Daniela Versiani. Montagem:

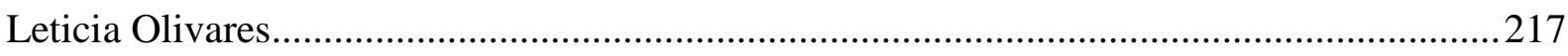

Figura 41. Catadióptrico. Fotos: Fábio Reginato, 2012. Montagem: Leticia Olivares. .........219 


\section{LISTA DE ABREVIATURAS}

BR - Brasil

CAN - Canadá

COL - Colômbia

DK - Dinamarca

ITA - Itália

ING - Inglaterra

ISTA - International School of Theatre Anthropology (Escola Internacional de Antropologia Teatral)

n.r. - nota de rodapé

NOR - Noruega 


\section{SUMÁRIO}

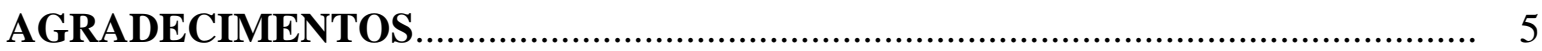

RESUMO

ABSTRACT

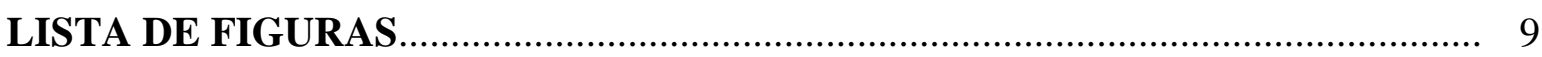

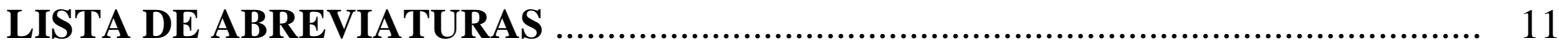

APRESENTAÇÃO: uma localização tempo-espacial afetiva de quem vos fala.......... 14

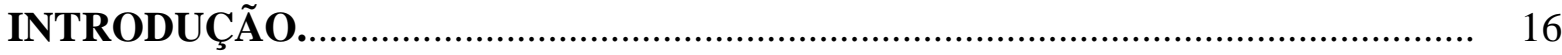

CAPÍTULO I - ESTRUTURA, HISTÓRIA E VIVÊNCIA..................................... 26

1.1 Filtros de organização: bricolagem metodológica e noções basilares......................... 26

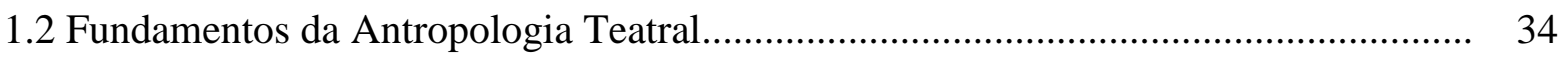

1.2.1 O ensemble: atrizes e atores do Odin Teatret na atualidade............................... 43

1.2.1.1 Else Marie Laukvik ............................................................................... 44

1.2.1.2 Iben Nagel Rasmussen.................................................................... 46

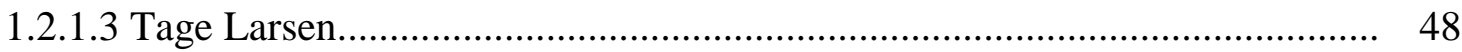

1.2.1.4 Roberta Carreri.................................................................................... 49

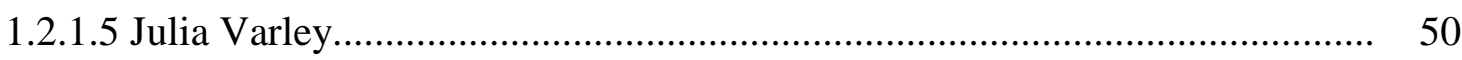

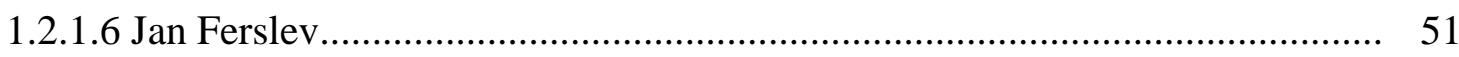

1.2.1.7 Frans Winther................................................................................... 52

1.2.1.8 Kai Bredholt................................................................................. 53

1.2.1.9 Atores mais recentes....................................................................... 54

1.3120 horas com Eugenio Barba e Julia Varley........................................................ 55

1.3.1 Sobre o acontecimento: forma e conteúdo...................................................... 58

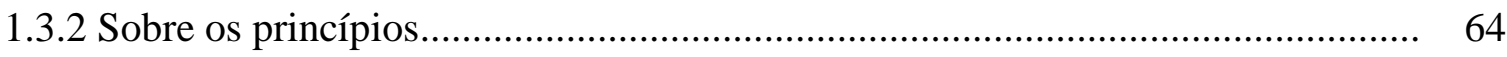

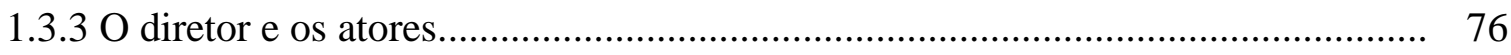

1.3.4 Trabalho com o texto.................................................................................. 83

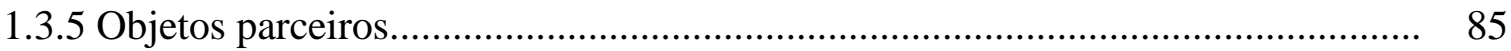

1.3.6 A convivência com os mestres (uma licença para impressões e adjetivos).......... 88

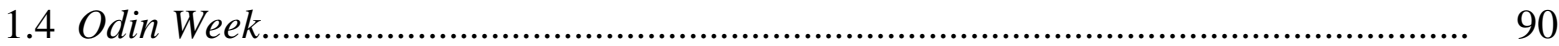

CAPÍTULO II - O DESVELAMENTO DO SER-ATOR …..................................... 104

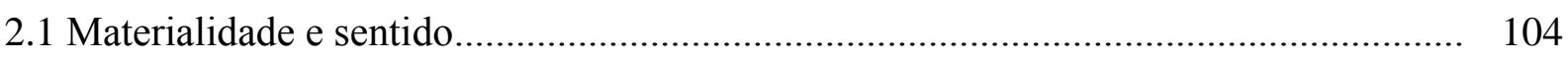

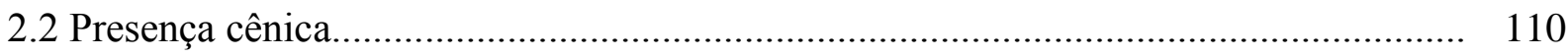

2.1.2 A aquisição técnica da presença........................................................................ 113 
2.2.2 O que é o treinamento e para o que serve?

2.3 Consciência corporal: contribuições para o corpo-em-vida do ator.

CAPÍTULO III - TRADIÇÕES DOCUMENTADAS: A PRÁTICA......................... 123

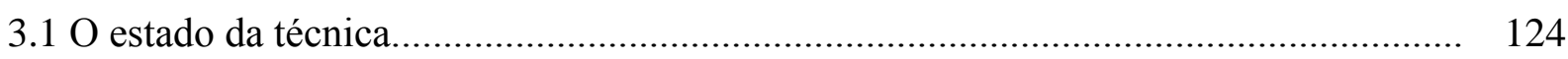

3.1.1 Tradição Julia Varley............................................................................. 126

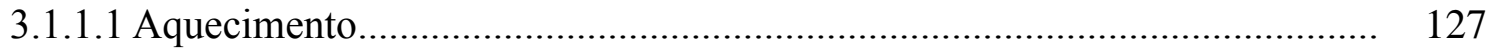

3.1.1.2 Exercícios com texto e/ou música.......................................................... 129

3.1.1.3 Exercícios com partituras corporais e vocais............................................. 135

3.1.2 Tradição Roberta Carreri............................................................................... 139

3.1.3 Tradição Iben Nagel Rasmussen.................................................................. 150

3.1.4 Tradição Jan Ferslev.................................................................................. 156

3.1.5 Tradição Tage Larsen..................................................................................... 157

3.1.6 Tradição Kai Bredholt.................................................................................... 160

3.1.7 Tradição Frans Winther....................................................................................... 163

3.1.8 Tradição Else Marie Laukvik............................................................................ 166

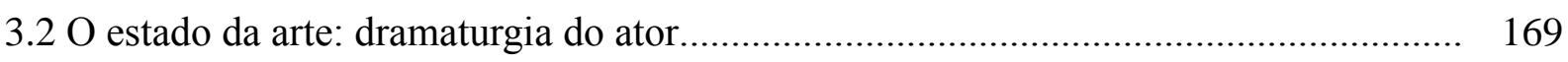

3.2.1 Partitura e subpartitura: precisão e transpassagens......................................... 169

3.2.2 Procedimentos compositivos ou modos de agir sobre os materiais...................... 174

CAPÍTULO IV- SANGUE E CÉREBRO................................................................ 179

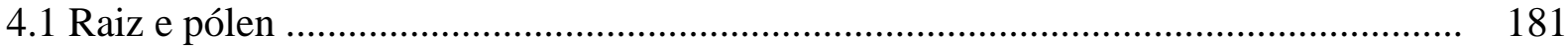

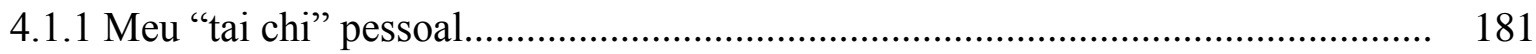

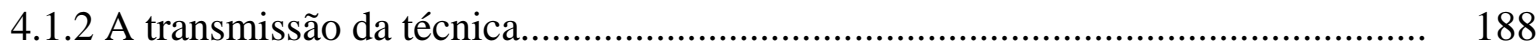

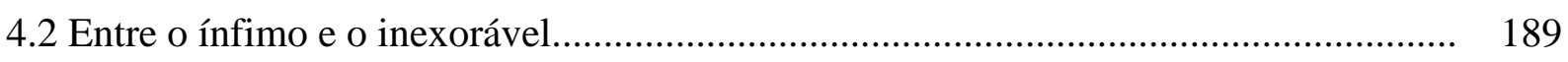

4.2.1 Notação da composição cênica EM UM CORPO SÓ......................................... 194

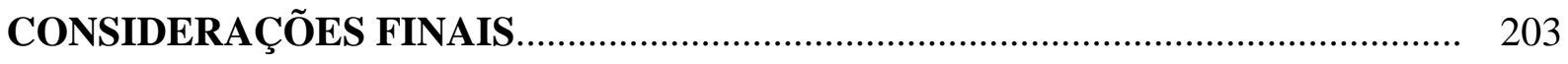

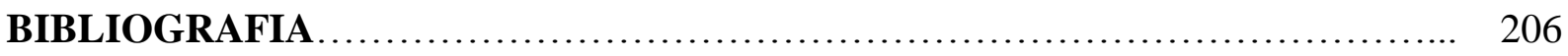

APÊNDICE - Processos Interligados..................................................................... 216

ANEXO - A Orientações A ARTE SECRETA DO ATOR - Brasil, Brasília, 2010

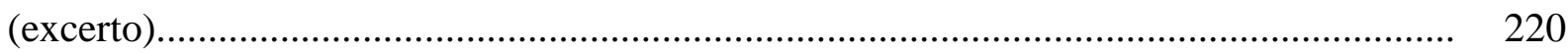

ANEXO B - Programação ODIN WEEK, Holstebro, 2013 (excerto).............................. 221

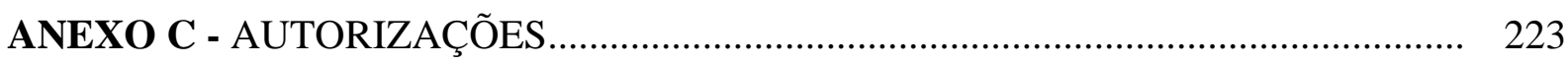

ANEXO D - ATIVIDADES DO NORDISK TEATERLABORATORIUM.................... 224 


\section{APRESENTAÇÃO: uma localização tempo-espacial afetiva de quem vos fala.}

Barba sempre vai se referir à biografia como um dos alicerces de todo artista em suas buscas e questões mobilizadoras da própria vontade. Para apresentar este trabalho acadêmico exponho, então, uma breve circunscrição autobiográfica, a fim de iluminar a necessidade e os trajetos desta escritura, os deslocamentos aos quais recorri e a escolha metodológica que foi adotada. Desde o começo da minha prática como atriz, ainda como amadora, na metade dos anos 1980, já os procedimentos a partir da fisicalidade para a construção de personagens eram os que mais me estimulavam. Vim de uma (de)formação no ballet clássico, para o qual nunca tive o physique $d u$ role ideal, mas, mesmo assim, sempre fui colocada em evidência nos espetáculos finais pela "expressividade". Um dia, uma professora me falou: "Você devia fazer teatro!" Interessada, me envolvi com um grupo amador. Na Cia. Avesso de Teatro (19861991) pratiquei treinamentos rigorosos que envolviam karatê, tai chi chuan, diversas modalidades de dança e exercícios do que se chamava na época de "expressão corporal”, além de treinos vocais, que me traziam a sensação de domínio e precisão para quando estava em cena. Porém, ainda sem saber, fui acumulando lesões como algumas hérnias cervicais e lombares, não desvinculadas a vulnerabilidades genéticas e aspectos fisiológicos como genuvalgo, afrouxamentos ligamentares nos tornozelos, condromalácia e tendência a artroses, descobertas ao longo da vida. A possibilidade de me tornar uma atriz, apesar de inúmeras limitações (ou a partir delas), decorria principalmente da curiosidade por aspectos do corpo, sua potencialidade em cena e, consequentemente, o estudo e aprofundamento sobre o mesmo. Durante a trajetória, já como profissional, passei a década de 1990 cursando variadas especializações nesse sentido: teatro-físico, yoga, consciência corporal e práticas somáticas, enquanto me sustentava como atriz em trabalhos devoradores - voltados para o teatro de treinamento corporativo, ao qual me dediquei por quatorze anos - por suas condições estressantes como pouco tempo de ensaio, montar e desmontar cenários em tempo recorde (e carregar o peso deles), locais e horários insólitos de apresentação, entre outras. Mas que, justamente por tais condições, também treinavam a capacidade de improvisação, presença ampliada e projeção descomunal da voz. Até que, no início dos anos 2000, fui arrebatada pelos procedimentos apresentados por um diretor que chegava de seus estudos na Europa, tendo passado pelo Odin Teatret, e que ministrou um workshop em São Paulo. A aplicação do treinamento objetivamente baseado nos princípios pré-expressivos, sobre os quais me aprofundarei ao longo da dissertação, gerou sentido para literatura de Barba, que eu acompanhava por meio de livros, artigos ou entrevistas. Esse arrebatamento levou há anos de 
treinamento e inúmeras "partituras corporais" movidas pela crença na ação física como procedimento de criação cênica. As aplicações pedagógicas e encenações que se seguiram, baseadas na dramaturgia corporal, fizeram que eu investisse ainda mais nessa escolha. Não coloco em foco os resultados, mas o processo de verticalização no entendimento/vivência dessas possibilidades, que se traduzem em uma linguagem que me faz sentido no nível límbico, gerando as rotas que percorri nessa busca (diga-se de passagem, inacabada) e do que me causa como potência, justificando todo o investimento. Além disso, há a identificação com um teatro que é feito à margem, sem visibilidade ou apoio.

É pertinente avisar ainda sobre uma graduação em Letras entremeio à formação teatral e uma característica "tripolar" entre o rigor da escrita, a pretensão teórica e a vontade de ser artista. 


\section{INTRODUÇÃO}

Julia Varley (1953), atriz do Odin Teatret, em um texto de Doña Música - personagem que nasceu na peça Kaosmos (1993) e se desenvolveu em um trabalho solo posterior - fala sobre a Teoria do Caos na qual, ao bater as asas em um recanto do mundo, uma borboleta pode causar uma tempestade ou um furacão em outro lugar distante da origem do estímulo original. ${ }^{1}$ Levada pela curiosidade sobre o que lia a respeito da Antropologia Teatral e por experiências com discípulos ${ }^{2}$, o vórtice que me assolava levou-me a procurar as borboletas, fontes vivas dos turbilhões que me atingiam.

Para falar dos procedimentos ${ }^{3}$ adotados na aquisição da presença e criação cênica a partir da tradição dos atores e do diretor Eugenio Barba (1936) do Odin Teatret esta dissertação debruçou-se sobre suas práticas entremeadas por seus escritos. As minhas participações como atriz e pesquisadora em oficinas ministradas sob a ótica da Antropologia Teatral por Barba e atores do grupo, no Brasil e na Dinamarca, ${ }^{4}$ muniram a pesquisa de elementos esclarecedores sobre como trabalham e aplicam os conceitos desse campo de

\footnotetext{
1 "Las teorías sobre el caos dicen que uma mariposa abre las alas em Honolulu y la consequência es uma tempestade em Laponia." VARLEY, Al vento do oeste - novela de un personage. Holstebro: Odin Teatrets Forlag, 1997, p. 29. E "Se lo llama 'efecto mariposa': um aleteo de mariposa em Japon provoca um huracán em Dinamarca.” VARLEY, Doña Musica's Butterflies - programa do espetáculo. Texto do espetáculo, XI. s/d, s/p. Traduções para o espanhol de Rina Skeel.
}

${ }^{2}$ Em 2002, cursei um workshop promovido pelo ator/diretor Gonzaga Pedrosa que acabara de voltar de cursos no continente europeu. Entre sua formação, a experiência que passou no Odin Teatret ajudou a configurar uma metodologia de trabalho que gerou profunda identificação em mim. Tomei parte, então, do grupo de pesquisa Teatro do Impulso com esse diretor até 2004, com retomadas de treinamento e colaboração em cursos ministrados até 2010. A partir dessa experiência, busquei aproximação com o grupo instalado em solo dinamarquês, perseguindo o entendimento do que me gerava tanta potência. Ainda, um curso no Lume - grupo teatral sediado em Campinas, São Paulo, herdeiro de ensinamentos do Odin Teatret, entre outras influências com o Prof. Dr. Renato Ferracini, em 2009, instigou ainda mais o interesse sobre o trabalho do grupo.

${ }^{3}$ A palavra procedimento é tomada por sua significação associada a aspectos de uma técnica que contém modos de agir, segundo consultas em dicionários de português.

${ }^{4}$ Oficina A Arte Secreta do Ator - Brasil: Como pensar através de ações. Idealização: Luciana Martuchelli e Eugenio Barba. Realização: Cia Ynspiração e Tao Filmes, Brasília, dezembro de 2009, 2010, 2011 e 2012. Odin Week, Holstebro, Dinamarca, agosto de 2013 (viagem realizada com o apoio a estudantes concedido pelo Projeto Auxílio a viagens da Pró-reitoria da USP). Oficinas com integrantes do Odin Teatret, em São Paulo: Roberta Carreri (21 a 25/01 de 2013; 8 a 10/11de 2013), Julia Varley (30/11 a 02/12 de 2013), promovidas pela Cia Mundu Rodá - Teatro Físico e Dança, e Jan Ferslev (23 a 28/10 2013), promovida pela Prof. ${ }^{a}$ Dr. ${ }^{a}$ Elizabeth Lopes, ECA-USP, São Paulo. Na fase final da pesquisa (junho/2014), viajei novamente para Holstebro como parte do que Barba chama de "o povo secreto do Odin" - pesquisadores teóricos e práticos do mundo inteiro que têm o grupo como tema - para acompanhar o Festuge comemorativo dos cinquenta anos de existência do Odin Teatret. Essa experiência não será detalhada na presente dissertação, mas há explicações sobre o evento em geral e, ao longo do texto, alguns apontamentos específicos sobre a experiência. 
estudo, provenientes da própria prática, tão bem documentados na vasta literatura do diretor e estudiosos correlatos. Da mesma forma, o contato com as atrizes e os atores do Odin Teatret propiciou as confluências entre o vocabulário técnico e prático difundido por Barba e, sobretudo, como atualmente transmitem suas tradições. Há um grande reconhecimento em torno de Barba por sua capacidade de comunicação oral e escrita das formulações sobre o ofício. No entanto, ele e todos os componentes do Odin Teatret têm pleno discernimento de suas especificidades e importância na manutenção dos cinquenta anos do grupo. A autonomia de seus atores se traduz também nas produções escritas de cada um, a quantidade de workshops que ministram pelo mundo e o reconhecimento de suas tradições. Mas às vezes, como Barba (2006, p. 20) salienta em relação aos colaboradores de Grotowski: “[...] a tensão coletiva, a criatividade de um grupo, a simbiose criativa de algumas pessoas, vêm resumidas em um único nome", é comum que, em um primeiro momento, os aspectos ligados à Antropologia Teatral estejam principalmente vinculados ao diretor. Ao longo desta pesquisa o contato com Barba, seus escritos e, da mesma forma, com os atores e suas aplicações/formulações, foram se equiparando no desvendamento do que foi/é o trabalho coletivo/individual deste grupo que se configura como um dos ícones do teatro mundial. ${ }^{5}$

Assim, o projeto $^{6}$ de um trabalho teórico-prático visando à autonomia no desenvolvimento pré-expressivo e processo de criação do ator/bailarino revelou-se, principalmente, no registro das experiências junto aos mestres, na realização do treinamento individual e coletivo, na aplicação pedagógica junto a grupos de atores e, concomitantemente, em um processo de criação, que ganhou, ao seu longo, ênfase na seleção e organização de materiais para a dramaturgia da atriz-pesquisadora e em um dos princípios estudados, sendo ele a omissão, também chamado de redução ${ }^{7}$.

A palavra "crônica", presente no título deste trabalho, remete tanto ao gênero literário, ao abarcar a experiência cronológica dos anos seguindo o trabalho do Odin Teatret e tratar do

${ }^{5}$ Diz Ferdinando Taviani (apud SCHINNO, 2012, p. 128; p.157), estudioso de teatro e conselheiro literário do Odin Teatret desde 1973: "O Nordisk Teaterlaboratorium/OdinTeatret é hoje uma pequena instituição cultural dinamarquesa, embora seja conhecida em todo o mundo. Tem uma situação financeira saudável - sólida como os orçamentos de todos os teatros [...]: sempre apenas sem dívidas e à beira do precipício."

${ }^{6} \mathrm{O}$ projeto de pesquisa aprovado previa um entrecruzamento entre as práticas da dança teatral e os princípios da Antropologia Teatral. Porém, ao longo da coleta e reunião de dados, a vivência com membros do Odin Teatret suplantou qualquer fonte da primeira, sendo, então, à sensível conselho de minha orientadora, o foco desta dissertação.

\footnotetext{
${ }^{7}$ Ver p. 67 deste trabalho.
} 
relato a esse respeito, quanto à acepção tomada no último espetáculo do grupo, $A$ Vida Crônica, ${ }^{8}$ no qual a necessidade guia uma busca permanente, quase doentia, por algo impalpável como uma resposta à inelutável morte.

Sem congelar as possibilidades em método, a aproximação aos conceitos e práticas do Odin Teatret investiga a conquista do domínio cênico através da presença física dilatada, amparada pelas citadas vivências com seus fundadores e a aplicação contemporânea de sua pedagogia. A identificação de parâmetros, ao invés de restringir, amplia as perspectivas de investigação e entrecruzamento das informações. Mais do que descrever uma forma de fazer ou adotar fórmulas para o ofício do ator, a documentação pormenorizada das pedagogias organiza ações permeáveis e intercambiáveis em favor da autonomia do intérprete na conquista de materiais criados a partir do corpo, buscando a efetividade de responder e se relacionar com impulsos orgânicos em cena. O levantamento de procedimentos ilumina o emprego de técnicas do ofício segundo a perspectiva apontada por Barba e seus atores, assim como a apropriação do que pode servir ao treinamento do ator e ao produto espetacular. Ao tomar os procedimentos práticos de uma tradição como pontes do fazer e, ao mesmo tempo, resumi-los, (re)ordená-los, compará-los, classificá-los, na descoberta de caminhos para utilizá-los cenicamente, tangemos também a exploração dos conceitos sobre presença cênica e discussões a respeito do que está decodificado sob a dilatada materialidade do ator em cena.

$\mathrm{Na}$ escolha de "ir atrás das borboletas", colocando-me em campo como experimentadora e observadora - vivendo e testemunhando as aplicações - em dialética com o material bibliográfico, os aspectos norteadores da pesquisa se pronunciaram. A partir de pressupostos da pesquisa qualitativa e da Pesquisa em Arte $^{9}$, as possibilidades de construir o método durante o percurso do trabalho estavam abertas. Nesse desenvolvimento adotamos a indicação da metodologia autoetnográfica ${ }^{10}$ a fim de valorar a experiência da perspectiva do sujeito e os instrumentos que já vinham sendo utilizados como entrevistas semi-

\footnotetext{
${ }^{8}$ Explica Barba que esse título foi tirado de um poema de Paulo Leminski, descoberto durante a degustação de um vinho uruguaio junto a Aderbal Freire Filho (Programa da peça, 2011, p. 9).

${ }^{9}$ Que considera o caminho, ilustrado pelo ininterrupto passeio entre interior e exterior, estabelecendo, um espaço de comunicação (REY, 2002, p. 126).

10 No exame de qualificação, etapa obrigatória deste trabalho, contamos com esse apontamento de via metodológica pela Prof. ${ }^{a}$ Dr. ${ }^{a}$ Marília Velardi (USP), adotado a partir daí. Contamos ainda com as formulações da Prof. ${ }^{a}$ Dr. ${ }^{a}$ Verônica Fabrini (UNICAMP) que também indicaram o caminho da referência de quem estava falando e contribuíram, entre outros, nos aspectos críticos em relação à Antropologia Teatral.
} 
estruturadas $^{11}$, observação-participante para coleta de dados e experimentação dos procedimentos aplicados pelos atores do Odin Teatret sobre as práticas pré-expressivas e o consequente relato de experiência seguindo parâmetros descritivos e analíticos, bem como a realização de treinamentos em laboratórios cênicos ${ }^{12}$, além de aplicações pedagógicas em $\operatorname{aulas}^{13}$.

Daniela Versiani (2005, p.172) traz subsídios para sopesarmos a adoção daquela perspectiva metodológica:

Processo de construção do conhecimento em que o pesquisador não se exime do fato de pertencer ao "objeto" que investiga, de considerar-se imerso nele, colocando lado a lado, tanto sua experiência pessoal e profissional quanto suas perspectivas teóricocríticas como forças motrizes de suas indagações e da escolha de seus objetos de pesquisa.

A autoetnografia mostrou-se, portanto, uma via de organização coerente do material, uma vez que a pesquisa tomou corpo justamente na documentação do que foi vivido, registrado e discorrido sobre o fenômeno, conectando o pessoal à experiência e sem a ambição de formular "verdades universais" nem esgotar os conceitos sobre o assunto tratado.

A atriz e antropóloga Adriana Dantas de Mariz, em seu livro A ostra e a pérola, ${ }^{14}$ destaca a visão do antropólogo Clliford Geertz (1973, apud MARIZ, 2007, p. xxiv) “Aquilo

${ }^{11}$ Organizar as entrevistas "cientificamente" foi um grande desafio. Elas foram gravadas em vídeo e/ou recursos de computador e/ou telefone celular. Alguns dos atores do Odin Teatret aceitaram ter sua imagem registrada, outros não. A única atriz que não consegui entrevistar foi Iben Nagel Rasmussen. Muitas vezes, as conversas com os atores e atrizes seguiram rumos inesperados e se deram em situações inusitadas, entre brechas de agenda, como quando, à sua procura durante a Odin Week - 2013, encontrei Tage Larsen com o prato de almoço na mão, situação na qual ele, gentilmente, achou que seria um bom momento para atender à minha solicitação. Ainda, as conversas sobre o ofício do ator se deram em várias línguas: inglês, português, espanhol e uma mistura entre elas. As risadas, as subjetividades de um entendimento tácito, um interesse comum ou a eventual incompreensão, conduzindo a outros entendimentos sobre o que estava sendo perguntado, não são passíveis de transcrição. Apoio-me em BAUER, M.W e GASLELL, G. Pesquisa qualitativa com texto, imagem e som (2002) para dar os parâmetros aos conteúdos das entrevistas, considerando intuições e traduções que podem melhorar "a qualidade de um delineamento de um levantamento e de sua interpretação" (p. 65). Assim, as falas têm seus deslocamentos visando o contexto desta pesquisa, pois "[...] o objetivo da pesquisa qualitativa é apresentar uma amostra do espectro dos pontos de vista." (p. 70).

${ }^{12}$ Segundo Mirella Schino, em Alquimistas do palco: os laboratórios teatrais na Europa (2009, vii), o conceito de laboratório teatral está associado à pesquisa artística e pedagógica, não vinculada necessariamente aos resultados da encenação, realizada por Stanislavski em seus Estúdios e adotada por seus sucessores.

${ }^{13}$ As aplicações de treinamento serão referidas no Capítulo IV.

${ }^{14}$ Que traz, como bem diz seu subtítulo, "uma visão antropológica do corpo no teatro de pesquisa", e cujo foco recai sobre os procedimentos de Barba e atores, entre outras fontes, como o trabalho do Centro de Pesquisa Teatral (CPT) liderado por Antunes Filho, em São Paulo. Mariz teve experiências de campo com o trabalho aplicado por Barba e atores na edição da Escola Internacional de Antropologia Teatral (ISTA- Londrina, 1994) e acompanhou diversas apresentações e palestras posteriores pelo Brasil (2008, p. xxix-xxxi). 
que chamamos de nossos dados, diz ele, são, na realidade, nossa própria construção a respeito das construções de outras pessoas. [...] portanto, 'toda etnografia é em parte filosofia e em parte confissão'." Neste aspecto, a confissão fica expressa pela admiração ao rigor, à coerência e resistência do grupo, e, ao mesmo tempo, por uma ternura umbilical ao que reconheço como possível no fazer teatral, envolvendo pedagogia, cena e relações.

Apesar da opção pela "tomada de rédeas" sobre a responsabilidade da enunciação (eu), o "nós" muitas vezes é utilizado, pois também é reconhecida a participação da fala de outros e suas colaborações. Bem como a polifonia que a atriz-criadora-pesquisadora-autora admite em seus vários "eus" fazendo parte de "um corpo só”. Em um corpo só também há o desejo de teoria e prática entrecruzadas, permitindo uma construção simultânea de conhecimentos - que, idealmente, se contaminam e entrelaçam - e pode ser criativa e artística.

$\mathrm{Na}$ fricção com um assunto amplamente abordado como é a Antropologia Teatral o recorte privilegiou as fontes primárias, ou seja, as falas presenciadas e escritos de Barba e de seus atores, e a bibliografia original de antecessores, principalmente Konstantin Stanislavski (1863-1938) e Jerzy Grotowski (1933-1999) sendo, porém, impossível deixar de citar Vsevolod Emilevich Meyerhold ${ }^{15}$ (1874-1940), Étienne Decroux (1898-1991), entre outros, que se fazem presentes também nos discursos de Barba. Estudiosos da Antropologia Teatral, bem como seus críticos, são citados pontualmente. ${ }^{16}$ Reconhecemos que é impossível dar conta de tudo o que foi já escrito sobre o Odin Teatret e, ainda mais, a respeito sobre metodologias para o ator. Focamos então nas tradições estudadas e recorremos a alguns pesquisadores que têm trabalhos elaborados sobre presença e treinamento do ator, devidamente referenciados em suas contribuições, sempre que ocorrerem. Ainda, flertamos com alguns conceitos de Martin Heidegger (1889-1976) e Hans Ulrich Gumbrecht (1948), pontualmente no Capítulo II.

\footnotetext{
15 A grafia do nome Meyerhold aparece desta forma ou como Meierhold, dependendo do autor que o cita. Optamos por manter a primeira em nossa escrita, respeitando a forma utilizada nas citações diretas. O mesmo acontece com Grotowski/Grotóvski.

${ }^{16}$ Entre eles De Marinis, Lluis Masgrau, Ian Watson, Nando Taviani, Patrice Pavis, Richard Schechner. As obras e datas referentes a esses e outros estudiosos aparecerão em suas respectivas referências nas citações utilizadas. Mateo Bonfitto e Renato Ferracini também configuram fontes.
} 
$\mathrm{Na}$ área de concentração em que a pesquisa está inserida, de teoria e prática teatral, há a proposição de um pesquisador-artista ser capaz de trafegar entre criação e reflexão. ${ }^{17} \mathrm{O}$ fazer falando sobre o que se faz, a verticalização sobre o objeto - que sempre abre janelas - a dicotomia entre teoria e prática e a busca do "entre" as duas, junto à adequação ao formato acadêmico da escrita foram exercícios neste percurso, influenciando, inclusive, a configuração da composição cênica que apresento.

É claro que há fatores de identificação com a linguagem desenvolvida pelo Odin Teatret e a forma de adquiri-la que norteiam a vontade de seguir os procedimentos e os testar. A personalização sempre é o próximo passo nessa linha de trabalho. Porém, não deixa de ser notório que a via da fisicalidade adotada pelo grupo é, há muito tempo, um dos caminhos mais efetivos na formação de estratégias de criação para o ator. As operações ${ }^{18}$ não são paradigmas imutáveis, mas antes, pontos de partida e, ao mesmo tempo, aplicações práticas que conduzem a outras operações e se transformam em estratégias para a lapidação do corpo e voz do ator. Estão ligadas também à composição dos materiais oriundos de improvisações ${ }^{19} \mathrm{a}$ partir de elementos internos e/ou externos. Mas podemos considerar que as operações são sempre transitórias, apesar de repetíveis, dentro de estratégias ${ }^{20}$ que visam à eficiência, isto é, a capacidade de se estar vivo em cena.

\footnotetext{
17 "Pensando as pesquisas prática e teórica como formas complementares de produção de conhecimento; nesta área surgem associadas às figuras do teórico, do crítico, do hermeneuta e do criador teatral no próprio pesquisador, que, a exemplo do artista-pesquisador contemporâneo, trafega pelas várias ordens de operação teatral. Ao estimular a produção conjunta de conhecimento e prática do teatro, a proposta desfaz o esquema baseado na dissociação temporal das operações criativa e reflexiva. Ambas são exercitadas conjuntamente, questionam-se e se complementam, já que a prática vem sustentada pela reflexão teórica e a teoria é necessariamente uma práxis de teatro.” Ementa da área de concentração e linha de pesquisa do Programa de Pósgraduação em Artes Cênicas (PPGAC), disponível em:

<http://www3.eca.usp.br/pos/ppgac/apresentacao/organizacao-das-linhas-de-pesquisa>. Acesso em: 08/06/2013.

${ }^{18}$ Consultando dicionários, achamos que a palavra operação, entre seus significados, diz respeito ao conjunto de meios combinados para se obter um resultado e a um agente ou poder que opera, ou seja, trabalha para que ela aconteça, ao mesmo tempo que trabalha sobre ela. Estratégia, como referida no texto anteriormente, está ligada à técnica, ao método, mas também à trama, habilidade e sagacidade.
}

19 Explica Varley (2010, p. 96) “A improvisação é geralmente caracterizada por um fluxo ininterrupto de reações. A dificuldade reside em reconstruí-la nos mínimos detalhes. A composição, ao contrário, é o processo de juntar um detalhe a cada vez, concentrando-me, passo a passo, em diferentes partes do corpo, em diversas imagens, decidindo a sucessão de (sic) forma que meu corpo assume em relação ao ponto de partida. Os elementos criados são unidos e montados, tornando-se 'materiais'." Barba (2010b, p. 62) salienta três procedimentos em relação à improvisação: a) criação de materiais partindo de várias fontes; b) como sinônimo de variação sobre materiais já assimilados criando significados diferentes; c) individuação e capacidade de repetir a mesma partitura com nuances diferentes.

${ }^{20}$ Em tempo, o uso dos termos "operações e estratégias" foi inspirado em abordagens propostas pela Prof. ${ }^{\text {a }}$ Dr. ${ }^{\text {a }}$ Maria Thaís em sua disciplina Da pedagogia à cena (C. Stanislavski - J. Grotowski), da Cena à Pedagogia (V. Meierhold - T. Kantor): Perspectivas, Heranças e Fricções, cursada na ECA-USP em 2012, para o estudo dos textos dos respectivos autores. Varley (2010, p. 100), por sua vez, fala em "estratégias e procedimentos". 
Detalhando a divisão dos assuntos, no Capítulo I, os "filtros de organização" (1.1) são apresentados e contemplam o aprofundamento sobre a metodologia adotada e o que chamamos de "noções basilares", abarcando termos e vias de utilização de conceitos a fim de evidenciar as escolhas de condução da pesquisa. Em seguida, abordamos os fundamentos da Antropologia Teatral (1.2) em seus aspectos históricos e pressupostos inaugurais como campo de pesquisa do fazer cênico bem como aspectos controversos de suas postulações. Nesse capítulo, sentimos necessidade de registrar uma breve biografia dos atores atuais do Odin Teatret (1.2.1), que serão citados muitas vezes ao longo das páginas deste trabalho, traçando um panorama inicial de seus papéis no grupo e amparando as tradições consideradas no Capítulo III. O Capítulo I segue com a descrição da experiência n'A Arte Secreta do AtorBrasil, em workshops ${ }^{21}$ sucessivos, de 2009 a 2012, com Eugenio Barba e Julia Varley, vivenciados em Brasília, principalmente do ponto de vista da pedagogia da transmissão e aplicação de conceitos desenvolvidos no Odin Teatret sobre o trabalho do ator (1.3). Também há o registro sobre a experiência no Odin Week Festival ${ }^{22}$ (1.4), no qual pude entrar em contato presencial com a tradição de outros atores do grupo, fato que ampliou a abordagem da aplicação técnica do treinamento, possibilitou assistir ao repertório de espetáculos ativos, delineando ainda mais o entendimento do uso criativo, e permitiu estar no local histórico dos acontecimentos, gerando o aprofundamento da visão sobre as noções éticas e estéticas do grupo.

A incorporação prática dos procedimentos identificados em campo alicerçou pontes de entendimento entre estudos sobre presença cênica e treinamento, conduzindo à abordagem do Capítulo II. Chamado de $O$ desvelamento do Ser-ator este capítulo empresta o conceito de Heidegger para sua abertura e introdução aos desenvolvimentos de Gumbrecht, apresentados em seu livro Produção de Presença (2010). Nesse, o autor salienta as características da hermenêutica $^{23}$ na cultura ocidental como uma perda da materialidade, da coisa em si, que ${ }^{21}$ O termo workshop é adotado como sinônimo de curso e oficina, todos usados várias vezes no decorrer da
dissertação para referências às experiências pedagógicas compartilhadas.

22 A Odin Week, realizada uma vez por ano no Odin Teatret em Holstebro, Dinamarca, é um festival internacional teórico-prático que inclui treinamento, apresentações do repertório do grupo, demonstrações de trabalho, filmes, reuniões com Eugenio Barba, palestras e discussões. Disponível em: <http://www.odinteatret.dk/workshops/odin-week-festival.aspx>. Acesso em: 02/12/2013. Quando usarmos o nome do curso sem seu prenúncio, Festival, tratá-lo-emos no feminino, pensando em sua tradução: semana Odin.

${ }^{23}$ Gumbrecht aponta que esse se tornou o nome de um subcampo da filosofia "que se concentra nas técnicas e condições da interpretação" (2010, p.50). Porém salienta que o paradigma da identificação e atribuição de sentido tornou-se predominante na cultura ocidental antes do surgimento dessa nomenclatura, ocorrendo na passagem do mundo medieval para o mundo moderno, quando as dicotomias entre mente e corpo foram 
servem aqui para discutir algumas questões sobre materialidade e sentido, abrangendo as noções de dramaturgia que Barba apresenta e tangendo o aspecto de recepção na relação com os espectadores (2.1). Em uma abordagem metonímica, partimos desses pressupostos gerais para as noções sobre presença cênica (2.2) com o intuito de delinear a sua significação no trabalho do ator. Encadeamos, então, o diálogo dos conceitos apresentados com noções sobre a aquisição técnica da presença (2.2.1), visitando mais profundamente a árvore genealógica da qual Barba se origina, trazendo Stanislavski e Grotowski, além de outros encenadores e pedagogos do século XX. Busca-se assim, rastrear os procedimentos desenvolvidos no Odin Teatret a fim de munir o ator com recursos que o habilitam a atingir o corpo extra-cotidiano, que o dilata em cena. Isso nos leva ao tema do treinamento em si (2.2.2) nas abordagens sobre de que se trata e para o que serve ao ator. O capítulo ainda contempla uma breve consideração sobre as técnicas somáticas que podem ajudar o ator no aprimoramento de sua percepção sobre si mesmo (2.3). Em tópicos diferentes, ao longo do capítulo, destacam-se algumas referências como Patrice Pavis, Richard Schechner, Ian Watson, Mateo Bonfitto e Renato Ferracini, além das visões de Barba e seus atores sobre os assuntos.

No terceiro capítulo, Tradições documentadas, são descritos os procedimentos registrados nos workshops com atores do Odin Teatret, detalhando cada tradição contida no que chamamos de "o estado da técnica" (3.1) salientando os aspectos técnicos da preparação pré-expressiva, ou seja, o treinamento desenvolvido por cada um. "Estados de arte" (3.2) trata da dramaturgia do ator, abordando as noções sobre partitura, subpartitura e composições dos atores do Odin Teatret em improvisações e montagens presenciadas em suas demonstrações de trabalho. Portanto, são listados e descritos os exercícios vivenciados e observados, bem como as lógicas pessoais nas encadeações em composições cênicas, com ênfase nos trabalhos de Varley e Carreri, notando que "Toda descrição é, de fato, uma interpretação no sentido de que é a seleção de informações e atribuição de significações a partir de uma memória e de um imaginário individual e coletivo.” (FORTIN, 2009, p. 82).

ganhando destaque, culminando com o cogito de Descartes (p. 56) e ressonando nas postulações posteriores até o mundo pós-moderno.

24 A Odin Week de 2014 foi disponibilizada ao vivo e permanece on-line no endereço eletrônico: <http://new.livestream.com/OdinTeatretLiveStreaming/Odinweek2014/videos/60565420>. Essa novidade possibilita uma referência direta a alguns dos exercícios descritos no Capítulo III ministrados pelos mestres atores do Odin Teatret, e também aos encontros com o diretor do grupo, junto aos participantes desse evento. Acesso em: 20/08/2014. 
Essa memória está documentada em vários "diários de bordo" 25 sobre as vivências. A descrição de exercícios e formas da preparação pré-expressiva do ator, assim como a lógica de composição dramatúrgica, além de documentar a aplicação das tradições, conforme experimentadas de 2009 a 2014, espera se revelar em sua materialidade, ou seja, em ações concretas com resultados visíveis na preparação corporal/vocal e no exercício de composição cênica, nos treinamentos aplicados e possíveis reaplicações/reinterpretações por leitores/atores/pesquisadores. A fim de também materializar as informações anotadas, acompanha o texto um DVD com fragmentos do treino pessoal e da cena, sendo, os dois últimos, o mote para o próximo capítulo.

O capítulo quarto trata da documentação do meu percurso como artista-pesquisadora e pedagoga, considerando a aplicação do treinamento individual e em grupos e procedimentos de composição e montagem cênica. Entre o que é ínfimo (o muito pequeno) e o inexorável (que não tem piedade, que é rigoroso, do que não se pode escapar), ${ }^{26} \mathrm{o}$ olhar se volta para $\mathrm{o}$ exame do entendimento e busca da construção personalizada de cada estímulo. O processo de criação cênica refletiu a necessidade de organização de desejos, recortes de imagens e textos coletados nos vários diários ${ }^{27}$ e articulados na dramaturgia pessoal salientando a necessidade de escolhas e seleção de materiais. Apresento a escrita sobre a composição cênica como notação do fluxo de criação na perspectiva da dramaturgia do ator, tornando o próprio registro retrato do acontecimento, conforme se deu. O "resultado" não é um produto cênico finalizado, sendo proposta uma demonstração de trabalho em processo que evidencia a seleção dos materiais e sua composição.

Seguem-se as considerações finais e os elementos pós-textuais, como apêndices e anexos, que contém excertos dos documentos de cursos junto a Barba e atores.

\footnotetext{
${ }^{25}$ Chamarei de diário de bordo ou de trabalho os meus cadernos de anotação. Fortin traz outras nomeações e sua função: "Seu relatório de bordo, crônica da ação ou carnê de prática (diferentes apelações são utilizadas de maneira quase intercambiável) compreende evidentemente a descrição dos gestos e palavras dos protagonistas do estudo, mas também as análises espontâneas ou intuições que poderiam surgir no calor da ação.” (2009, p. 80) Disponível em: <http://seer.ufrgs.br/index.php/cena/article/view/11961/7154>. Acesso em 12/11/2013.

26 "Entre o ínfimo e o inexorável" foram palavras de Pina Bausch em entrevista sobre o processo de montagem de Bandoneon. Bandoneon em Buenos Aires. Vídeo Instituto Goethe, s/d. Anotação pessoal em aula da disciplina ministrada pela Prof. ${ }^{a}$ Dr. ${ }^{a}$ Sayonara Pereira, USP-ECA, 2012.

${ }^{27}$ A professora e atriz costa-riquenha Tatiana Sobrado em sua pesquisa de doutoramento, Voz no corpo gritante: os desafios do processo solo de ator, defendida no primeiro semestre de 2014, na Universidade de São Paulo, salienta o uso da escrita em diários como prática recorrente de artistas do teatro, inclusive pelos atores do Odin Teatret. Ela toma a perspectiva Cecília Salles que "considera os diários de artista como documentos de processo, dispositivos que carregam as pegadas da jornada de construção da obra." (SOBRADO, 2014, p.169.) Inédito.
} 
A pesquisa delineou as técnicas pessoais de atores do Odin Teatret e indicou a personalização do treinamento. Revisitou a história do desenvolvimento dessa abordagem de preparação técnica levando em conta as tradições de encenadores e pedagogos do século XX. Não se pretende provar que este é o caminho certo para o desenvolvimento do ator em todo o caso, mas se admite o resultado material no qual se apresenta (seja neste texto ou na cena). Considerando as impossibilidades de se obter um "sentido" único e fechado sobre o ofício do ator, as questões, na medida em que não alcançam respostas decisivas e permanentes, evidenciam, por si, que o assunto, apesar de tão explorado, não obtém um caráter conclusivo e finalizado, justificando a contínua investigação e interesse pelo tema. Atuam, então, como provocadoras de ações e formulações, na realização de uma pesquisa que, de forma cíclica, mas espiral, retoma tradições, conta-as, procura entender e aplicar os pressupostos do trabalho do ator sobre si mesmo e, ao mesmo tempo, realizar um experimento cênico. 


\section{CAPÍTULO I}

\section{ESTRUTURA, HISTÓRIA E VIVÊNCIA}

\subsection{Filtros de organização: bricolagem metodológica e noções basilares}

“[...] pesquisa significa diálogo crítico e criativo com a realidade, culminando na elaboração própria e na capacidade de intervenção. Em tese, pesquisa é a atitude do 'apreender a apreender', e, como tal, faz parte de todo processo educativo e emancipatório."

Pedro Demo, 1993, p.80.

"Todo termo deslocado desloca com ele o edifício inteiro."

Patrice Pavis, 2010, XIII.

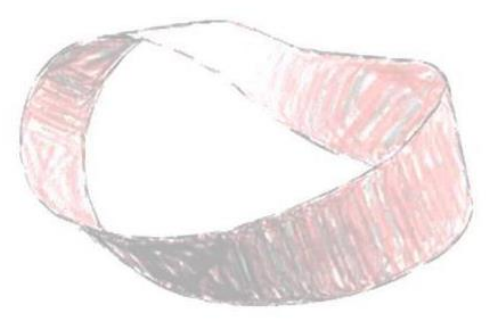

Figura 1. Fita de Mobius. Manipulação digital: Leticia Olivares.

A abordagem desta pesquisa, como já assinalado, é de caráter principalmente qualitativo e sua metodologia revelou-se no fazer, tomando os pressupostos da "pesquisa em arte", que aponta um caminho ilustrado pelo ininterrupto passeio entre interior e exterior, como no espaço contínuo da fita de Mobius $^{28}$, em um tempo sem limites ${ }^{29}$ (REY, 2002, p. 126). A identificação da pesquisa sobre o ofício teatral com o símbolo do infinito que a fita pode assumir e sua recorrência entre dentro e fora é oportuna. Casa-se com o fundamento de

\footnotetext{
${ }^{28}$ A fita de Mobius é uma superfície topológica não-orientável estudada pelo astrônomo e matemático Augustus Ferdinand Möebius (1790-1868).

${ }^{29}$ Este não é propriamente o caso de uma dissertação, que tem limite de tempo para ser apresentada, cumprindo uma agenda acadêmica pré-estabelecida. No entanto, consideramos que o texto final, apresentado dentro deste limite, é apenas uma passagem na organização de um conhecimento que não se encerra em si mesmo, mas antes, continua a ser uma procura pelo próprio conhecimento sobre o que se está falando, já que tem relação ininterrupta com o que se está fazendo.
} 
Stanislavski sobre o trabalho sobre si mesmo para o ator. ${ }^{30}$ Trabalho que não tem fim, mas uma disposição para continuar e "aprender a aprender", sublinhada por Barba (2009, p. 26; 2012, p. 13) como prerrogativa para o domínio do próprio saber.

Durante a dissertação, comprova-se essa trajetória da relação teoria-prática na qual recorro a vivências que datam de vários anos à dedicação ao fazer teatral até o presente e à pesquisa de conceitos, fundados em uma tradição delineada historicamente, sobre esse fazer. É um percurso que se revela nos deslocamentos físicos até os campos de pesquisa, na revisão bibliográfica e videográfica dos e sobre os objetos pesquisados, nas consultas aos diários de trabalho, em ambientes de ensino e aprendizagem, como aulas ministradas e oficinas cursadas, na experimentação individual e coletiva de treinamentos e em laboratórios de criação. ${ }^{31}$ Essas relações retroalimentam-se e se revisitam, contaminadas o tempo todo em um colóquio dialético do percurso físico-analítico entre prática e teoria, que deflagra constatações sobre a aplicação da técnica em diálogo com os conceitos sobre a mesma.

Ainda visando à escolha do método adequado à situação e ao objeto de estudo, a opção pela realização de um experimento solo, chamado aqui de composição ${ }^{32}$ cênica, qualifica-se pela base empírica na formatação de resultados, encontra eco nas práticas metateatrais da pós-modernidade (DIP, 2005, p. 127), através das quais o diálogo entre autorintérprete $^{33}$-criador possibilita uma maior apropriação sobre o processo de elaboração e responsabilidade pelo resultado cênico, e diz respeito diretamente ao processo autônomo do ator na confecção de seus materiais, o que, por sua vez, não dispensa o olhar do Outro ${ }^{34}$.

\footnotetext{
${ }^{30} \mathrm{O}$ conceito aparece pela primeira vez como título de seu segundo livro O trabalho do ator sobre si mesmo no processo das vivências (1938-Rússia). No Brasil, foi traduzido a partir da edição estadunidense, como $A$ preparação do ator (1964). Cabe aqui ressaltar a revisão que vem sido feita das traduções brasileiras, por conta das supressões que as edições norte-americanas contêm. Anotação pessoal referente à disciplina Da pedagogia à cena [...], Prof. ${ }^{a}$ Dr. $^{a}$ Maria Thaís. ECA-USP, 2012.
}

${ }^{31}$ Durante a pesquisa, além de participar dos workshops junto ao Odin Teatret, ministrei aulas para alunos de graduação da USP (2013, 2014), apliquei o treinamento junto a Cia Magna Mater e ao Coletivo Rubro Obsceno $(2013,2014)$, dirigi uma peça teatral aplicando o treinamento e montando a dramaturgia final (2012; idem). Ver APENNDICE.

32 O termo composição como explicitado por Bonfitto, em o Ator-compositor (2009, xviii), é adotado por Meyerhold, Tchécov e Barba de forma literal para falar sobre o trabalho do ator.

33 Não faremos distinção entre o termo intérprete e ator, usando-os inclusive como sinônimos, à parte as discussões contemporâneas sobre suas diferenças.

${ }^{34} \mathrm{O}$ "Outro" tomado em sua capacidade de troca e agregação, qualidades essenciais no Teatro. Diz Grotowski (2011, p. 25) que o teatro existe pelos seus elementos essenciais: ator-espectador e o que acontece entre eles. Barba coloca que o diretor é o primeiro espectador, responsável por testar esse acontecimento e o aprimorar. Comentou, certa vez: "Pobre do ator que não encontra seu diretor." (Anotação pessoal, A Arte Secreta do Ator- 
Tomamos então as propostas etnográficas e autoetnográficas como via de confluência dos aspectos metodológicos acima citados. Segundo Sylvie Fortin,

\begin{abstract}
Os projetos de aprendizado da prática artística, quer se trate do seu ou de um outro artista, ocupam o studio, o atelier, a aula ou a comunidade. Considerando estes lugares como "campos da prática artística", a etnografia e a auto-etnografia (sic) podem, desde agora, ser consideradas como métodos de pesquisa podendo inspirar a "bricolagem" metodológica do pesquisador em prática artística. Por "bricolagem" metodológica,[...] eu entendo a integração dos elementos vindos dos horizontes múltiplos, o que está longe de ser um sincretismo efetuado simplesmente por comodidade. Os empréstimos são aqui pertinentemente integrados a uma finalidade particular que, muitas vezes, pelos pesquisadores em arte, toma a forma de uma análise reflexiva da prática de campo. (2009, p. 78)
\end{abstract}

Nesse aspecto, os instrumentos etnográficos evidenciam-se pelo trabalho de campo e entrevistas semi-estruturadas, e os dados autoetnográficos pelos procedimentos documentados e os materiais levantados. Essa abordagem se justifica também pelo reconhecimento do caráter evocativo ao dissertar sobre as vivências nos recantos visitados e anotações realizadas, nas quais a fala do Outro é então traduzida por minha própria experiência e modo de registro. Dessa forma, o relato de experiência dos quatro anos em que compareci aos workshops com Barba e Varley ${ }^{35}$, realizados em Brasília, bem como os cursos isolados com atores do Odin Teatret realizados no Brasil e, ainda, a documentação sobre a Odin Week, frequentada em agosto de 2013, em Holstebro, na Dinamarca, apresentam-se com considerações também às "reações somáticas do pesquisador como um tipo de dado etnográfico" (Frosch, 1999, apud FORTIN, 2009, p. 81), com o cuidado de que sirvam para apoiar a construção reflexiva sobre o processo. Nesse aspecto, as notas de rodapé muitas vezes assumem particular importância, trazendo a coexistência das dimensões de relações e percepções nas formulações sobre os acontecimentos.

Aponto uma questão de gênero que faz parte da nominação de "quem" está falando. Varley, nas falas e escritos, geralmente opta pelo termo "atriz" ao expor suas descobertas e metodologias, a fim de que, igualmente, a voz e a escrita proferida por mulheres fiquem

Brasil, Brasília, 2009). Muitas vezes senti na carne a falta do "diretor", aspirando até mesmo que houvesse alguém para me dizer o que fazer. Mas no caminho da "autonomia" de criação e montagem dos materiais, pude contar com outros olhares como o da orientadora Prof. ${ }^{a}$ Dr. ${ }^{a}$ Sayonara Pereira e, em dezembro de 2013, pontualmente em um encontro durante seu curso em São Paulo, com o de Julia Varley.

${ }^{35}$ No ano de 2012, comentei com Julia Varley sobre minha dificuldade em questionar os procedimentos, uma vez que me fazia um sentido "celular" o que propunham e o que eu experimentava ao fazer os exercícios, ressoando em meu corpo-mente como concordância, como um grande SIM. Seu conselho foi que então eu achasse as minhas próprias palavras na reescrita sobre o entendimento daquilo que diziam e faziam. 
registadas na história a partir do emprego do feminino. ${ }^{36}$ Quem aqui disserta também é uma mulher. No entanto, devido à característica de generalização atribuída à substantivação pelo masculino (e apesar de sua arbitrariedade), adoto-o para falar do trabalho do ator. Nessa decisão encontrei amparo na própria definição da Antropologia Teatral na qual, ao estabelecer seu campo de estudos no comportamento pré-expressivo encontrado em diferentes tradições cênicas pessoais e coletivas, há o apontamento “[...] lendo a palavra ator, se deverá entender 'ator e bailarino', seja mulher ou homem; [...]” (BARBA, 2009, p.25), salientando que não tocaremos especificamente na indistinção entre agentes do teatro e da dança sugerida no primeiro exemplo.

A palavra autonomia aparece várias vezes na pesquisa e merece considerações. Sob qual ótica a estamos tomando? Ao falar dos procedimentos do ator, tratamos de autonomia do quê? No caso do teatro e especificamente dos atores, quando se fala sobre autonomia encontramos as origens do ator-criador. Historicamente podemos tomar a conquista de estratégias que dizem respeito ao processo treinamento e criação do ator independentemente da encenação. Stanislavski, ao se perguntar onde residiam as características do talento de um ator, tentou decodificar o caminho em direção à verdade cênica, aos recursos possíveis para gerar a verossimilhança capaz de tornar crível o que se fazia em cena. Deu início a uma investigação sem fim dos procedimentos aplicáveis em busca do aprimoramento do ofício de ator. A pedagogia foi-se conformando em um Sistema para a formação do ator e grande ênfase começou ser dada à preparação corporal. Também Meyerhold, Antonin Artaud (18961948) e Grotowski, ${ }^{37}$ cada um à sua forma, apresentaram novas direções para o trabalho do ator baseadas, principalmente, na fisicalidade e presença. Vale ressaltar que Artaud não delineou nenhum método, mas, como ressalta Ferracini (1999, p.70), proclamava o teatro como uma arte livre e autônoma. E transformou o sentido do fazer teatral, insuflando o teatro a uma linguagem física capaz de mexer com as sensações dos espectadores, em uma criação total transgressiva, que possa ampliar os limites da arte. Mas a partir dos estudos do primeiro mestre russo, ou seja, Stanislavski, a linha de pesquisa instaurada buscou, no treinamento corporal e nas ações físicas, recursos para munir o ator de autonomia na preparação para seu trabalho. Nessa árvore com galhos distintos, pelo menos com relação à pedagogia e aplicação de treinamento aos atores, Barba é herdeiro da tradição direta de Grotowski, o que implica

\footnotetext{
${ }^{36}$ Cf. VARLEY, 2010, p. 25-31.

${ }^{37}$ Cf. Os pais mestres do ator-criador, de Renato Ferracini. in Revista do Lume, n.2, UNICAMP, Campinas S.P, 1999.
} 
também na herança stanislavskiana, e seguirá a linha da preparação corporal, tomando-a, ao mesmo tempo, como base para a criação e estabelecendo o procedimento de partituras físicas e vocais como um ponto de partida para o ator trazer o material que por ele, como diretor, será trabalhado na encenação.

Ao analisarmos o percurso dos atores do Odin Teatret o conceito de autonomia sempre esteve presente: "entre na sala e faça o seu treinamento; saiba ensinar o que você sabe" "38. Isso implica, nos atores pesquisados, formulações sobre o próprio fazer e a condição pedagógica que as tais assumem ao transmitir uma tradição. Na aquisição corporal dos modos de fazer ao longo do desenvolvimento de seu treinamento pessoal, o ator é fonte e recurso para seu próprio ofício. Grotowski já apontou essa via e, antes dele, Stanislavski, na vontade de libertar o ator da automação. O trabalho do ator sobre si mesmo implica a conquista da autonomia, o reconhecimento de sua capacidade para iniciar sua ação sem que lhe digam o que deve fazer. Isso envolve também o conhecimento sobre sua própria "corcunda psíquica” (GROTOWSKI, apud BARBA, 2006, p. 19) e o que dela fará criativamente através de seu corpo, desenvolvido em habilidades pelo treinamento, em condição de "laboratório" e refletido em cena. Barba (2010a, p. 42) dirá que a essência da expressão do ator e de sua metodologia se traduz em signos objetivos vistos pelos espectadores. Ainda, segundo ele, isso é fruto de um trabalho subjetivo em soluções pessoais que morrem com cada ator. ${ }^{39}$

Todavia o que nos prende para não sermos livres? Grotowski trabalhou justamente sobre o desbloqueio do corpo do ator, a fim de permiti-lo tirar os obstáculos e ser vivo em cena. É a sua "via negativa" que, muitas vezes, através da exaustão, visava à liberação de energias sutis, porém potentes, presas em condicionamentos mentais e corporais. Diz Grotowski:

Estamos sujeitos, consciente ou inconscientemente, a sofrer influências das tradições, da ciência, da arte e até mesmo das superstições e prevenções peculiares à civilização que nos moldou, assim como respiramos o ar do continente em que

\footnotetext{
${ }^{38}$ Anotação pessoal. A dança das intenções. Roberta Carreri, nov./2013. Isso, praticamente, fez com que todos desenvolvessem uma pedagogia desde muito cedo. Diz Carreri sobre o início do grupo: "Todos os dias, após sessões de treinamento conduzidas por Eugenio, [os atores] alternavam-se no papel de mestre e trocavam entre si suas habilidades. Aprendiam assim a transmitir a própria experiência.” (2011, p. 39). E sobre sua experiência, quando foi posta a ensinar: "Essa incumbência foi de importância capital na minha formação. [...] Ensinando eu me apropriava do meu conhecimento." (p. 41).

${ }^{39}$ Uma fala de Stanislavski (1997, p. 194) também trata desse aspecto: “Tudo o que fazem [os atores] morre com eles, mas seu legado de criatividade, tradições, crenças pelas quais foram inconscientemente guiados no início de suas carreiras artísticas, e que vieram a formular nos anos de sua maturidade, quando delas tomaram consciência, são coisas que ficam para a posteridade."
} 
nascemos. Tudo isso influencia nosso trabalho, embora às vezes a gente negue. (2011, p. 19)

As superstições são sempre salientadas por Barba ao nos apegarmos a certos paradigmas, que podem ser produtivos ou não, na nossa construção artística. Diz ele (2010b, p. 135 grifo do autor): "O uso do conhecimento ou de uma imagem é sempre determinado pelo sistema de pensamento e pelas superstições da pessoa que os escolhe, servindo-se de uma interpretação pessoal."

Nesse ponto é interessante destacar que apesar de todo o pragmatismo dos procedimentos e da abordagem sobre o ofício, Barba e os atores estão sempre conectados aos aspectos ritualísticos do teatro. Seja na repetição abnegada dos exercícios ou no esforço da transmissão do que sabem, seja nos espetáculos, o sagrado permeia a trajetória do grupo, em uma busca de transcendência que é motivada por desafios de sempre superar seus próprios limites, reinventar-se a cada atividade e ter em mente a pergunta com que Barba abre muitas de suas falas em palestras: "Por que fazemos teatro?" ${ }^{\circ 0}$ E essa é uma resposta que deve ser achada por cada um, pois as que serviram a eles talvez não sirvam a outros. Mas suas formulações a partir dessa pergunta inicial são inspiradoras. Sem diferenciar a transcendência vertical da horizontal, nas relações, reconhecimento e prazer, Barba (2010a, p. 23) interessase por continuar "na ponta dos pés" e debruçar-se por cima do muro "que nos protege e nos aprisiona". E, ainda, retomando a inquietação de Grotowski: “o que fazer do teatro?", sua resposta é que, apesar de ser uma arte irrisória, sem condições de mudar o mundo, é uma ilha de liberdade que tem dimensões sagradas, porque transforma o ser (BARBA, 2006, p. 192).

A palavra tradição, recorrente no vocabulário do grupo pesquisado, ${ }^{41}$ é tomada em relação às sistematizações de procedimentos, operações e estratégias para o ofício do ator, seja por antepassados ou contemporâneos, como é o caso dos atores do Odin Teatret. Stanislavski (1997, p.194) já notava que a "essência espiritual" das tradições dos atores é difícil de ser determinada, “pois, em geral, as realizações de uma vida são sintetizadas numa

\footnotetext{
${ }^{40}$ Entre minhas anotações pessoais achei os registos dessa pergunta em duas ocasiões: 19/08/2013, Odin Week, Holstebro, Dinamarca; 10/12/10, A Arte secreta do Ator - Brasil, Brasília. Na entrevista que realizei com Barba, em 2011, durante a terceira participação na Arte Secreta do Ator-Brasil, quando já se delineava o projeto desta pesquisa, contei para ele que eu, como artista e pesquisadora buscava minha "pergunta-esfinge", aquela que me seria primordial perscrutar a resposta infinitamente. E perguntei a ele qual era a sua. A resposta foi: "Porque faço teatro?".

${ }^{41} \mathrm{Na}$ Odin Week, por exemplo, faz parte da programação a apresentação das tradições de cada ator (com o nome no programa: Tradição Julia Varley, Tradição Roberta Carreri etc.) por meio de suas demonstrações de trabalho.
} 
fórmula concisa." Perante isso, como se organizam os deslocamentos das tradições? Barba reflete:

\begin{abstract}
O conceito de tradição é ambíguo; aparentemente se refere ao passado, na realidade é sempre uma criação retrospectiva: está constituída por homens e a história que deixamos atrás de nós, nos quais nos reconhecemos, dos quais nos separamos, aceitando e transformando sua herança. ${ }^{42}$
\end{abstract}

Ao falarmos de materiais estamos nos referindo, objetivamente - porém sem esquecer que as subjetividades fazem parte dessa construção - ao que se constitui como resultado das estratégias do ator na pesquisa e seleção do que lhe serve como aprimoramento técnico e do que estará em cena. Isso decorre, segundo essa linha de trabalho, do treinamento de princípios decodificados, a exercitar, no nível operador pré-expressivo, diversos procedimentos que envolvem, principalmente, testar no corpo estímulos para a improvisação e criação. Estes estímulos podem vir de fontes determinadas (uma imagem, uma música, uma frase ou texto pré-existente, exercícios específicos etc.) ou abstratas (uma preferência, superstição, inspiração ou outras) que possam ser materializadas em ação, criando as partituras corporais e vocais. Carreri aponta que foi no processo de O Evangelho de Oxyrhyncus, espetáculo de 1985, que o termo material, usado para designar "[...] todas as partituras fixas criadas de diversos modos", começou a fazer parte da linguagem de trabalho do grupo (2011, p. 135). Barba (2010b, p. 95) classifica os materiais cênicos como "o conjunto dos elementos criados pelo ator: sequências de ações físicas e vocais, propostas de textos, canções, figurinos, objetos." Essa conformação dos materiais nos leva ao esclarecimento do termo dramaturgia que é tomado por Barba $\left(2009\right.$, p. $\left.38^{43}\right)$ como um processo que não pertence somente à literatura dos textos dramáticos, mas como uma "operação técnica inerente à trama e ao crescimento de um espetáculo e de seus vários componentes." Nesta pesquisa os componentes da dramaturgia do ator, criada a partir do treinamento e da composição de seus materiais, têm foco principal.

\footnotetext{
${ }^{42}$ Tradução nossa. Original: "El concepto de 'tradición' es ambiguo; aparentemente se refiere al passado, en realidad siempre es una creación retrospectiva: está constituida por los hombres y por la historia que nos dejamos atrás, en los cuales nos reconocemos, de los quales nos apartamos, aceptando y transformando su herancia. BARBA, Eugenio. Barcos de piedra e islas flotantes. Revista Máscara, ano 4. No. 19-20 (Out-1994/1995). México: Escenologia, A.C. p. 5.

${ }^{43}$ Ver também BARBA \& SAVARESE, 2012, p. 66-68.
} 
Quando me refiro a "mestres" não pretendo somente prestar respeitosa deferência aos citados. $^{44}$ Levam-se em conta a experiência e os ensinamentos provindos dos mesmos, inclusive perante a ocupação de sua transmissão. Segundo Richard Sennett (2009, p.30) é corrente ser considerados mestres aqueles que possuem dez mil horas no ofício. Não é esse o caso. Eles/as ${ }^{45}$ possuem muito mais horas do que isso. Uma vida-arte, dedicada ao fazer/pensar sua ação no mundo, com a capacidade pedagógica movida pela crença empírica da realização.

Cientes das críticas que a adoção dos procedimentos herdados contém, posicionamonos sobre a percepção de que não se trata de submissão sem questionamentos a um eurocentrismo que é discutido como colonização às noções de que, sim, somos influenciados por noções externas que podem ser impostas. Antes (ou depois) há uma identificação com um fazer transcultural ${ }^{46}$ do ofício do ator em suas possíveis estratégias para alcançar a presença cênica, que está permeada pelo reconhecimento ${ }^{47}$ de quem veio antes na linha de pesquisa escolhida. Não há nada de inaugural ou original nesta pesquisa. Há a identificação e devida

\footnotetext{
${ }^{44}$ Falando em títulos, Barba recebeu vários de doutor honoris causa pelas universidades de Aarhus, Ayacucho, Bologna, Havana, Varsóvia, Plymouth, Hong Kong, Buenos Aires, Tallinn, Cluj-Napoca, bem como o "Reconhecimento de Mérite scientifique", da Universidade de Montreal, o Prêmio Sonning da Universidade de Copenhague e o Thalia Prize, da Associação Internacional de Crítica Teatral (IATC). Disponível em <http://www.odinteatret.dk/about-us/eugenio-barba/doctor-honoris-causa-speeches.aspx.> Consulta em 26/04/2014. Em 2014, os atores do grupo receberam também, junto ao diretor, o título de doutores pela Unearte Sede Bellas Artes de Caracas, Venezuela.
}

${ }^{45}$ E aqui incluo a Prof. ${ }^{\text {a }}$ Dr. ${ }^{\text {a }}$ Sayonara Pereira, por sua trajetória totalmente dedicada à dança, contando com dezenove anos de prática artística/docente na Alemanha, posterior Doutoramento direto pela UNICAMP e atual dedicação à docência plena na USP. Cf. capítulo final de seu livro (2010, p. 171-191) no qual seu trajeto é relatado.

\footnotetext{
46 “A imagem barbiana das ilhas flutuantes, nas quais se formam "raízes desenraizadas”, onde o que vigora não são laços espaciais, mas o vínculo a um ethos transcultural que permitiria a mudança de lugares, sem a perda referencial das origens (1991:195), têm pontos em comum com o conceito de rizoma (Deleuze e Guattari: 1995), tão caro aos pesquisadores das artes na contemporaneidade. Tipo de raiz não pivotante, e metáfora para os processos de desterritorialização, heterogeneidade, multiplicidade, micropolíticas, etc, o conceito de rizoma legitima e autoriza aspectos como a diversidade, o hibridismo, a inter, a trans e até a indisciplinaridade. Buscar apoio em outras culturas e linguagens, mestiçar, trocar, desenraizar segundo um ethos, operar na fronteira, são princípios que regem grande parte das abordagens cênicas contemporâneas, dentre as quais o chamado Teatro Físico.” (STEFÂNIA, Alice. 2009, p. 45). Disponível em: 〈http://www.mimus.com.br/4barba2010.pdf〉. Acesso em: 31/05/2014.

47 Talvez isso ainda tenha que ser reconhecido em um país jovem como o Brasil. Em nossa área, como em outras, muitos mestres nacionais também existem (e estão surgindo) a partir da prática exaustiva de um modo de vida que é a tradução de seus conceitos éticos e estéticos de ser-no-mundo. Mas estamos permeados de modelos que, de forma alguma, é denegrir as capacidades locais, sendo antes, aproveitar as facilidades de um mundo sem fronteiras no qual nos reconhecemos e identificamos, segundo parâmetros de condução de um ideal de certa forma testados por alguém, seja aqui ou na Dinamarca.
} 
nominação ao que julgamos, pela experiência, que possa servir em teorias na prática e viceversa.

\subsection{Fundamentos da antropologia teatral}

Para falar sobre os fundamentos da Antropologia Teatral, estabelecida por Eugenio Barba como campo de estudo, apresentamos brevemente a história deste diretor que buscava uma solução para justificar sua diversidade (BARBA, 2010b, p.163). Ele se coloca como italiano de nascimento e formação cultural, norueguês em educação política e polonês no que diz respeito à sua profissão. ${ }^{48}$ Após anos em uma escola militar em Nápoles, Itália, emigrou para a Noruega, Oslo, e trabalhou como soldador e marinheiro, ao mesmo tempo em que cursava Literatura Francesa, Norueguesa e História das Religiões ${ }^{49}$, formando-se, posteriormente, em ambas. Em 1961, deslocou-se até a Polônia para cursar Direção Teatral em Varsóvia, mas conheceu e se juntou a Jerzi Grotowski, diretor polonês obscuro na época, que iria revolucionar o fazer teatral. Barba, então, abandonou o curso formal de direção para tornar-se seu assistente no Teatro das 13 Fileiras (Teatr 13 Rzędów), em Opole. ${ }^{50}$

A partir daí, o jovem Eugenio tornou-se o maior divulgador de Grotowski no cenário mundial da época, escrevendo sobre ele e disseminando os feitos do diretor polonês. Diz Barba que começou a escrever por amor. Tomou uma caneta para defender Grotowski, a quem amava profundamente, ${ }^{51}$ em tempos de censura e ameaça ao Teatr 13 Rzȩdów na

\footnotetext{
${ }^{48}$ Discurso de titulação Doutor Honoris causa na Polônia. Disponível em: <http://www.odinteatret.dk/media/41023/2003,\%20Warsawa\%20Univ\%20-\%20SP\%20Discurso.pdf>. Consulta em 13/08/2012. Cf. também BARBA, 2006, p. 189. Esta informação encontra-se ainda, de forma um pouco diferente, ao considerar sua identificação com grupos latino-americanos, em Teatro, ofício, solidão e revolta (2010a, p. 231), a ver: "Cresci no sul da Itália. Virei adulto na Noruega, como emigrante. Já como homem de teatro, me formei na Polônia. O teatro que fundei é dinamarquês. Mas é no meio dos grupos da América Latina que me sinto em casa.”.

49 Tradução nossa. Informação disponível em: <http://www.odinteatret.dk/about-us/eugenio-barba.aspx>. Consulta em: 12/08/2012. Original: "At the same time he took a degree in French, Norwegian Literature and History of Religions at Oslo University."

${ }^{50}$ Informações disponíveis no endereço eletrônico acima.

${ }^{51}$ Anotação pessoal. A arte secreta do Ator-Brasil, 2010. Nessa confissão de Barba, durante o encerramento do evento, ele mostrava-se particularmente bem-humorado. Falou sobre Eros, no sentido de um amor que não envolve somente o erotismo, mas esse sentimento em todas as suas nuances e nos provocou com alegorias ao nome Eugenio, dizendo que, na verdade, havia assumido a identidade de um irmão morto, que era genial (Eugênio), o qual era quem realmente havia vivido e formulado tudo o que ele narrava. Ele, que se chamava José, era simplesmente um transmissor daquelas experiências e que não entendia nada do que estava falando.
} 
Polônia socialista, ${ }^{52}$ e escreveu diversos artigos pela Europa a fim de difundir a obra do mestre. Segundo ele, um dos maiores ensinamentos que teve junto a Grotowski foi aprender a resistir ao espírito do tempo (BARBA, 2006, p. 63).

Barba também se remete ao mestre, em conversa na Odin Week, ao falar que durante muitos anos enxergava Grotowski - e pedia telepaticamente seus conselhos - no canto da sala, e que ficou surpreso quando ele desapareceu e seu lugar foi ocupado por seus atores. ${ }^{53}$ Porém, nas diferenças também se forjou a personalidade artística de Barba. Como "refugiado", um estrangeiro que não foi aceito, ${ }^{54}$ agregou-se a outros recusados para compor sua própria história. Segundo ele, o Odin Teatret foi criado sobre uma mesma experiência: a exclusão. Como não eram necessários para a sociedade, se quisessem fazer teatro teriam que investir eles mesmos e as soluções tinham que ser inventadas. ${ }^{55}$ A partir daí, com seu próprio grupo fundado, sentiu que devia escrever somente a respeito do que era essencial em teoria e técnica sobre o fazer teatral, e tendo isso em vista, o "essencial" a dizer sobre o teatro, publicou artigos por nove anos, ${ }^{56}$ chegando então ao seu livro: A canoa de papel: tratado de antropologia teatral.

É importante salientar a vivência de Barba na cultura espetacular do Kathakali, durante viagem à Índia, ${ }^{57}$ que o marcará pela observação de espetáculos incompreensíveis, a não ser pela apreciação instintiva daquilo que irá chamar de extracotidiano em suas formulações posteriores, no caso, o que prendia sua atenção como espectador ao ator em cena.

52 Anotação pessoal, oficina A Arte Secreta do Ator-Brasil, 10 de dezembro de 2010. Podemos achar em Ser Pomba e Cobra, capítulo de Terra de Cinzas e Diamantes (2006, p.57-63) o relato de Barba sobre esse momento em que se preocupava com a difusão do que se estava realizando no pequeno teatro de Opole.

53 Anotação pessoal, Odin Week, Holtebro, 25/08/2013. No capítulo O Mestre Invisível (2006, p. 107), narra: "Éramos seis quando o Odin Teatret começou: quatro atores, eu e Grotóvski, que invisível num canto da sala, observava cada detalhe do meu trabalho. Com ele eu não podia trapacear. Quando estava na dúvida, começava a andar pra frente e para trás; na verdade eu me aproximava do canto onde ele estava para pedir um conselho."

${ }^{54}$ E esta é uma questão fundante para o diretor/escritor/teórico/artista. Conta Barba, na Odin Week (Anotação pessoal, 23/08/2013), que procurou no teatro a condição para camuflar-se, pois, se apresentando como artista, as pessoas iriam julgá-lo não pelo que era - imigrante, operário, italiano de pele escura - mas pelo resultado estético de seus trabalhos. Completa: "O teatro, esta anacrônica arte, pode ser um refúgio feito de pessoas que estão fugindo da própria peste."

\footnotetext{
55 Anotação pessoal. Odin Week, Meeting with Eugenio, Dinamarca. 19/08/2014.

${ }^{56}$ Anotação pessoal. A Arte Secreta do Ator - Brasil, 10/12/2010.

${ }^{57}$ Barba conta detalhadamente sua viagem em Teatro, solidão, ofício, revolta (2010a, p. 290-298). E também dedica um pequeno capítulo a essa passagem em Terra de cinzas e Diamantes (2006, p. 73-74). Ver ainda, no mesmo livro, p. 81-85.
} 
As perguntas que lhe foram despertadas sobre o que o fascinava nas encenações assistidas serviram de base para a conformação da Antropologia Teatral (2006, p. 74). Ao pesquisar as bases materiais e os conhecimentos úteis ao ator (BARBA, 2012, p. 14), tal campo agrega "maneiras de pensar a história da técnica pelos princípios que estão na base de diferentes formas expressivas em diferentes tradições" $"$.

Diante dos princípios que foi observando, repetidos no trabalho com seus atores, principalmente depois que voltaram de incursões por locais diferentes do mundo e em diferentes formas de expressão (como uma dança balinesa ou passos do candomblé), Barba (2009, p. 21-22) chegou aos "princípios-que-retornam", ou seja, recorrências que estão presentes em diversas tradições espetaculares e que conferem uma presença extracotidiana $^{59}$ ao ator (2010a, p. 412). Dos fundamentos organizados por Barba, os princípios-que-retornam serviram à utilização prática na obtenção da presença cênica aspirada. Eles são a base da decodificação dos "segredos da técnica" e só podem ser entendidos pelo ator no seu domínio prático. Diz Barba (2012, p. 13, grifos do autor): “O conhecimento dos princípios que governam o bios cênico pode tornar isso possível para quem deseja aprender a aprender, e não apenas aprender uma técnica.”, ou seja, a absorção dos princípios só é possível a quem se disponibilizar a testá-los e, mais do que isso, personalizá-los em um aprendizado contínuo na conquista de recursos como intérprete. São os chamados "bons conselhos", que segundo Barba (2012, p. 14) podem ser acatados ou ignorados, infringidos e superados, mas que podem ser tomados como indicações úteis para ajudar o ator nas tarefas de seu ofício.

O Odin Teatret, celeiro das formulações desse diretor, é um grupo teatral fundado em Oslo em 1964, na Noruega e depois, desde 1966, sediado na Dinamarca, em uma pequena cidade, Holstebro ${ }^{60}$. Denominado como "Teatro Laboratório Escandinavo" (Nordisk

\footnotetext{
${ }^{58}$ Anotação pessoal. A Arte Secreta do Ator - Brasil, 09 de dezembro de 2009.

${ }^{59}$ A característica extracotidiana refere-se a uma construção da presença do ator/bailarino. Ver n.r. 103.

${ }^{60}$ Apesar de pequena (por volta de 30 mil habitantes), a pacata Holstebro tem variada vida cultural. Possui um Ballet e todos os anos abriga o Festuge, festa criada pelo Odin Teatret com diversas encenações e atividades promovidas pelo grupo com a participação dos habitantes da cidade. O ano de 2014 em especial, trouxe como tema da festa "Fantasmas e ficções" e a encenação de uma montagem única, ou seja, realizada apenas uma vez em comemoração aos cinquenta anos do grupo, chamada Claro Enigma (esta encenação pode ser vista em: <http://new.livestream.com/OdinTeatretLiveStreaming/50years> Acesso em 28/08/2014). Na Odin Week de 2013, Roberta Carreri nos recebeu na sede do grupo com a seguinte fala: "Bem vindos ao jardim do cemitério." A esse respeito, durante minha estadia na limpa e linda cidade de Holstebro, entre os participantes era comentário recorrente: “Onde estão as pessoas desta cidade?" tamanho o estranhamento em não ver ninguém na rua. Curiosamente, durante um jantar, que acontecia fora da sede, vi um movimento de pessoas no prédio da frente. Fui conferir, achando que era uma festa, mas se tratava de um encontro na igreja local. Porém, durante o Festuge pude ter outra impressão. As atividades eram todas cheias de moradores de Holstebro e, como tínhamos
} 
Teaterlaboratorium), concentrou-se no treinamento de atores, através do autodidatismo, desenvolvendo, a partir da prática, o conceito de treinamento individual para o ator, derivado de pesquisas herdadas de Grotowski e pedagogos/encenadores/diretores do século XX. O grupo dedica-se, além disso, à transmissão dos conhecimentos técnicos adquiridos nas suas investigações, que contemplam, também, as dramaturgias diversificadas na composição de um espetáculo e as relações com os espectadores. Sobre essa última, podemos citar os chamados Barter, dinâmicas de trocas que nasceram de experiências do grupo em pequenos vilarejos da Itália, nos anos 1970 e perduram até hoje em diversos locais do mundo. Nessas situações, os atores do Odin Teatret "trocavam" com moradores locais danças e cantos, e isso se tornou um pretexto para reunir as pessoas em torno da cultura popular de cada lugar. Barba (2010a, p. 122-123) sublinha que a troca promove-se justamente pela diferença: "Não renunciamos ao que era nosso e eles não renunciaram ao que era deles. Nós reciprocamente nos definimos por meio do nosso patrimônio cultural." O Barter é "uma troca de manifestações culturais e oferece não só um insight entre formas de expressão do outro, mas é igualmente uma interação social que desafia preconceitos, dificuldades linguísticas e as diferenças na maneira de pensar, julgar e agir." ${ }^{\text {"61 }}$ Como repertório, até agora, criaram 76 espetáculos apresentados em 63 países. $^{62}$

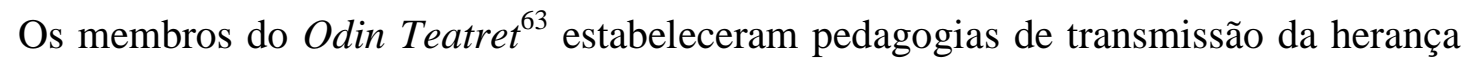
que eles mesmos criaram baseados, por sua vez, no conhecimento herdado por Barba através de Grotowski e outros. Sendo que, pedagogia para o ator, deve ser tomada como um "estudo consciente do próprio corpo, dos mecanismos musculares, das leis psicofísicas que determinam esses mecanismos, das diferentes formas de controlá-los e transformá-los em meios de expressão artística." (BARBA, 2010a, 34). Esse é um aspecto muito importante ao falarmos da trajetória e herança que o grupo vem construindo. Roberta Carreri conta que, nos

que nos deslocar por vários pontos para acompanhar a programação, pude ver a vida normal da cidade, que é basicamente diurna.

61 "The barter is an exchange of cultural manifestations and offers not only an insight into the other's forms of expresssion, but is equally a social interaction which defies prejudices, linguistic difficulties and differences in thinking, judging and behaving." STUDIA UBB DRAMATICA, LIX, 1, 2014, p.12.

${ }^{62}$ Ibidem.

${ }^{63}$ Os quatro primeiros que acordaram em se aventurar com o jovem Eugênio Barba no grupo foram Else Marie Laukvik, Torgeir Wethal, Tor Sannum, Anne-Trine Grimnes, aspirantes a atores refutados pela academia local. (BARBA, 2006, p. 92). Desses, continuaram Wethal (até seu falecimento em 2010) e Laukvik. Além dela, o grupo atualmente é composto por Iben Nagel Rasmussen, Roberta Carreri, Julia Varley, Tage Larsen, Jan Ferslev, Kai Bredholt, Frans Winther, Sofia Monsalve, Donald Kitt e Elena Floris. Disponível em: <http://www.odinteatret.dk/about-us/actors.aspx>. Acesso em 27/04/2014.. 
idos de 1970, quando ingressou no Odin Teatret, teve que organizar rapidamente os ensinamentos que recebeu de Torgeir Wethal e Iben Nagel Rasmussen para ministrar cursos sobre treinamento para o ator. ${ }^{64} \mathrm{Em}$ um tempo em que tudo era descoberta, a necessidade se torna um fundamento para a ação. Essa necessidade está conectada à crença no que se está fazendo e na capacidade de realizar o que se diz. Então, o treinamento de cada ator tornou-se uma "tradição", com várias estratégias e procedimentos organizados em uma lógica pessoal, mas passíveis de serem transmitidos, ${ }^{65}$ a fim de conquistar o corpo extracotidiano e chegar à "presença cênica", um estar diferenciado que o ator domina em suas apresentações. Cabe apontar que, contemporaneamente, esta é uma abordagem muitas vezes vista como "ultrapassada", principalmente pela incidência da performance ${ }^{66}$ art, na qual as dissociações entre cotidiano e extracotidiano caem por terra, ${ }^{67}$ e muitas vezes o próprio "preparar-se" já é cena. Mas, uma vez que o recorte privilegia os procedimentos adotados e transmitidos pela tradição do Odin Teatret, especificamente o confronto com o corpo performático é uma discussão que não cabe neste estudo,

Em 1979, Eugenio Barba fundou a ISTA (International School of Theater Antropology) ${ }^{68}$ e, em 1980, realizou o primeiro encontro em Bonn (Alemanha), a fim de investigar o que havia observado. Em um campo ampliado de pesquisa, ele reuniu diversos

\footnotetext{
${ }^{64}$ Anotação pessoal. Odin Week, Holstebro, 2013. Cf. também: CARRERI, 2011, p. 41.

${ }^{65}$ Entre os atores do Odin Teatret há diferentes graus de organização das técnicas pessoais na transmissão pedagógica. Iben Nagel Rasmussen, Roberta Carreri e Julia Varley destacam-se na sistematização de seus procedimentos e aplicação ao ensino, bem como no registro sobre seus trabalhos. Neste último quesito, Julia Varley é quem tem mais textos publicados, fazendo parte de sua tradição também a preocupação com a documentação pela ótica do ator/atriz.
}

${ }^{66}$ Segundo Pavis (2010, p.43-46), o termo performance, no campo artístico, abarca a circunscrição de um gênero mas tem diferentes sentidos para a escola inglesa e francesa, sendo, respectivamente, que o termo "[...] aplicado ao teatro, designa aquilo que é desempenhado pelos atores e realizado por todos os colaboradores da 'representação, ou seja, daquilo que é apresentado a um público após um trabalho de ensaios." e "[...] em francês ela manteve apenas o sentido de façanha [...]". Ressalta que nos dois sentidos, “[...] indica que uma ação é executada pelos artistas e que também é o resultado dessa execução.” Apontada a distinção, esclarecemos que a partir daqui, o termo performance será usado no texto conforme sua acepção inglesa, que pode se equivaler à encenação ou ao desempenho do ator na mesma.

${ }^{67}$ Cf. BONFITTO, 2013, p.157.

${ }^{68}$ Em um artigo intitulado How Ista came into being, Barba (apud HASTRUP, 1996, p. 24) conta: "Meu desejo de escrutinar simultaneamente diferentes técnicas de atuação foi fruto de meu frequente contato com os performers clássicos asiáticos." Tradução nossa. Original: "My desire to scrutinize simultaneously different acting techniques stemmed from my frequent contacts with classical Asian performers." 
estudiosos, atuadores e demais categorias das artes cênicas ${ }^{69}$ para discutir e sistematizar um saber prático, "saber tácito" que está presente desde as mais antigas formas de preparação para a cena. $\mathrm{O}$ “ 'território empírico’ visando superar as especializações disciplinares, técnicas e estéticas" (BARBA \& SAVARESE, 2012, p. 13). A famosa e replicada premissa é formulada: "Antropologia Teatral é o estudo do comportamento cênico pré-expressivo que se encontra na base dos diferentes gêneros, estilos e papéis das tradições pessoais e coletivas." (BARBA, 2009, p.25). Ainda, “[...] a antropologia teatral é o estudo do comportamento do ser humano que utiliza sua presença física e mental em uma situação de representação organizada segundo os princípios que são diferentes daqueles da vida cotidiana." (BARBA \& SAVARESE, 2012, p.13).

A noção que Barba instaura, ao propor o exame do fazer teatral na aproximação com território empírico em que se desenvolve, é de que a situação de representação pode ser estudada em seu nível pré-expressivo $(2009$, p. 26) inerente a qualquer cultura ou tradição. A pré-expressividade é tomada como um “[...] nível operativo; [...] uma práxis que, durante o processo, tem como objetivo desenvolver e organizar o bios cênico do ator [...]" (2009, p. 172, grifos do autor). Toma o treinamento na acepção inglesa da palavra "training ${ }^{70 \text { " que }}$ também quer dizer aprendizado, para desenvolver a plataforma da pré-expressividade (BARBA \& SAVARESE, 2012, p. 228): “O nível que se ocupa de como tornar cenicamente viva a energia do ator, ou seja, de fazer com que ele se torne uma presença que atrai imediatamente a atenção do espectador, é o nível pré-expressivo. Esse é o campo de estudo da antropologia teatral.” Franco Ruffini (apud BARBA \& SAVARESE, 2012, p. 62) definirá o nível pré-expressivo como "aquele em que o ator constrói e dirige sua presença em cena, antes mesmo dos seus objetivos finais e dos seus resultados expressivos, e independentemente deles."

Pavis (2008, p. 19) aponta algumas incongruências da Antropologia Teatral ao ressaltar que Barba, estabelecendo a diferença entre corpo cotidiano e corpo em situação de representação, como se se pudesse separar o cultural da natureza, cria uma fissura inconciliável entre vida e representação. Pensando na tal "segunda natureza", entendemos que há muitas mais, que não se sobrepõem em camadas, mas coexistem no corpo-mente do ator.

\footnotetext{
${ }^{69}$ Os parceiros, de diversas partes do mundo, Toni Cots, Sanjukta Panigrahi, Katsuko Azuma, I Made Pasek Tempo, Tsao Chun Lin, Fabrizio Cruciani, Franco Ruffini, Nicola Savarese, Ferdinando Taviani e Ugo Volli, Jean-Marie Pradier são considerados por Barba como cofundadores da tradição da ISTA. Ibidem, p. 25.

${ }^{70}$ Tomado por uma de suas acepções em inglês, por isso o termo não traduzido, como nos explicou. Anotação pessoal, A Arte Secreta do Ator-Brasil, Brasília, 2009.
} 
Existem ainda outras problematizações sobre as noções que Barba elabora em suas publicações sobre o trabalho do ator. Pavis atribui às formulações um saber majoritariamente pragmático e indica questionamentos, notados por Bonfitto (2013, p. 157):

[...] a falta de articulação entre os aspectos considerados por Barba como préexpressivos; a ausência de um exame mais detalhado e aprofundado das culturas teatrais das quais ele se vale, assim como a vulnerabilidade de suas formulações quando vistas de um ponto de vista teórico.

Ginbusburg et al (2009, p.34) salientam a crítica de De Marinis ao apontar o perigo de que, ao não levar em conta as diferenças entre as manifestações teatrais estudadas, corre-se o risco de anular as especificidades de identidade expressiva de cada uma delas . É notório que Barba se utiliza de cruzamentos interculturais ${ }^{71}$ e aspira à transculturalidade como uma síntese possível das suas formulações. Nesse aspecto, Pavis também salienta a apropriação e uma certa pasteurização em favor de uma estética desconectada das fontes. Ponderamos que Barba, ao realizar tais reduções, alcança um patamar em que tem sempre razão, pois aponta claramente os princípios visíveis em culturas diferentes, mas no qual nem sempre está certo, por, de certa forma, homogeneizá-los. ${ }^{72}$

Mas encontramos em Barba,

\begin{abstract}
Algumas pessoas estão perplexas e dizem: "Como é possível estudar os processos criativos dos artistas sem examinar seu contexto histórico e social? Como é possível comparar diversas formas de comportamento cênico, e isolar princípios transculturais, sem levar em consideração o fato de que cada um dos exemplos pertence a circunstâncias culturalmente diversas e épocas não comparáveis?" E concluem: "Antropologia Teatral ignora a história; ignora o fato de que determinados procedimentos técnicos têm um significado simbólico ou ideal específico na cultura a que pertencem; reduz tudo à materialidade do bios cênico, à presença do performer". Não, Antropologia Teatral não reduz a... mas se concentra em. $^{73}$
\end{abstract}

\footnotetext{
${ }^{71}$ Pavis $(2008$, p. 210) fala de um "teatro intercultural [... como um estilo ou uma prática de jogo teatral aberta a diversas fontes culturais."

${ }^{72}$ Reflexão desenvolvida a partir de uma conversa com a Prof. ${ }^{a}$ Claudia Jenchke, por ocasião de seu curso Lecture Performance, promovido pela Prof. ${ }^{a}$ Dr. ${ }^{a}$ Sayonara Pereira, na ECA-USP (19/08 a 23/08).

73 "Identidade cultural e identidade profissional". Tradução nossa. Original: "Some people are perplexed and say: 'How is possible to study the performers'creative processes without examining their historical and social context? How is it possible to compare various forms of scenic behavior, and isolate transcultural principles, without taking into consideration the fact that each of examples belongs to culturally diverse and times incomparable circumstances?' And they conclude: 'Theatre Antropology ignores history; it ignores the fact that particular technical procedures have a specific symbolic or ideal meaning in the culture to which they belong; it reduces everything to the materiality of scenic bios, the performer's presence'. No, Theatre Antropology does not reduce to... but concentrates on." Cultural identity and professional identity. In The Performer's Village . 1996, p. 29.
} 
Entendemos que as críticas do semiólogo francês Pavis têm sua base ao tomar as teorias de construção de conhecimento debruçadas sobre a articulação entre conceitos. No entanto, pensamos que uma das críticas, do conhecimento ser basicamente formulado a partir da prática, não deixa de apontar o que realmente funda o conhecimento do campo teatral, principalmente a partir de Stanislavski, que sistematizou os saberes, formulando-os e apontando ainda outros. Mas podemos retomar ainda os procedimentos da Commedia dell'arte, como imitação, oralidade e codificações na transmissão do conhecimento do fazer teatral, que se dava de ator para ator.

Também pela vivência nos cursos, não distinguimos a falta de articulação de que Pavis fala entre os aspectos pré-expressivos. Ao contrário, em cada exercício ou direção aplicado por Barba (e seus atores), os princípios são claros e interligados ${ }^{74}$ e muitas vezes referenciados de suas fontes, como é o caso na tradição de Carreri (2011, p.141-144) que personalizou influências de fontes orientais. Em 2012, durante o curso A Arte Secreta do ator - Brasil, Barba utilizou-se de algumas especialidades dos participantes para expor à turma os aspectos pré-expressivos reconhecíveis em diversos treinamentos ou linguagens cênicas e suas aplicações em cena. A atriz argentina e colaboradora do Odin Teatret Ana Woolf fez uma demonstração do treinamento da técnica $S_{u z u k i}{ }^{75}$; a atriz e diretora Luciana Martuchelli demonstrou o treinamento de Tai Chi Chuan baseado na técnica Pai Lin e alguns exercícios vivenciados por ela durante sua estadia no Núcleo CPT, dirigido por Antunes Filho ${ }^{76}$, em São

\footnotetext{
${ }^{74}$ No Dicionário de Antropologia Teatral (BARBA \& SAVARESE, 2012) há também várias ilustrações entre técnicas e culturas diferentes que evidenciam esses princípios pré-expressivos mapeados pelo diretor, como $\mathrm{p}$. ex. nas páginas 94 e 95 evidenciando o equilíbrio precário na dança, pintura, ballet e entre atores ocidentais e orientais.

75 Técnica fundada por Tadashi Suzuki (1939), diretor japonês, com grande reconhecimento e mobilidade internacional. Seu método ganhou particular amplitude ao ser adotado como preparação para o Viewpoints, outra técnica de treinamento fundada e difundida por Anne Bogart (1951). Particularmente, tive acesso ao método Suzuki com a atriz e diretora Cristiane Zuan Esteves, durante um curso de Viewpoints, durante dois anos no extinto Estúdio Move, em São Paulo, 2005/2006. É um trabalho corporal exigente, com muito treino do Koshi (v. p. 142 deste trabalho), atenção aos pés e grande esforço para os joelhos. Um dos exercícios mais difíceis que fiz em minha vida foi durante esse treinamento, que consistia em ir ao chão, mantendo o "centro", ou seja, um ponto referenciado abaixo do umbigo, que contém a "energia vital" e, uma vez no chão, abandonando esse referencial, retomá-lo para levantar a partir dele, estruturando todo o corpo na posição em pé.

${ }^{76}$ Em A ostra e a pérola, Mariz (2008, p. 132-154) dedica um capítulo à análise da pesquisa desse diretor, ressaltando, entre as diferentes abordagens em relação a Grotowski e Barba, a mesma vontade ética de que o teatro proporcione outros paradigmas de valores possíveis ao mundo.
} 
Paulo. O ator e Prof. Dr. Ricardo Gomes ${ }^{77}$ demonstrou partes do treinamento e posturas do Katakhali. Alguns demonstraram também composições com os elementos dos treinamentos, trazendo, em pequenas partituras, as conexões entre a preparação e a cena. Durante as demonstrações, as confluências dos princípios eram apontadas e comentadas, como as incoerências coerentes, oposições e omissões, os equilíbrios de luxo e as equivalências. ${ }^{78}$ Apesar de aspectos totalizantes, que podem colocar tudo no mesmo "balaio", compreendemos, principalmente, nas sutilezas de cada técnica e suas realizações, aquilo que pode estabelecer o interesse no espectador; a característica de despertar o olhar e promover identificação, independentemente da compreensão de signos ou do que "se quer dizer". Claramente o domínio da técnica é um fator que aviva a presença do ator, pois, na cena, a movimentação precisa permite que a "alma" do executante se reflita desde que também se façam as conexões com os materiais interiores e, apesar da frieza da execução técnica, vêm à tona as motivações internas que permeiam o desempenho. A execução da técnica passa pela personalização, ou seja, pelo trabalho sobre si mesmo, na perscrutação sobre o que estamos expondo: o virtuosismo ou nossa humanidade? Encontrar o conforto da execução técnica precisa esconde as horas dedicadas ao fazer e abriga o diálogo entre a forma e conteúdo do ator.

Pensamos, ainda, que as noções detalhadas como princípios pré-expressivos, não são "coisa dada" ao ator, inertes e estáticas. Ao contrário, dependem da experiência real, colocarse a disposição com o corpo, para reconhecê-los e os comprovar ou refutar. O treinamento serve a isso. E mesmo sem conhecê-los teoricamente, ou seja, pela sua conceituação, ao se colocar em situação de achar respostas a partir do corpo, o ator irá experimentá-los. Os atores do Odin Teatret, durante os cursos ou em entrevistas, comentam que muitas das palavras usadas por Barba nunca fizeram parte de seus vocabulários em sala de ensaio. "Extracotidano", por exemplo, como registra Varley na Arte secreta do ator - Brasil, em 2009 e "pré-expressividade", também relatado por ela, desta vez na Odin Week de $2013 .{ }^{79}$ Mas todos reconhecem nos conceitos desenvolvidos pelo diretor o que viviam nos treinamentos e os resultados alcançados em cena.

\footnotetext{
${ }^{77}$ Sua tese de doutorado Kathakali vesham: l'apprendistato dell'attore Kathakali concentrou-se nessa tradição indiana e o treinamento de seus atores. Cf. texto Kathakali Vesham, disponível em: <http://portalabrace.org/memoria/vcongressoetnocenologia.htm>. Acesso em 04/06/2014.

${ }^{78}$ Ver Capítulo I, p.66,67 deste trabalho.

${ }^{79}$ Anotações pessoais dos respectivos cursos.
} 
Voltando ao contexto histórico, há que se ressaltar ainda o relacionamento antigo de Barba e o grupo com a América Latina, onde ele diz se sentir em casa. Segundo Lluís Masgrau (1994/95, p. 145), professor, escritor e colaborador do Odin Teatret, a primeira viagem do grupo aconteceu em 1976, para a Venezuela, no Festival de Caracas, entrando em contato e estabelecendo relações de amizade com encenadores e grupos teatrais da América Latina na época (p. 145). Apesar de receberem muitas críticas, principalmente "daqueles que viam no Odin uma nociva influência colonialista que atentava contra as formas e manifestações teatrais autóctones", ${ }^{80}$ Masgrau salienta a face reversa da influência, inspirando Barba à formulação da noção do Terceiro Teatro, lapidada ao longo das relações com o teatro latino-americano e chegando à dimensão que se refere à ética como pilar das práticas teatrais, tanto do passado quanto do presente, sendo que buscam um sentido autônomo e pessoal. $\mathrm{O}$ Odin Teatret influenciou aqueles que reconheciam na proposta da Antropologia Teatral as formulações e técnicas que se concentram nos aspectos artesanais do ofício, de forma prática e eficaz. E, mesmo gerando cópias inicialmente, as propostas adotadas começaram a ser adaptadas em estratégias pessoais de grupos como o Yuyachckani, que segundo Masgrau (1994/95, p.153-154), foi um dos que tirou "bom proveito" das indicações de Barba. O Brasil também faz parte dessa rede de interinfluências, sendo hóspede do grupo a partir de 1978, quando dois atores do Odin Teatret chegaram à Bahia para aprender capoeira; em 1987, com a realização de um encontro em Campinas e São Paulo, organizado por Luiz Otávio Burnier, fundador do grupo Lume; em diversos seminários nos anos 1990, incluindo a realização da $8^{\text {a }}$ sessão da ISTA, em Londrina (1994), e já no século XXI, com inúmeras visitas do grupo para espetáculos e seminários ou de alguns integrantes para palestras e demonstrações de trabalho ${ }^{81}$.

\subsubsection{O ensemble: atrizes e atores do Odin Teatret na atualidade ${ }^{82}$}

\footnotetext{
80 Tradução nossa. Original “[...] de aquellos que veían em el Odin uma nociva influencia colonialista que atentaba contra las formas y manifestaciones teatrales autóctonas.” MASGRAU, 1994/95, p. 147.

${ }^{81}$ A pesquisadora Patrícia Furtado de Mendonça, atriz e docente no Rio de Janeiro, colaboradora e tradutora do Odin Teatret vem mapeando as influências e incursões do grupo no Brasil. Um primeiro levantamento foi publicado especialmente na edição brasileira de Teatro, Solidão, Ofício, Revolta (apud BARBA, 2010a, p. 384409).

${ }^{82}$ A "atualidade" refere-se a 2014, ano de conclusão desta pesquisa. Entre parênteses, após cada nome, estarão ano e local de nascimento. As informações aqui reunidas tomam por fontes principais o site oficial do grupo (disponível em: <http://www.odinteatret.dk/about-us/actors.aspx>) e o artigo Los actores del Odin, da Revista Máscara, edição comemorativa de 30 anos do Odin Teatret (Out-1994/95, RISUM p. 31-59). Outras fontes eventuais serão sinalizadas no texto ou em notas de rodapé.
} 
Protagonistas das tradições documentadas nesta pesquisa faz-se necessária uma breve apresentação dos atores do Odin Teatret. Por ordem de chegada ao grupo, seguem pequenas biografias dos membros ainda ativos. ${ }^{83}$

\subsubsection{Else Marie Laukvik}

(1944 - NOR) Foi uma das primeiras a se juntar ao Odin Teatret, por ocasião de sua fundação em 1964, ainda na Noruega e acompanhou a mudança para a Dinamarca. Não tinha nenhuma preparação como atriz no primeiro treinamento do qual participou com Barba e lhe pareciam difíceis as palavras do diretor sobre Grotowski. Mas conta que achou um sentido de pertencimento dentro do grupo, tornando-se, no início dos anos 1970, a principal transmissora dos exercícios praticados no treinamento para os atores que viriam a seguir. ${ }^{84}$

Como atriz de vários trabalhos no Odin Teatret, de 1965 a 1987, encerrou sua participação nos espetáculos coletivos depois de $O$ evangelho de Oxyrhincus. $^{85}$ Em 1990, criou o espetáculo Memória, ainda parte do repertório atual da companhia, no qual Laukvik apresenta-se junto ao músico Frans Winther, também integrante do grupo, contando-nos histórias sobre o extermínio nazista aos judeus.

Possui uma demonstração de trabalho ativa chamada My Stage Children (Minhas crianças de palco), na qual fala de sua carreira como atriz e apresenta a vida de suas

\footnotetext{
${ }^{83}$ Muitos outros atores passaram pelo grupo e tiveram sua importância na história do Odin Teatret. Destacamos Togeir Wethal (1947-2010), ator da formação original na Noruega, e Augusto Omulú (1962-2013), atorbailarino brasileiro que permaneceu de 2002 a 2013. Mais informações podem ser consultadas no endereço eletrônico do grupo, na aba Actors in the past.

${ }^{84}$ Apesar desse reconhecimento narrado em livros e ressaltado por Varley, por exemplo, durante um workshop com a atriz, (anotação pessoal: "Else Marie contém todos os princípios muito claros em seu corpo." São Paulo, em 2013) disse-me Laukvik, em entrevista, que nunca foi um exemplo no treinamento. Isto me suscita reflexões sobre o quanto de reconhecimento necessitamos como artistas e pedagogos e o quanto podemos dimensionar o alcance sobre o que detemos e fazemos.

${ }^{85}$ Laukvik conta que a personagem Zucha Mal'ak, desse último espetáculo, consumia tanto sua energia que quase a matou, mas também a fez acreditar que é possível superar as dificuldades. Sobre essa personagem, registra: "[...] ele sabia que milagres podem acontecer porque nós todos somos pequenos milagres. Mas para alcançar algo, é preciso dar ou sacrificar alguma coisa." Tradução nossa. Original: "[...] he knew that miracles can happen, because we are all small miracles. But to achieve something, you must give or sacrifice something." Do Miracles Happen? In: The open page. Holstebro: Odin Teatret Forlag,1998. p. 26.
} 
personagens por meio de fragmentos de filmagens feitas ao longo da mesma. Na introdução nos brinda com a seguinte fala: "Estou agora nos meus sessenta anos e sinto que é hora de olhar para trás. Criatividade é como um ato contínuo de dar à luz e todas as figuras a que eu dei à vida no teatro, são meus filhos de palco, que eu gostaria de encontrar e reviver mais uma vez." ${ }^{86}$

Laudvik tem grande experiência na construção de máscaras, adquirida em um estágio no Haiti e são notórias suas habilidades na confecção de figurinos. Uma personagem emblemática criada por ela é a "Andrógina", que, sobre pernas-de-pau, vestida de preto e vermelho com detalhes em branco, de face branca com boca carmim e uma longa peruca de penas negras, é um gigante de longas unhas como as das bruxas balinesas e até hoje se faz presente em várias performances do grupo, vestida por atores mais jovens, como Sofia Monsalve.

Dedica-se ainda à direção de grupos na Dinamarca, em peças, musicais e trabalhos com crianças.

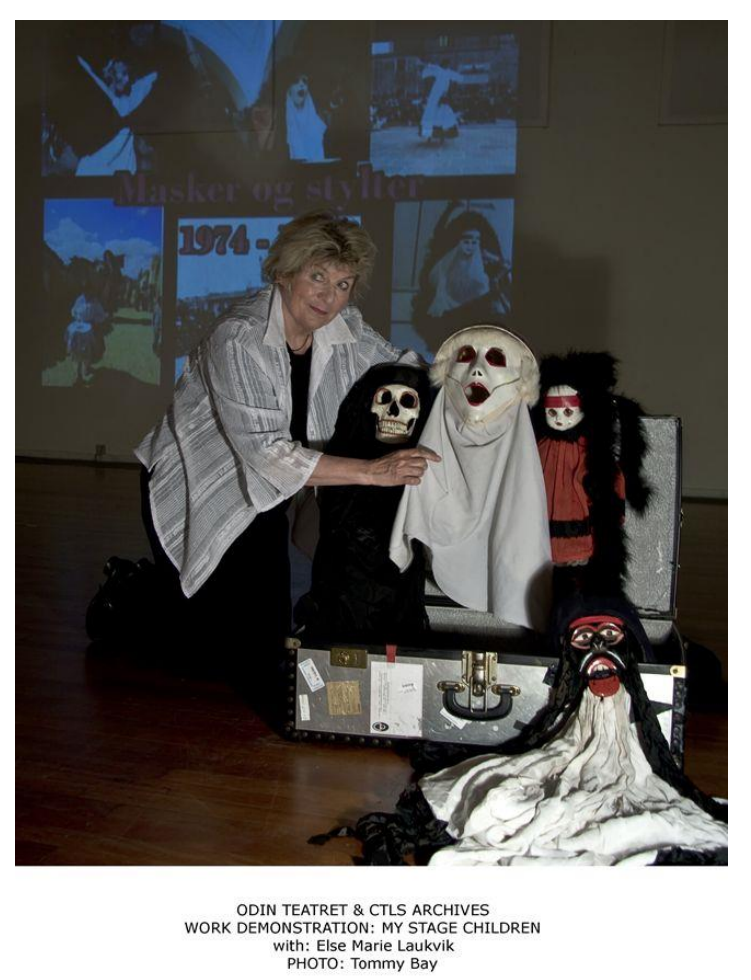

Figura 2. My stage children com Else Marie Laukvik. Foto oficial do Odin Teatret.

${ }^{86}$ Tradução nossa. Original: "I am now in my sixties and I feel it is time for me to look back in time. Creativity is like a continuos act of giving birth and all the figures that I have given life to in the theatre, are my stage children, that I would like to encounter and to revive once more." Disponível em: <http://www.odinteatret.dk/productions/work-demonstrations/my-stage-children.aspx >. $\quad$ Consulta em 17/05/2014. Este ano, a atriz comemorou 70 anos. 


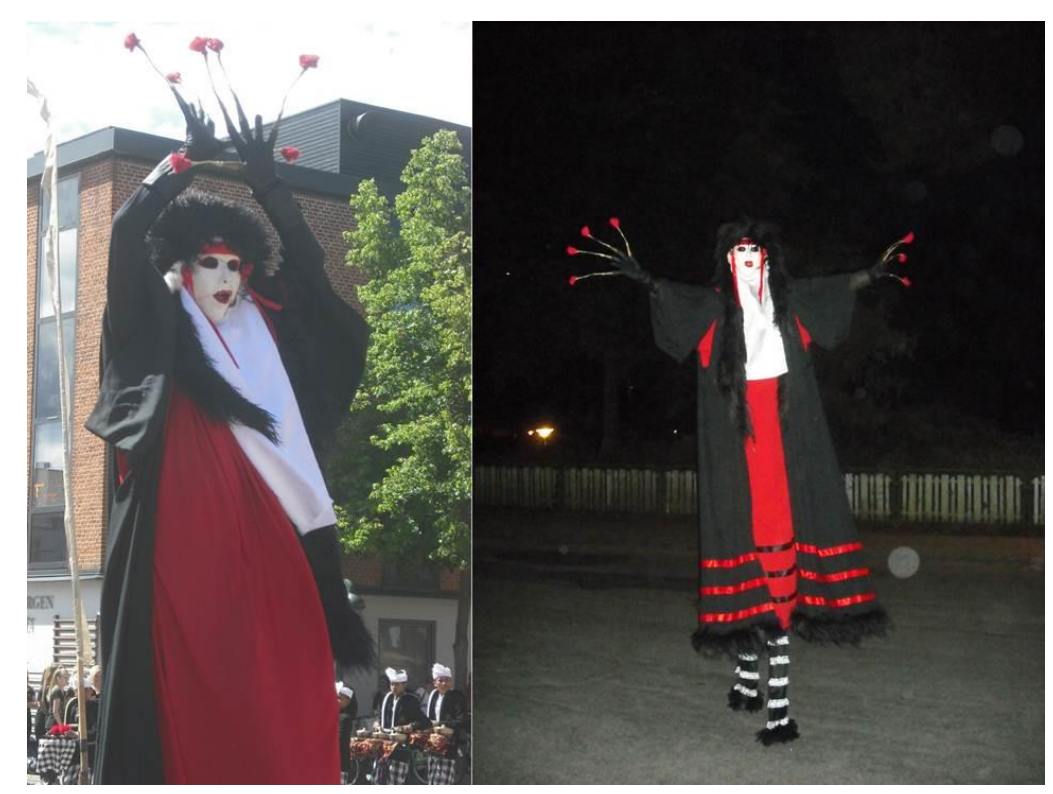

Figura 3. Andrógina. Festuge, Holstebro, 14 e 18/06/2014. Fotos e montagem: Leticia Olivares.

\subsubsection{Iben Nagel Rasmussen}

(1945 - DK) Atriz, diretora, professora e escritora. Rasmussen juntou-se ao grupo na chegada do Odin Teatret à Dinamarca em 1966. Filha de escritores famosos do país, antes de entrar para a companhia passou por uma fase hippie, na qual sobrevivia junto a seu namorado Eik Skaløe, poeta beat danês, em uma vida errante. Juntou-se ao Odin Teatret quando este se mudou para a Dinamarca, em 1966. Ela fala que a entrada na companhia deu-lhe força para superar suas batalhas internas e se livrar da morte, que acabou encontrando Skaløe, em 1968. Essa fase de sua vida encontra-se na potente encenação Itsi-Bitsi, na qual, junto a Kai Brethold e Jan Ferslev, atores e músicos do grupo, apresenta sua autobiografia artística. Conta Rasmussen:

[...] sou filha da cultura dos anos sessenta, da experiência com a liberdade, a rebeldia, as drogas: todas essas experiências que me marcaram profundamente. Profissionalmente, eu sou filha de Eugenio: eu comecei do zero com ele. Talvez, 'profissionalmente' não seja a palavra certa, para mim, Eugenio era como um guru, um professor que me ensinou muito mais do que o trabalho. ${ }^{87}$

${ }^{87}$ Tradução nossa. Original: “[...] sono figla della cultura degli anni Sessanta, dell' esperienza com la libertà, la rivolta, la droga: tutte esperienze che mi hanno profondamente segnato. Professionalmente, sono figlia di Eugenio: com lui ho cominciato da zero. Forse, 'professionalmente' non è la parola giusta, per me Eugenio è stato come um guru, um maestro che mi há insegnato molto più che il mestiere." Il Ponte dei Venti. Un'esperienza di pedagogia teatrale com Iben Nagel Rasmussen. Copenhagen: F. Hendriksens Eftf., 2001, p. 8. 
Após passar pelo período de treinamento com os atores mais antigos, Wethal e Laudvik, com ênfase nos aspectos acrobáticos e exercícios inspirados no trabalho de Grotowski, Rasmussen foi a primeira a "inventar" o próprio treinamento, buscando dentro de si as respostas para formulações como "o que é uma ação dramática? [...] Não em geral, mas para mim." $" 88$ A partir daí, desenvolveu uma gama de exercícios, chamados "exercícios suíços", por estarem nesse país quando os apresentou à Barba, e achou a fluidez e o sentido intrínseco do treinamento para si mesma. Conta que, inicialmente, se inspirou em Isadora Duncan como uma maneira vital de utilizar o espaço, com quedas, saltos e diferentes maneiras de sentar-se.

Quando Barba decidiu que não precisava de mais atores no grupo, Rasmussen rebelouse e, constatando que era importante para ela como atriz transmitir o que sabia, levou Barba a fundar a tradição da "adoção". Nessa tática, qualquer ator novo deveria ficar aos cuidados do seu padrinho, que era responsável pelo seu abrigo, alimentação e ensinamentos. ${ }^{89}$

Incomodou-se em ministrar cursos rápidos, que não tinham continuação, pois para ela o importante é a duração. Este foi um dos impulsos para, após um seminário em 1980 ministrado no monastério de Farfa, Itália (2001, p.11), fundar em 1983 o grupo de mesmo nome com atores de vários países. Lidera também o grupo Ponte dos Ventos (Vindenes Bro), projeto pedagógico que reúne atores da América Latina e Europa desde 1989 e em 1999, do qual participa, entre outros brasileiros, o ator Carlos Simioni (Grupo Lume - Campinas, SP). Criou ainda um novo grupo, no modelo do anterior, chamado Novos Ventos (Nye Vinde) que reúne jovens atores. Mantém encontros regulares com os grupos na pesquisa do ofício.

\footnotetext{
${ }^{88}$ Tradução nossa. Original: “[...] chè cos’èun ‘azione drammatica? [...]Non in generale: per me.” (2006, p. 204).

${ }^{89}$ Pontua Varley (2010 p. 41): “A adoção era uma solução inventada por Eugenio para contentar os veteranos que queriam inserir novas pessoas no grupo. Eugenio não sentia essa necessidade e exigia que quem quisesse assumisse a responsabilidade econômica e pedagógica pelo jovem que havia convidado."
} 


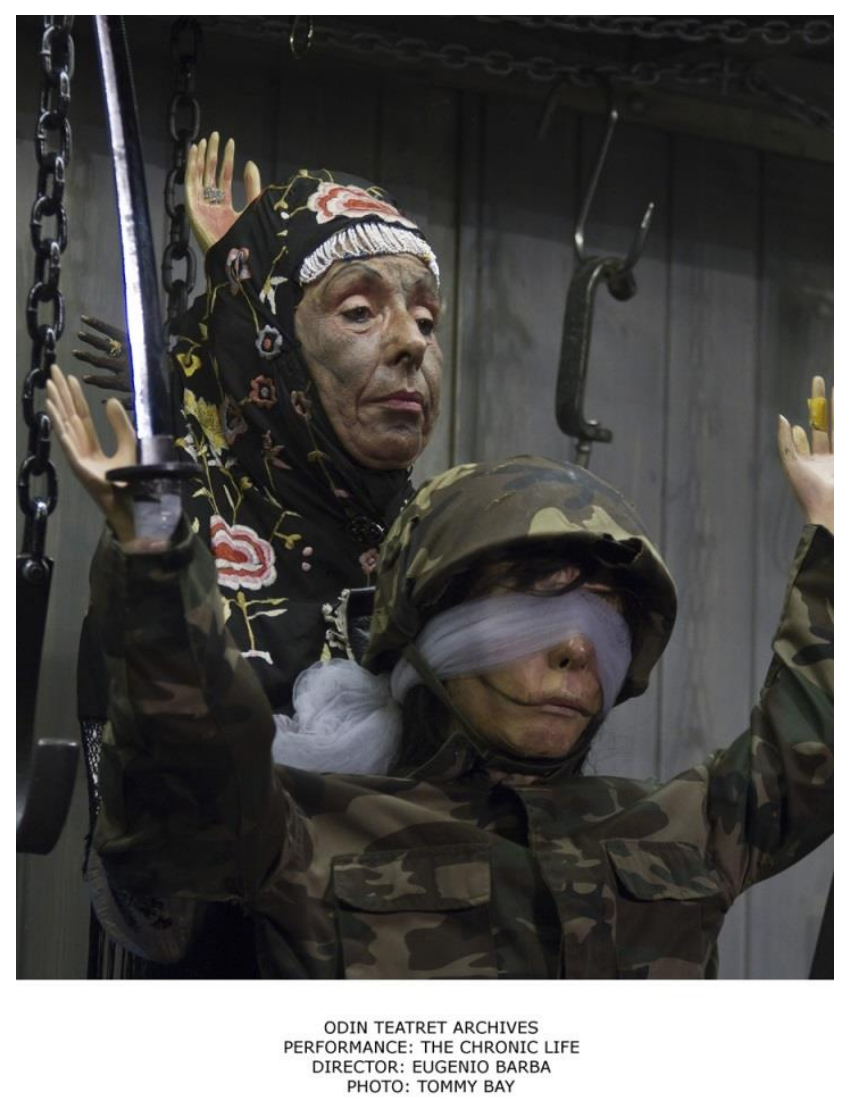

Figura 4. Iben Nagel Hasmussen em A Vida Crônica. Foto oficial do Odin Teatret.

\subsubsection{Tage Larsen}

(1949 - DK) Entrou para o Odin Teatret em 1971 e permaneceu até 1974, retornando no ano seguinte para ficar até 1987, quando se afastou por dez anos. Em 1997, quando voltou ao grupo, tomou parte do espetáculo Mytos, continuando até hoje. No tempo de afastamento criou o grupo Yorick Teatret, foi professor do Nordisk Teater Skole em Århus e trabalhou como ator com o Teater La Balance and Cantabile 2. Também dirigiu peças com elencos de várias partes do mundo como Dinamarca, Canadá, Malásia e Itália. É responsável pela organização e performances do Holstebro Festuge Festive Week, festa anual promovida pelo grupo com participação de toda a comunidade da cidade, grupos locais e internacionais convidados. Ministra oficinas no programa pedagógico do Odin Teatret em turnês e em outros grupos teatrais do mundo. 


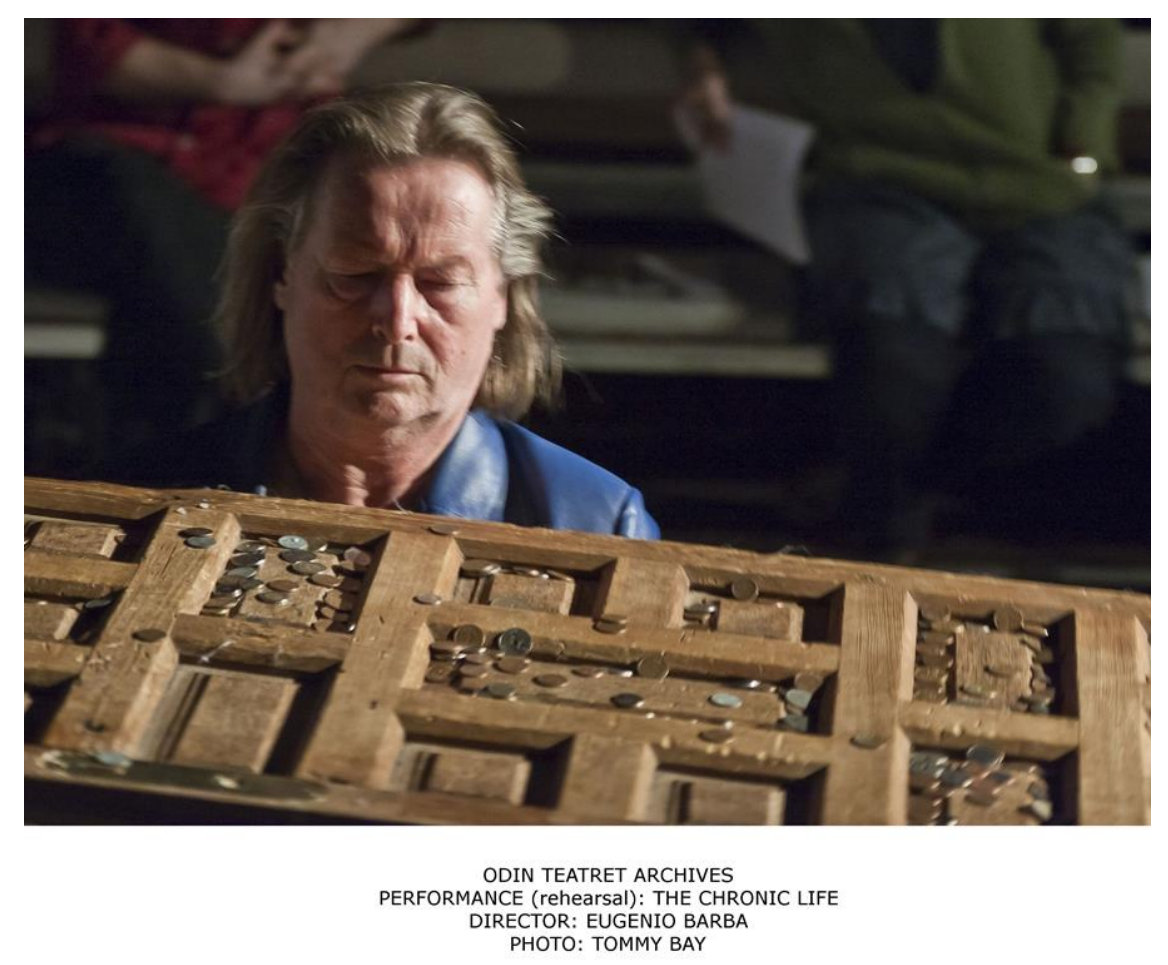

Figura 5. Tage Larsen em A vida Crônica. Foto Oficial do Odin Teatret.

\subsubsection{Roberta Carreri}

(1953 - ITA) É atriz, professora, escritora, diretora e organizadora. Formou-se Publicidade e Design e estudou História da Arte na Universidade Estadual de Milão. Juntouse ao Odin Teatret em 1974, durante a estada do grupo em Carpignano, Itália. Nunca havia feito teatro antes e tomou treinamento com Torgeir Wethal e Iben Nagel Rasmussen. Também foi orientada diretamente por Barba até iniciar seu treinamento pessoal. Roberta Carreri participou da ISTA desde o seu início em 1980, entrando em contato com técnicas do Japão, Índia, Bali e China, que influenciaram seu trabalho como atriz e professora. Entre os anos de 1980 e 1986, estudou com mestres japoneses como Katsuko Azuma (dançarina de Nihon Buyo - dança tradicional japonesa), Natsu Nakajima e Kazuo Ohno (dançarinos de Butoh). Ministra oficinas para atores de todo o mundo e sua demonstração de trabalho, Traces in the Snow, é sua autobiografia profissional. É organizadora do Odin Week Festival, evento anual que reúne artistas e pesquisadores interessados no trabalho do grupo anualmente em Holstebro. 


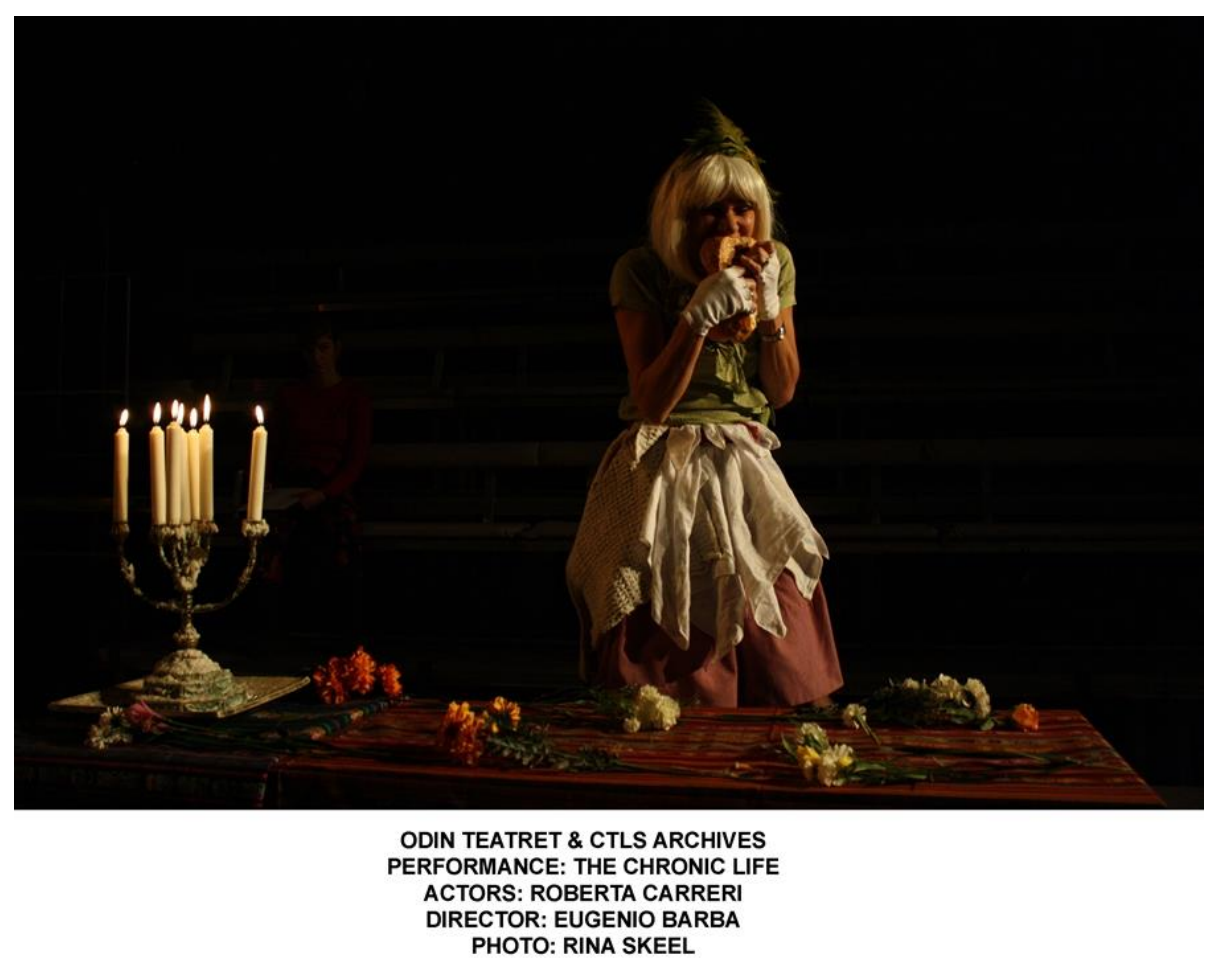

Figura 6. Roberta Carreri em A Vida Crônica. Foto oficial do Odin Teatret.

\subsubsection{Julia Varley}

(1954 - ING) Mudou-se ainda criança para a Itália onde realizou seus estudos, cursando Filosofia na Universidade de Milão. Lá, também participava de um grupo de teatro ativista chamado Teatro del Drago ${ }^{90}$. Entrou para o Odin Teatret em 1976 e seus principais tutores no grupo foram Tage Larsen - por quem foi "adotada" e de quem também foi esposa e as mulheres do grupo. $\mathrm{Na}$ época em que se juntou ao grupo, Barba não acompanhava mais os treinamentos dos atores, passando esporadicamente para assistir às pesquisas pessoais de cada um. Varley teve particular dificuldade com os exercícios vocais herdados de várias técnicas e, diante de um grave problema de voz, trabalhou por si mesma seguindo sua intuição na recuperação da capacidade vocal e desenvolvimento de uma técnica pessoal que a ajudasse a superar as dificuldades encontradas e pela qual é hoje bastante reconhecida. É professora, escritora e atua como organizadora de atividades e publicações. Também diretora, realizou trabalhos na Dinamarca, Japão Argentina, Brasil e Itália. Faz parte da ISTA desde 1990. É

\footnotetext{
${ }^{90}$ Em seu livro, Pedras d'água, ela conta essa primeira experiência com o fazer teatral (2010, p. 32-39).
} 
fundadora, junto a outras artistas, do The Magdalena Project ${ }^{91}$, rede de mulheres do teatro contemporâneo. Integrado a essa rede, promove o festival Transit, que acontece na sede do Odin Teatret, em Holstebro, do qual é diretora artística. Ainda é editora da revista Open Page, voltada à produção das mulheres no teatro. Suas publicações incluem vários artigos e ensaios em revistas especializadas e possui dois livros publicados: $O$ vento do oeste - novela de uma personagem(1997) e Pedras d'água - bloco de notas de uma atriz do Odin Teatret (2010).

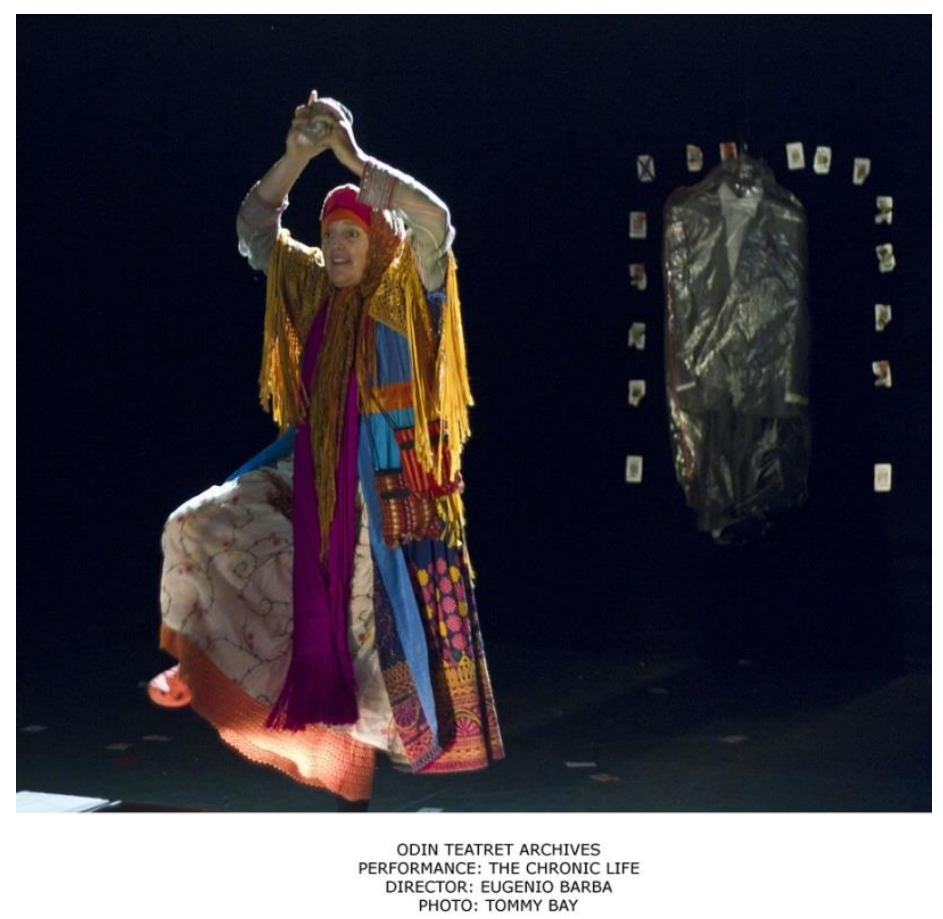

Figura 7. Julia Varley em A Vida Crônica. Foto Oficial do Odin Teatret.

\subsubsection{Jan Ferslev}

(1949 - DK) É músico, compositor, ator e professor. Ingressou no Odin Teatret, em 1987, tendo trabalhado em grupos teatrais antes disso, como guitarrista, compositor e ator. Sua formação musical inclui várias influências como rock, blues, jazz, música clássica e latina. É membro da Escola Internacional de Antropologia Teatral (ISTA). Seus cursos concentram-se no desenvolvimento da presença cênica de atores e músicos e são ministrados em todo o mundo. Participa do Festuge organizando um Cabaret que envolve músicos locais

\footnotetext{
${ }^{91}$ Essa rede tem como ramificações no Brasil o Encontro e Festival Vértice, que acontece bienalmente desde 2008 em Florianópolis e os Solos Férteis (2010) em Brasília. Em 2014, uma nova iniciativa foi tomada em Jundiaí, com o Magdalena $3^{a}$ Geração.
} 
e internacionais. É um dos instigadores da Odin's House Orchestra que apresenta concertos de tango, música dinamarquesa e latina-americana na cidade.

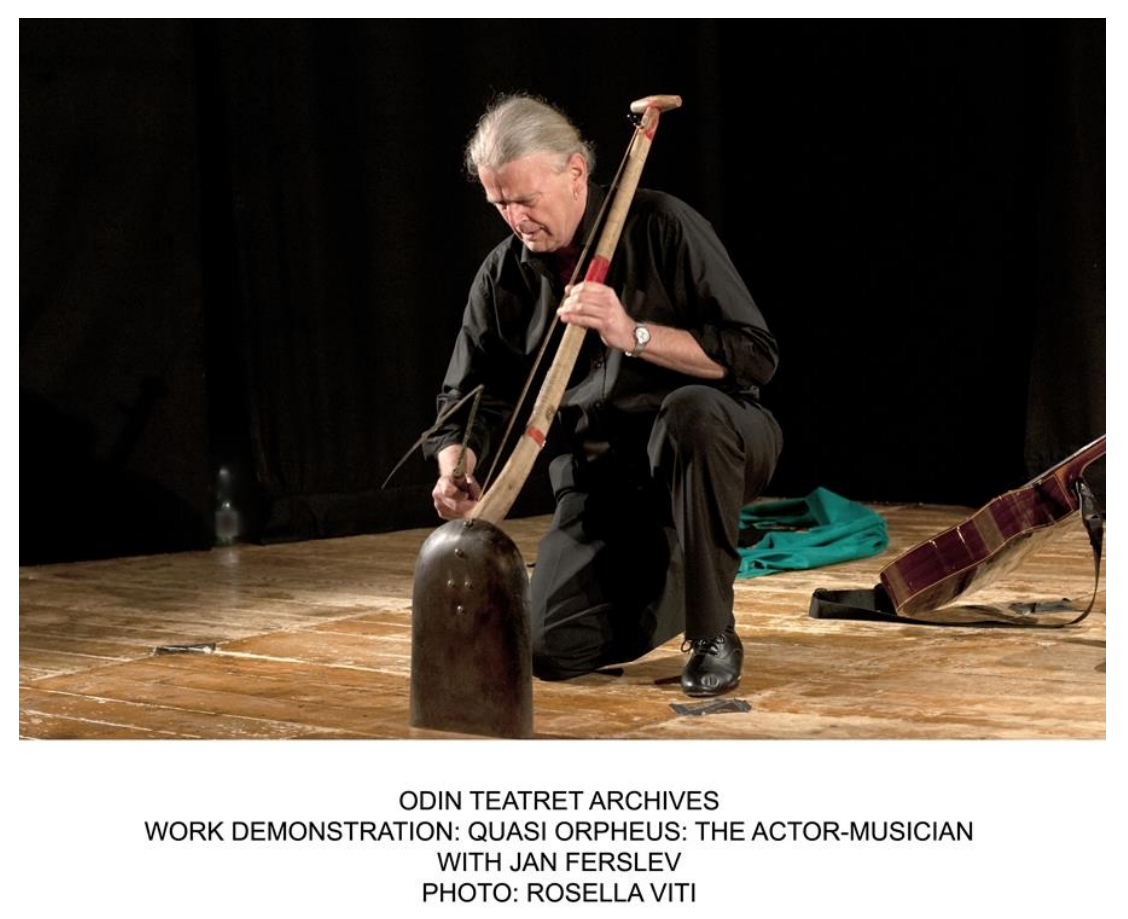

Figura 8. Jan Ferslev em demonstração de trabalho. Foto oficial do Odin Teatret.

\subsubsection{Frans Winther}

(1947 - DK) Compositor e músico de formação clássica, estudou no Conservatório de Música Nordjysk e compôs músicas para diversos grupos de teatro e orquestras. Ingressou no Odin Teatret em 1987, onde atua como músico, compõe e faz arranjos para as performances. Participa de outras atividades, como Festuge, ISTA, Theatrum Mundi ${ }^{92}$ e também dirige transformances $^{93}$ (dramatização de um meio social específico) em todo o mundo.

\footnotetext{
${ }^{92}$ Termo utilizado por Barba para os espetáculos interculturais preparados no final dos encontros ISTA. (PAVIS, 2008, p. 409).

93 Segundo a descrição da atividade no site do Odin Teatret, a transformance atua em espaços não convencionais, como escolas, paróquias, bairros, transformando o ambiente com a prática do teatro interferindo nas dinâmicas e relações habituais do local. O teatro é tomado na construção de vínculos colaborativos e dinâmicas artísticas. Disponível em: <http://www.odinteatret.dk/events.aspx>. Consulta em: 27/06/2014.
} 


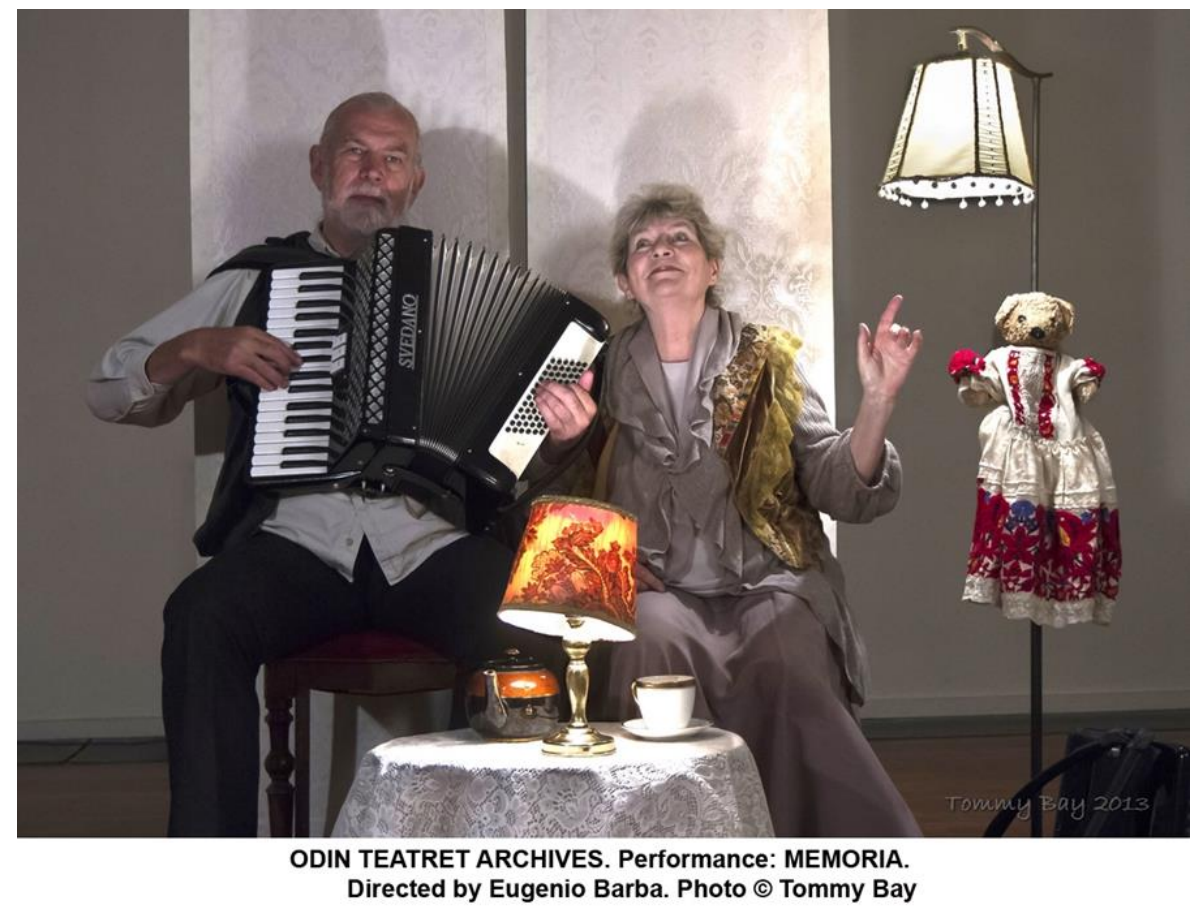

Figura 9. Frans Winther e Else Marie Laudvik em Memória. Foto oficial do Odin Teatret.

\subsubsection{Kai Bredholt}

(1960 - DK) Trabalhou como carpinteiro na construção de barcos. ${ }^{94}$ Começou a tocar música folk dinamarquesa nas ruas e em cabarés populares. Conta, em uma entrevista, ${ }^{95}$ que cantava sem técnica nenhuma, mas que experimentava várias formas de cantar e se preocupava em atingir grande volume de voz, para superar o barulho de um ônibus que passava de cinco em cinco minutos perto de onde se apresentava. Seus estudos, basicamente autodidatas, incluem vários gêneros de música europeia tradicional e folk. Juntou-se ao Odin Teatret em 1990, primeiramente como músico e compositor no espetáculo Itsi Bitsi e depois como ator sob treinamento com Rasmussen. Com o tempo, tornou-se organizador e diretor dos Barter e transformances. Kai Bredholt coordena e dirige performances de rua com vários grupos do mundo como, por exemplo, o espetáculo Parada de Rua, com o Lume de

${ }^{94}$ Esta não deixa de ser uma coincidência poética, pois, como registra Mariz (2008, p. 49) sobre observação de Nando Taviani, Barba refere-se a seus atores como "construtores de barcos" e são várias as menções a respeito da navegação e mares, como Além das ilhas flutuantes (1991) e A canoa de papel (1 $1^{\text {a }}$ ed.,1994), títulos de dois de seus livros. Lembremo-nos que Barba foi também marinheiro, em sua juventude.

95 Odin Teatret Archives, Training 09 Project - Fragments from Kai Bredholt's interview. Holstebro, 2009. Disponível em: <http://www.odinteatretarchives.com/odinstory/video-kai-bredholt-2009>. Acesso em: 07/06/2014. 
Campinas. Seu clown é o Van Gakk, um urso que toca uma sanfona. Ele também colabora com a comunidade local de Holstebro na criação de situações teatrais e construções de ambientes para realizar teatro ao ar livre. Desde 1992 é membro da ISTA.

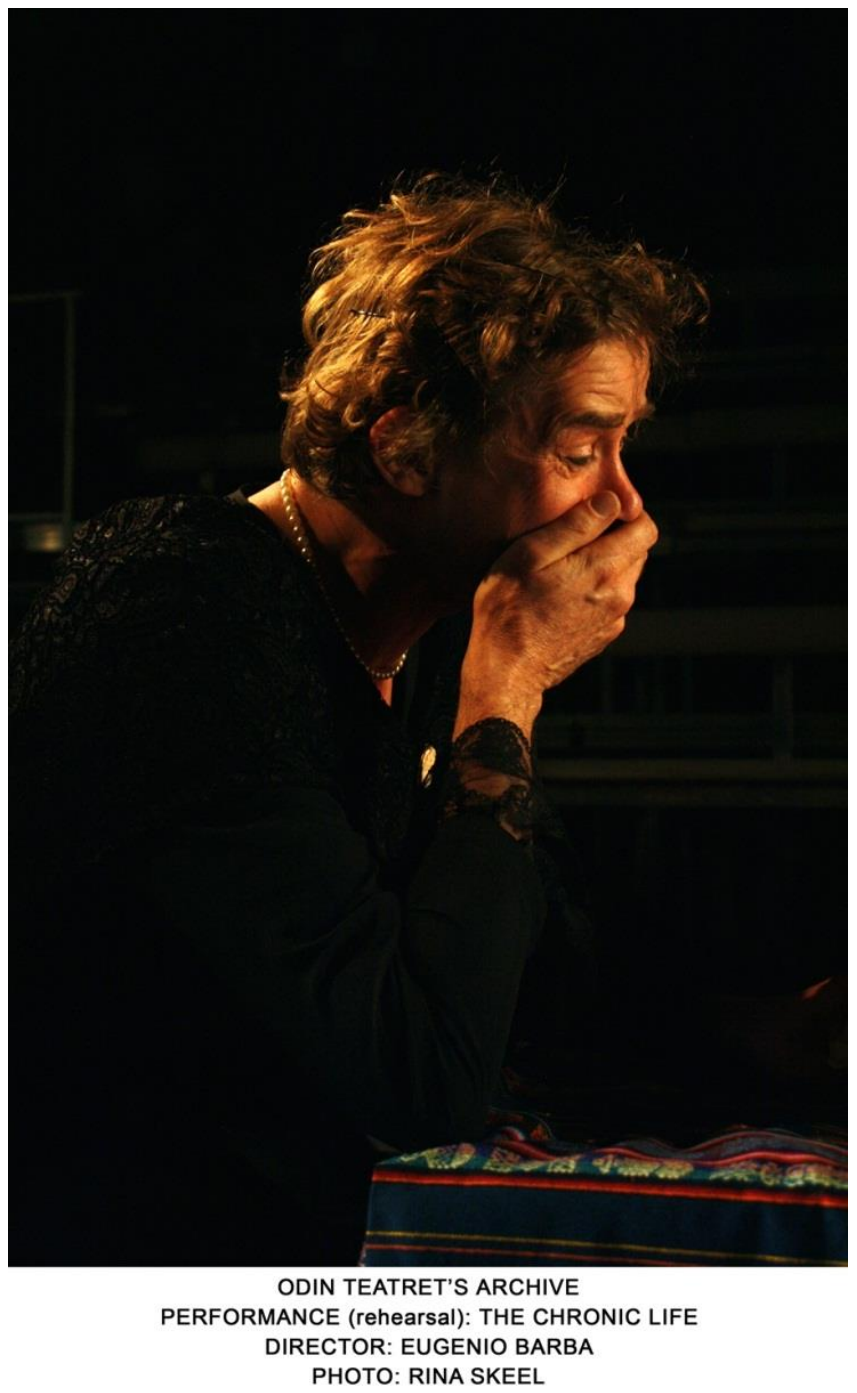

Figura 10. Kai Bredholt em A Vida Crônica. Foto oficial do Odin Teatret.

\subsubsection{Atores mais recentes}

Além dos atores acima, o ator e professor Donald Kitt (1964 - CAN), especialista em perna-de-pau, integra o grupo desde 2006. Kitt recebeu o treinamento nos moldes do Odin Teatret no Canadá com o ex-integrante Richad Fowler e depois com Tage Larsen, por quem foi dirigido em um trabalho solo. ${ }^{96}$ Também são integrantes atuais a atriz e professora Sofia

\footnotetext{
${ }^{96}$ Informações concedidas em entrevista a mim durante a Odin Week, 27/08/2013.
} 
Monsalve (1989 - COL) e a violinista atriz Elena Floris (1982 - ITA). Ambas são pupilas de Rasmussen no grupo Ponte dos ventos.

\subsection{0 horas com Eugenio Barba e Julia Varley}

Durante os anos de 2009 a 2012, sempre em dezembro, participei dos workshops $A$ Arte secreta do ator - Brasil: Como pensar através de ações, ${ }^{97}$ conduzidos por Eugenio Barba e Julia Varley em Brasília. É um encontro anual, com 30 horas de trabalho, e convivência full time com Barba e Varley, que tem como principal atividade o treinamento exclusivo de atuação e criação de dramaturgia com o diretor e a atriz, destinado a atores, diretores, acadêmicos e pesquisadores brasileiros e latino-americanos, que tenham experiência comprovada na área. Nos dois primeiros anos - 2009 e 2010 - a minha participação foi como atriz e nos anos seguintes, como observadora.

Esses encontros, que acontecem em uma chácara chamada Solar Guadalupe, na chapada da Contagem (DF), a $25 \mathrm{~km}$ do Plano Piloto, visam à transmissão direta da experiência dos mestres a artistas e acadêmicos das artes cênicas em formato de imersão, com trabalho continuado e convivência ininterrupta. ${ }^{98}$ Atividades como saraus e demonstrações de trabalho também fazem parte da programação, bem como palestras, espetáculos, lançamentos de livros e práticas alternativas de Tai Chi Chuan.

\footnotetext{
${ }^{97}$ Idealizado por Barba, juntamente à atriz e diretora Luciana Martuchelli, a primeira edição do curso aconteceu em 2008. Martuchelli é ainda colaboradora e tradutora do Odin Teatret. Disponível em: <http://aartesecretadoator.blogspot.com.br/>. Acesso: 01/02/2013. Nas primeiras edições a denominação Como pensar através de ações manteve-se, mas a partir de 2010, foi dada preferência para A Arte Secreta do Ator Brasil para referências ao curso. É adotada, então, essa última forma nas referências feitas aos cursos nesta dissertação.

${ }^{98} \mathrm{Na}$ bem-humorada definição de Martuchelli os cursos são ministrados em ítalo-portunhol por Barba. Mas tanto Varley, que domina muito bem o português, quanto Barba, se fazem entender perfeitamente.
} 


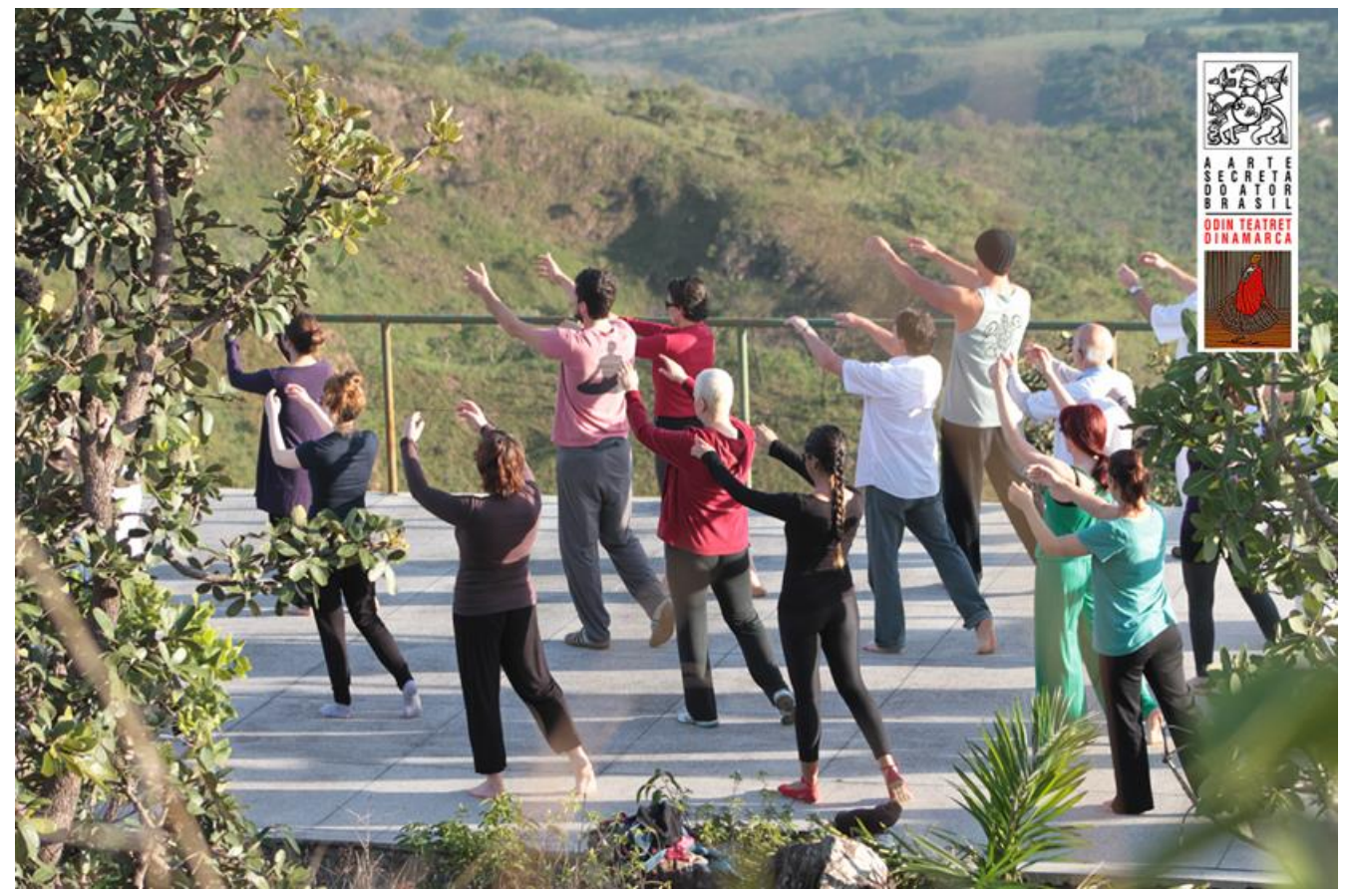

Figura 11. Prática de Tai chi chuan. A Arte Secreta do Ator - Brasil, 2011. Foto: Ricardo Calixto. ${ }^{99}$

Nas oficinas A Arte Secreta do Ator - Brasil, Barba e Varley estabelecem didáticas de treinamentos corporais com o intuito de trabalhar a presença do intérprete e uma clara ocupação com a transmissão da herança de anos de dedicação à prática e ao estudo do ofício. Os procedimentos propostos e experimentados nas respectivas oficinas técnicas com os mestres buscam o desenvolvimento da autonomia do intérprete, através do treinamento baseado em exercícios que possibilitam a vivência e reconhecimento dos princípios, pesquisa e seleção de materiais e escolha na composição cênica para os atores.

Durante as oficinas, a disciplina necessária ao treinamento do ator é enfatizada e aplicada no entendimento e preparação para o ofício. Atividades intensas, entre as $8 \mathrm{~h}$ e às $19 \mathrm{~h},{ }^{100}$ demonstram a necessidade de entrega e tempo para o desenvolvimento como ator. A técnica é tratada como sistematização da vontade, de procedimentos, só alcançada pelo treinamento. "Os exercícios do treinamento físico permitem desenvolver um novo

\footnotetext{
99 As fotos referentes aos cursos foram gentilmente cedidas para ilustrar esta pesquisa por Luciana Martuchelli, criadora e organizadora d'A Arte Secreta do Ator - Brasil, que detêm o direito de imagem sobre as mesmas.

${ }^{100}$ No Odin Teatret, as práticas iniciavam-se às 7h, na sala azul do teatro, (2010a, p.16; 218), e, diz Barba sempre que se lembra dessa época, "Pontualidade britânica para começar e sem hora para terminar..." (Anotação pessoal. A Arte Secreta do Ator-Brasil, Brasília, 2009).
} 
comportamento, um modo diferente de mover-se, de agir e reagir [...] Os exercícios físicos são sempre exercícios espirituais" (BARBA, 2009, p.141).

Em uma pesquisa teórico-prática na área de artes cênicas supõe-se que a última também assuma relevância no corpo da pesquisa (e da pesquisadora). O trabalho de campo aqui registrado revela-se nas práticas executadas com seus aplicadores e, posteriormente, na consequente aplicação em treinamentos individuais, coletivos, aulas ministradas e criação cênica. Sobre um assunto já tão estudado e dissertado, a possibilidade de estar com o fundador da Antropologia Teatral e a atriz do grupo, Julia Varley, justifica falar sobre os conceitos e a aplicação de técnicas transmitidas por eles. No entanto, os resultados só podem ser verificados na medida em que as técnicas são apreendidas e aplicadas. E há sempre, no caso dessa linha teatral, a personalização da metodologia. "O trabalho sobre si mesmo", destacado desde Stanislavski. Não existem fórmulas, mas sim indicações e caminhos que podem servir, desde que alguém se predisponha a segui-los. Já diz o próprio Eugenio Barba: "Vinagre no lugar de vinho - eis o que acontece com a transmissão de um método. Alguma coisa passa, mas [...] Só pode ser usado [...] como tempero.” (2010b, p.24). Barba irá salientar, durante os cursos, que são atalhos o que será transmitido. A assimilação e compreensão sobre o que falam dependem exclusivamente da dedicação e curiosidade de cada um para v(iv)er aonde aqueles podem desembocar.

Segue-se então um relato de experiência, tomando as palavras dos mestres e emprego dos "atalhos" adquiridos na vivência presencial dos cursos. Busca-se, nessa forma documental, trazer a experiência relatada em sua aplicação ao vivo, o que implica uma tradução da vivência, baseada nas muitas anotações dos quatro anos de cursos. As divisões em assuntos se estabelecem para uma maior compreensão da abordagem técnica dos princípios, mas é imprescindível acentuar que os mesmos, na prática, ocorrem de forma conexa, conforme os acontecimentos e a aplicação dos treinamentos. E, desde já, apontamos a constatação de que tudo o que Barba e Varley falam e fazem existe documentado pelos mesmos em seus muitos escritos, como a revisão de literatura interligada ao relato muitas vezes comprova. Há uma coerência intrínseca ao seu modo de arte-vida que é inseparável de suas expressões como artistas, escritores, pessoas. Um comportamento ético/estético que se traduz por anos de convivência em grupo, com riquezas de um pensamento/ação articulado segundo muitas referências e experiências entrecruzadas de um diretor e seus atores, movidos por uma incessante pesquisa de seu ofício, realizada no fazer, e que se evidencia no empenho em transmitir uma herança. Encerrando o capítulo, consideramos também a experiência na 
Odin Week na Dinamarca, principalmente no que diz respeito ao formato do encontro, outros workshops cursados e repertório assistido.

\subsubsection{Sobre o acontecimento: forma e conteúdo}

Os encontros em A Arte Secreta do Ator - Brasil seguem um formato pré-determinado, porém com mobilidade, segundo a percepção do grupo por Barba e Varley. Percebe-se também que, nos quatro anos consecutivos de participação, os próprios mestres foram moldando as abordagens e ajustando as estratégias pedagógicas, estabelecendo, na prática, uma configuração que permite pontuar, de forma organizada, todos os princípios. Vale destacar que esse formato de curso é inédito nas configurações pedagógicas aplicadas até 2008 na história do Odin Teatret nascido da vontade de Luciana Martuchelli, atriz e diretora de Brasília, de possibilitar a vivência daquilo que lia nos livros.

Nos pressupostos do workshop, os atores selecionados devem trabalhar uma pequena cena, antes do curso, para apresentá-la como "cartão de visita" a Barba e Varley e aos outros participantes. Um texto ou tema é indicado previamente, ${ }^{101}$ e todos devem levar cópias do trecho escolhido, bem como breves informações sobre o(s) autor(es), para entregar aos docentes. As cenas serão trabalhadas ao longo dos dias com o diretor e a atriz e vão se transformando na medida em que, na transmissão prática dos ensinamentos, os conteúdos propostos pelo curso são aplicados. São eles. ${ }^{102}$

1. Elaboração da dramaturgia do ator a nível orgânico ou dinâmico - as ações físicas e vocais;

2. Relação entre partitura orgânica/dinâmica e a estrutura narrativa;

3. Relação entre a dramaturgia do diretor e do texto;

4. Relação entre dramaturgia do diretor, do escritor e do ator;

101 2008: Casa de Bonecas, de Ibsen; 2009: De repente, nas profundezas do bosque, de Amos Oz; 2010: A flor das idades e poesias de Omar Khayyam; 2011: "Histórias de Amor", 2012: "Uma mulher (ou um homem) sorridente, carregando um fardo sobre seus ombros, navega até o abismo." Em ANEXO A encontra-se a orientação para 2010, como exemplo. Em 2013, apesar de não estar presente, tive acesso ao tema: "Arquitetura do ocaso". Disponível em: <http://aartesecretadoator.blogspot.com.br/p/informacoes-sobre-ultima-edicao2013.html>. Acesso em: 30/04/2014.

${ }^{102}$ Esses conteúdos são apresentados nas divulgações dos cursos, disponíveis em:

<http://aartesecretadoator.blogspot.com.br/>. Acesso em: 07/05/2012. 
5. Técnicas cotidianas e extracotidianas; ${ }^{103}$

6. Diferença entre movimento e ação;

7. Imobilidade estática e dinâmica;

8. A energia no espaço e a energia no tempo;

9. Técnica da montagem para diretores;

10. A percepção do diretor e a percepção do espectador;

11. A participação em um processo de preparação, criação, dramaturgia, direção e montagem teatral sob a metodologia e tradição do Odin Teatret com Eugenio Barba e Julia Varley.

A abertura se dá na noite anterior da ida para o Solar, com palestras de Barba e/ou apresentações cênicas de Varley. ${ }^{104}$ No dia seguinte, deslocamo-nos cedo para o local do curso, do qual não sairemos mais até a hora de ir embora. Faremos um apanhado geral da programação vivida em quatro anos, pontuando as especificidades de cada ano, quando citadas.

No primeiro dia, há apresentação das cenas dos atores participantes e Barba e Varley começam a trabalhar diretamente sobre as mesmas, aplicando e dissertando sobre os princípios do trabalho do ator a partir do que assistiram. Apesar de essa dinâmica ser aparentemente determinada, nos quatro anos em que participei nenhuma vez Barba se repetiu literalmente na forma de abordagem, apesar de estar sempre falando sobre a mesma coisa. Sua

103 "As técnicas extracotidianas do corpo consistem em procedimentos físicos que se mostram fundados na realidade que se conhece, mas segundo uma lógica que não pode ser reconhecida imediatamente." BARBA \& SAVARESE, 2012, p. 28.

104 Patrícia Furtado de Mendonça oferece um apanhado das atividades: "Nas edições anuais realizadas em dezembro de 2008, 2009 e 2010, Eugenio Barba deu suas palestras seguidas de debates; Julia Varley apresentou as demonstrações de trabalho $O$ eco do silêncio e $O$ tapete voador, além do espetáculo Matando o tempo: 17 minutos na vida de Mr. Peanut; foram lançados três livros de Barba - A canoa de papel: Tratado de Antropologia Teatral; Queimar a casa: Origens de um diretor; e Teatro: Solidão, ofício, revolta-e um livro de Julia Varley - Pedras d'água: Bloco de notas de uma atriz do Odin Teatret". Disponível em: <http://www.questaodecritica.com.br/2011/11/a-arte-secreta-do-ator-teoria-e-pratica-no-brasil/>. Acesso em: 24/04/2014. Em 2011, a abertura contou com a palestra de Barba um "bate-papo" com o diretor Aderbal FreireFilho. Julia Varley apresentou $O$ irmão morto. Em 2012, o tema da palestra foi "Tecer relações, o ator de um teatro-laboratório" e foi apresentada a peça Ave Maria, com Julia Varley além do filme A conquista da diferença de Erik Exe Christoffersen/Odin Teatret Film. Houve ainda o lançamento do livro A Arte secreta do ator - um dicionário de Antropologia Teatral de E. Barba e N. Savarese. Em 2013, a abertura foi com a palestrademonstração $O$ diálogo das técnicas - o Ator- bailarino com Julia Varley e a Cia Mundú Roda. Disponível em: <http://aartesecretadoator.blogspot.com.br/>. Acesso em: 24/04/2014. 
capacidade de criar metáforas, analogias, exercícios para exemplificar seu entendimento do ofício do ator é percebida ao vivo e em seus escritos. Como constata Masgrau, ${ }^{105}$

O trabalho escrito de Eugenio Barba é um laboratório de conceitos. Entre os numerosos textos e a aparente variedade de assuntos tratados, existe, no seu trabalho, uma série de linhas de força que o estruturam e o amalgamam em um todo coerente. Essas linhas de força são compostas por uma série de conceitos que Barba retoma e elabora de um texto para o outro. Esses conceitos se movem por seus escritos através de inumeráveis peripécias intelectuais.

Varley já ressalta essa capacidade, notada nos inúmeros seminários que acompanha junto ao diretor, quando ele conta as mesmas histórias, mas sempre de maneira diferente, "como se quisesse exprimir um significado que ainda o escapava." (VARLEY, 2010, p. 207). Notamos, assim, um constante desafio de Barba para se reinventar, não ter certezas e se acomodar. $\mathrm{O}$ fato de haver pessoas que já tinham acompanhado o curso gerou comentários como "Estou inventando tudo aqui para não me repetir. Eu não sei o que estou fazendo. Vocês me dão o caminho. ${ }^{106, "}$ Varley (2010, p. 202) também vai pontuar essa característica do diretor, ao observar que Barba atém-se principalmente na concretude do que lhe é oferecido para trabalhar. Essa, aliás, é uma característica notada em diretores do séc. XX, que tornarão o ator aliado da criação, e não um elemento de execução de ideias pré-concebidas para a encenação.

O segundo dia é aberto com a introdução ao trabalho vocal, com Varley. Se o tempo está bom, trabalhamos em um belo platô ao ar livre, debruçado sobre as montanhas pelo qual se chega por uma trilha de terra, até o sol se tornar escaldante. ${ }^{107}$

105 MASGRAU, Lluís. Index of concepts in Eugenio Barba's writings. s/d, s/p. (Tradução nossa.) Original: "Eugenio Barba's written work is a laboratory of concepts. Beyond the numerous texts and the apparent variety of subjects dealt with, there exists in his work a series of inner lines of strength that structure and amalgamate it in a coherent whole. These lines of strength are composed of a range of concepts that Barba takes up and elaborates from one text to another. These concepts move through his writings via innumerable intellectual peripetia." Disponível em: <http://www.odinteatret.dk/media/217060/INDEX\%200F\%20CONCEPTS\%20Sept\%2010\%20-\%20en.pdf>. Acesso em: 01/03/2014.

${ }^{106}$ Anotação pessoal, A Arte Secreta do ator-Brasil, Brasília, 2010.

${ }^{107}$ Via de regra, Varley comenta, entre divertida e irônica, ao nos ver suando e bufando: "Eugenio, vamos subir, que os brasileiros não aguentam o sol”. Anotação pessoal. A Arte Secreta do ator - Brasil, Brasília, 2009 a 2012. 


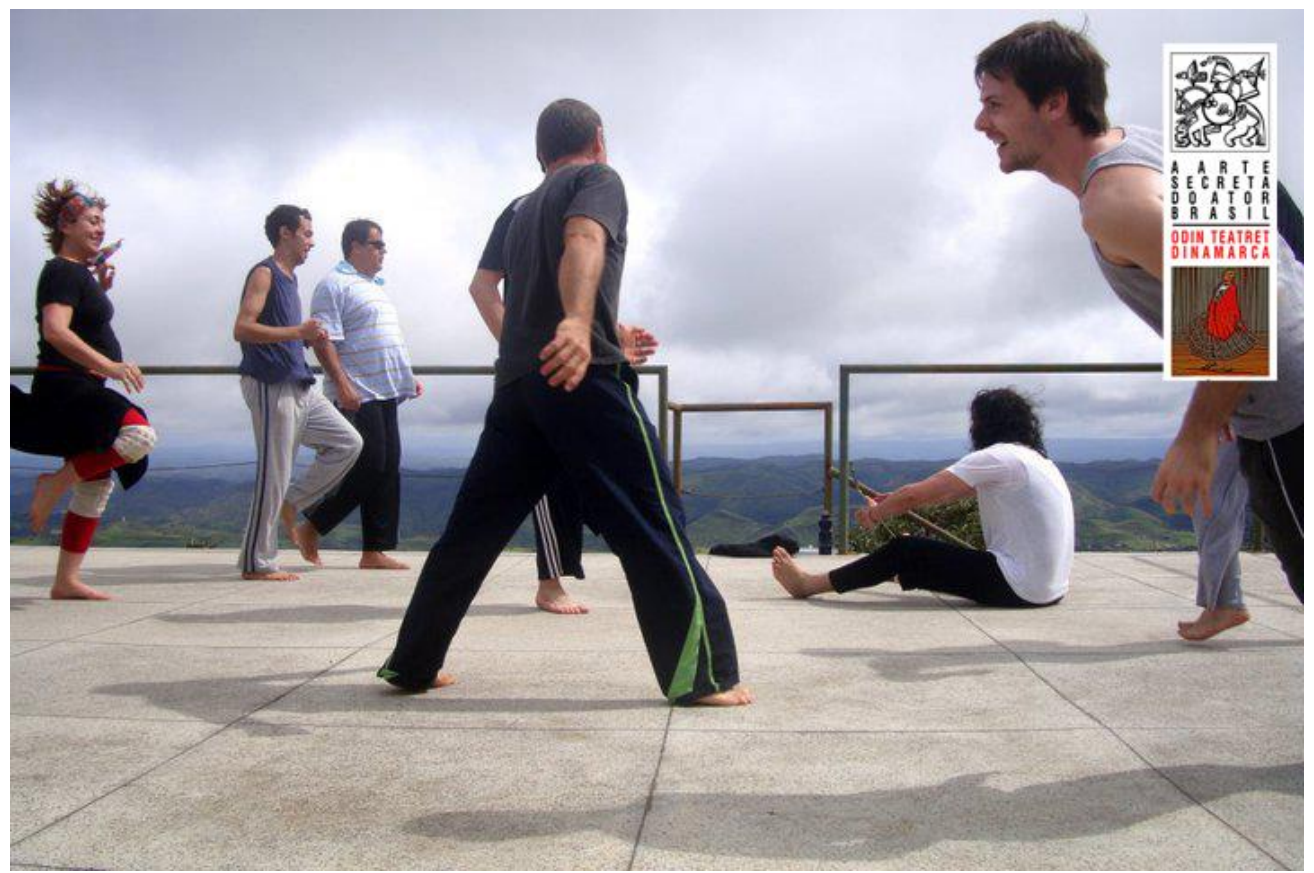

Figura 12. Brincar, marchar, caminhar, ao chão... A Arte Secreta do Ator - Brasil, 2010. Foto: Edu Barroso.

Barba fica a um canto, sentado, apreciando atentamente os exercícios e tomando sol, coisa que, segundo ele, adora. Eventualmente interfere, mas é Varley quem comanda a ação. Esses exercícios serão descritos no capítulo três de forma detalhada. Mas ressaltamos, desde já, que Varley sempre conjuga a voz com o corpo, propondo que a lancemos no espaço, para fora, e não contenhamos o cansaço, deixando o ar sair, mesmo que a voz se torne "estranha" e evitando, sobretudo, a "tendência masoquista do ator em não respirar"108. Depois do treinamento de voz, na qual é também construída uma música com fragmentos propostos por vários atores, em um exercício regido por Varley, ${ }^{109}$ Barba faz considerações sobre o que o trabalho despertou nele, trazendo princípios que podem estar ligados ao trabalho vocal ou inserindo e "costurando" conceitos, mas principalmente enfatizando o "fazer fazendo". Na parte da tarde, a continuação tem sequência com o trabalho com bastões e dura a tarde toda. Esse lidar com o elemento serve para que o ator perceba as tonicidades musculares em seu corpo e também insere as elaborações de Barba e Varley sobre a relação cênica com objetos.

No terceiro dia, Varley retoma o trabalho vocal, reforçando os exercícios do dia anterior e inserindo novos. A essa altura, os atores já possuem um repertório de ações vocais e físicas, provenientes do trabalho sobre suas cenas, das canções e das partituras criadas a partir

\footnotetext{
${ }^{108}$ Anotação pessoal. A Arte Secreta do Ator - Brasil, Brasília, 2009.

${ }^{109}$ Ver p.133, exercício 20.
} 
de diversos exercícios como bastão, partituras com as mãos, formas de pisar, de falar o texto etc.

Acontece, então, um longo trabalho de exaustão sobre esse material, que chamei em minhas anotações de "composição de materiais"110, em que os atores trabalham initerruptamente aplicando diversos estímulos baseados, principalmente, em imagens, coordenado por Varley sendo que, ao mesmo tempo, o ator recebe orientação para fixar as variações descobertas. ${ }^{111}$ Essa capacidade, de ao mesmo tempo improvisar sobre o que está sendo pedido e fixar suas escolhas, é destacada como primordial nesse tipo de pensamento com o corpo (o "pensar através de ações") e só pode ser adquirida através do treinamento sobre essa condição: desenvolver a possibilidade da criação ao mesmo tempo em que seleciona o que é importante e "vivo" e as fixa. Selecionar e perceber "o que funciona" provém do treinamento nessa linha de condução do trabalho do ator. Essa seleção é intuitiva, mas a intuição decorre também do tempo de trabalho com esse tipo de linguagem, baseada nos princípios treinados na fase pré-expressiva. Sobre essa compreensão foram importantes as participações como observadora, pois se tornam claros os entendimentos (e incompreensões) dos atores a respeito dos princípios, as tendências de cada um e escolhas na seleção do que formará as partituras. Varley propõe variações de ritmo, densidade, volume e direções, bem como referências a estados sugeridos por personagens antológicos, como Medéia, Hamlet, entre outros. É um trabalho potente, que mune de qualidades diversas a execução da partitura. Um processo que comporta descobrir possibilidades de trabalhar sobre o material criado, permitindo as mais diversas variações, mas sempre aplicadas à partitura inicial.

Então, no período da tarde do terceiro dia, assistimos a vídeos de treinamento dos atores do Odin Teatret, nos idos de 1970, seguidos de explicações e comentários sobre a aplicação e objetivos do treinamento (em 2009) ou acompanhamos os ensaios do espetáculo de Varley (2010 e 2011), processo especial que será comentado em 1.3.3, ou participamos dos ensaios do "espetáculo" final com os atores (2012). Geralmente há atividades noturnas

\footnotetext{
${ }^{110}$ Ver p. 135, exercício 23.

111 A primeira vez que realizei esse exercício, em 2009, tive uma forte reação emocional que até hoje é mobilizadora ao me lembrar de como me senti. Ao seu término, sentei-me no centro do salão, já vazio e, percebendo-me em um vórtice de força, chorei compulsivamente de alegria e prazer, reconhecendo o corpo pulsando em potência, a exaustão muscular que revelava desbloqueios, o encontro com possibilidades que me tornavam viva e instigada. Como observadora, nos anos de 2011 e 2012, a experiência também foi muito física, pois sensações de temperatura do ambiente, deslocamentos de ar, causados pela movimentação e respiração dos atores trabalhando, impulsos visíveis nos corpos, causaram-me sensações corporais e reações cinestésicas de reconhecimento, ou, quando não havia "verdade" na execução, desconfiança e repúdio.
} 
organizadas por Martuchelli e equipe que incluem saraus, apresentações especiais de grupos de Brasília coordenados e/ou dirigidos por ela.

No último dia há uma apresentação a partir dos materiais selecionados das cenas dos atores e trabalhados durante o curso. Em 2009, o trabalho foi realizado em duplas, conjugando as partituras pessoais com um trecho do texto de Amoz Oz, delegado por Barba, a cada dupla. Nesse ano, entendi o princípio da omissão/redução, pois, em minha cena, toda a partitura física foi cortada e Barba colocou-nos, eu e meu par, sentados, sem poder exteriorizar nada em ações, mas com o objetivo de mantermos todos os impulsos internos do que havíamos feito na sua execução. ${ }^{112}$ Em 2010, realizamos uma improvisação em grupo ao ar-livre, dirigida por Barba, que foi filmada para enviar como um presente a um amigo que estava fazendo aniversário. A partir de 2011, Barba e Varley ensaiaram com todos os atores um "espetáculo", apresentado no final do workshop para convidados. Barba sempre cria um tema para a apresentação e dirige os atores cortando e/ou ressignificando suas ações, interligandoas segundo o tema estabelecido. É um momento bastante tenso, porém divertido, pois Barba tem ideias alucinantes e as resolve tecnicamente, como quando pediu que um ator "voasse" de um lado para o outro da sala. Disse que precisava dele imediatamente do outro lado, após uma cena e para isso, o ator deveria bater uma palma e correr o mais rápido possível para onde o diretor indicou. E só quando ele estivesse do outro lado, a cena poderia continuar de onde parou. ${ }^{113}$ Os "espetáculos" contemplam a forma de montagem ${ }^{114}$ exercida por Barba na sua direção e criação de dramaturgia. Varley também colabora no processo final, ensaiando partes específicas com os atores, como em 2012, na encenação cujo tema foi um casamento, enquanto Barba se ocupava com o "coro" masculino, ela trabalhava com as mulheres.

Os encontros se encerram com um jantar festivo, a entrega de certificados e fotos oficiais.

\footnotetext{
${ }^{112}$ Lembro-me de ter ficado confusa quando o diretor pediu que cortássemos todas as ações, pois eu tinha a percepção de que nossa partitura havia ficado muito fluida e coerente. Na primeira execução que fizemos sentados, Barba pediu: "Deixem as informações somente na coluna vertebral" e Varley, após a apresentação, alertou: "Não percam o tom que vocês haviam achado, mantenham o segredo, as relações encontradas na ação." Anotações pessoais, A Arte Secreta do Ator - Brasil, Brasília, 13/12/09.

113 Anotação pessoal. A Arte Secreta do Ator - Brasil, 16/12/2012.

${ }^{114}$ Ver p. 107 deste trabalho.
} 


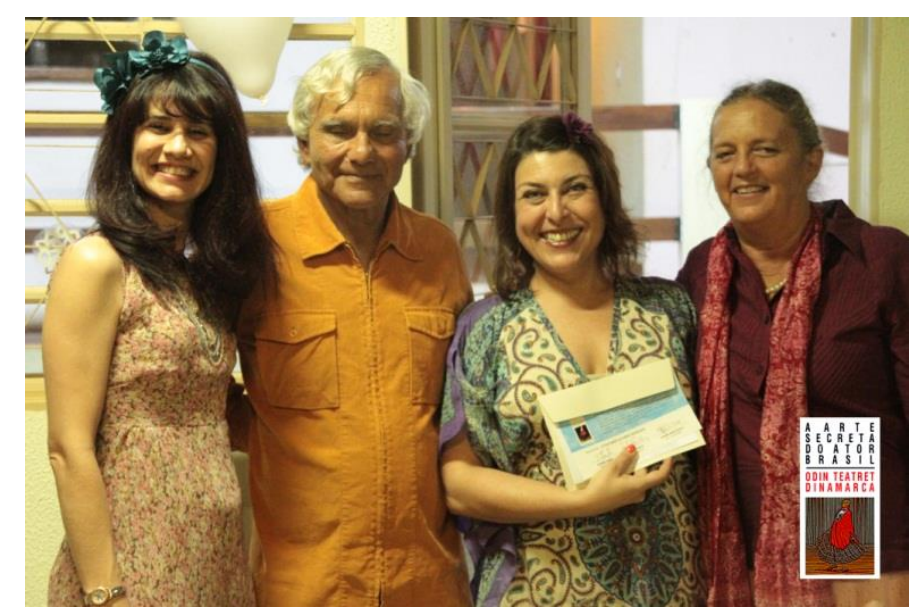

Figura 13. Entrega de certificado. A Arte Secreta do Ator - Brasil, 2012. Com Luciana Martuchelli, Eugenio Barba, Leticia Olivares e Julia Varley. Foto: Ricardo Calixto.

\subsubsection{Sobre os princípios}

Nos treinamentos aplicados, a sequência durante os quatro dias visa munir os atores com os já comentados "atalhos" e é categorizada por Barba como exemplos, pois cada tipo de trabalho e suas descobertas, e consequente apropriação por parte dos atores, só pode acontecer depois de longos períodos de aplicação. Estabelece, inclusive, a quantidade, como p. ex., no exercício de "contar sílabas da ação", que será descrito à frente. Comenta que essa incorporação da proposta e dos princípios contidos, exige uma hora por dia, durante o ano todo, para que o "pensamento com o corpo" crie raízes. ${ }^{115}$

A partir daqui, isolamos as conceituações dos princípios desenvolvidos nos treinamentos, segundo as anotações presenciais e em diálogo com a literatura dos autores.

Eugenio Barba anuncia na apresentação da oficina em 2011: "No teatro não existem verdades, a única coisa que existe é a eficácia do ator em relação ao espectador."116. O termo eficácia parece estranho à arte do ator, mas é amplamente utilizado por Barba para objetivar um resultado prático. $\mathrm{Na}$ literatura achamos, ainda, a palavra aplicada para ressaltar um de seus papéis, como diretor: o de investigador da eficácia cênica, como primeiro espectador (2010a, p.100). Em outro texto, presente no mesmo livro (p.102), pergunta: "Que processos,

\footnotetext{
115 Anotação pessoal. A Arte Secreta do Ator - Brasil, 08/12/2011.

${ }^{116}$ Idem.
} 
técnicas ou princípios o ator deve utilizar para tornar sua ação eficaz diante do espectador? Isso pode ser aprendido? Como?".

A busca do corpo em vida ${ }^{117}$ para o ator, fator que induz à presença cênica, é documentada por vários estudiosos do século XX. Segundo Eugenio Barba (2010a, p.103), ao questionar o sentido do teatro na sociedade, os reformadores ${ }^{118}$ inventaram novos pressupostos técnicos e ingressaram na pedagogia ao estabelecer exercícios que permitiriam ao ator aprender a "compor e a dirigir uma 'vida cênica' genérica, razão pela qual sua técnica existe." Os modelos anteriores do fazer teatral não respondiam à questão sobre como dar o primeiro passo no palco para causar a atração imediata do espectador.

Nos cursos, Barba sempre salienta que a técnica para o ator corresponde ao trabalho do artesão, no qual o conhecimento é ativo e prático. O saber fazer implica em um conhecimento que se molda na observação, imitação, repetição, absorção e por fim, na personalização do que é apre(e)endido. O conhecimento incorporado é o saber fazer; "saber tácito" que se aprende fazendo, ao que exemplifica contando sua experiência como soldador, e credita, também, a seu primeiro mestre de solda, um aprendizado ético do ofício que o impregnará por toda a vida. ${ }^{119}$

Os atores do Odin Teatret desenvolveram autodidaticamente práticas corporais decupando as ações espontâneas em procedimentos que quebrassem seus próprios clichês de movimentação. Diz Barba: "O teatro não tem a ver com espontaneidade. É como uma expedição antropológica a si mesmo que tem a ver com exterioridade. Signos eficazes que golpeiam, acalentam ou desorientam a expectativa do espectador." ${ }^{120}$ Criar, no próprio corpo, pacotes de mudanças de energia que, aparentemente, indicam uma unidade, mas são ações decupadas em mudanças de tonicidade. O termo energia é recorrente para especificar um estado ou condição ligados diretamente à criação de tensões musculares específicas. Barba

\footnotetext{
${ }^{117}$ Corpo em vida, corpo dilatado são expressões usadas por Barba para designar a construção pelo ator de um corpo "extracotidiano", i.e., modelado "segundo princípios diferentes dos da vida cotidiana". (BARBA, 2009, p. 25).

118 "Aqueles pouquíssimos a quem chamamos de rebeldes, heréticos ou reformadores do teatro (Stanislavski e Meyerhold, Craig, Copeau, Artaud, Decroux, Brecht e Grotowski) são os criadores de um teatro de transição." (ibidem, p.19).

${ }^{119}$ Essa história pode ser conferida mais a fundo no capítulo: Quem fez de mim o que sou, no livro Queimar a casa - origens de um diretor. (BARBA, 2010b, p.144).
}

${ }^{120}$ Anotação pessoal A Arte Secreta do Ator - Brasil, 11/12/2010. Revisada por Barba em 2011. 
dedica um capítulo inteiro para conceituar essa palavra no trabalho do ator, denominado: "A energia, ou seja, o pensamento." (2009. p. 84). A certa altura, encontramos: "Energia é uma temperatura-intensidade pessoal, que o ator pode individuar, despertar e modelar." (p. 103). ${ }^{121}$

Segundo ele, o ator fala três idiomas: o físico (ações e o dinamismo), o da voz (sonoridade da fala) e o do texto (palavras). ${ }^{122}$ Os "idiomas" podem ser trabalhados de forma separada e, ao se juntarem, produzir diferentes significados, compondo a dramaturgia orgânica ou dinâmica, que diz respeito aos aspectos básicos de composição do trabalho do ator (BARBA, 2010b, p. 39).

Em sua pesquisa, Barba (2009, p. 22) chegou aos princípios pré-expressivos que devem modelar energias, sendo esse trabalho, para o ator, um procedimento técnico. Esses princípios "permitem gerar a presença teatral, o corpo em vida do ator capaz de fazer perceptível àquilo que é invisível: a intenção."

Vejamos os princípios, chamados por Barba de "princípios-que-retornam" (2009, p.30), por serem identificáveis em várias tradições de dança e teatro, mapeadas por ele:

- Equilíbrio extracotidianol equilíbrio de luxo. Barba irá reconhecer o equilíbrio extracotidiano nas formas do teatro oriental (Nô, Kyogen, Kabuki), nas danças asiáticas e no Ballet clássico, bem como em sistemas de mímica e na dança moderna, relacionado, nesse caso ao off-balance e às quedas e recuperações. Caracteriza-se por provocar um "desequilíbrio", segundo diferentes elaborações de tensões musculares que geram instabilidade, forçando uma condição formalizada, estilizada e codificada (BARBA, 2009, p. 35 a 44). Esse princípio proporciona, como operação para o ator, a transferência de peso, mudança de eixo e provoca a desestabilização da noção espacial do espectador.

- Oposições. ${ }^{123}$ As oposições são "forças contrapostas [...] que agem simultaneamente" e que, ampliadas, levam à desejada dilatação, ou seja, tornam-se visíveis, apesar de não necessariamente reconhecíveis, para o espectador (BARBA, 2009, p. 48, 49). Ligada ao entendimento da oposição está a complementaridade, quer dizer, considerar a ação oposta como uma ação complementar à executada, que pode ou não ser realizada na composição.

\footnotetext{
${ }^{121}$ Cf. também BARBA \& SAVARESE, 2012, pg. 19; 28; 72-91.

${ }^{122}$ Anotação pessoal A Arte Secreta do Ator - Brasil, 09/12/2009; Cf. BARBA, 2010b, p. 39.

${ }^{123}$ Cf. também BARBA \& SAVARESE, 2012, p. 19-21.
} 
Podemos pensar em oposições também na ação vocal: "falar algo horrível com voz de mel", exemplifica Barba. ${ }^{124}$ Ainda, Varley trabalhará com esse princípio aplicado a exercícios de voz e ação corporal, p. ex., enquanto a voz vai para o agudo, a ação é para baixo, como sentarse ou se abaixar e vice-versa. Outra forma possível de aplicar esse princípio é fazendo internamente a ação oposta à externa. Usando o exemplo de abaixar-se, a intenção interna seria de ir para cima, gerando microrreações musculares que impactam as sensações do espectador.

- Estilização. Chamada por Barba (2009, p. 50, 51) de "incoerência coerente" esse princípio é destacado como a capacidade de transmitir coerente e sinestesicamente uma "segunda natureza" artificial, porém orgânica. A estilização se encontra nas bases das manifestações artísticas orientais, criando signos passíveis de entendimento, apesar de não fazerem necessariamente sentido. Aquilo que se caracteriza como "deformações", ou seja, posturas que levam a um corpo extracotidiano, como as posições do Ballet clássico, por exemplo, também estão nos aspectos da estilização. Barba se refere à "incoerência coerente" ainda como uma forma de "colorir", saber juntar as ações, atribuindo diferentes impressões rítmicas a elas de forma que a "linguagem física injete outra percepção no espectador.",125

- Omissão. ${ }^{126}$ Como ressalta Bonfitto (2009, p. 78), Barba passa por várias referências para exemplificar esse princípio, citando Decroux, entre outros, em um processo de "absorção da ação" que serve para reter e ao mesmo tempo ampliar as forças das ações, tornando o corpo vivo em cena, ainda que na imobilidade. Varley (2010, p. 89) chama esse princípio também de redução, e destaca sua qualidade de limpar os excessos ilustrativos. No exercício do clip, que será descrito à frente, ao pedir para fazer um resumo das ações, notamos que Barba está também trabalhando esse princípio a fim de obter a síntese dramatúrgica (BARBA \& SAVARESE, 2012, p. 195), resultado de omissões e cortes para reforçar a presença cênica do ator. É também um exemplo quando pede que os atores omitam os braços em suas ações, deixando os impulsos visíveis apenas na coluna.

- Equivalência. Esse princípio será caracterizado pela qualidade de transposição, ou seja, mesmo sendo diferente entre si, um instrumento ou intervenção possuirá o mesmo valor, produzirá efeitos iguais ou cumprirá função idêntica (BARBA, 2010b, p. 59). A equivalência

\footnotetext{
${ }^{124}$ Anotação pessoal. A Arte Secreta do Ator - Brasil, Brasília, 09/12/2011.

${ }^{125}$ Idem, 12/12/ 2010.

${ }^{126}$ Cf. também BARBA \& SAVARESE, 2012, p. 22- 23.
} 
permite a quebra de automatismos ao produzir uma ação real, mas não necessariamente realista (2009, p. 59).

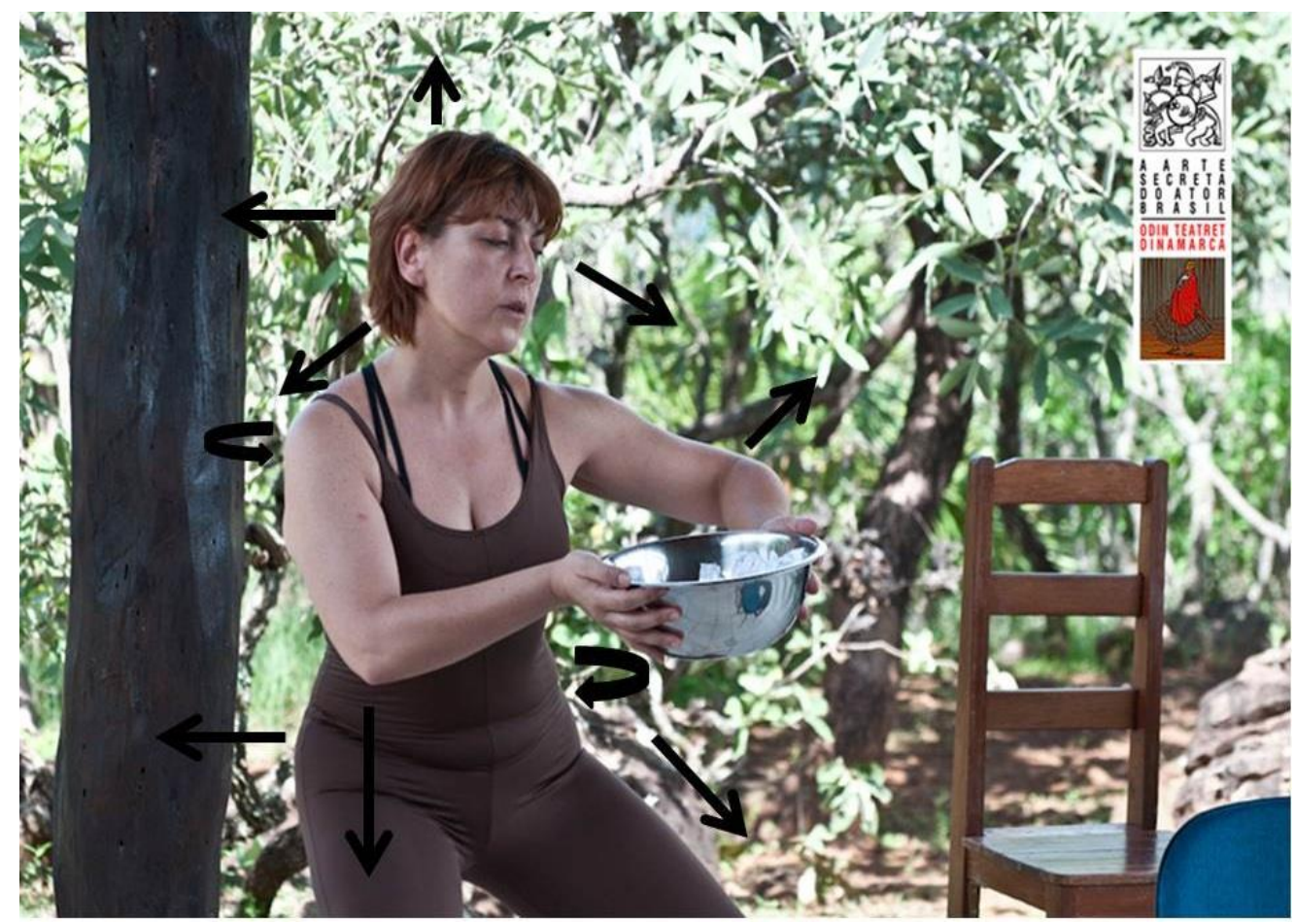

Figura 14. Oposições. A Arte Secreta do Ator - Brasil, 2013. Foto original: Edu Barroso. Intervenções: Leticia Olivares.

Podemos pensar em todos esses princípios também como operadores, passíveis de aplicação técnica de estratégias compositivas de uma partitura. Durante as improvisações, o ator pode aplicá-los para conformar suas ações, atribuindo uma série de qualidades, surpresas, decorrências e modos de fazer que ecoem na sua presença e relação com os espectadores.

As ações físicas têm a função de dar vida e, depois, transmitir vida para os espectadores através de impulsos que se tornam visíveis. Ser um cisne, que desliza aparentemente calmo e suave sobre o lago, enquanto suas nadadeiras estão a toda velocidade embaixo da água (BARBA, 2009, p. 90). Ao ator cabe a capacidade de defender o impulso inicial da ação e imperceptivelmente preparar a próxima. Manter a transparência do impulso com a sabedoria da técnica e manipular a expectativa do espectador. A essência da metodologia e expressão de um ator está na capacidade de, sendo origem de suas ações, articulá-las em signos objetivos, apesar da subjetividade de sua matriz (2010a, p.42).

Barba trabalha com as ações como palavras, que podem ser divididas em sílabas. Exemplifica: em uma palavra, se mudarmos alguma letra, estaremos mudando a mesma, a 
ver:, ovo não é a mesma coisa que oco e, se ainda, a articularmos "opo" como um nonsense, haverá uma deformação, significando perda de entendimento sobre o que queremos dizer, o que corresponde à perda de precisão da ação. Assim, é necessário rigor com as sílabas das ações. ${ }^{127}$ Barba caracteriza a ação como a menor unidade que o ator pode controlar. E o ator tem que conhecer profundamente cada uma de suas ações. Para isso ele propõe que contemos as sílabas das ações, percebendo onde o impulso muda, para conhecer a "dicção das formas físicas", diferentes segmentos dos movimentos. Barba, durante os cursos, pede para que cada ator descubra as sílabas de suas ações na cena, identificando exatamente como são seus desenhos, separando-as com micropausas para dominar as transições, que são o que geram os novos impulsos para a próxima ação. Para facilitar o reconhecimento das transições, Barba bate palmas, marcando a mudança de uma ação para outra, em um exercício para desenvolver o reflexo e a percepção de transição do ator. Cada mudança de tonicidade deve ser estudada por meio dessa segmentação, que é trabalhada através da descoberta das sílabas dos movimentos. Devem ser achados também os momentos de imobilidade, que paradoxalmente devem conter um dinamismo máximo. Nesse momento de contenção reconhecemos o nominado sats. Varley (2010, p. 63) define o sats, terminologia escandinava usada no Odin Teatret, como "mobilização muscular e nervosa, ação precisa e retida, energia modelada, pronta para agir.”. Barba formula (2009, p 20-21, grifo do autor) o conceito de várias maneiras: “[...] impulso de uma ação que ainda se ignora e que pode tomar qualquer direção [...] O sats é a postura de base que se reencontra no esporte [...], quando se deve estar preparado para reagir.”; (2012, p. 91) “([...] 'preparação para a ação, para se lançar, para estar a ponto de...')". Ainda em Barba (2009, p. 71, grifo do autor),

Sats pode ser produzido com as palavras 'impulso', 'preparação', ou então 'estar pronto para...'. Na nossa linguagem de trabalho, indica [...] quando toda a energia já está aí, preparada para intervir, porém suspensa, ainda presa ao punho, borboletatigre pronta para alçar voo.".

E a mais poética (2010b, p. 266, grifo do autor): "Sats: as vibrações nervosas que escorrem na pele da gazela no instante que precede a fuga."

Para construir uma linguagem física e sonora o ator tem que pensar com o corpo todo. As tensões criadas a partir do domínio da fisicalidade são uma pista para o entendimento do domínio de energias exigido por um intérprete, que o levam ao corpo extra-cotidiano. $\mathrm{O}$ trabalho de modelar as energias é, para o ator, um procedimento técnico.

${ }^{127}$ Anotação pessoal. A Arte Secreta do Ator - Brasil, Brasília,10/12/2009. 
Pensar através de ações leva ao ajuste de qualidades gestuais direcionados ao invisível que será transmitido como um "vírus" para o público; diz Barba: "não é um trabalho de expressão e sim de precisão." Segundo ele, a ação torna-se crível pela precisão dos pés, das mãos e dos olhos. ${ }^{128}$ Varley salienta que como atriz, aprendeu a pensar com os pés e que o peso nunca deve estar distribuído igualmente sobre a base, com o risco de perder-se o impulso. Esse desenvolvimento do "pensamento pedestre" pode ser verificado na atenção à transferência de peso que todos os atores do Odin Teatret têm. Barba ressaltará a transformação de peso em energia, com exemplos físicos: deixar passar uma folha de papel sob os calcanhares, a tonicidade dos músculos da perna ao estar em pé, prestes a se deslocar (inclusive pedindo que toquemos em sua coxa para identificar as tensões musculares acionadas; a materialidade existe também na transmissão do conhecimento).

A ação está contida no tônus muscular do ator comprometido em mudar a percepção do espectador (BARBA, 2010b, p.159). Ela deve ser real e não necessariamente realista. Os atores aprendem a fazer ações reais no treinamento, com exercícios que os obrigam a estar no presente, aqui e agora. "A ação é como uma pérola, e os atores, pescadores. Quando se coloca o fio, coloca-se a estrutura.", compara Barba. ${ }^{129}$ Os exercícios criados a partir de ações juntam-se em uma sequência, criando a estrutura da partitura que pode ser modelada por meio de:

1. Ritmo: Lento/ rápido;

2. Qualidade de energia: leve/pesado

3. Tamanho: grande/pequeno;

4. Aspecto introvertido ou extrovertido ${ }^{130}$ : para "dentro" / para "fora";

5. Transposição para apenas uma parte do corpo: Ex. para as mãos, pés, coluna etc.;

6. Transposição de nível: Ex. várias formas de dormir, deitado; transpor para a posição sentada, transpor para em pé;

\footnotetext{
${ }^{128}$ Sobre o trabalho dos pés, encontramos considerações no capítulo 3 - Princípios que retornam, a partir da página 35, de A Canoa de Papel (2009); sobre a precisão das mãos e dos olhos, os apontamentos encontram-se no mesmo capítulo, nas páginas 51 e 52.

${ }^{129}$ Anotação pessoal. A Arte Secreta do Ator - Brasil, Brasília, 12/12/2009.

${ }^{130}$ Esses aspectos são detalhados na Tradição de Roberta Carreri, p. 139 deste trabalho.
} 
7. Encontrar a equivalência da partitura física com a voz ou com um objeto. Os itens 5 e 6 acima também são exemplos do princípio da equivalência.

8. Improvisações. As improvisações nascem das possibilidades baseadas nos procedimentos acima (ou outros que podem ser criados) que o ator escolhe para compor seus materiais. A capacidade de resgatar improvisações é uma das habilidades que o treino de "pensar com o corpo" deve proporcionar.

A partitura física, ${ }^{131}$ sublinha Barba, é como argila, que se adapta ao contexto. O que está abaixo do que se vê, são as subpartituras (2010b, p.64), “[...] é um elemento técnico que pertence à particular lógica criativa de cada ator", e revelam maneiras de viver a técnica pelos princípios que estão na base das diferentes formas expressivas, em diferentes tradições. A partitura por si só não é um resultado artístico. Explica Barba: "É como um pedaço de mármore ou argila, que deve ser esculpido. É uma parte do trabalho que deve ser feito a sangue frio, sem fetiches". ${ }^{132}$

Essas qualidades se relacionam aos princípios pré-expressivos, que consideram as ações em várias subdivisões. Esses princípios "permitem gerar a presença teatral, o corpo em vida do ator capaz de fazer perceptível àquilo que é invisível: a intenção.” (BARBA, 2009, p.22).

O pré-expressivo não implica em emoção nem afetividade, é um neutro que tem uma função clara, como as aeromoças, ao exemplificarem as saídas de emergência de um avião. E o extracotidiano pode ser comparado ao vestir, com organicidade, um vestido muito volumoso, que vai ser impregnado com as informações dinâmicas da forma de andar da modelo, com tensões escondidas, visando à naturalidade, no total domínio e aproveitamento do potencial máximo do farfalhar das camadas, no andar em uma passarela, por exemplo. ${ }^{133}$

\footnotetext{
${ }^{131}$ Sobre partituras físicas cf.: BARBA, 2009, p. 193-194; 200 -213 e 2010b, p. 60 -70. Ver também p. 169 deste trabalho.

${ }^{132}$ Anotação pessoal. A Arte Secreta do Ator - Brasil, Brasília, 12/12/2010.

${ }^{133}$ Idem, 10/12/2009.
} 
Durante a montagem da partitura, uma proposta é de se trabalhar como na edição de um filme; cortar, ir para frente e para trás, acelerar, saltar de uma imagem à outra (BARBA, 2009, p.200). Barba aplicou essa possibilidade em 2011, seguindo a seguinte sequência: ${ }^{134}$

1- Atores ensaiam suas cenas sentados em uma cadeira, mantendo as mesmas qualidades, mas sem os deslocamentos do andar.

Primeiramente, as cenas de apresentação dos atores do curso foram realizadas simultaneamente, com todos sentados, sem texto, somente com os sinais dinâmicos, os impulsos da ação, "como quem passa uma coreografia na coxia antes de bailar."

2- Ensinar a partitura a um colega imaginário. Ao pedir para ensinar, nota-se que está procurando do ator a consciência do trajeto de cada ação bem como seu início e final. A exatidão do lugar ocupado no espaço pelo movimento em sua mais detalhada precisão. Segundo ele, quem ensina, observa se a posição está correta, controla mais a ação do que se preocupa consigo, e pode aprender a "dicção" de cada ação no nível físico, estabelecendo, no encadeamento, uma narrativa.

3- Criar a narração como um filme: ao montar a película, estudar os fragmentos; considerar as várias possibilidades de montagem de cada trecho. Ao mesmo tempo, ser o montador e o próprio filme. Pensar em "categorias de edição": ir mais rápido, mais devagar, dar rewind, close etc.

4- Montar um filme em “3D”, acrescentando efeitos em terceira dimensão, ou seja, levantar-se, realizar o movimento original, e voltar a se sentar.

5- Incluir um hiccup, ${ }^{135}$ i.e, um "soluço", como um "defeito" na linearidade da montagem.

6- Trabalhar a cena dividindo-a quadro-a-quadro.

7- Fazer um clip do filme, com dez quadros no máximo. O clip traduz-se como uma seleção de imagens que fornece uma sugestão do trabalho todo; não é uma montagem linear.

\footnotetext{
${ }^{134}$ Toda a sequência abaixo diz respeito a anotações pessoais do dia 08/12/2011, A Arte Secreta do Ator - Brasil, Brasília.

${ }^{135}$ Este é um recurso que visa quebrar a constância rítmica, mudando a percepção do espectador.
} 
O ator deve perguntar-se quais são os quadros interessantes a serem incluídos para se oferecer esse panorama.

8- Acrescentar contrastes "dramáticos": como uma ação rápida, uma lenta; criar quadros constituídos de pares opostos complementares: alto/baixo; introvertido/extrovertido etc.

8- Como ator, pensar ainda em mais dois pontos de vista diferentes, o do montador e do diretor, estabelecendo cortes em pontos do quadro e sua junção com outra parte.

9- Em duplas, montar o filme com vinte quadros, utilizando o clip de cada um, sem pausas. Durante a montagem, trabalhar sobre o ritmo. Na dupla, evidenciar os contrapontos (quando um está rápido o outro faz lento) ou as concordâncias (os dois rápidos, p. ex.).

Barba salienta, a essa altura do exercício, que o ritmo é a alma do que o espectador está percebendo. Como o ator modela as qualidades é também o que prende o espectador. $\mathrm{O}$ ator deve se lembrar daquilo que, como espectador, o leva a outro estado de experiência. "Não se trata de atuar, mas de criar consciência do ritmo do próprio quadro."

10- Barba propõe então um "filme" com todos os clips. Todos são "Vênus de Milo",136, ou seja, devem realizar as ações sem utilizar movimentos com os braços, mantendo só o impulso interno e tomando cuidado para definir momentos em que eles são necessários, como na sustentação do corpo.

11- Acrescenta uma tarefa: em algum momento uma carta deve ser entregue ao seu amante. Barba comenta que quanto mais o contexto narrativo é conhecido, mais devemos escondê-lo, i.e, na tarefa, se sabemos que são amantes, temos que esconder isso, criando subpartituras pessoais (ex. são apaixonados, mas ainda não o sabem, o marido está presente etc.). Realizar o trabalho do ator baseado em uma maneira paradoxal de pensar e buscar como os processos mentais podem se transformar em ações físicas.

O resultado do exercício revelou qualidades de movimento, ritmos e intenções surpreendentes para os observadores e atores, ao perceberem, no diálogo com o par, as novas

\footnotetext{
${ }^{136}$ Em referência à famosa escultura grega clássica, pertencente ao acervo do museu do Louvre, em Paris. Se olharmos para as costas da escultura, percebemos claramente as tensões musculares percorrendo sua coluna vertebral, apesar de ser feita de mármore. E seu abdômen contraído também reflete o "esforço" muscular, necessário para a postura em espiral, remetendo à atitude dos braços inexistentes. Fotos disponíveis em: <http://www.louvre.fr/en/oeuvre-notices/aphrodite-known-venus-de-milo>. Acesso em: 14/02/2013.
} 
narrativas corporais que surgiram das relações. Barba formula: “O que significa improvisação dentro de uma estrutura fechada como a de uma peça? Ser colaborativo em cena, olhar e escutar o outro, de forma a permitir um diálogo em que cada um manifeste seu temperamento.".

O diretor faz mais considerações sobre o exercício, e explica que o ator deve sempre lutar contra a ênfase no movimento e de querer mostrar que se está fazendo algo interessante; o ator deve realizar a tarefa. Lutar contra clichês dinâmicos, portanto, contra a identidade rítmica. Diz que o clichê não é um problema, mas sim a maneira que o utilizamos e a quantidade de clichês que conhecemos. Além disso, o ator tem que ter a capacidade de inventar, como Shakespeare, que inventou mais de mil palavras para a língua inglesa. Estar muito consciente quando se pensa por meio de ações, pois, depois de algum tempo, seu próprio clichê dinâmico passa a ser um filtro que se torna reconhecível e repetitivo para o espectador. O que dá a sensação de que o corpo pensa, é a diferença de ritmos, e a segmentação da ação é que possibilita ao ator o reconhecimento para poder trabalhar as mudanças de ritmo, daí a necessidade de ser ter noção do começo e fim de cada ação, sendo que a segmentação é diferente da fragmentação; a primeira está interligada à ação e a segunda implica em perda de conexão entre as ações. (BARBA \& SAVARESE, 2012, p. 192)

Mas como inventar? Criar na repetição que, ao invés de nos levar a uma ação original, pode estabelecer uma moldura fixa e mecânica? Cabe ao ator, através do ritmo e outros recursos, como a subpartitura ${ }^{137}$ interna, dar a justificativa e ressignificação para suas ações, sem mudar ou acrescentar. Modelar o como justificar a incompreensão aparente das ações com a sensatez da compreensão para as descobertas intrínsecas entre ação e sentido. A repetição deve servir para reencontrar a ação original depois de todo o processo de ensaios, estreia, apresentações, cuidando para que não incorra no "piloto automático" de sua execução. Diz Barba: "Muitos conhecem os truques da atuação, mas como manter o coração vivo, pulsando, porém escondido?". E esta é uma resposta que cada ator tem que encontrar para si mesmo.

Os procedimentos compõem camadas, que vão se sobrepondo em exigências estéticas de organicidade e geração de entendimento, ou seja, sentido e reconhecimento de signos pela plateia. Barba cita os perigos do óbvio, do bizarro ou do "culto" às ações físicas; a

\footnotetext{
${ }^{137}$ No capítulo III trataremos especificamente do termo. Ver p. 169.
} 
comodidade que esses procedimentos geram, como se apenas juntar uma sequência de ações fosse o suficiente para trazer presença e sentido ao que se está fazendo. Deve-se lutar contra a inércia, que tende ao mais fácil ou ao mais estranho. A partitura física tem que ser humanamente reconhecível, apesar da estilização. Tem que haver a produção de associação, reconhecimento, em um processo "ideoplástico"138, no qual a ideia torne-se visível pelo movimento ${ }^{139}$.

E como dar consistência à ação? Busca-se reconstruir a normalidade usando um montante de energia que deve influir sobre o espectador. $O$ ator está sempre fazendo muscularmente o oposto do que é mostrado, para trabalhar as oposições e quebrar os automatismos. Destaca os princípios de complementariedade e oposição para dilatar o corpo do ator e criar presença. Ainda, esconder e mostrar, segmentar ações, descobrir o valor do peso e sua transferência para transformá-lo em energia que realiza uma ação, criando sinais polissêmicos, imagens esculpidas, para que a partitura se module à disposição física do espaço e também à visão do espectador. $O$ ator deve transformar o seu pensamento imediatamente em ações, que derivam de uma lógica motora, rítmica conquistadas através do treinamento. Permitir que o diálogo interior manifeste-se através de ações.

A compreensão de onde começa e termina uma ação ajuda a identificar os impulsos e possibilita a escolha de mudanças de direções da ação seguinte, por exemplo. A segmentação consciente das ações físicas serve para compor a sequência de movimentos em um mundo no qual o ator é, ele mesmo, "a realidade, o microscópio e seu próprio observador." 140 Ator deve desenvolver a capacidade de se observar, não se deixar levar pela cachoeira de sensações. ${ }^{141}$

\footnotetext{
${ }^{138}$ Grotowski (2011, p. 30) usará esse termo em uma entrevista concedida à Barba em 1964, intitulada "O novo testamento do teatro", para referir-se à realização do ator no ato de doar-se em cena. E achamos no site do Odin Teatret uma conceituação sobre processos ideoplásticos, sendo "a capacidade de transformar pensamentos e sentimentos em ações e reações disciplinadas". Tradução nossa. Original: "the capacity to transform thoughts and feelings into disciplined actions and reactions". Disponível em: 〈http://www.odinteatret.dk/events.aspx>. Acesso em em: 27/06/2014.

${ }^{139}$ Série de anotações pessoais A Arte Secreta do Ator - Brasil, Brasília, 09/12/2011.

${ }^{140}$ Idem. 10/12/2009.

${ }^{141}$ Lembramo-nos do seguinte trecho de Grotowski (1993, p. 78): “O Eu-Eu não que dizer estar dividido em dois, mas ser duplo. Trata-se de ser passivo na ação e ativo na observação (ao contrário do habitual). Passivo quer dizer ser receptivo. Ativo, estar presente. Para nutrir a vida do Eu-Eu, o Performer deve desenvolver, não um organismo-massa, de músculos, atlético, mas um organismo-canal através do qual as energias circulam." Tradução nossa. Original "El Yo-yo no quiere decir estar cortado em dos sino doble. Se trata de ser passivo em la acción y activo em la mirada (al contrario de lo habitual). Passivo quiere decir ser receptivo. Activo estar presente. Para nutrir la vida del Yo-Yo, el Performer debe desarrolhar no um organismo-masa, organismo de músculos, atlético, sino um organismo-canal a través del cual las fuerzas circulam.” (grifo do autor).
} 
As micropausas devem servir, também, para quebrar a expectativa do espectador. O encadeamento e reconhecimento das ações no sentido cinestésico, ou seja, do posicionamento corporal, permite orientar o espectador sobre o que se passa, estabelecendo categorias de informação para o mesmo. Produzir uma reconstrução da arquitetura da vida, com suas tensões, fazendo com que isso literalmente "mexa" com o espectador.

Pode-se pensar por oposições, complementaridades, realizar as ações negando-as, não chegar rapidamente ao seu objetivo, mas empreender um grande percurso para se chegar à ideia. Perceber que o impulso vai para a direção oposta de onde o ator realmente se dirige. A ação não pode ser binária, deve ser construída de forma ternária, pois sempre contém o contra-impulso.

Os princípios serão retomados e trabalhados a cada exercício aplicado ao longo do workshop. Chegar ao "corpo que pensa" exige a prática sistemática e consciente das ações que comporão a partitura do ator.

\subsubsection{O diretor e os atores}

Nesse espaço de convivência e trabalho foi possível experimentar e testemunhar a relação diretor-atores com jovens e experientes artistas, incluindo diretores e pesquisadores, que muitas vezes colocavam seus entendimentos sobre a técnica lida em livros frente a frente com o mestre. Também a direção sobre Ave Maria, ${ }^{142}$ com Julia Varley, atriz há 37 anos no Odin Teatret e que acompanha o diretor em seminários. Presenciamos a execução concreta da atriz às ordens e sugestões do diretor e testemunhamos, no corpo de Varley, o entendimento e resposta imediata aos princípios, cada vez que Barba pedia que exemplificasse algo. Varley é uma figura silenciosa, observadora, com uma risada deliciosa. Ao lado do diretor, às vezes discorda claramente de algo que ele fala, ao que Barba, percebendo, passa-lhe a palavra imediatamente, para que faça suas considerações. Em Pedras D'agua, Varley (2010, p. 219) remete essa reação, "de balançar a cabeça", principalmente à aparência que as conclusões sobre a técnica podem tomar ao serem explicitadas claramente, como se fossem pressupostos para alcançarem os resultados e não processos que se deram pela prática. Do alto de sua experiência é a atriz que atende ao diretor, realizando tarefas para nos demonstrar, com a

\footnotetext{
${ }^{142}$ Peça ensaiada entre os anos de 2010 e 2011 na presença dos participantes de A Arte Secreta do ator - Brasil.
} 
clareza do saber incorporado, algum princípio específico ou realizando improvisações sobre temas que Barba cria. Julia Varley (2010, p. 195 a 199) conta-nos sobre isso também em seu livro, quando fala da relação da atriz com o diretor. No programa de Ave Maria (2013, p. 20), Varley comenta sobre o processo específico dessa montagem. Cita a improvisação com uma cadeira que Barba a pediu para fazer na edição de 2009 e o trabalho sobre o material, desembocando no seu uso cênico, cheio de reduções e ressignificações. Acompanhei a criação e transformação dessa partitura, bem como o processo de montagem de Ave Maria, que Varley (2013, p. 23) narra ter sido um dos mais espinhosos de sua carreira nos últimos tempos. Houve muitos confrontos entre atriz e diretor, impasses e o processo extenuante que foi trabalhar em público com a criação e fixação de improvisações que, em situações de ensaios normais, levariam muito mais tempo para serem assimiladas (VARLEY, 2013, p.2122). Mas para os participantes, compartilhar da intimidade do ensaio de um diretor com sua atriz, gerou aprendizado e ainda maior respeito pelo rigor com que o trabalho é feito. As várias das sugestões que dávamos eram testadas por Barba, com algumas efetivamente aproveitadas na montagem, como constatamos ao assistir à peça finalizada em 2012.

Esse espetáculo foi feito por Varley em homenagem à atriz chilena María Cánepa ${ }^{143}$ (1921-2006). Éramos convidados a assistir aos ensaios e dar sugestões sobre questões que Barba nos colocava, dizendo que não sabia como resolvê-las. Esse espetáculo têm grandes desafios técnicos a meu ver. Varley atua com o rosto coberto o tempo todo. O trabalho se inicia com Mr. Peanut ${ }^{144}$, que se transforma também em Miss, vestindo-se de mulher, como uma dona-de-casa, e noiva. As trocas de roupa são feitas em cena, perfeitamente coreografadas. Os objetos manipulados exigem grande habilidade da atriz, pois seu campo de visão é restrito. Em 2011, havia uma cena em que ela, riscando um fósforo oculto em sua luva, colocava fogo em um jornal posicionado no chão e à frente do elemento central, uma

${ }^{143}$ O espetáculo evoca o encontro e a amizade de María Cánepa e Julia Varley. São impressões, vivências e momentos ao lado da atriz chilena que recebeu o grupo em seu país, pela primeira vez, em uma época de ditadura ferrenha. No programa de Ave Maria (Holstebro, junho de 2013. Trad. Marilyn Antunes), Varley (p. 7) conta sobre esse encontro e o que a comoveu em María: "Eu conheci María Cánepa durante uma turnê do Odin Teatret no Chile, em 1988, no tempo da ditadura do general Pinochet. [...] Eu fiquei no centro de Santiago, no apartamento de Maria e de seu jovem marido, o diretor Juan Cuevas. [...] Eles cuidaram de mim.”; (p. 12) "Eu sempre admirei em María a combinação de ingenuidade e astúcia, doçura e decisão. Em particular me comoveu a entonação, o ritmo e o calor da sua voz que expressa essas características. Ela tinha na voz a segurança de uma atriz que acreditava no valor do teatro."

\footnotetext{
${ }^{144}$ Personagem arquetípico do Odin Teatret, Mr. Peanut acompanha os espetáculos de rua do grupo desde 1976. É construído com a cabeça de uma caveira sobre meio tronco que se encaixa sobre os ombros da atriz, aumentando sua altura. Herdado por Varley (2010, p. 157) de um ator antecessor, é merecedor de grande apreço pela atriz. A certa altura do ensaio, Barba comenta: "Se cair o avião, eu posso morrer, contanto que Peanut seja salvo". Anotação pessoal, A Arte Secreta do Ator - Brasil, 2011.
} 
tábua de passar roupas. Lembro-me da sensação de angústia que senti quando a atriz teve dificuldades com a tarefa, enquanto me contorcia na cadeira, torcendo para que o fósforo acendesse e ela pudesse continuar com a progressão das ações. ${ }^{145}$

Observamos a dinâmica de um duelo entre diretor e atriz, durante os ensaios de Ave Maria, no ano de 2011, quando Barba queria que acontecesse "uma tempestade em cena, que destruísse tudo". Estava insatisfeito com o ritmo da peça e queria que tudo fosse revirado, enquanto Varley, paciente, mas firmemente, explicava que havia elementos de cena frágeis que, se quebrassem, seriam insubstituíveis, como um pequeno caixão de madeira, feito sob medida. Inicialmente, sem contar ainda suas ideias, Barba pediu a Varley que improvisasse sobre um tema e imagens que ele iria passar. A atriz, então, improvisou longamente sobre "uma tempestade de grande fúria, que causa furacões e parte árvores"; "um pônei enfurecido que quer atacar outro pônei com mordidas"; "uma luta entre cavalos árabes enfurecidos"; "uma mulher e um fantasma, que violenta a mulher"; "a fase final entre dois gladiadores, em que um estrangula o outro, enquanto o estrangulado luta violentamente pela sua vida"; "São Sebastião recebendo sete flechas, de diferentes maneiras". ${ }^{146}$

Após as improvisações, Barba anuncia a segunda tarefa: a tempestade destrói tudo em cena. Apresento agora o relato literal das anotações informais do meu diário sobre o que se seguiu: "Impasse entre o diretor e a atriz. Atriz hesita em derrubar os elementos, pois não tem como substituí-los. Eugenio insiste, procura meios de 'quebrar' as bases de apoio da tábua de passar roupas sem rompê-las. Desfaz o varal que está em cena, joga as coisas no chão; tenta se enforcar com a corda do varal. Pede que Julia vista o Mr. Peanut e o enforque com a corda, de forma que a cabeça/corpo do boneco saia com a corda e fique pendurado, liberando a atriz. Impasse técnico: como fazer dar certo? Acham uma forma: Julia dá duas voltas com a corda no pescoço do esqueleto e vai abaixando, até ele se soltar do seu corpo... Depois Julia deve soltá-lo e o colocar deitado, à frente da tábua de passar. Eugenio pede que teste formas diferentes de trazer o esqueleto. Eugenio desconstrói todo o cenário; volta algumas coisas no lugar. Pede que Julia faça o enforcamento pelo outro lado. Falam em italiano o tempo todo.

\footnotetext{
${ }^{145}$ Em 2012, quando assisti à peça, perguntei para Julia Varley o que tinha acontecido com a cena do fósforo, não mais presente na versão final. Contou-me que em um ensaio quase puseram fogo no teatro e assim a cena foi excluída. Respirei aliviada.

${ }^{146}$ Os temas das improvisações não têm "nunca relação direta com as cenas do espetáculo [...]" ensaiado, aponta Carreri (2011, p. 116). Varley (2010, p. 221) ressalta que Barba faz isso para afastar as tendências à ilustração, redundância e imposição de uma só visão. Sobre isso, Barba (2010b, p. 224) comenta: "Se não coloco o ator em dificuldade, é difícil que depois ele também consiga me colocar em dificuldade, surpreendendo-me."
} 
Pede que repita a cena, solicita improvisações, testa músicas. ${ }^{~ 147}$ Os impasses desenrolavamse diante de nossos olhos ávidos por ajudar nas soluções e perplexos por compartilhar aqueles momentos de intimidade de dois "monstros sagrados" na confecção de uma obra, comuns, no entanto em um ambiente de ensaio. Ao final de uma discussão acalorada entre eles, Barba, a certo momento falou: "O que vocês estão testemunhando é o trabalho de uma atriz tentando preservar as coisas que lhe são caras". Barba, então, explica que precisa de um momento de terror na peça; um momento em que os espectadores têm que ter medo. E divide a constatação sobre o olhar "esquizofrênico" do diretor: ao mesmo tempo técnico e sobre o que vai "afetar" o espectador. A ele interessa, segundo suas palavras, a capacidade do ator entusiasmar-se, mesmo na repetição. Como diretor, visa garantir o rigor sobre o que o ator vai apresentar ao espectador. Compara-se a uma parteira, que tem que ter certa brutalidade ao cortar as ações, para proteger o ator no seu nascimento em cena. Interessa-lhe montar soluções que levem o espectador a outro estado de consciência; reconhecer as "fraturas do espetáculo" e cuidar pra muni-lo também de uma continuidade, achar sua fluidez. ${ }^{148}$ Como seus mestres, trabalha sobre o específico (e não em geral) e procura a justa medida, aquilo que é necessário.

Segundo Varley, ao lidar com as intervenções do diretor, há a mão implacável que corta, às vezes machuca, e também acaricia, mas sempre respeita as constatações, os impulsos do seu corpo de atriz, que detém as ações. Em seu livro (2010, p. 221-222), relata como uma eventual frustração, causada pelo fato de muitas vezes ter seu trabalho todo modificado, traduz-se em plena confiança sobre o olhar do diretor. E também como alcançou uma noção de independência, ao criar a partir de si mesma, concentrando-se no seu trabalho de atriz.

Barba (2006, p. 97) descreve o trabalho de Grotowski em seminários realizados nos primórdios do Odin Teatret, já em Holstebro, da seguinte forma:

Às vezes Grotóvski trabalhava com um único participante diante da presença de
todos, Por mais de uma hora, éramos testemunhas de como o estimulava com
imagens [...]. Eram momentos excepcionais, e o que comovia era a delicadeza e a
proteção com que Grotóvski era capaz de acompanhar o ator, que se entregava
completamente em suas mãos.

Essa é também uma boa descrição para o que testemunhamos nos cursos com Barba. Há uma infinita paciência em se trabalhar os detalhes, questionamentos potentes, imagens instigadoras das quais se utiliza para incentivar o ator a dinamizar suas ações e significa-las

\footnotetext{
${ }^{147}$ Anotações pessoais. A Arte Secreta do Ator - Brasil, Brasília, 12/12/2011.

${ }^{148}$ Anotação pessoal. A Arte Secreta do Ator - Brasil, Brasília, 11/12/2009.
} 
exteriormente. Explorando seus procedimentos como diretor com os atores dos cursos, o trabalho de Barba acontece com cenas que ele escolhe, após assistir a todas, nas quais exemplifica como o ator pode cortar excessos, encontrar os impulsos e ressignificar as ações. É um trabalho muitas vezes "manual", em que "esculpe" paciente e obsessivamente o ator, no esforço de fazê-lo entender onde é possível chegar com suas ações. Rasmussen, no texto As Mudas do passado, traça um panorama dessa ação de ambos os diretores:

\begin{abstract}
Sempre se fala de treinamento, de seminário, de transmissão das técnicas e do saber teatral, e é como não se visse o que tem por traz de tudo isto: dar vida. Para alguns, ou para muitos, talvez seja só um problema de técnica, de profissionalismo do professor com o aluno. Mas quem viu Grotowski ou Eugenio trabalhar com um aluno, experimentou algo diferente. De cara parece que eles esquecem tudo o que está à volta, pensam em outra coisa. É como se não tivessem nenhum método e não tivessem nada para si. Falam, explicam, ordenam, tocam, riem, jogam, imitam, começam a improvisar com as palavras e com as imagens, repreendem, se assombram, ora são cálidos ora gélidos, ora cortantes e ora prontos para proteger. Aqueles momentos constituem algumas das raras ocasiões em que as palavras como "total confiança", "abertura", "honestidade no trabalho", não têm nada de excessivo. Então você pode ver e parece um milagre - como algo começa a viver no corpo, na voz do aluno. ${ }^{149}$
\end{abstract}

Como diretor, quer sempre lutar contra a obviedade no resultado em cena. No caso dos cursos no Brasil, com corpos latinos e sul-americanos, comentários específicos de Barba e Varley dizem respeito principalmente à ênfase e expressividade dos atores em cena, notadas como uma tendência "caliente" ao exagero e à extroversão. Claramente, não se trata de crítica ao modo de ser dos nativos deste hemisfério, mas sim uma ressalva a tendências que precisam ser conscientes, para que não se tornem clichês e ilusões de expressividade. Aqui se salientam os aspectos da "inculturação", termo adotado por Barba para exemplificar o "processo de passiva impregnação sensório-motora de comportamentos próprios de uma cultura" (BARBA \& SAVARESE, 2012, p. 228). Isso evidencia que, apesar de utilizarmo-nos de técnicas que levariam à "aculturação", ou seja, recursos que artificializam o comportamento (como as partituras corporais e vocais, p. ex.), os aspectos inculturados muitas vezes se sobressaem. Isto não é um problema em si, desde que seja percebido e não uma manifestação inconsciente de um automatismo. Barba salienta que o caminho da inculturação, utilizado no campo teatral, também é uma metodologia que ativa os níveis pré-expressivos. (2012, p. 229). O que estamos enfatizando aqui é a necessidade do ator conhecer e lidar com suas tendências de comportamento passíveis de serem ou não uma escolha no que ele apresenta em cena.

${ }^{149}$ Publicado pela primeira vez na revista Scena, 1979. Também disponível em italiano no livro Il cavalo ciecco (2006, p. 171). A tradução usada aqui é de Suzi Frankl Sperber (1999, p. 17), para a Revista do Lume. 
Uma das observações recorrentes nos quatro anos, com diferentes pessoas foi sobre a utilização das mãos, dos braços $^{150}$ e do rosto. Salienta que o excesso de movimentos dessas áreas do corpo dilui a atenção do espectador e cria, perigosamente no ator, a sensação de que está se expressando. Varley sempre ressalta que liberar a voz nos exercícios vocais ou na cena, é, muitas vezes, confundido com caretas, na crença de que a voz se projetará dessa forma. E pontua as respirações exageradas, os olhos perdidos, o excesso de força física e vocal, bem como os movimentos que chegam à sua extensão máxima, pois, assim, perdem a capacidade de irradiar vida, tornando-se estrangulados. ${ }^{151}$ Para eles, interessa o comprometimento com a coluna vertebral, as informações dinâmicas presentes nessa área central que independem de gestos formais, mas que trazem vida à forma. É para exercitar essa possibilidade, Barba pede que os atores sejam "Vênus de Milo"152 e realizem suas partituras sem utilizar os braços, por exemplo, para que entendam que a informação não está nas articulações de braços e mãos, mas sim no torso, ao longo da espinha dorsal.

Em 2011, Barba fez as seguintes considerações, após a apresentação do "cartão de visita" dos atores:

O que passa na minha cabeça quando vejo o trabalho de vocês? Às vezes me pergunto por que estão fazendo isso. Às vezes não entendo nada, mas fíco persuadido. Porque alguns me persuadem? Quando se entra em um território diferente da lucidez, que faz o espectador alucinar. Acreditar que o ator deve fazer o espectador ler seu próprio mundo emotivo, suas próprias referências. $\mathrm{O}$ ator não deve se autocensurar, mas deve conhecer e lutar contra suas próprias ênfases e clichês de ritmo durante o treinamento. Reconhecer várias possibilidades de movimento ou que já fizemos ou que já vimos. Tonicidades corporais que o espectador reconhece com acolhimento ou rejeição. Ao pensar com ações, não utilizar a construção de palavras do pensamento, mas usar palavras de carne. Quando a atenção do diretor se desperta? Quando o monólogo do ator desperta nele o seu próprio monólogo de referências. Remete a um pertencimento à experiência sinestésica, tornando a consciência do corpo como um sexto sentido. ${ }^{153}$

\footnotetext{
${ }^{150}$ Diz Barba, durante o curso: "Os braços são nosso Iago", em referência ao personagem de Shakespeare, que traiu Otelo. Anotação pessoal. A Arte Secreta do Ator - Brasil, Brasília, 2012.

${ }^{151}$ Esse é um princípio que pode ser notado em várias abordagens corporais, nas quais as articulações devem "respirar", ter espaço entre elas, para que propiciem o próximo movimento. A Prof. ${ }^{a}$ Dr. ${ }^{a}$ Sayonara Pereira sempre pontua essa condição em suas aulas práticas na ECA-USP, baseadas nas influências da dança moderna somada às noções instauradas pela geração alemã dedicada à dança teatral.

${ }^{152}$ Como descrito na p. 73 deste trabalho.

${ }^{153}$ Anotação pessoal. A Arte secreta do ator-Brasil, Brasília, 08/12/2011.
} 


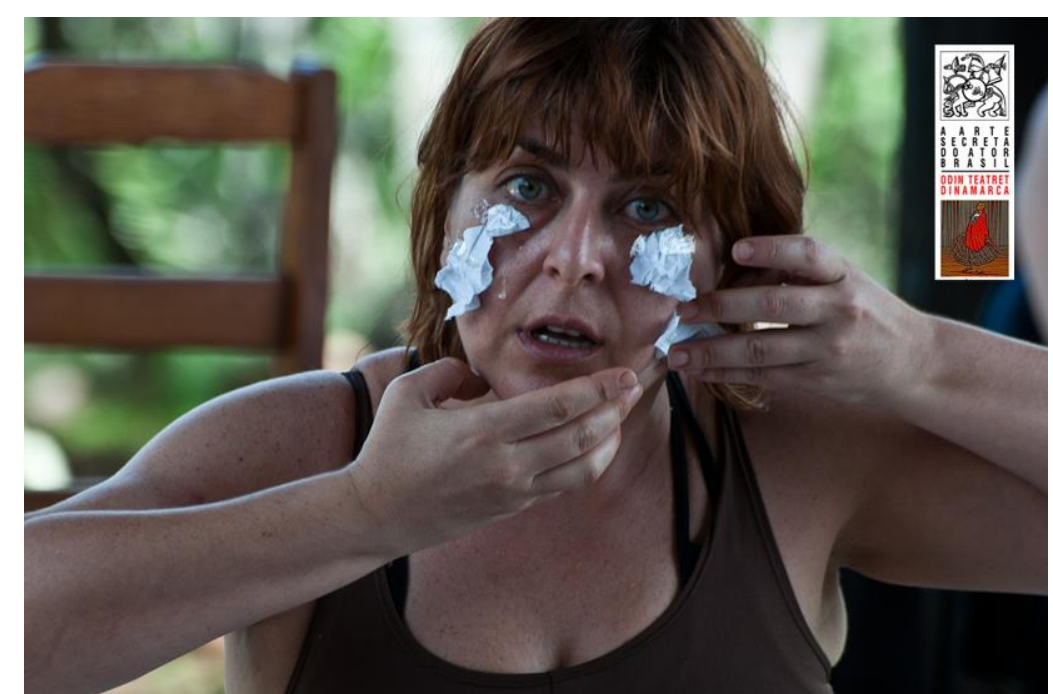

Figura 15. Apresentação do "cartão de visita". Tema: A flor das idades. A Arte Secreta do Ator - Brasil, 2010. Foto: Edu Barroso.

O ator deve fazer um trabalho secreto, que é muscular a fim de criar uma empatia de tonicidades, um feixe de tensões. Não manter o mesmo ritmo ou deixar que o espectador saiba o que vai acontecer. Uma recorrência ao se adotar as partituras é a redundância de ações físicas meramente ilustrativas, sem a participação da coluna, e um exagero de gestos que se tornam monótonos. Varley evidencia que a unidade de direção espacial, sempre para frente ou para um só lado, rouba a tensão possível na direção oposta. Também ressalta que o ator deve perceber para onde se direciona espacialmente a forma que está sendo executada no encadeamento das ações nas partituras. A atenção não deve estar voltada para dentro nem para o que se está fazendo, mas sim para o que o ator está criando fora de si, lançando as imagens com os olhos e com o corpo. ${ }^{154}$

Barba proclama que o ator deve ser o embaixador da vida, mostrar o dia e noite, realizar simultaneidades e expressar estratégias bem organizadas na ação. O diretor deve manipulá-las para transmitir energia ao espectador e pode mudar a ação original externamente, mas sem que o ator perca sua ação dinâmica, pois a forma exterior por si só não é interessante, mas sim a informação dinâmica interior. Para que o diretor possa trabalhar sobre o que o ator traz de "interioridade", a partitura física serve de campo comum permitindo que se encontrem. ${ }^{155}$

\footnotetext{
${ }^{154}$ Série de anotações pessoais. A Arte Secreta do Ator - Brasil, Brasília, 2010.

${ }^{155}$ Anotação pessoal. A Arte Secreta do Ator - Brasil, Brasília,12/12/2010.
} 


\subsubsection{Trabalho com o texto ${ }^{156}$}

O texto é tomado como um dos elementos que compõem o espetáculo. Há uma diferenciação nessa abordagem, pois o espetáculo não é conformado para o texto e sim, com o texto. Dessa forma, o texto não tem um papel de supremacia na composição dos materiais do ator, apesar de ser possível partir de um texto para trabalhar as ações físicas, este não foi o procedimento recorrente no trabalho do grupo, sendo geralmente o último elemento a ser colocado.

Durante os cursos, recomendam que as improvisações sejam feitas com textos diferentes do que será usado no palco. Isso para evitar a tendência de ilustração, que achata a possibilidade de criar uma experiência além da obviedade. Porém, ao colocar o texto final nas partituras, "usá-las como uma faca para abri-lo" e descobrir nas ações o que pode iluminar o texto. Dessa forma, as ações físicas e vocais são tomadas como instrumento de relação com o texto e a descoberta das relações possíveis entre eles (texto e ações) abrange as qualidades descobertas também na forma de o falar, sem partir da significação.

E como o "esqueleto dinâmico" das ações, ou seja, partituras físicas e vocais, pode se relacionar com a dinâmica do texto? No processo de justaposição do texto sobre as partituras, a narração e sua significação, ficam momentaneamente à parte. Ao se trabalhar sobre as ações com o texto, ainda sem "querer dizer" alguma coisa, possibilitamos o surgimento da escuta do que, entre as ações vocais e físicas e o texto, possa nascer. Criar uma nova forma de narração na relação entre os níveis físicos (corpo-voz) e da fala através de ritmos e ações. Achar e limpar redundâncias, ilustrações, excessos e, ao mesmo tempo, estar atento aos momentos de simultaneidade, criação de sentidos e justificação pertinente entre o texto e as ações, que podem "acender" o que está sendo feito e dito.

Varley ressalta que é importante que haja sincronia da fala com as ações, sendo que isso não quer dizer que a dinâmica da fala tenha que ser a das ações. O que devemos achar são momentos de coerência nos impulsos. Deve-se tomar cuidado para não marcar o começo ou o final da fala e trabalhar sobre as transições, conectadas ao impulso, também na voz. Varley chama a atenção sobre perigos de uma musicalidade igual o tempo todo e de achar que a boca é que faz a variação, ao invés da voz.

\footnotetext{
${ }^{156}$ Referente a anotações pessoais nas oficinas A Arte Secreta do Ator - Brasil, Brasília, em 2010, 2011 e 2012, principalmente.
} 
Barba dirá que não é um problema de conteúdo, mas sim de informação. Sobre isso entendemos que o que o texto diz ou quer dizer, está submetido à forma como o dizemos e às relações que estabelecemos com a partitura física, significando o texto em uma conversa com o interior (imagens, impulsos, compreensões pessoais sobre o conteúdo) e sua exterioridade manifesta nas ações. "A dramaturgia dinâmica e orgânica do ator tem a ver com esse monólogo interior que é incompreensível, mas tem que se ligar e dar sentido ao texto.”, pontua Barba. A interpretação do texto deve ser a consequência de um processo de construção consciente das relações entre voz e corpo, nas quais as intenções vão sendo descobertas e não são condições a priori. Algumas estratégias recomendadas por eles são: para aprender o texto, ler em voz alta e marcar as respirações naturais que acontecem, sem respeitar pontos e vírgulas. A onda respiratória deve ser estudada de forma a colocar pausas em momentos que enganem a expectativa da audiência. $\mathrm{O}$ cuidado com as pausas deve ser redobrado, pois criam previsibilidade para o espectador. Elas devem ser transições ativas e não algo que estagna o texto. E falar "sem pausa" não que dizer mais rápido, assim como falar alto ou baixo não significa acelerar ou ralentar o texto. Estabelecer um grau zero da fala, sem intenções prévias, para criar a ação vocal. Sincronizar o texto nas ações e não vice-versa, permitindo que o corpo participe, pois o impulso da ação física é que vai repercutir na voz, criando possibilidades de entonação. Impregnar a palavra com o ritmo da ação, como em um salto, por exemplo. Para exemplificar, muitas vezes trabalharam jogando um objeto, como um chinelo, uma mochila ou garrafa d'água, com um ator enquanto este falava continuamente seu texto, pedindo que, ao lançar e pegar o objeto ou nos deslocamentos pelo espaço, o ator permitisse que as variações corporais afetassem o modo de falar o texto. Dessa forma, procuram desconectar o ator da "interpretação" do texto. Fazem uso de imagens, também, como "a voz é um sol irradia seus raios pela boca", pintar com a voz "como Michelangelo na Capela Sistina", a voz como "águas escuras correndo na noite". Abraçar com a voz, irradiando-a do centro para as laterais do ambiente. Em suas anotações pessoais, publicadas em Queimar a casa (2010b, p. 273), Barba reflete:

Num espetáculo, a verdade do que está sendo narrado não depende da fidelidade a um texto preexistente, mas do poder de persuasão do ator. Somente o ator pode converter palavras escritas, pensamentos e fantasias em ritmos, tensões e musicalidade: (sic) em carne que seduz a mente e faz com que se veja através.

Segundo ele, o ator deve saber que é um contador de histórias, capaz de falar todas as línguas. 


\subsubsection{Objetos parceiros}

Em 2010, após assistirmos a um vídeo com o treinamento dos atores do Odin Teatret $^{157}$, Barba conta que no início era importante criar ações que obrigasse o outro a reagir. Para isso trabalharam com bastões, em exercícios de ataque e fuga. O bastão é um companheiro que compele o ator a reagir com todo o corpo. Criaram critérios para estabelecer a obrigação de reagir: nunca pegar pelo meio, manter afastado do corpo, manter em postura de sats - ataque.

Os exercícios com bastão visam tornar reconhecíveis esses impulsos físicos gerados pela manipulação e peso do objeto. Primeiramente os atores trabalham em duplas, com um bastão entre eles, criando um conjunto de ações e reações cujo objetivo é mudar as tendências e o comportamento físico da outra pessoa. O bastão exerce o papel também de aprimorar a escuta aos movimentos do outro, tirando a atenção de si e atentando para as indicações dinâmicas executadas. As respostas ao movimento anterior devem buscar variações de ritmo e intensidade, trabalhar as categorias de energia, ao receber o que foi lançado pelo par, p. ex. se o último movimento foi rápido e leve, reagir com um movimento lento e denso; achar a lógica das tensões para, na ajuda recíproca do trabalho com o outro, estabelecer uma relação que pode ser mantida e repetida; trabalhar com o "espaço sólido", como peças da engrenagem de um relógio, que quando uma se move as outras se movem de uma forma diferente. Há sempre o alerta para não se fixar em poses desnecessárias. Em seguida, após a definição da sequência de movimentos em três ações e três reações para cada um da dupla, o bastão é retirado, e o ator deve manter os mesmos impulsos, na repetição da partitura com seu partner. As duplas são, então, trocadas, para se achar novos estímulos de reação e estabelecer um diálogo, sem perder os movimentos de sua partitura original. Nessa fase, a dificuldade desse trabalho encontra-se justamente em, sem o objeto, não perder as tensões presenteadas pelo bastão, “a serpentina de tensões" conquistada pela manipulação do objeto e que se localiza, principalmente, na coluna vertebral. Observamos que as tensões, nesse caso, tendem a migrar excessivamente para os ombros e para as mãos, criando força desnecessária, que levam a perder a qualidade dinâmica da informação da espinha dorsal.

Em 2011, enquanto os atores trabalhavam em duplas, ocupando diversos espaços pelo gramado do Solar, em certo momento vi Barba no centro do galpão, sozinho, apoiado em um

${ }^{157}$ Physical Training at Odin Teatret, Odin Teatret Film, 1972. 
bastão, manipulando-o discretamente, entretido em pensamentos. Quando os atores voltaram para o local onde estava o diretor, após finalizarem suas improvisações com o elemento, brindou-nos com uma lembrança: "Cada vez que vejo um bastão, a saudade me agarra". Contou que quando chegaram os novos atores no Odin Teatret, na década de 1970, dos quais restaram quatro até hoje, deu-lhes como companhia um bastão. Os atores mais antigos estavam em excursões a fim de achar novos estímulos e aprender novas técnicas ${ }^{158}$, por vários lugares do mundo. $\mathrm{O}$ diretor pediu aos ingressantes que adornassem seus bastões, que os tratassem como se fosse um filho. Um totem de um antepassado. Que achassem o tipo de vida aquele golem tinha. Quando os antigos integrantes voltaram, conta ele, ficaram maravilhados com os resultados obtidos nas improvisações criadas. O bastão é para todos os atores do grupo um amigo, que os ajudou revelar qualidades físicas e os fez companhia, nas longas horas de treinamento.

Aliás, os objetos são sempre considerados "companheiros de trabalho" (VARLEY, 2010, p. 88) para os atores do Odin Teatret, e reconhecidos como uma entidade autônoma, com vontade e temperamento próprio (BARBA, 2010b, p.134). A lógica que se segue é a de lidar com o outro, sem atitudes imperialistas e com disposição para o diálogo, ouvindo e reagindo ao que o elemento tem a dizer. ${ }^{159}$

O trabalho com objetos promove, principalmente, o pretexto para as "ações reais", nas quais o trabalho do ator está concentrado em lidar com as qualidades matérias daquele objeto, tirando-o da tendência a querer "expressar" que está realizando algo. O "temperamento" do objeto ajuda o ator a reagir, estabelecendo diálogos físicos que o afastam de elaborações mentais desnecessárias. E ao objeto ser retirado, obriga o ator a trabalhar os princípios da omissão e equivalência, mantendo as qualidades dinâmicas conquistadas na ação.

\footnotetext{
${ }^{158}$ Encontramos esse período descrito em BARBA, 2009, p. 21.

159 Nas demonstrações de trabalho de Roberta Carreri e Jan Ferslev, durante a Odin Week 2013(25/08/2013), vimos exemplos desses tipos de relação explicitados na evolução do uso dos objetos e instrumentos musicais durante a criação. Carreri exemplifica como um xale, originalmente testado durante o processo que culminou no espetáculo Salt (2002), transformou-se em um lenço, e Ferslev demonstra como transformou a casca de um tatu em instrumento de corda usado no espetáculo Mythos (1998) e um violão infantil que virou um boneco, remetendo a uma criança morta no espetáculo Kaosmos (1993). Diz ele que é preciso achar diferentes propósitos para o mesmo objeto, diferentes formas de se aproximar dele, de tocá-lo e deixar espaço também para reações que pode provocar, como uma vontade de dançar que sentiu com os instrumentos usados em Itsi Bitsi (espetáculo ativo), por exemplo.
} 


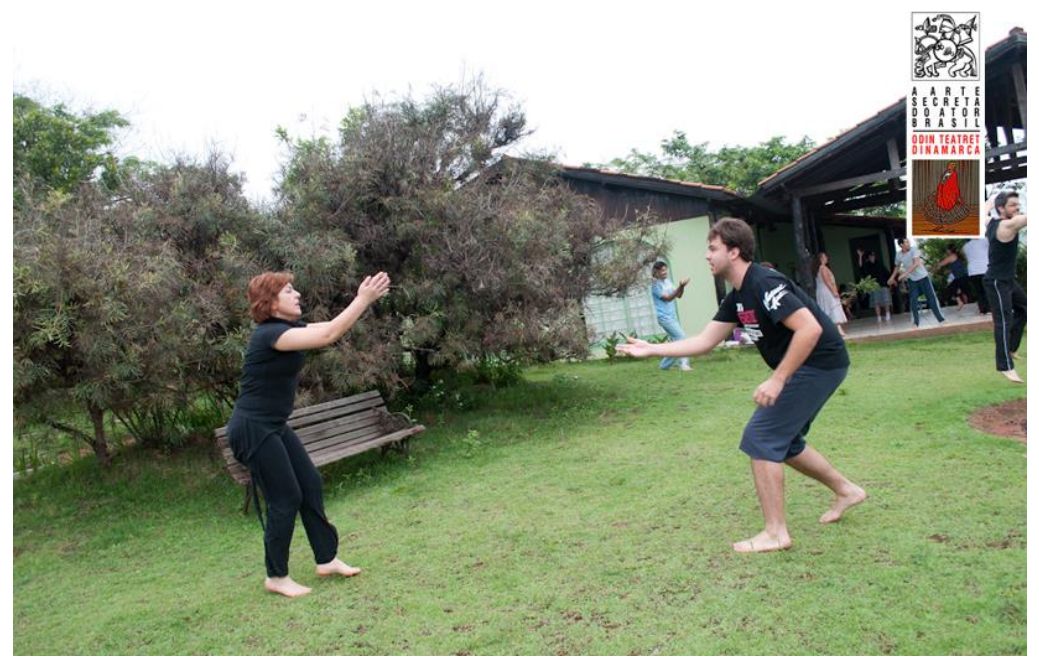

Figura 16. Lançamentos. A Arte Secreta do Ator - Brasil, 2010. Com George Gottheiner. Foto: Edu Barroso.

Também é recorrente, durante os treinamentos nos cursos, usarem objetos, como sapatos, (a exemplo do trabalho com o texto) para os atores experimentarem as tônicas corporais de lançamentos realizados primeiramente com os objetos em questão e depois os suprimindo, mantendo as tensões corporais achadas, além de sugestões subsequentes para lançamentos como uma pluma, uma pedra etc. Na figura 4 podemos ver uma dessas práticas em que o objeto foi suprimido. Em 2011, o mesmo elemento foi usado para ajudar os atores na criação de materiais. Barba sugeriu, a partir da dificuldade de um ator achar formas diferentes de caminhar, que um sapato descalçado fosse deslocado pelo pé do ator conforme caminhava, procurando tocar o objeto com partes distintas e percebendo o que mudava na dinâmica do andar, transferência de peso, imagens que surgiam internamente conforme as formas exploradas. Em seguida, aplicou o exercício com toda a turma, pedindo que selecionassem cinco modos de dar os passos, a partir da experiência. ${ }^{160}$ "O ator não caminha, ele dá um passo depois do outro" (BARBA, 2010b, p. 268). Achar a qualidade de cada passo traz informações ricas sobre as tensões necessárias ao corpo no deslocamento, recheando um simples andar de intenções ocultas, mas visíveis em sua forma no corpo do ator.

Na encenação, o uso de objetos para Barba deve ser justificado por no mínimo três aparições do mesmo elemento. Ele deve exercer funções diferentes, abrindo o leque de significações de seu uso na cena e ter diversas utilidades na narrativa.

${ }^{160}$ Assim, mais um material criou-se para os atores, aproveitado posteriormente em um exercício com Varley. (v. p.135, exercício 23). 


\subsubsection{A convivência com os mestres (uma licença para impressões e} adjetivos)

As trinta horas de curso oficial não dão conta da experiência de se estar literalmente 24h por 4 dias ${ }^{161}$ com Eugenio Barba e Julia Varley. Há solenidade e respeito por parte dos participantes e, ao mesmo tempo, o acolhimento por parte deles e a premissa de trabalho efetivo sobre as proposições do curso. Luciana Martuchelli e equipe primam pela organização cuidadosa e competente do encontro.

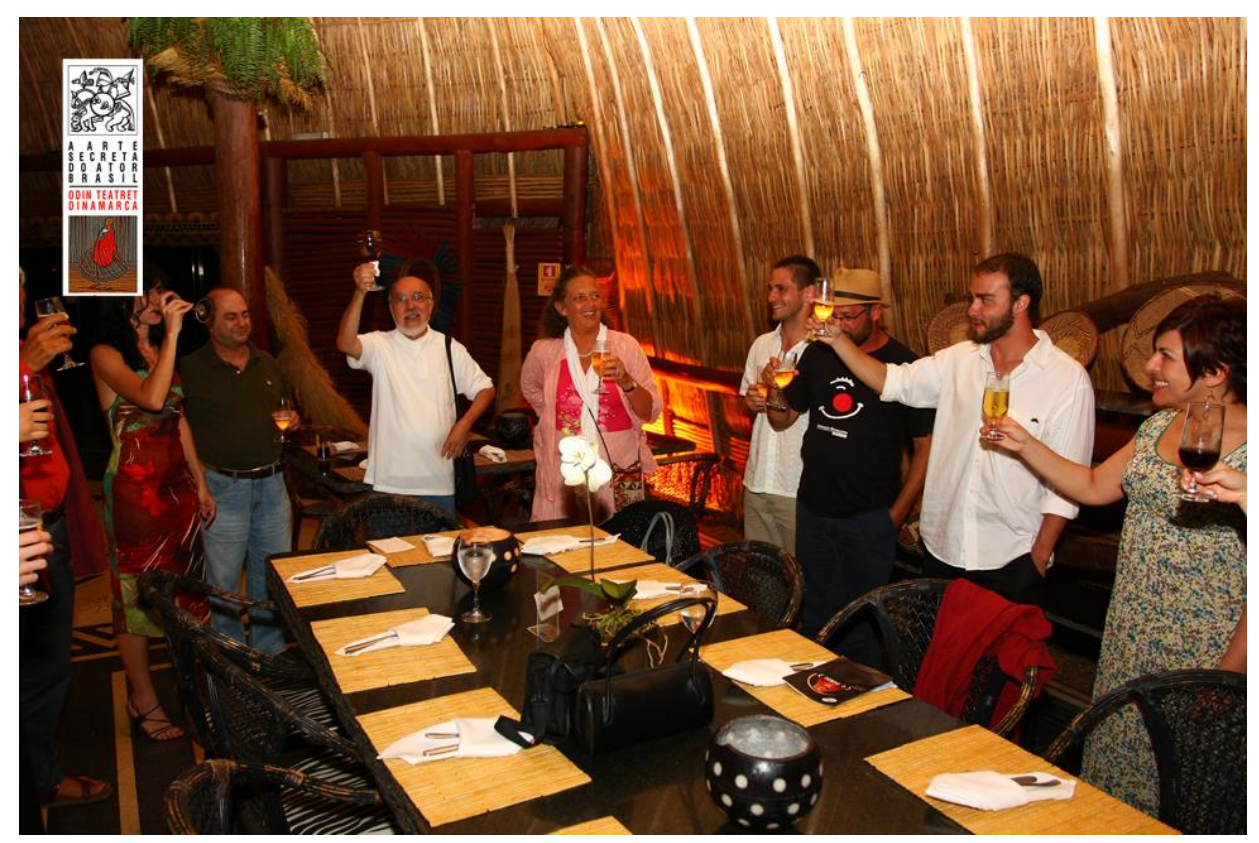

Figura 17. Celebração. A Arte Secreta do Ator - Brasil, 2009. Foto: Marcelo Dischinger.

Lembro-me de, no primeiro workshop do qual participei, Julia alertar-nos para que não fôssemos tão tímidos e realmente aproveitássemos suas presenças para tirar dúvidas e conversar com eles. No momento das refeições temos a oportunidade de nos sentar juntos e compartilhar as conversas e, mesmo, ter um approach mais pessoal.

Há sempre uma aura de profissionalismo os cercando; são muito cientes de seus papéis de artistas e pedagogos e o aproveitamento do tempo é integral. O rigor que desenvolveram por anos isolados em salas de ensaio é revelado em uma aparente energia inesgotável. São objetivos e ao mesmo tempo receptivos e sinceros. Barba tem um humor peculiar e um olhar excruciante. Parece estar sempre intrigado com algo e não há respostas prontas para esse diretor. A obsessividade com que trata cada detalhe é traduzida em uma paixão contagiante.

${ }^{161}$ No meu caso, por ter participado de quatro edições, 16 dias, o que corresponde à $384 \mathrm{~h}$. 
Penso que não é a toa que conseguiu reunir em torno de si tantas pessoas, e ainda hoje, arrasta multidões onde quer que vá. ${ }^{162}$

Varley transmite seriedade e ao mesmo tempo serenidade. Nas diversas ocasiões em que estive com ela, nunca a vi em um estado não-disponível ao diretor ou à escuta do trabalho de cada ator participante. Coloca-se com precisão e a disciplina e honestidade que se vê em seu corpo são frutos de sua total aplicação ao que faz. Frequentemente, me parece que se diverte internamente com algum acontecimento, e pelos olhos transborda generosidade e sabedoria.

Senti-me muitas vezes como abelha rondando flores cujo pólen é irresistível. Mas, com tantas abelhas em volta, é preciso o momento certo para se aproximar. Certa vez, em 2012, com um artigo em mãos sobre o trabalho do ator baseado nos dizeres de Barba, pedi a ele que o lesse. No dia seguinte, chamou-me e me devolveu os papéis com duas observações anotadas a lápis e com as palavras: "No mais, não há nada que me incomode." Pelo livro de Varley (2010, p. 88), que ouviu palavras parecidas sobre seu treinamento quando o submeteu ao diretor, tomei como um incentivo.

Em suas irradiantes presenças durante o trabalho demonstram também uma paciência infinita. Barba, certa vez, durante o curso em Brasília (2011), comentou que ele nem sempre foi assim tão paciente. ${ }^{163}$ Apesar de várias vezes exasperar-se em gestos ou tentativas de exemplo na falta de entendimento de um princípio ou de uma direção exaustivamente repetida e reformulada, nunca foi rude. Barba e Varley são extremamente claros e falam o que realmente pensam das performances, apontando caminhos para a solução de alguma cena e trabalhando incansavelmente com o ator, dando atenção a detalhes e fazendo ser verdade uma premissa que vem desde Stanislavski: nada é em geral, e sim, muito particular. A incrível capacidade objetiva e altamente poética de formularem os conceitos e as questões sempre me

\footnotetext{
${ }^{162}$ Um fato ocorrido por ocasião de sua palestra em São Paulo, no Teatro Sérgio Cardoso (06/05/2010), chama a atenção. Havia uma fila enorme para entrar no Teatro, pessoas estavam lá desde a manhã para garantir lugar. Pessoalmente tive sorte, pois cheguei uma hora antes da palestra e, na fila, eu e colegas fomos os últimos a entrar. Subindo as escadas, vi Barba em um dos lances, sozinho, observando o movimento. As pessoas passavam por ele e aparentemente não o enxergavam ao mesmo tempo em que estavam ávidas para ver Eugenio Barba falar. Parei para cumprimentá-lo. Ele, receptivo, falou-me: "Não sabia que eu tinha virado estrela do rock." Rimos atônitos. Depois da palestra iniciada, houve inclusive uma "invasão" por parte daqueles que não conseguiram entrar. Complementando, há uma transcrição informal desse evento disponível em: <http://redimunho.wordpress.com/2010/05/12/eugenio-barba/>. Acesso em: 18/01/2014.

${ }^{163}$ Ao que achamos referências, tanto em Varley (2010, p. 198) quanto em Carreri (2011, p. 183), que diz: "Mas foi durante os ensaios que Eugenio, efetivamente, formou seus atores, com uma paciência que considero ainda hoje extraordinária, ainda que gesticular e gritar não sejam alheios ao seu temperamento como diretor."
} 
foi tocante, sensibilizando não só a prática no momento das instruções, mas me falando à alma, tocando um lugar que ressoava em vontade e aplicação em perseguir suas orientações.

Das experiências com a ARTE SECRETA DO ATOR, nos cursos em contato direto com o pai da Antropologia Teatral e sua "filha", Julia Varley, inscreveram-se em mim a certeza do comprometimento com a dedicação ao que cada um se propõe, o reconhecimento da eterna efemeridade do fazer artístico, a sensação de tocar o inefável e, sobretudo, a compreensão celular do que é fazer bem feito através da dedicação ao que se acredita. E esse contato com os mestres aguçou a curiosidade para o passo seguinte da pesquisa de campo: conhecer a casa e outros membros do Odin Teatret na Dinamarca.

\subsection{Odin Week ${ }^{164}$}

Entre as vivências de campo durante a pesquisa inserem-se os dias passados em terras nórdicas, na sede do Odin Teatret, em Holstebro, Dinamarca. A “semana Odin" durou dez dias (edição 2013, de 19 a 29 de agosto). Com exceção da abertura, às 17h do primeiro dia, uma programação intensa, das $7 \mathrm{~h}^{165}$ às $22 \mathrm{~h}$, une pessoas do mundo todo na convivência com os donos da casa. As atividades são todas conduzidas em inglês, com ressalva a alguns espetáculos apresentados em dinamarquês, principalmente quando são abertos ao público externo. Mas a Babel de línguas entre os participantes é uma constante a ponto de falarmos em grupo misturando várias e, mesmo assim, nos entendermos. ${ }^{166}$

\footnotetext{
${ }^{164}$ Todas as falas dizem respeito a anotações pessoais sobre a Odin Week de 19 a 29 de agosto de 2013. Outras fontes eventuais serão apontadas conforme sua ocorrência.

165 Pela descrição do evento, as atividades oficiais, a partir do dia 21/08, começam às 7h15, mas Kai Bredholt, um dos atores do grupo, convidou a todos a chegar às $7 \mathrm{~h}$ para aquecimento antes do Running and Singing (Correndo e cantando) das $7 \mathrm{~h} 15$ às $8 \mathrm{~h}$. Comandada por ele, essa atividade incluía o aquecimento com exercícios de Yoga, corrida e canções ao ar livre no entorno da sede e "desaquecimento" com mais música e danças. Ver ANEXO B.

${ }^{166}$ Diz Barba em uma carta a Santiago Garcia, diretor de La Candelaria, grupo colombiano, por ocasião do aniversário de 35 anos do mesmo: "Uma Torre de Babel ao contrário: eis aqui uma boa definição do teatro." Original disponível em espanhol em:

<http://www.odinteatretarchives.com/MEDIA/DOCUMENTS/EB_LLANEZA_Y_VAIVEN.pdf> e tradução em português em: < http://www.nortea.com.br/Nortea/artigo-Mestres....html>. Acesso em 12/07/2014.
} 
$\mathrm{Na}$ tarde de chegada, fomos recepcionados na White Room, uma das salas de espetáculo do antigo galpão, o qual abrigava a criação de porcos e vacas, transformado em sede na metade dos anos 1960.

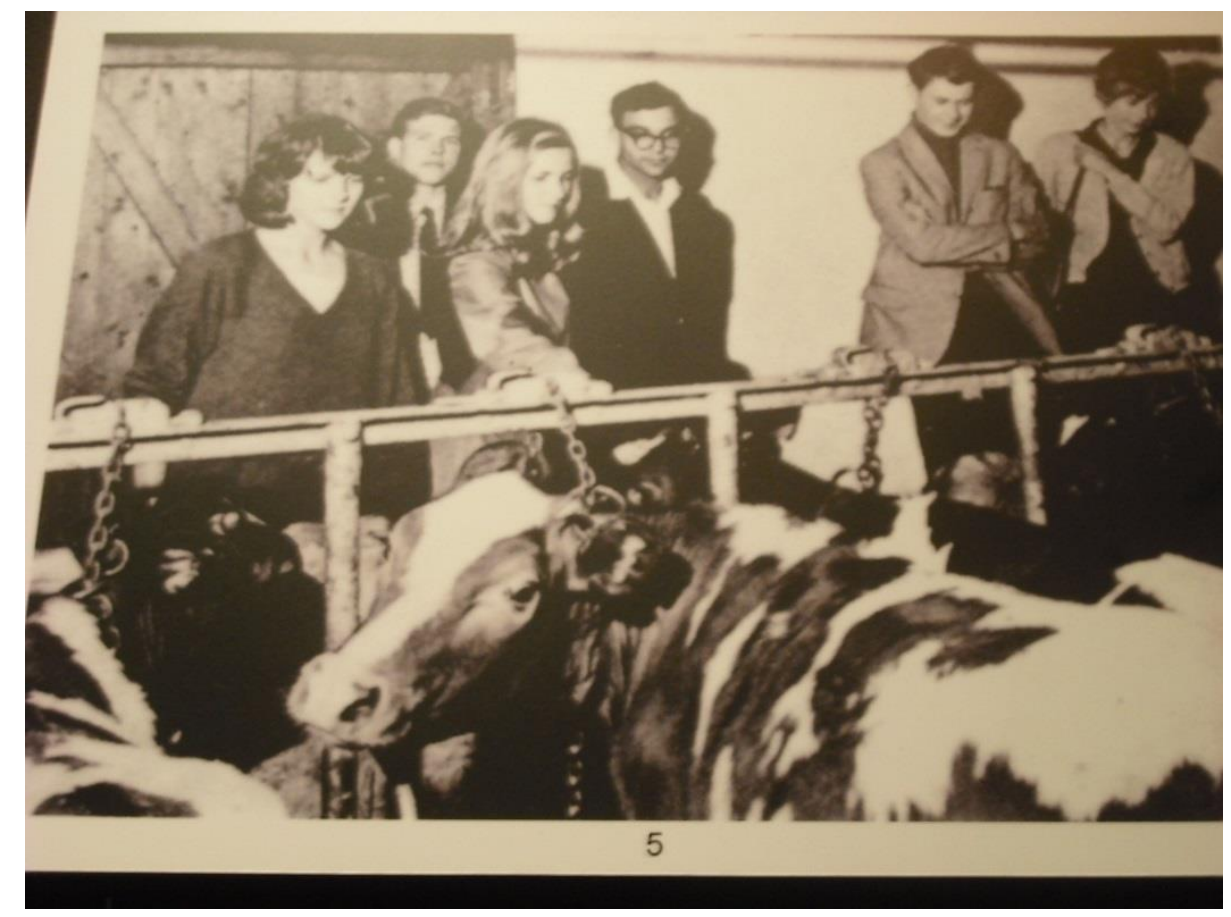

Figura 18. Foto da foto. Primeira visita ao local cedido em Holstebro para o Odin Teatret. Foto: Leticia Olivares por ocasião da exposição dos 50 anos do Odin Teatret em sua sede. Holstebro, Dinamarca, junho de 2014.

Ali aconteceu o primeiro Meeting com Eugenio ${ }^{167}$, no qual Barba, acolhendo os participantes, contou um pouco sobre a história do grupo, quis saber nome de cada um, de onde vinha e por que estava ali, além de nos convidar para o primeiro espetáculo da programação: A Vida Crônica, que aconteceria a seguir e nos atribuir uma tarefa: que escrevêssemos uma carta sobre o espetáculo para ele, principalmente aqueles que nunca haviam visto nenhuma encenação do grupo.

A minha carta ao diretor, escrita na mesma noite após eu ter assistido ao espetáculo, foi a seguinte:

\footnotetext{
${ }^{167} \mathrm{Na}$ maioria das tardes durante a Odin Week tínhamos encontros com Barba nos quais ele discorria sobre os princípios, a forma de trabalhar do grupo, histórias e lembranças sobre o tempo em que esteve com Grotowski e respondia a perguntas dos participantes.
} 


\section{CARTA A EUGENIO}

Holstebro, 19 de agosto de 2013.

Uma crônica sem fim

A vida só é possível reinventada. Anda o sol pelas campinas e passeia a mão dourada pelas águas, pelas folhas. . Ah! Tudo bolhas que vêm de fundas piscinas de ilusionismo... - mais nada. Mas a vida, a vida, a vida, a vida só é possível reinventada. Vem a lua, vem, retira as algemas dos meus braços. Projeto-me por espaços cheios da tua Figura. Tudo mentira! Mentira da lua, na noite escura. Não te encontro, não te alcanço... Só - no tempo equilibrada, desprendo-me do balanço que além do tempo me leva. Só - na treva fico: recebida e dada. Porque a vida, a vida, a vida, a vida só é possível reinventada.

Cecília Meireles, Reinvenção

Querido Eugenio,

Estar aqui, na casa de vocês é minha wonderland. Ao botar os pés no seu solo, venho sofrendo de constantes surtos de questionamentos, grandes acessos de responsabilidade galopante e crises convulsivas de alegria e agradecimento pela vida.

Ver em cena todo o elenco do Odin pela primeira vez, já que só tinha assistido aos espetáculos da brilhante Julia, também me provocou arrepios, engasgos, soluços... As reações físicas ainda se manifestavam em respirações retidas, sobre as quais me dava conta quando voltava a respirar depois de segundos.

O espetáculo é um soco no estômago, cheio de beleza e crueldade. Minha alma está pendurada em um dos ganchos do cenário até agora. Em suspensão, pinga sangue e lágrimas, como uma peça de carne no açougue após uma morte súbita e inexplicável.

A vida, tomada em vícios de comportamento de cada personagem, parece seguir um destino de cartas marcadas... Pergunto-me, é possível mudar o que estamos tão acostumados a fazer? Ou a vida é uma doença causadora de repetições de padrões que aprendemos sem querer, herdados de nossos pais, avós, sociedade, país...?

Na minha retina fixaram-se imagens suspensas no tempo-espaço: um anjo cego, a bandeira que se faz abrigo, que se faz útero, que é mortalha. Um container contém asas quebradas. A mutilação. O mascaramento.

Quem é esse corvo que nos ronda? Quais as cartas que estão marcadas? Jogadas ao vento, por que sempre são as mesmas recolhidas?

O sagrado coração sangra. Por quem, mesmo? E por que, por que tem que continuar sangrando enquanto nos debatemos em mediocridades, em guerras e ilusões vãs? 
Em nossos castelos de cartas, portas sem fechaduras nos lembram de que, nem se batermos muito fortemente, elas se abrirão. Isso porque já estamos lá dentro. Só não percebemos. E quando conseguirmos entrar, na verdade estaremos saindo, quem sabe além de nossos vícios de comportamento e de nossa cegueira.

Uma crônica, além de caracterizar uma condição continuada de um estado, que pode ser uma doença, é também um gênero narrativo, uma forma de contar fatos. A vida contada pelo Odin Teatret trouxe-me um dejà vu de uma história milenar, que ressoa em mim como uma antiga recordação. No entanto, é uma nova história, escrita por cada um em suas particularidades. Tão diferentes e tão iguais. Há uma saída? A vida sempre oferece portas. Por qual vamos entrar? E sair?

Esta é uma carta sem fim, porque as portas estão escancaradas agora! Ainda irei me perder entre elas, tateando um pouco mais... Porém não estou cega. A vida, mostrada por vocês, me faz enxergar...

Um grande e caloroso abraço,

Leticia

O gosto de Barba por cartas remete a uma época em que essa era a forma de comunicação entre as pessoas. Ele manteve constante troca de missivas com Grotowski, atores do Odin Teatret ${ }^{168}$ e colaboradores teóricos do mundo todo. Esclarece que é um costume pedir aos seus espectadores que escrevam para ele sobre os espetáculos, contandonos que, certa vez, pediu para crianças desenharem sobre o que tinham assistido e também soldados para assistir Vida Crônica e falarem sobre a cena da bandeira, pois estava preocupado com ela. Interessa-se pelas respostas dos espectadores e ao mesmo tempo sabe que não deve dirigir "intelectualmente" o que está fazendo. Deduz que é impossível saber para quem será relevante o espetáculo, mas busca, ao proporcionar a experiência dramática, a beleza que contém verdade e sabe que a verdade pode fazer sofrer. Conclui: "O quer dizem sobre o teatro é uma forma de ilusão. A performance vive no espectador por um tempo. Depois o que ele vai lembrar é a emoção que sentiu." "169 O setor de arquivos do Odin Teatret (OTA - Odin Teatret Archives) tem uma seção secreta, não aberta ao público, destinada a

\footnotetext{
${ }^{168}$ A Carta ao ator D. na qual questiona as necessidades pessoais de um ator e sua relação com o próprio ofício é famosa, sendo um dos textos mais difundidos de Barba (2010a, p. 37).

${ }^{169}$ Anotações pessoais Meeting com Eugenio, 27/08/2013. Holstebro, Dinamarca.
} 
guardar as correspondências de Barba com vários artistas, estudiosos e amigos trocadas ao longo de sua vida. ${ }^{170}$

Antes de finalizar o primeiro encontro, Barba nos alerta: "Não se deixem seduzir." A atitude crítica que nos cobra é a que se vê no diretor, refutando qualquer deslumbramento sobre as próprias conquistas, sobre o alcance e sucesso do grupo, sobre resultados préestabelecidos.

Entre centenas de inscrições, ${ }^{171}$ cerca de 70 pessoas selecionadas respiravam o mesmo ar do espaço sagrado que é o Odin Teatret. Essa sensação começa já na alameda de pedrinhas, com árvores "vestidas" com faixas vermelhas e amarelas, que leva até sede. O som dos passos aguça os sentidos e a curiosidade. Chama à atenção uma torre branca, à direita de quem chega, construída posteriormente ao galpão original, que faz parte do local destinado aos arquivos. O bem cuidado pátio da entrada, com um banco convidativo e vários detalhes a serem notados, desde os cinzeiros em forma de leão, esculturas nos telhados, flores no jardim (era verão quando estive lá) e o símbolo do grupo à entrada da porta principal, envolvem os recém-chegados, colocando-nos frente-a-frente com prédio principal.

\footnotetext{
170 “The OTA also keep Eugenio Barba's correspondence which is not yet accessible for obvious motives of privacy but which, when available in the future, will make it possible to reconstruct relationships, shared problems, topics, reflections and phases of development concerning Odin Teatret and the milieu of which it is a part and a catalyst." Disponível em: <http://www.odinteatretarchives.com/thearchives/the-documentarchives/441>. Acesso em: 07/05/2014.

${ }^{171}$ Informação oral. Segundo Barba, os selecionados são os 50 primeiros inscritos. Naquele ano, no entanto, abriram mais vagas chegando a 69 pessoas recebidas. Anotação pessoal, Odin Week, Holstebro, Dinamarca, 19/08/2013. Notamos que houve um grande número de participantes chineses, reflexo do sucesso que o grupo estava fazendo na China, naquele ano, em ampla programação em colaboração com o Wuzhen Theatre Festival e a Shanghai Theatre Academy. Disponível em: <http://odinteatret.dk/arrangementer/2013/maj-2013/odin-teatretin-china---full-programme.aspx>. Acesso em: 22/04/2014.
} 


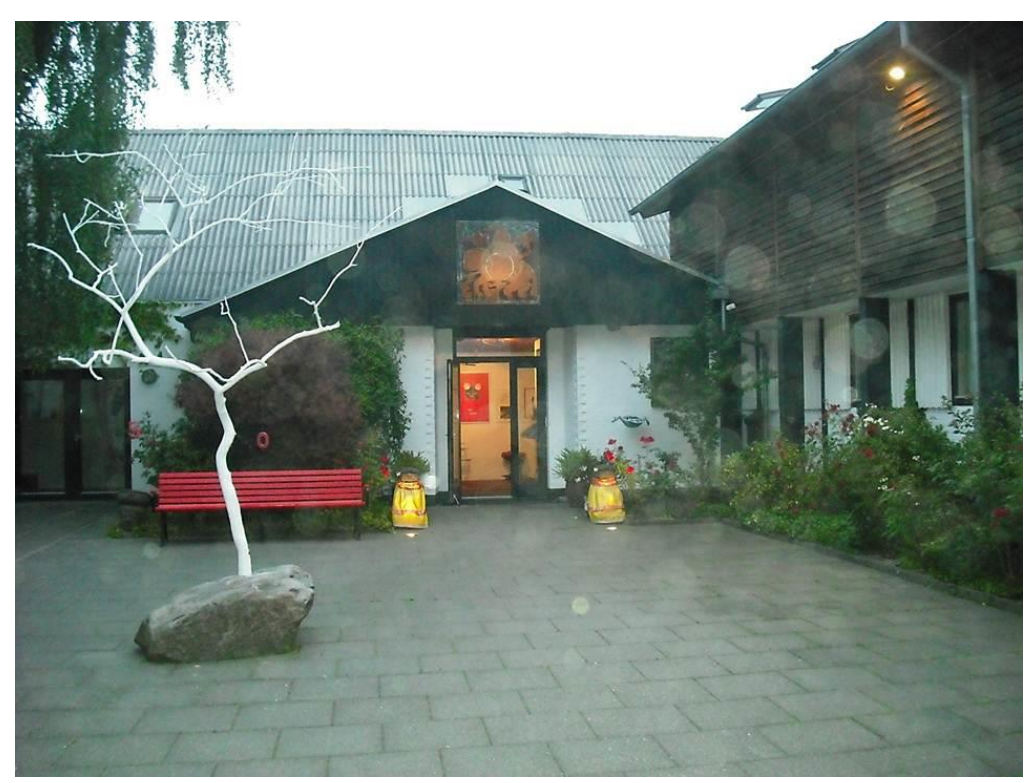

Figura 19. Entrada principal da sede. Odin Teatret, Holstebro, Dinamarca, 24/06/2014. Foto: Leticia Olivares.

A sede abriga ainda três teatros, chamados de White Room, Dark Room e Red Room, contando com um quarto espaço menor, a Blue Room, usada também para ensaios e apresentações. Há muitos quartos ${ }^{172}$ e banheiros, escritórios dos integrantes, cozinhas, lavanderia, biblioteca, videoteca, galpão de marcenaria e locais de armazenamento para equipamentos. Em cada canto há detalhes e referências aos espetáculos, como cartazes emoldurados e a viagens, como pequenas estatuetas ou objetos da América Central, também máscaras de várias tradições orientais que adornam as paredes. No entanto, nada parece excessivo ou kitsch, no sentido de mau-gosto. É um ambiente acolhedor e convidativo ao olhar, cheio de história transbordando de cada elemento, o que o torna vivo e borbulhante. ${ }^{173}$

Roberta Carreri, a idealizadora dessa semana de recepção ${ }^{174}$ aos interessados no grupo, é a hostess e responsável pela apresentação do ensemble, das regras do espaço e convivência e das funções que cada visitante terá durante sua estadia. A manutenção da limpeza do espaço

\footnotetext{
${ }^{172}$ Há dois cômodos que são particularmente conhecidos entre os quartos: o dormitório onde Grotowski ficava quando em visita ao grupo e a Torre Sanjukta Panigrahi (1944-1997), construída em homenagem à dançarina indiana, colaboradora da ISTA e grande amiga do grupo. A torre proporciona uma visão $360^{\circ}$ do entorno, através de várias janelas em seu diâmetro.

${ }^{173}$ Nas duas vezes em que estive lá, deliciei-me em descobrir detalhes da "decoração" e imaginar a procedência de cada coisa, quem a teria ganho (ou quem os havia presenteado), comprado ou escolhido o local de colocá-la, povoando minha mente com histórias inventadas sobre as viagens e afetos que cada objeto guardava.

${ }^{174}$ Sem poder acompanhar as turnês, devido a pouca idade de sua filha, Carreri teve a ideia de organizar esse novo formato pedagógico que a permitia ficar em Holstebro trabalhando na sede do grupo. (CARRERI, 2010, p. 132).
} 
ficam a cargo dos participantes, com tarefas específicas como aspirar o foyer, limpar os teatros, colocar para lavar e secar os panos usados na limpeza, ${ }^{175}$ preparar o café da manhã, ${ }^{176}$ entre outras que assegurem a organização e bom funcionamento com tantas pessoas circulando. As tarefas, aliás, não são diferentes das que eles próprios cumprem há cinquenta anos. Não há uma cleaner-lady (faxineira, em tradução livre), como nos diz Roberta. O empenho em manter o espaço é de cada um que lá trabalha, configurando a coexistência no comprometimento das tarefas cotidianas que fazem parte dessa relação arte-vida, mantida há tantos anos. O silêncio ${ }^{177}$ é prerrogativa nos corredores, pois, mesmo que não estejamos em atividade, alguém pode estar ensaiando nas salas de espetáculos ou montando as próximas apresentações. As salas possuem uma placa que indica a interdição das mesmas: se estiverem viradas para o lado vermelho, não se pode entrar. Aliás, não é permitido nunca entrar após as atividades iniciadas. Tamanha austeridade não parece ser um sacrifício, mas sim fazer parte da coerência que cerca todo o ambiente e seus integrantes.

A programação das atividades envolve treinamentos com os atores do grupo, demonstrações de trabalho, apresentação de espetáculos ${ }^{178}$, os já mencionados encontros com Barba e ainda contempla passeios guiados na cidade e em uma praia, que foi cenário de uma cena antológica para o grupo, contada por Carreri: a excursão organizada por Augusto Omulú (1963-2013) até os fiordes dessa praia. Omulú, integrante brasileiro do Odin Teatret por onze anos, levou todos para jogar flores no mar em homenagem à Yemanjá em pleno dia 02 de fevereiro (dia desse orixá, na cultura afro-brasileira), mês de frio intenso na Dinamarca. ${ }^{179}$

\footnotetext{
${ }^{175}$ Essa foi a minha tarefa durante a estadia.

${ }^{176}$ Entre as várias cafeteiras disponíveis, uma era sempre usada pelos brasileiros e italianos, que gostavam do café mais forte, gerando a procura de outros participantes também para tomar um café mais "encorpado". Durante a intensa programação, o café foi combustível para combater o cansaço. Ainda, durante a segunda visita, no Festuge, o tempo que eu passava nos arquivos ou na biblioteca, tem o odor de café, constantemente em ebulição, atraindo as pessoas para a cozinha, a fim de uma pausa no ritmo intenso de trabalho em que estavam todos.

${ }^{177}$ Chamaram-me a atenção quanto a isso, principalmente durante o Festuge, no ano seguinte, uma porta pesada - no acesso à biblioteca - que ao fechar geralmente bate com um estrondo, e conversas em italiano, que também contrastam com a atmosfera, por seu tom tipicamente alto.
}

${ }^{178}$ Os espetáculos assistidos foram A vida crônica, Dentro do esqueleto da Baleia, Judith, Salt, Castelo de Holstebro II, Itsi Bitsi, O livro de Ester, Memória. E as demonstrações de trabalho, Traces in the snow, Nora's way (Roberta Carreri); Letter to the wind (Jan Ferslev e Roberta Carreri); The death brother, The eco of Silence (Julia Varley); My stage children (Else Marie Laukvik); Text, actions, relations (Julia Varley e Tage Larsen); Quasi Orpheus: The actor musican (Jan Ferslev); The whispering winds In Theatre and Dance (Kai Bredholt, Roberta Carreri, Jan Ferslev,Tage Larsen, Iben Nagel Rasmussen, Julia Varley, Frans Winther).

179 Julia Varley também conta essa passagem em Uma Carta para recordar para Omulú, por ocasião de sua morte, em 2013. Disponível em: <http://performatus.net/uma-carta-para-recordar/〉. Acesso em 21/04/2014. 
As tradições, tomadas como os exercícios experimentados e as demonstrações de trabalho, que apresentam os processos de construção cênica de cada ator, serão abordados no Capítulo III.

No Meeting com Eugenio do dia 22 de agosto, Barba, após pontuar a reação que percebia em muitos de nós, que não contínhamos as lágrimas durante os espetáculos assistidos, apesar de seu alerta para sermos críticos, nos pergunta, intrigado: como um ator alcança esse efeito? Como é capaz de chegar nesse nível do emocional do espectador? Como resposta indireta, assistimos ao trabalho do diretor com os atores Donald Kitt, Sofia Monsalve e Elena Floris. Ao som da Cantiga do Sapo ${ }^{180}$, os atores entram em cena dançando. Dois deles estão em pernas-de pau e Floris toca violino, todos como a personagem Andrógina. Barba irá trabalhar longamente sobre os impulsos das ações, quebrando a previsibilidade dos deslocamentos através de mudanças de direção, diferentes passos e formas de saltar e exploração das possibilidades dinâmicas, para criar, nas transferências de peso, "a dança das reações". Ao trabalhar como "coreógrafo" das ações, seguindo e não seguindo a música, Barba procura destruir as sensações rítmicas que possam se tornar repetitivas para o espectador, gerando pequenos estranhamentos ${ }^{181}$, sem descuidar, no entanto que depois de ações incompreensíveis, um signo seja distinguível para quem assiste, gratificando-o e incrementando seu interesse. O diretor cumpre o papel de avaliar o que chegará ao espectador, identificando clichês e os transformando para chegar a arquétipos ou signos que serão reconhecidos pelos espectadores. Barba reafirma, nesse processo, que não é bom em imaginar resultados prévios e que trabalha com os materiais que seus atores lhe dão.

Mas essa forma de demonstrar como trabalhar a técnica é sempre permeada com as considerações sobre a relação dos atores com sua biografia, seu diálogo interior, o passado e o presente de cada um, a relação espaço e tempo e articulação dos próprios materiais, do texto, e a constatação, por sua prática, de que o treinamento também serve para treinar essas relações. Um conselho é que o ator nomine o que está fazendo, para tornar claro a si mesmo o

\footnotetext{
180 É assim que o sapo canta na lagoa/ Sua toada improvisada em dez pés/ Tião?, oi, "foste"?, fui, “Compraste'”?, comprei, “pagaste'’?, paguei/ Me diz quanto foi: Foi 500 rés/ É tão gostoso morar lá na roça/ Numa palhoça perto da beira do rio/ Quando a chuva cai o sapo fica contente/ Que até alegra a gente com seu desafio. Au. Buco do Pandeiro, Jackson do Pandeiro. Intérprete: Alceu Valença. Disponível em: <http://www.alceuvalenca.com.br/musica/?CodFaixa=225>. Consulta em: 06/05/2014.

${ }^{181} \mathrm{O}$ que ele chama às vezes de hiccups (soluços). Ver n.r. 137, p.72.
} 
procedimento ou sensação. ${ }^{182}$ Salienta que o processo que o ator passará em seu treinamento pessoal e na lógica interna da construção dos materiais não será visível para o espectador, a não ser pelas reações que causará, como as que tivemos ao assistir aos espetáculos.

Barba $^{183}$ irá sempre desafiar os atores a acharem o que lhes funciona no caminho da individuação da técnica, a lutar pelas próprias soluções, enfatizando as perguntas que devemos nos fazer constantemente: "Como, onde, por que e para quem estou fazendo teatro?" Ressalta que, ao aprender com os mestres e copiá-los, a armadilha é achar que simplesmente se alcançará resultados iguais. Ao mesmo tempo, valoriza a imitação como estágio inicial anterior à personalização, salientando que muitas vezes, a cobrança por "originalidade" tolhe e angustia o ator em seu processo de aprendizado. Neste ponto, uma breve anotação em meu diário remete a um ditado zen que ouvi certa vez: "Se você encontrar o Buda no caminho, mate o Buda." Essa anotação está junto à outras falas de Barba: "Grotowski ajudou-me a encontrar meu caminho." e "O pupilo deve subir nos ombros do mestre e enxergar além." Essa busca constante pela identidade, reforçada pela força dos mestres que encontramos e nos influenciam, é uma das lições que não me canso revisitar: aprender a aprender, repetindo o ensinamento de Barba para mim mesma como caminho de depuração das informações. Outra anotação do diário diz respeito a isso: "Não é o método que é aplicado que é importante. Mais importante é o professor. E mais ainda, o pupilo, que tem que saber como aprender."

Uma das dificuldades maiores de quem está sob a influência de uma estética como a do Odin Teatret ou de seus procedimentos pode ser libertar-se do modelo e achar sua própria aplicação das diretrizes. Muitas vezes, o emprego simples de partituras físicas e vocais conduz a resultados formais e vazios. Nas entrevistas com os atores, ao perguntar-lhes sobre o que achavam que não funciona no "método" me responderam que veem pessoas que aprendem com o Odin Teatret e simplesmente aplicam os procedimentos como "tática", criando alguns "Frankensteins" desconjuntados. Em entrevista, disse-me Varley: “Às vezes falo para

\footnotetext{
182 Interessante relacionar a uma orientação parecida que tive nos anos 1990 através de Klauss Vianna (19281992) e Neide Neves durante o curso da técnica dele e que me fez muito sentido, sendo adotada desde lá como procedimento pessoal e orientação que dou a meus alunos, como forma de registro de descobertas e capacidade de acessá-las: Nomeie para si mesmo o que descobriu. Crie arquivos pessoais de registros; é como geralmente passo essa informação.
}

${ }^{183}$ No trecho a seguir misturam-se anotações do Meeting com Eugenio do dia 25/08/2013. 
Eugenio que não deveríamos mais ensinar", ${ }^{184}$ ao assistir a "resultados" da aplicação dos ensinamentos.

Ferslev resume:

Tem várias pessoas, às vezes grupos jovens, mas até diretores, que foram fazer experiências com o Odin e querem trabalhar dessa forma. E é horrível de ver, porque, como disse [no curso], você tem que justificar; não é só falar com uma voz estranha, ou fazer coisas estranhas, você tem que ter essas imagens dentro de você, e justificar tudo isso... O porquê, como é a situação, o que estou fazendo, a motivação, pra tudo isso que é importante. E no final o diretor tem que entrar e ver: o que funciona? O que funciona para mim? Se funciona para mim acho que também funciona para os outros. E não ficar só na forma, porque está bonito ou causa estranheza um modo de falar. Tem que ser justificado internamente para o ator. Assim é ruim de ver pessoas que não entenderam isso. ${ }^{185}$

Tomando a visão de Sofia Monsalve, jovem atriz, pupila de Rasmussen, integrada ao grupo na montagem de Vida Crônica, temos também uma reflexão sobre os resultados da cópia:

[...] às vezes, quando vejo coisas que estão baseadas no método do Odin, [elas] não funcionam. Gosto muito mais de ver espetáculos de teatro que não têm nada a ver, mas que têm uma busca própria, do que espetáculos que buscam ações físicas, mas que não funcionam $[. . ..]{ }^{186}$

\title{
Winther contrabalança:
}

\begin{abstract}
A herança é a disciplina, nem tanto as técnicas em si, mas a disciplina que é necessária para levar a sério o que você está fazendo, ser preciso, fazer o máximo que você pode fazer. Não é preciso ter medo de estar copiando no começo, isso quer dizer, você não tem que ser responsável por inventar sua própria técnica o tempo todo, mas com o tempo, é claro, todos tendem a tornar a técnica mais pessoal. [...] copiar as coisas sem se preocupar que sejam cópias, pois o que acontece depois de um tempo é que não serão mais uma cópia. Porque no final você tem que fazer do seu jeito e vai desenvolver novas formas de fazê-las. [...] O que eu acho mais interessante sobre os ensinamentos do Odin é isso, a disciplina, a criatividade de como repetir várias vezes as mesmas coisas. ${ }^{187}$
\end{abstract}

Sobre o peso da tradição e dos caminhos percorridos para a compreensão dos ensinamentos, tomamos novamente Monsalve:

\footnotetext{
${ }^{184}$ Entrevista realizada em 23/08/2013. Odin Week, Holstebro, Dinamarca.

${ }^{185}$ Entrevista concedida a mim por Ferslev, USP, São Paulo, 29/10/2013.

${ }^{186}$ Entrevista concedida a mim por Monsalve em São Paulo, 03/11/2013.

${ }^{187}$ Entrevista realizada em 24/08/2013. Odin Week, Holstebro, Dinamarca.
} 
Digamos que é uma dificuldade na qual eu me encontro agora mesmo. Como encontrar qual é o seu treinamento pessoal e qual é a forma que funciona para você? Bom, eu entendo que ela [Iben] ensina sempre para que você descubra isso. Ela não te mostra a forma, mas te acompanha no caminho. E te acompanha te olhando por horas e horas e te diz apenas umas pequenas coisas, mas sempre propícias a que seja da sua maneira. E te dá alguns conselhos técnicos, tira dúvidas... Mas não é isso. Ela te dá total abertura para o que você é, o que para você funciona, como você se adapta. Então, eu trato de abordar o trabalho com as partituras físicas e, em muitas vezes, me encontro em extrema dificuldade, sobretudo para fixar as ações, por exemplo, porque para eles é isso é super essencial. ${ }^{188}$

Barba defenderá que achar a própria diferença é criar a sua identidade. Para manteremse vivos e criativos durante cinquenta anos, relaciona as experiências que tiveram que encarar, desde a rejeição, à possibilidade de pagar os atores para que pudessem se concentrar no trabalho proposto pelo diretor, até a mudança de estrutura no grupo para manter seus atores com ele. ${ }^{189}$ Ele também reconhece no que chama de o "povo secreto do Odin", as pessoas que estão continuamente pesquisando e escrevendo sobre o grupo, um estímulo para continuarem, pois "os alimenta e faz com que se sintam importantes". 190

Há ainda que se ressaltar o corpo administrativo que também conhecemos em um encontro durante a programação. Com transparência e animação, falaram-nos sobre o orçamento do grupo (em torno de dois milhões de Euros por ano), os desafios em lidar com as exigências das produções, viagens etc. e a necessidade de desenvolverem novas habilidades o tempo todo. A organização, como em todos os setores, é impecável e, sem dúvida, a figura de Barba -também excelente administrador- envolve o sucesso das finanças e da gestão longeva do grupo.

Esse diretor, que dedicou seu tempo a realizar uma aproximação científica com a profissão para alcançar procedimentos pragmáticos para o ator e obter resultados junto aos espectadores, encerra um dos encontros falando de amor, gratidão e generosidade. Sente-se grato aos mestres que teve e pensa sempre em como devolver os ensinamentos. Essa preocupação com a transmissão é uma das características do grupo e um de seus pilares. Disse

$$
{ }^{188} \text { Op. cit.. }
$$

189 Conta Barba, na palestra de abertura da Arte Secreta do Ator (Tecer Relações - O ator de um Teatro Laboratório, 12/12/2012 - IESB, Brasília), Rasmussen "revoltou-se" e quis criar um grupo próprio. Para não perder a atriz, que lhe era tão cara, mudou a estrutura administrativa, na qual o Odin Teatret deixou de ser a atividade principal para integrar o Nordisk Teaterlaboratorium, guarda-chuva que abrigou também o Farfa, grupo fundado por Rasmussen. Anotação pessoal, referente ao evento citado. Ver ANEXO D, com a estrutura de atividades de grupo.

${ }^{190}$ Anotação pessoal. Meeting com Eugenio, 25/08/2013. 
ele: "Se alguém lhe perguntar o que você aprendeu nesses dez dias no Odin Teatret, gastando dinheiro e doando seu tempo para estar aqui, responda: aprendi sobre generosidade, sobre ser generoso."191 Após essa fala, transcrevo literalmente uma anotação de meu diário: “(Fica calado, de olhos fechados. Mexe lentamente os dedos; ninguém diz uma palavra. Levanta-se, pega a cadeira [em que estava sentado] e sai em silêncio. Barba é mestre dos efeitos que vêm do coração. Leva um tempo para as pessoas começarem a falar novamente...)". E faço aqui algumas considerações, remetendo-me ao testemunho desse momento. Barba ao falar de tal noção, da generosidade, considerou o dinheiro e tempo investidos, a nossa jornada à pequena cidade da Dinamarca. Mas me soou antes como reconhecimento do que ele mesmo vive todos os dias com seus atores e equipe em geral, pois se vê que tem noção do grau de exigência a que submete todos, da dura rotina autoimposta e o trabalho incessante a que todos se dedicam.

No último dia do curso ${ }^{192}$ os integrantes do grupo, junto a Barba, colocaram-se à disposição para uma conversa com os participantes. Sentados em meia-lua, frente à plateia exausta - e eles mesmos, cansados, mas com surpreendente energia, apesar da programação exigente, na qual ministraram aulas, realizaram demonstrações de trabalho, apresentaram espetáculos - abriram o derradeiro encontro para perguntas que talvez ainda existissem. Essas abundaram principalmente dos jovens que queriam saber sobre as dinâmicas internas do grupo, como p. ex. a respeito de desacordos no grupo e a forma de lidar com isso. Carreri salientou então um importante aspecto de convivência: nenhum dos atores é autorizado a falar diretamente com o companheiro sobre suas impressões pessoais a respeito de desempenhos durante ensaios ou apresentações. Quaisquer observações ou incômodos são transmitidos para o diretor, evitando a confrontação direta na sala de trabalho, tomada como um ambiente diferente da vida cotidiana. Ressalta também o aprendizado de "dar um tempo" antes de comentarem a performance, imediatamente depois das apresentações, permitindo que os problemas eventualmente ocorridos tenham seu assentamento e tomem a devida proporção, sendo, mais uma vez, que não há o costume de comentar sobre o desempenho do outro, mas sim sobre a encenação naquele dia. Há, por parte de todos, um claro aspecto de confiança no diretor, atribuída principalmente à qualidade de clareza que identificam em Barba. Respeito é a palavra que Larsen destaca; Varley chama à atenção sobre uma característica de convivência familiar, na qual não necessariamente a amizade está envolvida, mas o afeto sim. Rasmussen

\footnotetext{
191 Anotação pessoal de Renan Paini, ator brasileiro e estudante de teatro na Itália, na época, que generosamente compartilhou sua nota e permitiu que eu a usasse na dissertação.

${ }^{192}$ A seguir, anotações pessoais referentes ao dia 28/12/2013.
} 
declara que grandes problemas podem se tornar uma proposição que gera enfrentamento, desafio e novas soluções.

Em uma pergunta que questionava como a vida privada de cada um era possível no contexto das exigências do grupo, destacam a improvisação como recurso aos acontecimentos prementes que esta impõe. ${ }^{193}$ Barba é claro: tem a intenção de manter seus atores com ele, então sempre procura que as soluções sejam encontradas, mesmo que sejam diferentes da noção do que é comum. A velha e sempre nova premissa para a vida e o teatro é citada: "The show must go on". Relacionando a isso, em outra pergunta sobre o que é o teatro, uma das abordagens do grupo é que eles vêm defendendo as relações que este estabelece, seja na sua feitura, seja na apresentação. Diz Barba que subir pequenas montanha ou escalar o Everest está relacionado ao que é preciso a cada momento. A vida é também improvisação.

Helena Floris, em entrevista, ${ }^{194}$ relembra uma frase que ouviu de Barba "O impossível é somente o possível que leva mais tempo" e reflete:

[...] a herança do Odin, para mim, não diz respeito somente a algumas técnicas, ao treinamento, a novos pontos de vista sobre o teatro, a dramaturgia, mas, sobretudo, o ensinamento sobre um modo de pensar a sua vida de forma diferente. [...] O tipo de teatro que fazem mantém sua alma e mente continuamente concentrada. Quando estamos aqui e outras pessoas chegam para ficar um tempo, elas percebem que este espaço necessita de toda a sua atenção e concentração. Você pode imaginar o que é viver aqui e sentir isso todos os dias.

Na convivência com todos do Odin Teatret, mais uma vez as noções que permeiam a arte-vida, e implicam questões éticas do comportamento dessa forma de viver em grupo, ficam claras em uma construção diária que envolve as improvisações e o confronto com diferentes experiências, sem acomodação ou lamentação, mas antes, a profunda percepção de resistência dessa anacrônica ilha na qual o fazer teatral impulsiona todos seus habitantes.

\footnotetext{
193 Retomamos o exemplo já citado de quando Carreri engravidou, o que gerou adaptações para todo o grupo e para ela mesma, possibilitando a criação da Odin Week. (Ver CARRERI, 2011, p. 129-132).

${ }^{194}$ Entrevista realizada durante a Odin Week, 27/08/2013.
} 


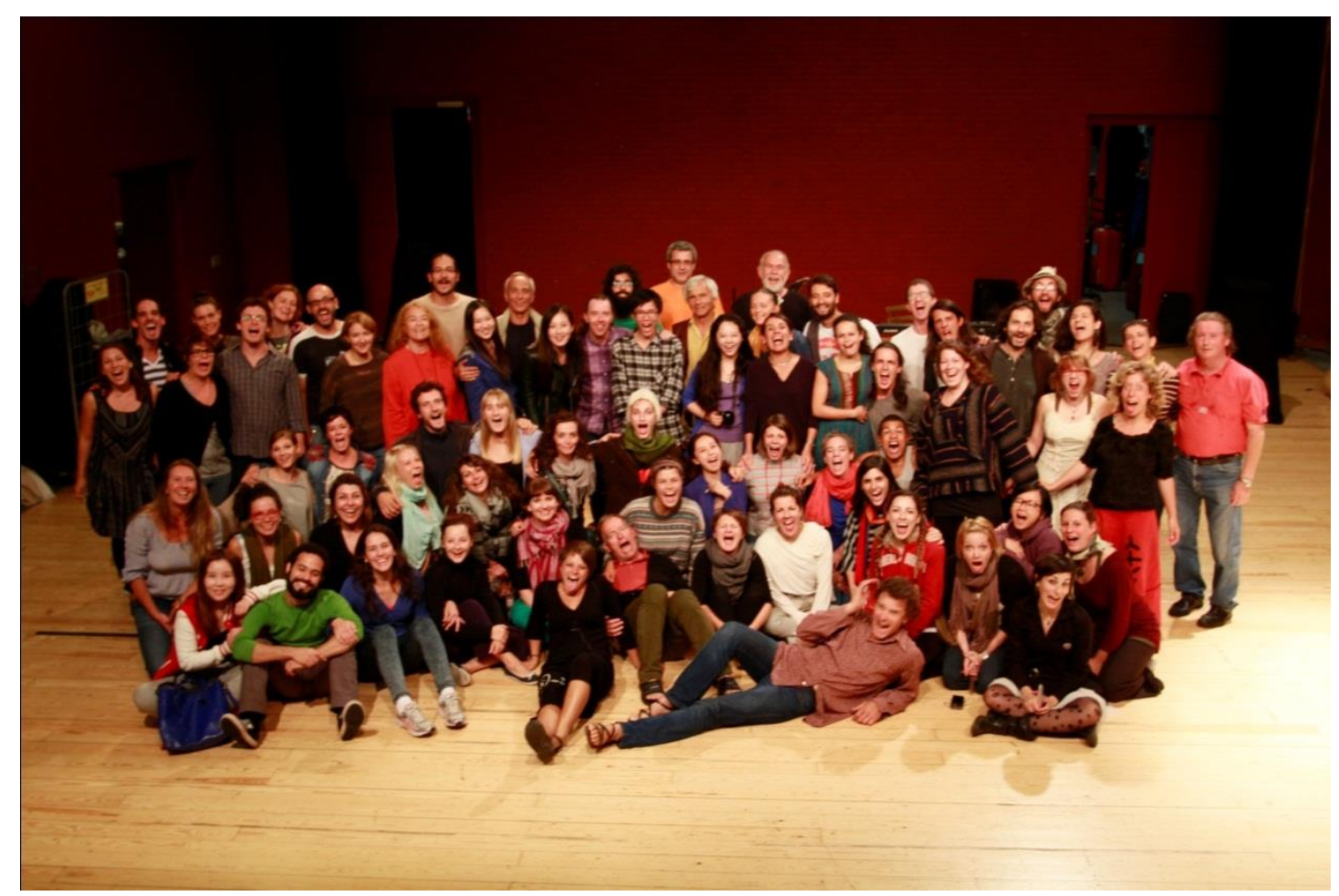

Figura 20. Turma multicultural da Odin Week 2013. Foto: Tommy Bay. 


\section{CAPÍTULO II}

\section{O DESVELAMENTO DO SER-ATOR ${ }^{195}$}

Art-speech is the only truth. An artist is usually a damned liar, but his art, if it be art, will tell you the truth of his day. And that is all that matters. Away with eternal truth.

D.H Lawrence

Pareceu-nos oportuna, além de poética, a noção de desvelamento tomada de Martin Heidegger ${ }^{196}$ para nomear este capítulo. Para ele o desvelamento acontece na existência relacionada à verdade, não como a visão platônica em que a "verdade é o desvelamento", mas como parte do fenômeno da Existência que erradica a verdade no momento da revelação de "si mesma enquanto maneira de ser própria", na qual a descoberta não é ela só, mas também o descoberto (MORA, 2004, p. 2994). Aproximando esse pensamento do fazer artístico, e especificamente do ator, trazemos pontualmente Gumbrecht (2010) - que toma aquele filósofo em suas considerações sobre a "produção da presença" - para dialogar com as questões sobre presença cênica. Assim vamos do efeito da presença às noções sobre a mesma, aproximando em seguida Stanislavski e Grotowski, além de Barba, nos preceitos sobre a sua aquisição técnica para chegar a considerações sobre o treinamento do ator. Permeamos as abordagens com Pavis e outros.

\subsection{Materialidade e sentido}

Hans Ulrich Gumbrecht, em seu livro Produção da Presença (2010), salienta as características da hermenêutica, a tradução interpretativa do acontecimento dominante na cultura ocidental, como uma perda da materialidade, da coisa em si. Sua defesa é que uma

\footnotetext{
${ }^{195}$ Há partes do capítulo baseadas em $O$ desvelamento do Ser-ator: primeiro ensaio, título de meu trabalho final desenvolvido para a disciplina Da pedagogia à cena, da cena à pedagogia [...], Prof. ${ }^{a}$ Dr. $^{a}$ Maria Thaís (ECAUSP, 2012).

${ }^{196}$ Mas não nos aprofundaremos na proposta filosófica do autor citado. Consideramos tal possibilidade para um futuro doutorado.
} 
cultura da presença, apesar de sempre se relacionar com o sentido ${ }^{197}$, daria novos pressupostos para os estudos em Humanidades, possibilitando uma relação mais complexa além da epistemologia metafísica; de ser-no-mundo capacitado a lidar com as relações também em nível espacial, e não apenas temporal, reconhecendo, na materialidade das coisas, uma referência além do sentido interpretativo (2010, p. 76). Apoiando-se principalmente em proposições de Heidegger, Gumbrecht (2010, p. 64-65) vai nomear, por sua vez, conceitos experimentais apresentados nas tipologias cultura da presença e cultura do sentido, como novas formas de lidar com o mundo. ${ }^{198}$ Vale salientar que Gumbrecht (p. 43) não vai anular uma pela outra, mas sim reivindicar um espaço para esse outro tipo de percepção dos acontecimentos, desprezados por um pensar ocidental que valoriza a posição central da atribuição de sentido. Portanto, a escolha em trazer as falas desse autor deveu-se a uma identificação com o que já acontece no teatro: a capacidade de borrar fronteiras entre presença e sentido na fricção com o acontecimento.

Especificamente, tomamos a experiência da produção da presença causada por atores do Teatro Nô, narrada por Gumbrecht (2010, p. 184), em sua caminhada até a cena ou na saída dela. No longo percurso pela ponte que o ator traça na direção ao palco, na qual a construção da personagem se dá entre idas e vindas de passos que denunciam a aquisição ou esfacelamento da forma das personagens. Essa característica também está comentada por Moriaki Watanabe, em um trecho de seu artigo Entre o Oriente e o Ocidente, pelo lento presentificar-se/ausentar-se dos atores, que gera um momento intermediário entre "o corpo cotidiano do ator" e "o corpo fictício da personagem", ao que ele vai chamar de corpo fictício, durante a passagem para o nível pré-expressivo (apud BARBA \& SAVARESE, 2012, p. 234). Esse tipo de passagem poderia corresponder à dimensão do desvelamento do Ser, adotada por Gumbrecht (2010, p. 96), que "[...] tem que perceber a si mesmo como um duplo movimento contínuo de vir para diante [...] e de se retirar [...], de revelação e ocultação.” Segundo o autor

\footnotetext{
${ }^{197}$ Fazem-se necessárias considerações sobre a palavra "sentido". Quando tratamos da acepção tomada por Gumbrecht, dirá respeito à tentativa de transliteração do que se observa. Aceitando que essa é uma operação que acontece no nível da linguagem, e, portanto, se rende a interpretações, permeadas dos pontos de vista de quem o faz, "sentido" diz respeito ao campo de atribuição de significados. Em português, sentido está relacionado também aos "cinco sentidos", capacidades sensórias do paladar, olfato, visão, audição e ao tato, sendo sinestésicas e atribuídas a um saber do corpo embora não estejam à parte da cultura que as modela. E sentido também pode nomear um ponto de vista, um estado de espírito ou uma direção. Consultamos dicionários da língua portuguesa disponíveis on line para esta elaboração.

${ }^{198}$ A "cultura de presença" propõe integrar as existências espiritual e física na autorreferência humana inscrita em uma cosmologia na qual o ser-no-mundo também faz parte de um mundo de objetos. A "cultura de sentido" está baseada na atribuição de significados a partir da separação ontológica entre sujeito e objeto e na tentativa de transformação baseadas na interpretação.
} 
(p. 93), a presença implica substância, relaciona-se com o espaço e se associa ao movimento. Em aproximação com o pensamento heideggeriano sobre o Ser, equipara-o à verdade, ou seja, no acontecimento da verdade, o Ser é aquilo que "ao mesmo tempo se revela e se oculta" em um movimento que "não é espiritual nem conceitual. Ser não é um sentido. Ser pertence à dimensão das coisas". Como ocupação no espaço, o Ser realiza um movimento tridimensional, associado a dimensões do estar, do dar-se a ver e do retirar-se (p. 94,95).

Ora, o papel do ator em sua presença é também de ausência; ao aproximar-se da personagem distancia-se de si. No entanto, como diz Barba (2012, p.17), é um oximoro, pois ao distanciar-se de si, revela a si mesmo na presentificação de um outro que ao mesmo tempo é e não é ele. ${ }^{199}$ Seja pela via que for, o papel do ator (ou o ator em seu papel?), diante de uma proposta de "materialidade da comunicação" "200 é de também provocar sensações que cheguem ao corpo do espectador. Produzir "momentos de intensidade"201. Gumbrecht vai descrever como "calma" a sensação ao contemplar um espetáculo de Nô, uma capacidade de simplesmente deixar vir e parar "de perguntar o que essas coisas querem dizer - pois elas parecem apenas presentes e plenas de sentido." ${ }^{202}$ Barba $(2006$, p. 74) ao se referir aos espetáculos de Katakali que assistiu, experenciava essa materialidade. Sem fazer o menor sentido, por não entender as convenções nem a língua, eles o arrebataram cinestesicamente. Durante a Arte Secreta do Ator (2012) Barba formulou: "Quando se diz que a arte é liberdade, quando se experimenta, na fricção de uma obra de arte, essa sensação, não é uma metáfora. É verdade. Porque o que nos atrai é o reconhecimento e, ao mesmo tempo, a quebra de nossos automatismos.",203

Podemos dizer que as ações e o que está oculto sob elas, provocam tanto a cinestesia quanto a sinestesia, ${ }^{204}$ no espectador, unindo materialidade e sentido.

\footnotetext{
${ }^{199}$ Acredito que esse paradoxo vai se explicitar mais contemporaneamente em fronteiras borradas de uma vidaarte, na performance art, por exemplo.

200 "Materialidades da Comunicação são todos os fenômenos e condições que contribuem para a produção de sentido, sem serem eles mesmos, sentido." (GUMBRECHT, 2010, p. 28).

${ }^{201}$ Ibidem, p. 125

202 Ibidem, p. 184.

${ }^{203}$ Anotação pessoal. A Arte Secreta do Ator-Brasil, Brasília, 15/12/2012.

${ }^{204} \mathrm{O}$ termo cinestesia está ligado ao sentido muscular e à percepção dos movimentos. Já sinestesia, segundo o dicionário Michaelis é a "Sensação secundária que acompanha uma percepção. Sensação em um lugar, devida a um estímulo em outro. Condição em que a impressão de um sentido é percebida como sensação de outro."
} 
Quem já assistiu a um espetáculo do Odin Teatret muitas vezes lida com uma dificuldade em relação ao "o que se quer dizer". Nota Barba, no programa do espetáculo $A$ Vida Crônica: "Me dizem frequentemente que meus espetáculos não são muito compreensíveis. ${ }^{205}$ Tirando a incompreensibilidade óbvia, e proposital, das múltiplas línguas faladas nos espetáculos, fruto primeiramente da formação multicultural do grupo, com atores de várias nacionalidades, mas depois elemento de estranhamento pretendido, temos as estratégias dramatúrgicas usadas por Barba. Watson (1993, p. 100) chama de "dramaturgia fragmentada" (fragmented dramaturgy) ao processo dos atores e diretor do Odin Teatret na construção das encenações. O que Barba chama de montagem, a combinação entre os elementos físicos, vocais, textuais e musicais (WATSON, 1993, p. 87), é usado para entrelaçar os materiais, como as ações dos atores, p.ex, seguindo duas formas (BARBA \& SAVARESE, 2012, p. 162): "numa sucessão em que uma ação parece estar respondendo à outra ou num acontecimento simultâneo, no qual o sentido de cada ação deriva diretamente do fato de que estão presentes ao mesmo tempo." Considera então a concatenação e a simultaneidade $^{206}$ no trabalho da dramaturgia, que para ele é tomada como a tessitura das ações no espetáculo, o texto aí envolvido, na formulação da trama (BARBA \& SAVARESE, 2012, p. 66). Watson (1993, p. 95) destaca a preferência de Barba pela simultaneidade diante das possibilidades de perspectiva multifacetada que esta traz à dramaturgia. Nessa opção, Barba (BARBA \& SAVARESE, 2012, p. 67) acredita que uma maior complexidade possa brotar, derivados do entrelaçamento de várias ações dramáticas, cada uma dotada de seu próprio "significado", em uma única unidade de tempo, provendo a cada fragmento de "multiplicidade de facetas", ganhando um aspecto tridimensional que faz com que o presente do acontecimento se destaque da necessidade de linearidade pelo entendimento de uma concatenação à sucessão temporal de acontecimentos. Essa perspectiva, como nota o diretor, traz ao espectador a necessidade de "viver uma experiência", pois é difícil avaliar ou

\footnotetext{
Disponível em: <http://michaelis.uol.com.br/moderno/portugues/index.php?lingua=portuguesportugues\&palavra=sinestesia $>$. Consulta: 28/08/2014.

205 Tradução nossa do programa da peça em espanhol (Trad. Anna Wolf). Original: "Me han dicho frecuentemente que mis espectáculos no son muy comprensibles.” (2011, p.4).

${ }^{206}$ A primeira "tem a ver com o desenvolvimento das ações no tempo, através da concatenação de causas e efeitos ou através de alternância de ações que representam dois desenvolvimentos paralelos.” (BARBA \& SAVARESE, 2012, p. 66). Esse tipo de formulação da trama está vinculado principalmente na encenação de textos que tem narrativa determinada pela linearidade sucessiva dos acontecimentos. Já a simultaneidade "tem a ver com a presença simultânea de várias ações" (ibidem), e que pode ser identificada em vários espetáculos orientais, como ressalta Barba (op. cit. p. 67).
} 
interpretar prontamente o sentido do que está acontecendo. ${ }^{207}$ É o que chamará de “experiência da experiência”, aproximando as construções dramatúrgicas (em todos os níveis constituintes do espetáculo) das sensações que causarão ao espectador. Diz ele (BARBA, 2010b, p. 59):

\begin{abstract}
O espectador deveria intuir ou captar o sentido da história ou de uma sucessão de ações num espetáculo. Mas, sobretudo, ele deveria viver emotivamente o espetáculo (ou algumas de suas partes) e recordá-lo com as mesmas implicações pessoais e o mesmo grau de ambiguidade com que se vivem, sem um sentido prévio, os acontecimentos da vida cotidiana, tanto os comuns quanto os dramáticos.
\end{abstract}

Para perscrutarmos ainda mais sua forma de trabalhar entre materialidades e criação de sentido, lembramos que, entre os níveis que compõem o espetáculo, Barba também fala da dramaturgia sonora ${ }^{208}$ (2010b, p. 77-80) na qual a voz é tratada como "uma força material" e leva em conta a informação não só em sua possibilidade de comunicação semântica, que compreende o significado das palavras, como valoriza a "comunicação sonora" que, através das entonações e variações no modo de dizer, possibilita um jogo de contrastes entre o significado e a emissão das palavras. Sobre a dramaturgia do espaço ${ }^{209}$ (2010b, p. 84-90) salienta sua procura por diversas utilizações dos locais em que se apresentam, modelando a presença do ator a distintos planos na criação de uma arquitetura que se diferencia nos níveis de relação, que vão de muito próximo, geralmente nos espetáculos indoor, a muito ampliado, em encenações ao ar livre, p. ex., sendo que essas noções são intercambiáveis, ou seja, podese também relacionar-se como em um espaço ampliado em situações de proximidade, mudando a percepção do campo ao qual o ator se dirige. Barba reconhece o "espaço-rio" como o mais frequentemente adotado nas encenações do grupo. Trata-se de dispor os espectadores nas "margens" enquanto o fluxo do espetáculo se passa no meio, com ações simultâneas de igual importância em diversos pontos. Essa disposição força os espectadores a escolherem para onde vão olhar e eventualmente ficarem face-a-face com outro espectador sentado diante de seu campo de visão. Implica em um processo de seleção que conduz a uma

\footnotetext{
207 Em um exemplo prático desse pensamento aplicado ao trabalho do ator, Barba pediu que os atores se levantassem apenas poucos centímetros das cadeiras. A partir daí, explica, esse impulso visto pelo espectador leva à expectativa da sucessão da ação, ou seja, ficar em pé. Mas, é exatamente nesse momento que podemos escolher outra direção, ou parar a ação, mudando seu ritmo, enfim, transformar a experiência óbvia em surpresa, mudando a percepção do espectador entre o que já adivinhava como sequência para atenção ao que virá, uma vez que não correspondeu ao que ele esperava. Anotação pessoa A Arte secreta do Ator - Brasil, Brasília, $09 / 12 / 2011$.

208 A música e orquestração de sons também é um fator importante nas encenações do grupo. Cf. BARBA, 2010b, p. 80-83.

${ }^{209}$ Cf. BARBA \& SAVARESE, 2012, p.68-71 e BARBA, 2010b, p. 84-90.
} 
dramaturgia do espectador, que pode ser diferente da montagem do diretor, dependendo da ordem que se olha para os acontecimentos e estabelecendo um "sentido" particular entre eles. $^{210}$

Barba (2010b, p. 57-60) chamará de empatia cinestésica àquilo que, visto pelo espectador, produz uma reação física e influencia a atribuição de sentido que fará. A dramaturgia do ator, composta por ações e lógica pessoal de cada um, é organizada pelo diretor em uma dramaturgia orgânica ${ }^{211}$ a fim de "engajar e persuadir os sentidos do espectador." Barba diz que estar em vida é uma sensação que o espectador tem que ter ${ }^{212}$. No trabalho com o ator, por exemplo, procura por "uma dança de estímulos sensoriais que afetassem meu sistema nervoso." (2010b, p. 97). Carreri (2011, p.120) anota que "o ator deve seduzir (do latim seducere, 'conduzir a si') a mente do espectador até fazer com que atinja aquele momento de gratificação que vem de compreender o que [o ator] está 'realmente' fazendo."

E não é o objetivo de qualquer ator cooptar a atenção, fazendo com que cada espectador fique, de certa forma, hipnotizado com sua presença? Também o encenador não se preocupa com os centros de atenção que o ator e/ou a interação cênica vai gerar e servir à sua concepção da obra? Tomo um exemplo de Eugenio Barba, dado em um de seus cursos, parafraseando-o: como obter a atração do olhar que uma aranha no chão exerce, ao rodear a cama em que estamos? $?^{213}$

${ }^{210}$ Assisti a A Vida Crônica por quatro vezes. Uma durante a Odin Week, (ago/2013), duas em São Paulo, SESC Belenzinho (nov/2013) e uma no Festuge, (jun/2014), sempre sentada em locais diferentes. A experiência me proporcionou ainda mais conscientemente a escolha do que seguiria nas muitas ações simultâneas da peça. Esse é um espetáculo que considero particularmente caótico e no qual Barba reduziu ainda mais o espaço do meio, montando uma espécie de balsa (SCHINO, 2014, p. 35) em que vagueiam as personagens aparentemente desconexas, cada qual perseguindo sua obsessão. Tentando me distanciar do olhar especializado, recusei-me a ler o programa nas duas primeiras vezes, para criar minha própria versão sobre “o quê" estavam falando. Quando finalmente li o programa, "entendi que tinha entendido" a peça, porém com interpretações que eram particulares, na configuração de minha montagem pessoal como espectadora. Mas a experiência se superpõe ao sentido, deixando claro que o que fica são as sensações produzidas pelo espetáculo e não "a mensagem". São as sensações que nos fazem arrepiar com lembranças, evidenciando a fisicalidade das vivências.

${ }^{211}$ O diretor (BARBA, 2011, p. 40) ainda isola mais dois níveis: a dramaturgia narrativa, ou seja, a orientação que a trama fornece aos espectadores sobre o sentido (ou sentidos) do espetáculo; e a dramaturgia evocativa, nível que não pode ser programado conscientemente, mas que tem a capacidade, quando atingido, de causar ressonâncias e significados íntimos para cada espectador.

${ }^{212}$ Anotação pessoal. A Arte Secreta do Ator - Brasil, Brasília, 09/12/2011.

${ }^{213}$ Anotação pessoal. A Arte Secreta do Ator - Brasil, Brasília, 09/12/2009. 


\subsection{Presença cênica}

Em todas as tradições pessoais, os atores do Odin Teatret ressaltam que o trabalho efetuado visa à conquista da presença cênica na relação com os espectadores; relação real, no "aqui e agora" do acontecimento, na qual o olhar do outro deve ser despertado.

Em Pavis (2008, p. 305), encontramos a definição de presença como um "saber cativar a atenção do público e impor-se; é, também, ser dotado de um 'que' que provoca imediatamente a identificação do espectador, dando-lhe a impressão de viver em outro lugar, num eterno presente.”. Essa definição é vaga, como salienta o próprio Pavis (2008, p. 305306), ao ressaltar como um "mistério inexplicável para os teóricos" a tentativa de explicação de uma "energia irradiante", que se dá em um campo de mistério da arte do ator. O autor propõe, então, uma aproximação semiológica, ou seja, do sistema significante do fenômeno como acontecimento colidido entre jogo e ficção, produzindo uma identificação do espectador, que pode ser de estranhamento ou familiaridade, com o corpo presente do ator, gerando uma espécie de fascínio.

A "presença cênica" é discutida com Barba durante uma sessão do Meeting with Eugenio, na Odin Week de 2013. ${ }^{214}$ Após admitir certa dificuldade em defini-la, ele fala sobre uma percepção (feeling) de se estar lá e comunicar algo importante, porém, sem pensar que aquilo que esteja falando seja importante. Nota que não é só uma narrativa, uma forma de dizer algo, mas uma atitude corporal, como ele exemplifica ao evidenciar a prontidão de seu corpo, muscularmente engajado, prestes a se levantar da cadeira, enquanto faz considerações sobre o tema. Salienta as seguintes sensações corporais enquanto realiza as formulações concomitantes à sua demonstração física do estar presente: "energia, eletricidade, química, impressões, ideias estranhas". Diz: "Estar presente significa ser capaz de atrair e manter a atenção do espectador; e o ator saber como compor sua dramaturgia. [...] Reorientar a atenção do espectador, a sua percepção." ${ }^{215}$ Varley (2010, p. 59), por sua vez, nota que "A presença

\footnotetext{
214 As próximas citações das falas de Barba nesse parágrafo dizem respeito a informações orais passadas no encontro em questão. Trata-se de anotações pessoais em meu diário referentes ao dia 20/08/2013. Odin Week, Holstebro, Dinamarca.

${ }^{215}$ Essa capacidade de prender a atenção faz parte também da figura de Eugenio Barba, não só como diretor, mas como brilhante orador que é. Indiscutivelmente sentimos sua presença, que no caso não é em situação de palco, mas, levando em conta o quanto se expõe, diríamos, sim, que se trata de estar em cena, protagonizando seus próprios pensamentos e formulações. Sem entrar no aspecto da "persona Barba", que consegue a explicitação sobre o controle e o descontrole do acontecimento, identificamos o conhecimento sobre o que fala, a crença profunda arraigada em anos dedicados ao estudo do fazer cênico, e a inquietação motivadora orientando quem trabalha com ele nessa empreitada. Em Queimar a casa, Barba (2010b, p. 215-217), através da transcrição de
} 
cênica é a condição para transformar em ações persuasivas ideias e desejos, para dar à força criativa interior a possibilidade de se revelar e de se transformar em forma comunicativa." Para isso, ela afirma que teve de aprender a "pensar com o corpo", através de exercícios que a tiravam do estado natural do corpo, fortaleciam e desafiavam sua estrutura, permitiam variações de ritmo e constante fluxo, fazendo-a trabalhar também com a noção de emanar a "energia" do corpo para o espaço mesmo quando estava parada. Chamou a isso de "respiração das células" (p. 50) ou "respiração do corpo" (p.60).

Carreri em Traces in the snow, sua demonstração de trabalho, começa a sua fala explicando que como atriz, tem que viver o aqui e agora, com a mente e corpo conectados para ter presença. O treinamento serve para conquistar essa conexão e poder, através do "habitar o instante" estar apto para reagir, sem confundir essa qualidade de presença com uma tensão excessiva (CARRERI, 2011, p. 48). A presença cênica alcançada pelo ator, e que é formada por todos os seus recursos pessoais, pode ser comparada à neve cintilante e macia que cobre a dura escada da técnica (p. 17).

Perguntados nas entrevistas sobre o que é presença cênica, os atores do Odin Teatret formularam:

[...] a condição de vivacidade em seu corpo que é oposto à letargia [...] seu corpo está num sentido de vibração no espaço e isso pode vir de como você se mantém, como cria sua personagem dentro disso, as dinâmicas que cria e o uso de todos os princípios que Eugenio fala. (Donald Kitt, Holstebro, 27/08/2013).

É como e saber tocar e afinar um instrumento, você tem que saber tocar as escalas; [...] você pode improvisar, mas precisa de uma técnica para fazer bem, depois vai seguir a partitura, fazer as ações em seus mínimos detalhes, como mexer a cabeça, como focalizar o olhar, trabalhar as oposições, abaixar um pouco as costas [demonstra pequenas ações enquanto fala]. E tudo isso vem do treinamento, que você consegue ter consciência desta presença do corpo todo, pés, braços, mãos, tudo. (Jan Ferslev, São Paulo, 29/10/2013).

Para mim, presença cênica é construir todo o tempo uma rede de motivações. O que eu chamo de subtexto. Uma rede de motivações que me faz reagir, que me faz sentir viva no palco. Por exemplo, para chegar nessa presença cênica, o treinamento, claro, te serve, mas o momento do espetáculo não é o do treinamento. Eu acredito que às vezes chego a ter presença cênica, às vezes menos. Quando chego a ter mais, é porque tenho uma rede de motivações internas que me fazem estar como num filme, um filme interior, no que estou ali e jogo. [...] Presença cênica pra mim é de dentro, pelo menos como atriz, como espectadora talvez não seja a mesma coisa. Como atriz é quando jogo e tenho um motivo, quando tem uma história por trás. (Sofia Monsalve, São Paulo, 03/11/2013).

um diretor presente na ISTA de 1980, fala do "poder do diretor" e do quanto este também tem que ter desenvolvido em si os princípios de modulação de energia que regem o trabalho do ator. 
Presença cênica é quando você está criando um tipo de atmosfera magnética. Stanislavski fala em círculos de atenção. Você tem que contrabalançar suas tensões e estados de relaxamento, e isso, de alguma forma, causa uma impressão sobre os espectadores e também sobre os outros atores. Você está aterrado, tem um bom contato com o chão de forma que transmita abertura, que seus olhos estejam abertos em diferentes direções, e, basicamente, estar sempre atento à relação com os espectadores. Estar aberto a eles. Isso não quer dizer olhar para eles o tempo todo, mas p. ex, quando você está de costas, precisa manter essa [intenção de] abertura. (Tage Larsen, 26/08/2013).

A presença cênica, claro, requer ter precisão, estar no ritmo certo, mas também tem que ter vida, tem que produzir vida. Se você está viva em cena, você não é automática [...] Quando trabalho como diretora eu tenho que olhar e sentir algo em meu estômago, então eu sei que está certo. (Else Marie Laukvik, 25/08/2013).

Eu acho que é saber exatamente o que você está fazendo e ao mesmo tempo fazer algo menor, a fim de tentar confundir seu corpo com alguns obstáculos. (Kai Bredholt, 03/11/2013).

Eu penso que pode ser duas coisas: uma que você aprende com a técnica, quando desenvolve uma espécie de aproximação com a audiência baseado em técnicas de movimentos, uso da voz, da música, mas também existem pessoas que tem uma presença cênica natural. Isso quer dizer que você pode ter que dar uma longa caminhada para conquistá-la ou, se tiver sorte, poder ter um talento natural. (Frans Winther, 24/08/2013).

Como podemos ver, as definições variam e muitas vezes continuam no terreno do impreciso, como alertado por Pavis no início deste tópico. Porém, podemos nos agarrar aos aspectos tangíveis das percepções sobre a presença cênica, salientados na sua construção através do corpo treinado, das ações, do uso dos princípios, da precisão do corpo no espaço, enfim os aspectos da materialidade, sem esquecer de que a interioridade de cada ator é que colorirá a sua presença, emanando-a em cena. Diz Barba (2010, p. 30),

É evidente que não basta apenas a ação orgânica. Se ao final a ação não aparece habitada por uma dimensão interior, torna-se vazia e o ator aparece preestabelecido pela forma de sua partitura. Não creio que exista apenas um modo de fazer brotar a interioridade. Creio que o método seja de negação: não impedir que a interioridade se desenvolva.

Nessa passagem entre o visível e o invisível, o ator deve estar com seu corpo-em-vida, permitindo que toda a sua preparação para a cena seja atualizada no momento presente em que nela esteja. Para o ator, as tensões produzidas entre materialidade e sentido, presença e ausência podem ser decupadas em uma técnica que implica naquilo que o diretor chama de "a arte secreta do ator", na qual um constante jogo de tonicidades musculares associado a oposições, ocultar e mostrar, conter e soltar, mudanças de ritmo, de nível, de direção, entre outros procedimentos de construção da ação física e vocal, vão conduzir à modulação da 
energia de forma técnica (e oculta ao espectador) na criação de ações que visam à organicidade e a produção de associações possíveis por quem as vê. Ao ator cabe a capacidade de defender o impulso inicial da ação e, imperceptivelmente, preparar a próxima. Manter a transparência do impulso na conformação de uma dramaturgia orgânica ou dinâmica, que diz respeito aos aspectos básicos da composição de seu trabalho (BARBA, 2010b, p. 39) e, com a sabedoria da técnica para manipular a expectativa do espectador, inscrever sua presença no tempo e no espaço.

\subsubsection{A aquisição técnica da presença}

A abordagem técnica para aquisição da presença pode ser localizada em suas raízes já em Stanislavski (2003, p. 319-321), que, durante a elaboração de seu Sistema, ao falar da atitude cênica interna atingida por meio de uma psicotécnica, aponta o início da tarefa do ator pela consciência da relação muscular em consequência à ação a ser realizada. E, avançando na conformação daquele, chegará ao método de ações físicas esclarecendo ao ator a possibilidade de eleger e ordenar as circunstâncias propostas naquilo que o motiva agir, reconhecendo seu caráter criativo em uma abordagem psicofísica, na qual a subjetividade encontra-se unida à materialidade. A aplicação do treinamento físico, derivado de técnicas diversas para contribuir com a excelência do ofício, é apontada por Stanislavski em sua sistematização ao recomendar práticas corporais como preparação pré-cena, a fim de buscar um corpo livre de tensões, com domínio de toda a sua estrutura visando "dar forma externa aos sentimentos invisíveis" (STANISLAVSKI, 1997, p.182). Como treino expressivo para o corpo do ator sugerirá “[...] ginástica, dança, acrobacia [...] esgrima, [...] todos os aspectos do treino físico." (STANISLAVSKI, 1997, p. 199). O objetivo dos exercícios é de tornar a "aparelhagem física mais móvel, flexível, expressiva e até mais sensível.”, enquanto a dança é capaz de produzir "fluência, amplitude, cadência no gesto" (STANISLAVSKI, 1989a, p. 61; 67). Porém, há a preocupação com que os corpos não desenvolvam demasiada musculatura, o que poderia engessar os movimentos, e, também, se evitar qualquer "afetação" surgida a partir dos movimentos de braços e mãos do ballet, por exemplo. O trabalho corporal, para Stanislavski, deve servir à capacidade do ator de encadear, com organicidade em cena, as ações físicas da personagem, que denotarão suas motivações e vida interna. E esse encadeamento se dá coordenado com o tempo e o ritmo da ação estabelecendo uma "corrente interior de energia" (1989b, p.83) e precisa ser passível de uma "repetição dinâmica, que se preenche e justifica 
progressivamente" (BONFITTO, 2006, p.36. Itálico do autor). Dirá Stanislavski (1989, p. 309) que, para trazer ao palco a vida, o ator é obrigado a praticar exercícios sistematicamente e treinar com paciência e fé, sem desanimar.

Grotowski, por sua vez, em sua investigação do fazer teatral conduziu o corpo do ator em uma vertente de aprimoramento extremo das capacidades físicas, através de exercícios chamados plásticos e acrobáticos, além de desenvolver uma técnica de ressonadores para a voz. O corpo é também o meio e veículo para alcançar um estado de entrega total, um corpomemória, disponível ao personagem mediante uma vida interna, localizada em um centro irradiador que é físico, o cóccix, e emanado de dentro para fora a fim de produzir uma energia que atinja os espectadores (GROTOVSKI, 2010, p. 172). Os exercícios servirão de estrutura para a manifestação de uma espontaneidade, que visa o corpo-vida, a manifestação de uma energia pulsante e atualizada em cena. Grotowski (2010, p. 163) afirma que o tipo de exercício que o ator deve eleger depende de sua relação criativa com o teatro, uma vez que os exercícios por si só não desenvolvem os impulsos físicos do corpo. O ator como poeta, segundo ele (GROTOVSKI , 2011, p. 27), pode construir sua própria linguagem, revelando os impulsos escondidos exprimidos em sons e gestos que estão no limiar do sonho e da realidade. Fala (2010, p. 170), ainda, do percurso de aquisição do domínio do gesto, mas ironicamente ressalta que a repetição dos chamados exercícios plásticos podem, no máximo, gerar uma perigosa desconexão entre o corpo e os gestos. Salienta que, se os gestos não brotam do interior do corpo, serão falsos. A especialização do corpo por si só não serve ao ator, pois um corpo muito especializado traz consigo o ônus das técnicas, dado ressaltado desde Stanislavski e reafirmado por Grotowski, quando reconhece corpos aprisionados pela técnica, domesticados em qualidades de movimento, que não os permitem ser pessoais. Apesar de todas as práticas serem bem vindas, desde que não cristalizem padrões musculares de respostas. A preparação corporal deve servir, portanto, para liberar o ator na direção de ser “irradiante” em cena (GROTOVSKI, 2010:170). Questiona (2010, p. 171) a mera cópia de técnicas como dançar um tipo específico de coreografia e ter capacidade de alguns elementos da pantomima, e adverte sobre o uso de "receitas" para se alcançar um resultado estético. Pergunta: "Onde está o trabalho do ator? Onde está sua criação? Onde está a linha de impulsos vivos, que tornam o ator irradiante?” (2010, p. 169). Grotowski (2010, p. 179) alerta, em uma de suas paradoxais formulações:

A presença da técnica não é o mesmo que a presença do Ato. A técnica pode ser (em graus diversos) um sintoma de um Ato sub-rogado. Se executarmos o Ato, a técnica surge por si mesma. A técnica fria, consciente, serve para evitar o Ato, para nos 
esconder, para nos cobrir. A técnica emerge da realização, portanto a falta de técnica é um sintoma da falta de honestidade. Existem só as experiências, não o seu aperfeiçoamento. A realização é hic et nunc (aqui e agora). Se existe a realização ela nos conduz ao testemunho porque foi real, plena, sem defesas, sem hesitação...

Ainda perseguindo as pegadas dos mestres em sua relação à aquisição de presença, Meyerhold, o Judas Iscariote (Jimenez, 1990) do sistema stanislavskiano, vai propor uma desnaturalização da cena, e uma disciplina estética de gestos estilizados oriundos de um estudo detalhado do corpo e sua expressão. A fim de ressaltar ainda mais a construção da cena, o cenário assumirá formas geométricas, os deslocamentos respeitarão um ritmo, e os gestos serão precisos e marcados, produzindo uma realidade icônica. Aqui, a mão do encenador pesará, ou melhor, sustentará os fios que promovem uma encenação, articulando tudo, como titeriteiro, manipulador de fios invisíveis que comporão a cena em todos os seus aspectos. A invenção de uma técnica de segmentação corporal e extrema consciência de movimentos é por ele chamada de Biomecânica ${ }^{216}$, e tem por objetivo propiciar ao ator o total domínio corporal. Esse domínio está a serviço de uma materialidade ligada à concepção da obra na produção de um resultado estético através do controle absoluto do corpo do ator. ${ }^{217}$

Barba (\& SAVARESE, 2012, p. 276) fala das técnicas extracotidianas servindo ao ator para o desenvolvimento de uma presença cênica que antecede a expressão. Em seu pressuposto de "aprender a aprender", a técnica no percurso de aquisição do domínio cênico do ator pode ser inicialmente meramente cópia de exercícios aprendidos. "É natural que uma pessoa comece repetindo algo que não é seu, que não pertence à sua história, que não deriva de sua investigação.” (BARBA \& SAVARESE, 2012, p. 290). No entanto, é desejada que a influência do mestre ou da técnica permita o amadurecimento da prática, que conduzirá o ator à personalização e à sua própria técnica.

\footnotetext{
${ }^{216} \mathrm{O}$ nome da técnica contém em seu significado uma busca científica do entendimento de vida no movimento, sendo bios=vida, mecânica=estudo do movimento (Fís). (BARBA e SAVARESE, 2012, p. 206).

${ }^{217}$ O conceito "meneur de jeu" (Pavis, 2007, p. 128), ou seja, condutor do jogo cênico serve bem ao caso, no qual o ator estava a serviço de uma visão do diretor. Esses corpos manipuláveis em Meyerhold salientam ainda mais a presença em seu aspecto de materialidade e do dar-se a ver. Ao mesmo tempo, esses corpos à mercê, estão também conferidos de ausência, do retirar-se implícito nas dimensões de presença, uma vez que não manifestam uma vida orgânica, mas antes, a estilização da vida, gerando uma empatia pelo estranhamento e repletos de uma intencionalidade que se oferece a uma encenação concebida em sua materialidade como um todo equiparado em importância entre ator, cenário, gestos, elementos e sonoridades, em composições de encenadores que querem dar a ver alguma coisa; uma ideologia que se quer explicitada para o público, um teatro de convenção, no qual a vida torna-se mais real justamente por ser inverossímil.
} 
Penso que a aquisição de uma técnica pode ser comparada à da linguagem. Quando bebês, começamos a compreender a língua natal e a decodificar em seu nível básico. Mais tarde, com o aparelho fonador também treinado, tornamo-nos capazes de, além de entender, codificar a linguagem para produzirmos formulações. Posto sem esquecer que estaremos baseados ainda em nosso manejo das possibilidades linguísticas, que não deixam de ter influências do meio em que vivemos e dos interesses que desenvolvemos. Nessa codificação estaria a assimilação da técnica para o ator como pessoal e não mais simplesmente uma cópia daquilo que é feito por outros. E o ator tem que sempre ser desafiado a falar outras línguas e dominar outros tipos de codificações.

\subsubsection{O que é o treinamento e para o que serve?}

Tomamos como premissas: 1. O treinamento é fundamental para o ator, a fim de descobrir e lapidar suas próprias capacidades. 2. No Odin Teatret cada um desenvolveu o seu treinamento baseado em princípios decodificados e que levam à presença cênica.

A passagem dessa tradição visa munir o ator de "pontos de partida" para que, a partir de exercícios, a ressignificação de sua execução faça sentido em cada corpo.

A palavra treinamento no aspecto semântico abarca acepções de adestramento, capacitação, está ligada à destreza e ao conhecimento adquirido. Varley (2010, p.77) a associa, entre outras, à preparação, meditação ativa, refúgio, competição consigo e outros, perguntando-se ainda se não seria um pouco disso tudo. Carreri (2011, p. 124) o chamará de “jardim secreto do ator" como "o lugar onde pode cultivar seus sonhos e suas nostalgias profissionais, explorar tudo aquilo que para ele é importante e não acha espaço nos espetáculos do grupo."

O treinamento, como aponta Bonfitto (2012, p. 74), passou a ser um mito lançado por Grotowski - apesar de todas as considerações que este faz a seu respeito, como o uso dos exercícios, que já comentamos no tópico acima - ganhando status de solução para a encenação. Mas tomado como referência de caminho a ser seguido, ou segundo Grotowski (2006, p.33), "a descoberta de um caminho por onde começar." (2011, p. 13), pode levar o ator àquela condição de autoconhecimento e acesso às fontes. Na experiência desse diretor, o treinamento nasceu para que fossem resolvidos problemas práticos dos atores durante a 
montagem de Akropolis, mas se desenvolveu e se tornou "uma atividade autônoma do ator, não relacionada necessariamente ao trabalho no espetáculo" (GROTOWSKI, 2006, p.51).

Barba conta, no dia 11 de dezembro de 2009, que o treinamento desenvolvido por cada ator no Odin Teatret gerou uma maneira particular de pensar. Inicialmente, ou seja, há cinquenta anos atrás, copiaram e criaram exercícios, trabalharam em câmera lenta, buscaram inspiração em animais como a pantera, para chegar ao entendimento da imobilidade ativa, aquele estado de atenção que antecede o ataque, por exemplo. Acrescenta que no início do grupo, e como princípio, a ênfase estava no fazer: fazer exercícios, escrever sobre o que se fez; repetir, repetir e repetir. Inclusive os erros. ${ }^{218}$ Questionavam-se, como inventar? Sair da moldura fixa da repetição e chegar sempre à ação original? Depois, entravam em diálogo físico com o partner ou com uma música; pesquisaram, ainda, as qualidades orgânicas, rítmicas, o dilatar e concentrar ações. ${ }^{219}$

O treinamento físico e a criação de exercícios buscam o domínio dos princípios no corpo. Segundo Barba, a disciplina técnica alcançada pelo treinamento passou a ser uma necessidade para que o ator alcançasse "sua flora e sua fauna interiores" para chegar ao "território comum da imaginação coletiva", perseguida por Grotowski (2006, p. 33). Os exercícios, decupados em seus objetivos, estabelecem deveres ao corpo-mente do ator, tornando possível trabalhar elementos um a um e se apropriar de um modo de agir. Como diz Barba (2010a, p. 103),

Os exercícios são pequenos labirintos, que podem ser percorridos mais de uma vez pelo corpo-mente do ator para que ele incorpore um modo de pensar paradoxal, para que se distancie de suas ações cotidianas e se desloque para o campo das ações extracotidianas da cena.

Ao longo dos anos, o treinamento dos atores do Odin Teatret sofreram mudanças assim como o testemunhado por Barba junto a Grotowski. O mestre polonês acusou as diferenças na evolução dessa noção em seu trabalho, em uma carta à Barba (2006, p. 158):

\footnotetext{
Agora nós também utilizamos o princípio de ligar os exercícios entre eles através de um fio de improvisação contínua. Desta maneira obtenho horas de treinamento nas quais as correntes de associações individuais mudam todos os dias, e onde são eliminados todos os elementos de ginástica (aqueles que correm o risco de cair num perfeccionismo a partir de uma repetição mecânica).

${ }^{218}$ Sobre eles, cf. BARBA, 2010b, p.52.

219 Anotação pessoal. A Arte Secreta do Ator - Brasil, Brasília, 11/12/2009. Barba trata deste assunto nos capítulos O treinamento e Palavras ou presença do livro Teatro - Solidão, Ofício, Revolta (2010a, p. 76 e 87).
} 
Procurando o fio, poderíamos dizer que o treinamento é primeiramente a eleição que o ator faz de estratégias físicas e vocais, nomeadas como exercícios, na preparação do seu corpo para desenvolver sua potencialidade de presença em cena. É mutável em sua repetibilidade conforme o ator avança em sua execução. É a preparação de um corpo pronto para a ação e uma mente presente, apta ao fazer do momento. É através do treinamento que o corpo se torna decidido, ou seja, tem em si, o conhecimento ${ }^{220}$ capaz de prover-lhe uma gama ampla de escolhas entre o que já foi assimilado através dos exercícios.

E para o que isso serve ao ator? Segundo Grotowski, para atingir um conhecimento profundo do corpo e seus poderes - que são diferentes e pessoais - e para dar-lhe liberdade em cena. Um corpo-resposta, um corpo ativo e reativo consciente de tensões e relaxamentos, consciente das ondas de "contrações e distensões" que seguem seu rumo como um rio (2010, p. 168), e que pode vivificar-se, ter o frescor do aqui e agora em sua presença e ações. Dirá Grotowski (2011, p. 29): "Nenhum exercício dos vários campos de treinamento do ator deve ser exercício de habilidade. Eles devem desenvolver um sistema de alusões que levem ao ilusório e indescritível processo de autodoação."

Porém entendemos que o treinamento supõe sim o desenvolvimento de habilidades específicas como a capacidade de resposta/reação, a desenvoltura física, a escuta especializada, o conhecimento e controle da respiração e qualidade da emissão da voz, entre outras. Mas a habilidade específica primordial de um ator é não ser escravo de suas habilidades físicas especializadas em alguma técnica (acrobacia, dança, mímica ou outras) apesar de seu corpo ser dotado de técnica para atender à produção de materiais e sua aplicação que o coloquem presente em cena.

A habilidade desenvolvida pelo treinamento físico não deve estagnar-se, mas sim estabelecer pontes entre o físico e o mental criando um fluxo de estímulos que são atualizados a cada (re)fazer. Diz Barba (2012, p. 57):

\begin{abstract}
Os exercícios do treinamento físico permitem desenvolver um novo comportamento, um modo diferente de se mover, de agir e reagir: uma certa habilidade. Mas essa habilidade fica estagnada numa realidade unidimensional se não toca em profundidade, se não penetra no profundo de uma pessoa, aquele lugar que constituído por seus processos mentais, sua esfera psíquica, seu sistema nervoso. A ponte entre o físico e o mental determina uma leve mudança de consciência que permite superar a inércia, a monotonia da repetição.
\end{abstract}

\footnotetext{
${ }^{220}$ Savarese (apud BARBA \& SAVARESE, 2012, p. 296) faz essa relação com os exercícios acrobáticos, que possibilitam ao ator enfrentar seus medos, superar limites e ter controle sobre os movimentos.
} 
Richard Schechner (apud BARBA \& SAVARESE, 2012, p. 291, 292) aponta cinco funções para as quais serve o treinamento, notando que elas podem se sobrepor. A primeira é à interpretação de textos, tomando o ator como o transmissor dos mesmos. Associa à segunda função do treinamento a modelação do ator ao que chama de performances texts, como os espetáculos do Nô, no quais predominam os componentes não verbais. A terceira função reside em preservar um conhecimento secreto, passado de geração em geração, que contém em si perigo e poder. Schechner identifica nessa função principalmente as técnicas orientais de representação em que o saber é transmitido para escolhidos e o papel do xamã, detentor de um saber secreto. Ajudar na conquista da expressão pessoal é a quarta função do treinamento, manifestada nos trabalhos de Stanislavski e Grotowski, por exemplo. E a quinta função é a formação de grupos, que desenvolvem forte vínculo, com uma figura forte como "pai ou mãe" e "se baseiam numa fidelidade absoluta à cultura que expressam." Podemos dizer que é nesta última que se encaixa o Odin Teatret.

Integrantes dessa cultura, duas atrizes do Odin Teatret, manifestam suas noções sobre o que é e para que serve o treinamento:

Laukvik : O treinamento é fundamental para o ator. Experimentei por mim mesma quando eu saí em dois [períodos] sabáticos, nos quais eu não fiz nenhum treinamento e, no regresso, tive que começar do zero. Aí você percebe que perdeu a o seu training. É como o músico que não toca seu violino, que perdeu a habilidade, ainda que seja sempre interessante reiniciar o treinamento e sentir, mesmo não esteja bem tecnicamente, porque o training é mais do que apenas ser bom na técnica, é uma experiência com o instrumento em outro nível, nas possibilidades técnicas, mas também é algo mais. É como um poço, que está cheio de potencialidades, que lhe diz para aprofundar seu material, cavar seu material. São todas as possibilidades escondidas, os segredos. É um ponto criativo, um ato criativo. Se a pessoa não lançar essas possibilidades. ${ }^{221}$

Carreri: [...] o treinamento não como ginástica, não como virtuosismo, mas como o enfrentar-se com tarefas que são um desafio para si mesmo no universo físico e mental, dessa maneira você testa cada dia a sua necessidade. É preciso verdadeiramente fazer isso, como um enamoramento de si mesmo. (Entrevista, 23/01/2013).

\footnotetext{
${ }^{221}$ Tradução nossa. Original: "El training es básico para el actor. Lo he experimentado por mi mesma cuando dos veces he tomado sabáticos, en los cuales no he hecho ningún entrenamiento y regresso, y tengo que empezar en cero. Ahí te da cuenta que has perdido su training. Es como el músico que no ejecuta su violín, que pierde destreza, aunque siempre es interessante recomenzar el entrenamiento y sentir, incluso si uno no está bien técnicamente, porque el training es algo más que ser bueno en la técnica, es una experiencia con el instrumento en otro nivel, en las possibilidades técnicas, pero también es algo más. Es como un pozo, le dice a uno que está lleno de potencialidades, que profundice en su material, cave su material. Son todas las possibilidades escondidas, los secretos. Es un punto creativo, un acto creativo. Si uno no se lanza no alcanza esas possibilidades." Conjunto Revista de Teatro Latinoamericano. Casa das Américas. N.108. Enero-Marzo de 1998. La Habana, Cuba. Entrevista a Omar Valiño. p. 30.
} 
Carreri (2011, p. 183) acrescenta que a "finalidade do treinamento é ajudar o ator a ter credibilidade em cena, realizando ações de maneira real e não mecânica [...] habitando a cena, modulando-a, fraseando, desfrutando." Com prazer.

Hoje em dia os atores do Odin Teatret não treinam mais. Mas reconhecem a importância de tudo o que fizeram para a disponibilidade atual. A idade e os muitos compromissos os levaram a outras construções, substitutas dos "exercícios" iniciais. Entre elas, as demonstrações de trabalho e a aplicação pedagógica de seus conhecimentos, que faz com que constantemente revisitem as estratégias para poder ensiná-las, além dos próprios espetáculos que diariamente os desafiam a quebrar os próprios clichês. $\mathrm{O}$ treinamento continua, portanto, mas de outro jeito.

\title{
2.3 Consciência corporal: contribuições para o corpo-em-vida do ator
}

\author{
Meu corpo, minha dor, \\ Meu prazer e transcendência, \\ És afinal meu ser inteiro e único. \\ Carlos Drummond de Andrade
}

Como estudiosa das práticas corporais, ${ }^{222}$ os estudos somáticos sempre me interessaram. Posso dizer que a primeira vez que consegui alinhar meus joelhos, por meio de indicações da rotação coxofemoral, abordada durante o curso da técnica Klauss Vianna, aconteceu uma revolução no meu corpo. Influenciada pela forma que se trabalhava o reconhecimento dos ossos nessa técnica, aprecio até hoje levar para as aulas um esqueleto sintético, auxiliar, junto aos alunos, para o entendimento das rotações dos ossos, seus encaixes e detalhes articulares. Da mesma forma, outras percepções me foram abertas por outras técnicas que vivenciei e são importantes nas aulas que ministro, permeando os exercícios aplicados, por exemplo.

Afinal, contamos com muitos estudos desenvolvidos no século XX que agregaram conhecimento às noções corporais de atores e bailarinos. ${ }^{223}$ No panorama das técnicas, a partir

\footnotetext{
222 Entre técnicas praticadas estão Klauss Vianna, Feldenkrais, Técnica de Alexander, Pilates, além de uma especialização em Dança e Consciência Corporal (FMU-SP, 2008).

${ }^{223}$ Como as desenvolvidas por François Delsarte (1811-1871), Émile JaquesDalcroze (1865-1913), Rudolf von Laban (1879-1958), Meyerhold (1894-1940) (Azevedo, 2008, p. 7-15, 26,53).
} 
da década de 1930, as pesquisas de Matthias Alexander (1869 - 1955), Irmgard Bartenieff (1900 - 1981), Moshe Feldenkrais (1904 - 1984), Gerda Alexander (1908 - 1994), Alexander Lowen (1910 - 2008) (AZEVEDO, 2008, p. 98; 106; 109; 111), o já citado Klauss Vianna (1928 - 1992), entre outros, culminaram em abordagens somáticas também aproveitadas na busca do corpo expressivo do intérprete e na sua sensibilização, envolvendo uma maior consciência de como sua estrutura se move, como guarda tensões desnecessárias e acumula distorções mecânicas que podem prejudicá-lo. ${ }^{224}$ Fazem parte da corrente da educação somática, também os métodos de Body-Mind Centering (BMC), Pilates, Gyrotonics, entre outros. Fortin (1999, p. 41) ressalta três aspectos do interesse de dançarinos (e aqui estendemos aos atores) por essas técnicas: "a melhora da técnica, a prevenção e cura de traumas, e o desenvolvimento das capacidades expressivas."

Na prática da aquisição dos princípios pré-expressivos, os exercícios são exigentes. Em uma linha de trabalho que coloca continuamente o corpo em movimento, com muitas repetições, é preciso saber prepará-lo para tanto desgastá-lo menos (adotando posturas e modos de realizar corretos, fortalecendo a musculatura etc.) quanto compensá-lo (praticando alongamentos, relaxamentos após o trabalho intenso). Apontou Jacques Lecoq (1921 - 1999) (apud PAVIS, 2010, p. 235), falando sobre o retorno da ênfase do trabalho físico do ator, nos idos de 1968, que a abordagem de Grotowski provocou uma "ascese física" pela qual "o ator procurou ultrapassar os limites de seu poder, à força da vontade, arriscando-se mesmo a fazerse mal.”. Em Barba e Savarese (2012, p. 20-21) encontramos a narração do encontro de Katsuko Azuma com sua mestra que lhe dizia sobre a verificação da correção de uma posição: "Se não dói, está errada [...] Mas se dói não quer dizer que, necessariamente, esteja certa.", e ressaltam muitos outros exemplos relacionados a essa aproximação com o "desconforto" como sistema de controle para o ator, uma bússola de orientação, adotada por Decroux, Sanjukta Panigrahi, mestres do ballet clássico e outros.

Ora, sabemos que qualquer prática física leva ao desconforto se não estamos acostumados com ela. No entanto, tendo as noções de direção dos ossos, postura e relaxamento, potencialização dos músculos, alongamento, por exemplo, poderemos preservar principalmente as articulações. Para o ator torna-se particularmente interessante esse tipo de conhecimento, devido à grande variedade de práticas físicas, a partir de diferentes técnicas, às

${ }^{224}$ Esta formulação tem base em meu trabalho final para a especialização em Dança e Consciência Corporal cursada na FMU/SP (2008). 
quais poderá se submeter ao longo de sua trajetória. ${ }^{225}$ Aspira-se que tenha conhecimentos sobre o funcionamento mecânico de seu corpo, noção da espacialidade que ocupa e com a qual está em relação. A dor das posturas, por exemplo, pode ser discernida entre muscular e articular. Quando a dor é muscular, o aluno pode trabalhar o músculo com consciência do seu limite, mas sabendo que essa fibra é moldável, pode ser fortalecida e alongada. Já a dor articular indica mau uso da articulação, ou problema prévio, e que também pode gerar a dor muscular, por exigir compensações e adaptações que provocam estresse no músculo.

Partindo do pressuposto de que o ator usa seu corpo como expressão através do movimento decorrente de ações para traduzir intenções, também os aspectos ligados ao "dentro/fora" de si, a camadas do sensível, são exploradas no entendimento empírico de questões que envolvem o pensamento como uma atitude corporificada e não um estágio separado e/ou superior à carne de que é feito. Entender as suas peculiaridades, sabendo que cada corpo é único, ainda ajuda o ator a se apropriar de suas facilidades, identificar as dificuldades, trabalhar sobre seus clichês e constituir o campo, que é o seu próprio corpo, e mais precisamente, ele mesmo, para experimentar outras formas de colocar-se no mundo, expandindo suas possibilidades de inter-relação consigo, com os outros e com o ambiente. ${ }^{226}$

Diz Fortin (1999, p. 44) que ao reconhecer a "interconexão das dimensões corporal, cognitiva, psicológica, social, emotiva e espiritual da pessoa" a educação somática encoraja "a trabalhar no sentido de uma reorganização global de sua experiência”.

O acesso às práticas somáticas, portanto, proporciona ao ator possibilidades de entender como o corpo funciona, como não machucá-lo, além de "abrir espaço" para colocarse em fluxo, entrar em contato com as sensações, emoções e outras dimensões do ser que estão ocultas sob a matéria, contribuindo para o "trabalho sobre si mesmo" em vários níveis.

\footnotetext{
${ }^{225}$ No conteúdo atual do nível de graduação em Artes Cênicas da USP, contamos com a disciplina Poéticas do corpo e da voz - ministrada por Sayonara Pereira e Andreia Nuhr, ambas formadas em dança- que exige do aspirante as "deformações" relacionadas ao corpo extra-cotidiano, em posições do Ballet clássico, por exemplo.

${ }^{226}$ Formulação inspirada nos pressupostos da disciplina de Dança Contemporânea ministrada pelo professor Henrique Schuller, durante a Especialização em Dança e Consciência Corporal (FMU/SP- 2008).
} 


\section{CAPÍTULO III}

\section{TRADIÇÕES DOCUMENTADAS: A PRÁTICA}

A técnica ligada à prática traz, desde os primórdios da vida humana, a possibilidade de avanços em seus campos de aplicação. Ao lascar uma pedra, o homem pré-histórico criou artefatos que lhe permitiram ser mais eficiente em sua caçada. Do mesmo modo, os artífices que se debruçaram no aprimoramento de suas técnicas foram inventando novos instrumentos e procedimentos para o exercício de suas profissões. No caso do ator, em que a pedra a ser lascada é ele mesmo, os procedimentos técnicos vêm sendo pesquisados e aplicados, primeiramente por atores da Commedia dell arte e depois por pedagogos e encenadores, que sistematizaram suas descobertas. E, como em todos os campos, a técnica é aprimorada pelo fazer. Esse fazer está ligado à imitação, apropriação e treinamento, ou seja, uma rotina de atividades realizadas para alcançar o domínio do que se está fazendo. Está ligado também ao tempo dedicado ao artesanato, em que cada peça a ser criada é única, apesar de ter poder ter um molde inicial ou outro exemplo a seguir. E esse não é o tempo da produtividade em massa, mas da reconstrução e atualização a cada vez que é feito.

O ator, que foi de Stanislavski, de Grotowski, de Meyerhold, que ainda é de Barba. Esse Ator que herda as tradições e teve (e tem) seu corpo submetido a exercícios com objetos imaginários, à dança, esgrima; que teve seu corpo segmentado em ações e expressões. Mexido em seu cóccix, seu ventre, sua mente e espírito, sangue e veias. Manipulado como marionete e que conquistou o domínio acrobático, influenciou seu corpo com outras culturas e buscou, no Oriente, inspirações. Como é transmitida essa herança hoje? E como, a partir dela pode-se configurar o próprio treinamento? $\mathrm{O}$ que funciona e o que não funciona mais? O que já não nos conforta? Carreri nos diz:

[...] o trabalho do ator no treinamento é como o mito de Sísifo, você começa a trabalhar sobre alguns princípios e desenvolver o seu trabalho nesses princípios até que um dia você sabe isso tão bem que vira uma parte da sua natureza e nesse momento, [...] o momento em que você sabe fazer melhor essa coisa, é o momento em que a crise começa, porque isso vira facilmente um automatismo e um clichê. [...] Eu acho que quando uma pessoa vem fazer um curso comigo é para quebrar os seus clichês, para encontra novos caminhos. E quando a pessoa trabalha com esses princípios por muitos anos: "tac", vira um clichê outra vez e precisa encontrar outra direção. ${ }^{227}$

\footnotetext{
${ }^{227}$ Em entrevista concedida a mim, São Paulo, 25/01/2013.
} 
Transmitir uma técnica é abrir possibilidades. Mostrar caminhos, construir pontes. Apesar de Barba (apud TAVIANI, 2014, p. 45) afirmar que "não há uma técnica do Odin" e que nenhum dos atores dirigido por ele pode se considerar como intérprete único e genuíno de suas visões e teorias, as tradições dos atores do Odin Teatret são tomadas como exemplos para se alcançar o domínio sobre os princípios pré-expressivos e conduzir à presença cênica. Não são a única forma, nem a "certa”. Mas serviram aos seus criadores e têm servido a mim.

\subsection{O estado da técnica}

No que se segue, os procedimentos técnicos aprendidos de cada tradição aparecem como foram transmitidos pelos/as ator/atrizes autores dos mesmos em uma replicagem a partir das notas tomadas em campo $^{228}$. Isso não quer dizer que a tradição de cada um se resuma ao que será descrito, mas sim ao que foi documentado e muitas vezes usado por mim na aplicação dos treinamentos vivenciados. ${ }^{229}$ Recorrentemente, veremos orientações e exercícios semelhantes entre as tradições, o que é óbvio, uma vez que os atores são do mesmo grupo e trabalham há tanto tempo juntos. Mas é interessante verificar como, para cada um, os exercícios são aplicados e as orientações transmitidas. Há uma discrepância entre a documentação oferecida sobre as tradições de Varley e Carreri e os outros atores. Isso se deve ao maior aprofundamento, e consequente detalhamento das aplicações adotadas, pela quantidade de vezes em que estive com as referidas atrizes. Porém, abordamos também as outras tradições, apesar de experimentadas apenas uma ou duas vezes, ${ }^{230}$ considerando os registros tomados em campo, a literatura sobre eles e dados em vídeo que pudemos coletar, visando reunir as informações sobre procedimentos dos atores mais antigos em um só documento.

\footnotetext{
${ }^{228}$ Reforçamos a informação comentada na n.r. 24. Muitos dos exercícios aqui citados podem ser vistos aplicados pelos seus criadores em:

<http://new.livestream.com/OdinTeatretLiveStreaming/Odinweek2014>. Consulta em: 20/08/2014.

229 “O pesquisador que participa de um projeto de um artista, que observa durante um longo período de tempo, que escuta e o questiona, não produz uma descrição da realidade, mas principalmente uma construção: a construção de seu reencontro com o projeto de criação.” (FORTIN, 2009, p.82)

${ }^{230}$ No caso de Laudvik, por não ter participado de nenhuma oficina presencial, optei em recolher dados de vídeos e escritos sobre sua prática, além de suas considerações em entrevista concedida durante a Odin Week 2013.
} 
Portanto, aqui se nomeia a transmissão por quem está sendo passada. A descrição dos exercícios procura a fidelidade dos procedimentos como vivenciados, correndo o risco inerente das dúvidas e incompreensões que podem surgir a partir da transmutação de práticas em palavras. E mais ainda, corre-se o risco de descrições distorcidas por um entendimento pessoal daquele exercício. ${ }^{231}$ Tais práticas, que são vivas por estarem sendo realizadas no momento presente da condução dos mestres-criadores, pertencem ao conjunto de informações do corpo e vida de cada um deles. Mas, a coragem nasceu ao perceber que esse é um recurso utilizado muitas vezes na documentação e transmissão das estratégias para o ator, como pelo registro de Barba (apud GROTOWSKI, 2011, p. 96) sobre os exercícios aplicados no Teatro Laboratório de Grotowski, por exemplo. E, pensando em quem e para quem servirão essas documentações, espera-se que, além do registro em si, as tradições deslocadas se organizem no contexto pessoal/corporal de quem tomá-las, quiçá, como pontos de partida concretos; procedimentos para, ao encontrar-se sozinho em uma sala de ensaio, em seu laboratório particular, o ator levantar-se e começar a trabalhar.

Identifico como "premissas corporais" aspectos que servem na execução de todos os exercícios. Eles são oriundos das pesquisas sobre consciência corporal e, segundo experiência pessoal e em aulas ministradas, são facilitadores, além de preventivos no que diz respeito a lesões. São eles:

- Ponto de partida: pés paralelos, separados na distância dos quadris, joelhos em leve flexão, evitando hiperextensão e rigidez das pernas, quadril encaixado.

- Reconhecimento e aplicação dos vetores de direção dos ossos: encaixe dos quadris, direção das espinhas ilíacas, direção dos joelhos, rotação do fêmur, direção das escápulas, fechamento das costelas, conexão cóccix/topo da cabeça, conexão calcanhares/ísquios;

- Reconhecimento da tridimensionalidade do corpo (frente/ lado/costas/topo/base);

- Reconhecimento e uso da resistência do ar em deslocamentos. A imagem que me ajuda e que aplico em aulas é a do ar como uma "gelatina"232 que ainda não endureceu completamente e, variando seu grau de solidez imaginária, dá para se “apoiar".

\footnotetext{
231 Barba, durante A Arte Secreta do Ator - Brasil (08/12/2011, anotação pessoal), fala da comunicação das tradições como "a transmissão da compreensão dos mal-entendidos" e que é justamente isso que muitas vezes nos permite encontrar o próprio caminho.

${ }^{232}$ Não tenho registros de onde veio essa imagem, mas creio que foi de uma aula com Neide Neves, da técnica Klauss Vianna, no final dos anos 1990.
} 
- Consciência de pontos de contatos com o chão.

- Noções de oposição, com o reconhecimento das forças opostas que atuam no corpo para "simplesmente" estamos em pé.

\subsubsection{Tradição Julia Varley}

Sobre a tradição documentada através dos cursos com Varley, encontram-se anotações referentes aos cursos em Brasília (Dezembro de 2009 a 2012), na Dinamarca (Agosto de 2013) e em São Paulo (Dezembro de 2013). Intercruzando as referências das anotações sobre eles, a descrição dos exercícios não segue uma cronologia das aplicações, tampouco é nomeada por Varley com a subdivisão que adotamos, sendo, aquecimento, exercícios com texto e música, exercícios com partituras corporais vocais, formas simplificadas que achamos para organizar os procedimentos. As nomenclaturas dos exercícios em si seguem as usadas por Varley ou, em caso de não haver um nome específico dado por ela (ou que talvez eu não tenha anotado) os nomes atribuídos por mim serão sempre identificados por um asterisco $(*)^{233}$.

Varley irá trabalhar para que atinjamos a capacidade de criar sincronicidade entre o impulso vocal e físico, a fim de proporcionar também uma coerência reconhecível ao espectador. Seus exercícios de voz sempre engajam o corpo todo em movimentos e ações que ajudam o ator a identificar as diferentes tonicidades físicas na produção dos sons/fala. Há também a ênfase em exercícios que conduzam o ator para fora de si, ou seja, que se relacionem com o espaço mantendo a ideia da projeção do que se está fazendo, mesmo na imobilidade (que é sempre ativa). E ela recomenda: "Sigam sua intuição e sorriam, mesmo que por dentro."

Muitos exercícios são realizados em dupla ou grupo e/ou contam com a voz de comando de um ministrante, mas são todos passíveis de adaptação ao treinamento individual. Aliás, essa é uma das chaves do treinamento do ator segundo essa linha: a individuação e descoberta de caminhos que façam sentido para si, na busca do aprimoramento técnico e de lidar com seus próprios desafios.

${ }^{233}$ Assim será também nas tradições seguintes. 


\subsubsection{1 ${ }^{234}$ Aquecimento:}

1. Enraizamento.* Com os joelhos soltos, "escavar" o chão com os dedos dos pés e, em movimentos rápidos e sucessivos, empurrar a planta dos pés contra o chão. Este exercício provoca um balançar do corpo, fazendo os joelhos dobrarem-se e se esticarem, gerando uma cadência. Os braços devem ficar ligeiramente afastados do corpo, com espaço nas axilas. Algumas vezes as mãos também são usadas ao mesmo tempo dos pés, como amassando uma massa.

2. Abraçar o espaço em várias direções.

3. Inspirar pelo nariz, abrindo os braços (como se fosse abraçar uma pessoa que está do outro lado da rua) e soltar o ar em "sh" enquanto fecha os braços ao mesmo tempo (abraçando, sem estrangular) mantendo espaço nas axilas. A inspiração deve ser relaxada e a expiração ativa para permitir a saída do som.

4. Mastigação em "mmm" aventurando-se nas tonalidades.

5. Soltar a voz em "ah" enquanto dobra e estica os joelhos, imaginando um gotejar de água que cai do cóccix, deixando a voz ir para aquela região.

6. Com os braços levantados, soltar a voz em "ah" como um suspiro prazeroso, enquanto baixar os braços (imagem: estar no chuveiro).

7. Com tronco abaixado, produzir som e "mmm" e desenrolar a coluna até ficar ereto e soltar o som relaxando o maxilar.

8. Repetições seguidas e rápidas das consoantes, projetando o som e permitindo sua vibração no espaço: MNÑ; BVZ (como o zumbido de uma abelha) ${ }^{235}$.

9. Trrrr, brrrr, desenhando com a mão e o braço uma espiral ascendente, ou seja, começar o movimento de baixo, com tom grave, para cima deixando o tom subir conforme o movimento; descer do alto, agudo, para o grave, embaixo. Variação: começar o agudo embaixo e subir o movimento indo para o grave, ao chegar no alto. Essa quebra de lógica ajuda a quebrar automatismos. Nesse exercício em todas as variações, deve-se prestar atenção às passagens do tom, percebendo se não damos "pulos" no caminho do som, em todas as suas possíveis transições entre as nuances.

\footnotetext{
${ }^{234}$ Optamos por seguir a divisão em subtópicos, porém os exercícios continuarão em numeração crescente para configurar uma sequência na aplicação.

${ }^{235}$ Varley (2010, p. 52-58) conta que teve problemas com sua voz e, após muitos especialistas, resolveu "seguir sua intuição", desenvolvendo uma abrangente pesquisa sobre a respiração, sonoridades e emissão. Esse exercício está citado na página 57 de seu livro.
} 
10. Com a cabeça apoiada na parede, recolher o som em "mmm" e expelir o som Pá para o centro do espaço. Não há pausa nem mudança de tom entre MMM-PÁ, sendo que a voz deve sair sozinha e não que a lancemos.

11. Luta de "pernacchia" 236 : escolher uma pessoa do grupo que estiver distante e travar com ela uma luta através desse som. Nesse exercício devemos ficar atentos à resistência necessária criada nas costas para que o som chegue do outro lado, e evitar a projeção da cabeça à frente.

12. "Carro cubano" 237 : com a ação de rodar uma dura manivela, como para dar a partida em algo mecânico, emitir "rrrr", permitindo as variações do som conforme o movimento, e em seguida, vogais: a, e, i , o , u, (jogando ao longe a "manivela"). Atentar que vogais devem seguir a trajetória curva do lançamento até seu ponto espacial final.

13. Empurrar e puxar (Push and pull): em duplas, empurrar e puxar o par, trocando de dinâmicas rapidamente;

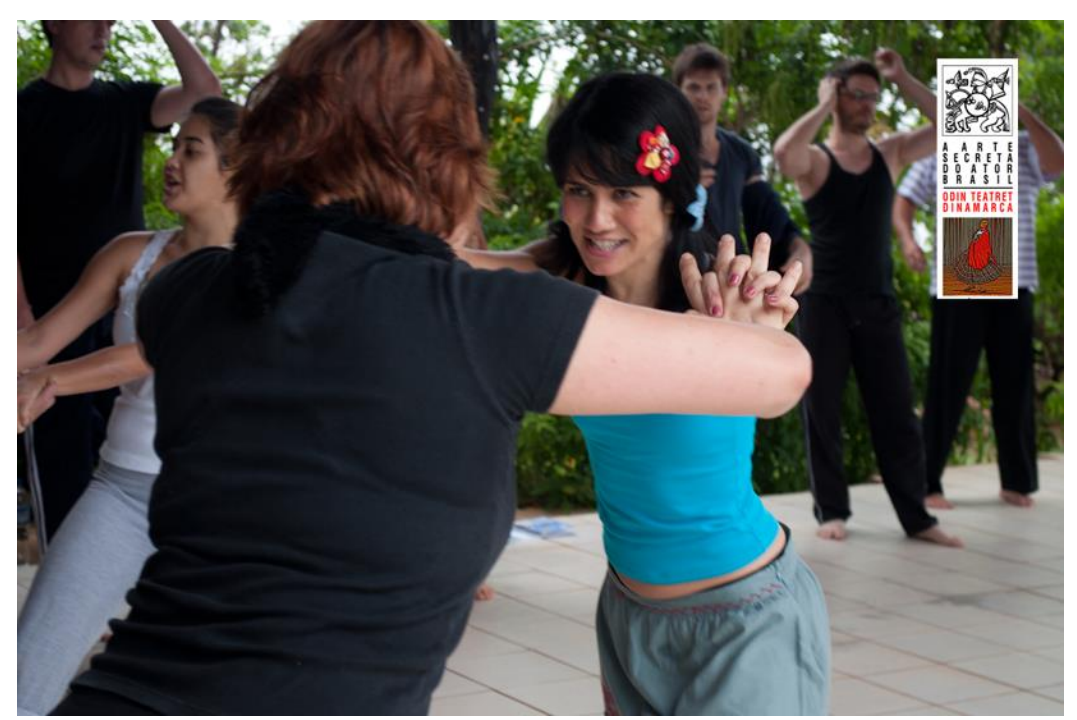

Figura 21. Push and pull - duplas. A arte secreta do ator-Brasil, 2010. Leticia Olivares (de costas) com Luciana Martuchelli. Foto: Edu Barroso.

Depois, individualmente, reproduzir as tensões corporais de força e resistência. (Figura 17) Perceber o dinamismo nos pés em cada situação e cuidar para não fazer mais do que o necessário quando estiver reproduzindo.

\footnotetext{
${ }^{236}$ A "pernacchia" é um termo italiano para um forte sopro emitido através dos lábios cerrados. Disponível em: <http://www.treccani.it/vocabolario/pernacchia/> Acesso em: 04/04/2014.

${ }^{237}$ O nome desse exercício vem de uma experiência de Varley em Cuba com o carro de uma amiga, que pedia emprestada a bateria do vizinho para dar a partida. Anotação pessoal, A Arte Secreta do Ator - Brasil, Brasília, 2009. Cf. também: VARLEY, 2010, p. 266.
} 


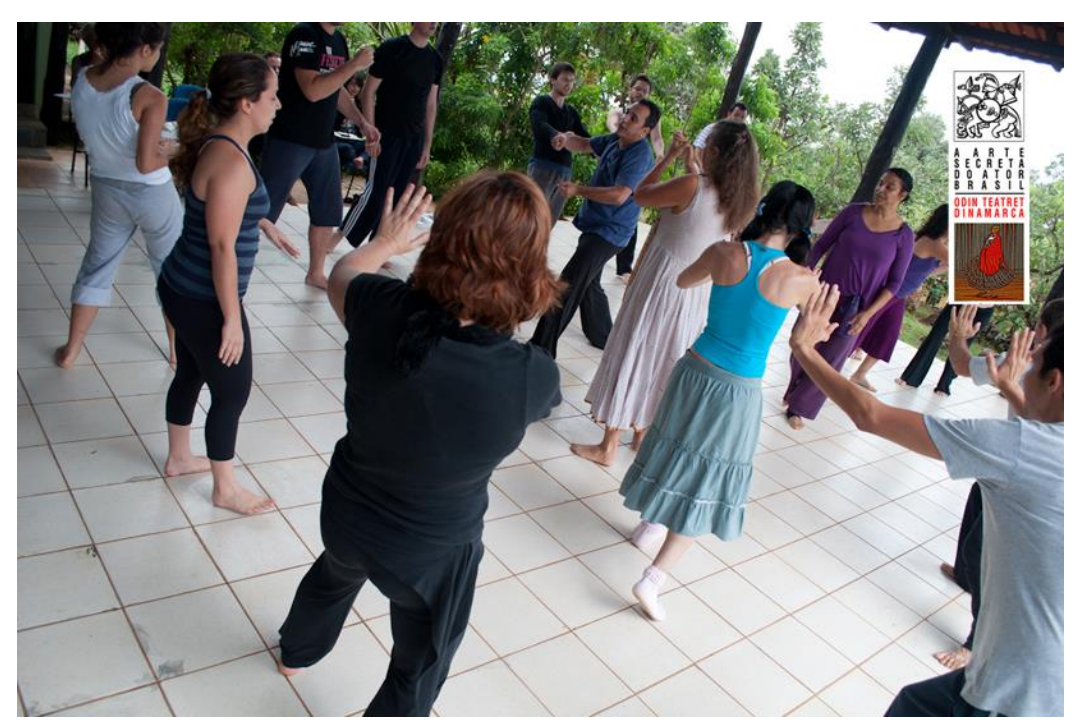

Figura 22. Push and pull-individual. A arte secreta do ator-Brasil, 2010. Foto: Edu Barroso.

\subsubsection{Exercícios com texto e/ou música:}

14. Caminhar ao mesmo tempo em que fala um texto que conheça bem. É imprescindível que realmente se saiba o texto "de cor" $" 238$ para que não haja hesitação durante o exercício que se desdobrará a seguir. A regra é que ao início do movimento deve-se iniciar o texto. Estas ações devem ser sincronizadas: fala e corpo juntos. O andar é em ritmo normal e o texto dito sem pausas, direcionado para a frente, no sentido da caminhada, não deve seguir pontuação nem ter intenções. O que parece simples, falar e andar ao mesmo tempo provou-se como um desafio. Varley apontará pequenas defasagens de sincronicidade que alteram a proposta. Durante os anos de 2011 e 2012, em que estive como observadora, pude ver claramente essa dificuldade, que eu mesma havia experimentado, durante a execução da tarefa: muitos ou começavam a falar antes de andar ou andavam antes de começar a falar, quando a sugestão é que fala e movimento sejam concomitantes ao início das ações.

É interessante que um exercício aparentemente fácil desvele a falta de conexão entre corpo e fala, remetendo à questão do impulso que, seguida a proposta, deve ser simultâneo entre corpo e voz. E, neste simples exercício, temos um pressuposto importante para o que Varley, segundo sua experiência, atribui à credibilidade em cena: o impulso vocal está junto

\footnotetext{
${ }^{238}$ Do latim, cor = coração. Esta é uma expressão muito usada no teatro para designar os textos, decorados pelos atores, que já são ditos de forma fluente, sem parar para pensar no que virá a seguir. Pode-se dizer que é a forma "orgânica" de se dizer o texto. Em inglês: by heart.
} 
com o corporal $^{239}$; qualquer hesitação nesse quesito leva ao questionamento do espectador sobre o que está sendo dito, pois não recria a identificação com a vida.

A partir do exercício anterior, Varley efetua comandos diferentes, introduzidos um a um depois de experimentados pelo grupo durante um tempo, sempre voltando ao "caminhar" contínuo entre os mesmos. São eles ${ }^{240}$ :

- Salto. A esse comando deve-se saltar deixando que a voz siga a tônica corporal e, sem deixar de dizer o texto, voltar a caminhar como em 13. O fato de "saltar" não deve ser equivalente a gritar, tendência notada. A elevação da voz dá-se pela ação física, juntamente com a respiração proporcional ao esforço real e não o suposto.

- Câmera lenta. As ações assumem velocidade menor, no entanto isso não deve ser traduzido como uma fala arrastada, nem uma voz baixa, interiorizada, mas sim, a percepção da respiração do movimento da caminhada lenta influenciando a qualidade da emissão da fala. Outras tendências do lento é barrar o deslocamento e/ou manter a trajetória no mesmo sentido espacial. Nas observações, percebi que esses são "clichês" que se manifestam pela aparente obviedade do comando: "câmera lenta". É a resposta pronta e automática do corpo ao reduzir a velocidade, falar como se estivesse em um filme com problemas de distorção de áudio. Para superar essas tendências há sempre o alerta para que se perceba que a ação é contínua, mesmo que seu fluxo seja diferente e, no caso da fala, manter a premissa de não fazer pausas.

- Correr. A instrução é a mesma, deixar que a voz ecoe a dinâmica corporal, sempre com atenção em que a voz esteja sendo lançada para fora de si e não presa a si mesmo.

- Brincar. Leves saltitos, em deslocamento, com ênfase quando estiver em cima. Deixar a voz subir e descer com o movimento com atenção à sensação física.

- Marchar.

\footnotetext{
${ }^{239}$ Esclarecendo que esta é a proposta deste exercício: começar a ação junto com a fala. Isso não quer dizer que a fala deva sempre se iniciar necessariamente com a primeira ação física. Esta é uma escolha do ator e posteriormente do diretor, sobre a distribuição do texto na partitura. No entanto, a questão da sincronicidade entre impulsos vocais e corporais continua valendo em todos os casos.

${ }^{240}$ Ver figura 12. p. 61. Nessa foto, os comandos não estão mais sendo dados por Varley, e sim cada ator pode variar entre as opções segundo sua escolha dentre as possibilidades.
} 
- Abaixo. Ir ao chão, variando as formas de descer. Ao levantar, tomar cuidado para não esganar a voz, tendência comum relativa ao esforço.

- Ao céu. Projetar-se para cima, porém sem perder o contato com a terra. A voz acompanha a intenção de "ir ao céu".

Entre a intercalação de comandos é importante não reter a respiração ou como diz Varley "prender o cansaço", mas usar as reações dos estímulos permitindo que a voz se projete para fora, mesmo que soe estranha. A dificuldade de modulação, a meu ver, encontrase muitas vezes entre o que achamos que devemos fazer e o que realmente fazemos, segundo os comandos, sendo importante escutar-se e se permitir descobrir novas formas de emissão da voz, timbres e qualidades influenciadas pela ação corporal.

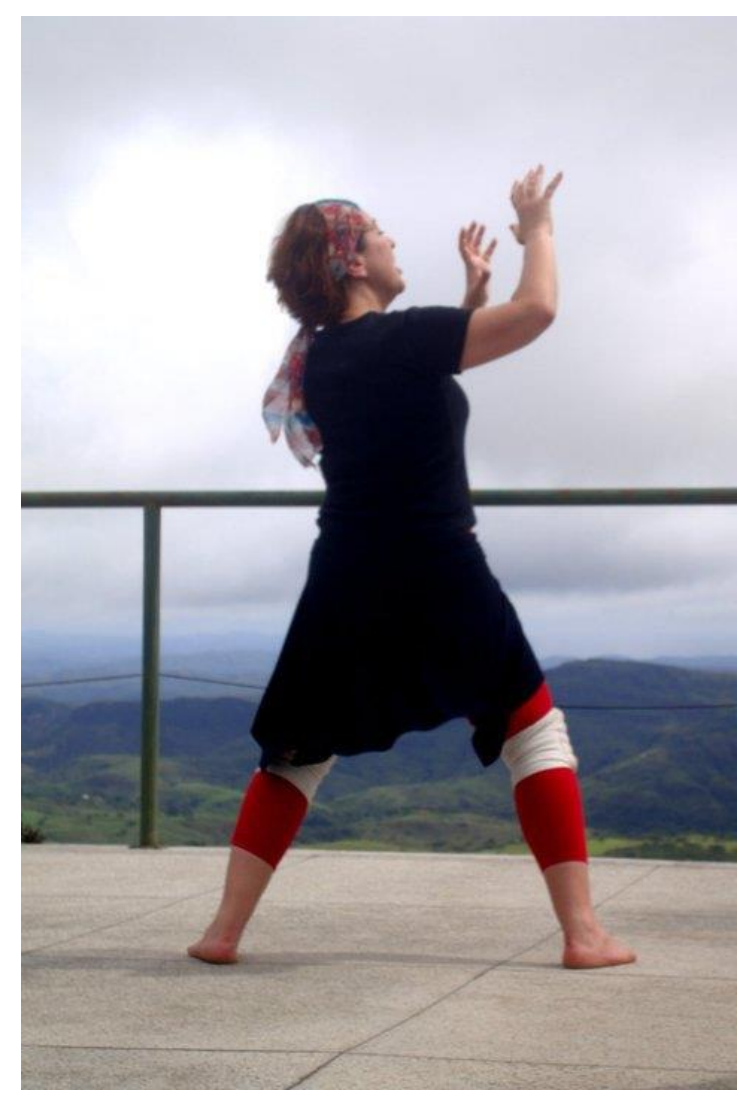

Figura 23. Ao céu. A Arte Secreta do Ator-Brasil, 2010. Foto: Patrícia Furtado de Mendonça. 
15. Em dupla, falando um texto enquanto o par aproxima-se ou se distancia do falante. ${ }^{241}$ Nesse exercício, a voz deve acompanhar a movimentação do outro e variar em intensidade e alcance, dependendo da distância entre si e o outro. O objetivo é trabalhar sobre a tendência que o ator pode ter de manter-se em si mesmo, falando para si. Varley salienta que a voz deve ser sempre dirigida para outra pessoa. ${ }^{242}$

16. Onomatopeias.* Escolher um tipo de trabalho braçal (ex. martelar um prego, carregar pedras, conduzir um carrinho cheio de terra etc.) e atribuir tipos de sons que ajudem a cadenciar o "trabalho", sem a necessidade de ser literal (ex. "pá, pá, pá” para o bater do martelo). Varley traz a imagem de homens colocando trilhos de trens, em filmes antigos, enquanto cantam. ${ }^{243} \mathrm{O}$ canto marcava o trabalho sem ser descritivo. Este exercício pode ser feito em roda com o grupo. Cada um faz sua ação física/vocal duas vezes seguidas e todos repetem.

17. Usar a mesma a ação e cadência descobertas no exercício anterior, colocando um texto. Preservar no texto as qualidades achadas.

18. Composição sonora I.* Em grupo, formar quatro fileiras com a mesma quantidade de pessoas, em forma de cruz. O "regente" fica no meio. Este pede para que o primeiro componente (1a) de uma das fileiras propor um som, que deve ser repetido por toda a sua fileira. O primeiro componente da próxima fileira (1b) propõe outro som, igualmente repetido pela sua fileira, e as duas próximas fazem o mesmo procedimento (1c e 1d). Após todas as fileiras estarem, cada uma com seus respectivos sons,

\footnotetext{
${ }^{241}$ Além de textos decorados, Varley pede-nos para contar algo (pode ser sobre uma viagem) ou dar a opinião sobre algum assunto, p. ex., na Odin Week solicitou que falássemos sobre o que mudaríamos na organização daquele evento. Holstebro, Dinamarca, 25/08/2013.

${ }^{242}$ Em uma oficina com Juliana Carneiro da Cunha, atriz brasileira sediada na França, anotei o que ela chamava de "conselhos de Arianne", referindo-se à Arianne Mnouchkine, diretora do Théâtre du Soleil. Entre elas: "Fale sempre a alguém: ou ao público ou ao personagem ou a Deus. Mas jamais a si mesmo ou ao tapete." SESC Ipiranga, São Paulo, 14/01/1997.

${ }^{243}$ Com relação a isso achamos as work songs folclóricas dos negros escravos dos EUA, cantadas durantes os trabalhos, como a colheita do algodão. Exemplos podem ser conferidos em: <http://pancocojams.blogspot.com.br/2012/09/long-john-lost-john-sound-files-lyrics.html.> Consulta em 28/04/2014. Posteriormente, achamos o equivalente nos cantos de trabalho no Brasil registrados no seguinte documentário: Cantos de Trabalho - Mutirão [Documentário]. "Documentário de Leon Hirszman gravado em 1975-76, essa obra investiga o valor cultural das canções cantadas por trabalhadores no interior do Brasil. Esse episódio, em particular, foi gravado na cidade de Chã Preta - Alagoas". Disponível em: <http://youtu.be/kNTZLi1mUJA> Consulta em: 22/05/2014.
} 
"cantando" juntas, o regente indica para 1a ir para o fim da sua fila. O segundo (2a) propõe um novo som, e assim sucessivamente até todos das respectivas fileiras passarem pelo posto de propor o som. É um trabalho de improvisação dinâmico, que trabalha a escuta em grupo, ritmo e criatividade.

19. Composição sonora II.* Idem ao18, mas com palavras de um texto comum a todos (Ex. "Mas que seja infinito enquanto dure." ${ }^{, 244}$ ). Cada componente escolhe uma palavra. Ex. 1a = infinito; $1 \mathrm{~b}=$ mas; $1 \mathrm{c}=$ seja; $1 \mathrm{~d}=$ enquanto; etc. Usar musicalidades, ritmos, extensões, formas de falar diferentes para as palavras.

20. Costura musical.* Em roda, a partir de músicas trazidas pelos atores em seus "cartões de visita", Varley seleciona trechos, geralmente uma ou duas frase de cada uma, compondo os fragmentos em uma só música. Essa dinâmica se dá primeiramente com o grupo em roda. A "maestra", no centro, aponta para um ator que canta um trecho da sua música, até receber o sinal de parar, enquanto outro é apontado e, por sua vez, canta a dele. Assim, sucessivamente, as frases de cada música são selecionadas e costuradas, formando uma composição plural de melodias e ganhando um novo significado nas junções entre os ritmos e as letras. Metodicamente, o grupo aprende frase a frase das canções, para depois cantar a composição final. A dificuldade está em não assimilar o ritmo da canção anterior, preservando as características de cada trecho em seu tom, melodia e harmonia, e ao mesmo tempo, cuidar para que as transições de um trecho para outro sejam coerentes, às vezes imediatamente interligados, às vezes com breves pausas rítmicas que permitam a passagem e mudança dos aspectos do que será cantado a seguir. Uma vez a música final costurada e assimilada, variações são aplicadas na conformação espacial e volume. Seguindo os comandos da maestra, o grupo junta-se e se afasta do centro, cantando mais alto ou mais baixo, chegando ao sussurro quando todos estão bem próximos uns dos outros. O comando das dinâmicas deve surpreender o grupo, variando na velocidade em aumentar/abaixar o volume, juntar e afastar o grupo, favorecendo os aspectos de atenção, escuta e prontidão.

\footnotetext{
244 Última frase do Soneto da fidelidade. Vinícius de Moraes. Este é um exemplo escolhido por mim, não foi o trecho usado em nenhum dos cursos, nos quais algum texto dos participantes era selecionado para esse exercício. Mas registro, como homenagem, um dos textos trabalhados em 2011, escolhido da cena da saudosa Silvana Abreu (in memoriam), atriz, diretora e pedagoga paulistana e ela mesma, mestra na arte-vida do teatro: "Meu amor não veio/espero/espero/me desespero.” Anotação pessoal, A Arte Secreta do Ator-Brasil, 11/12/2013.
} 
Às vezes pede que o próprio ator faça uma montagem com seus trechos. Sempre recomenda, ao cantar, escuta e atenção sobre como nossa voz está se lançando no espaço; temos que dar segurança à voz, pois senão, o que os outros receberão será nossa preocupação. Em uma instrução durante um dos cursos em Brasília, vendo a dificuldade do grupo em uma música indiana proposta por uma atriz disse: "O corpo sabe muito mais que nossa cabeça, então se você vai [se se permite soltar a voz], provavelmente descobrirá que sabe cantar, ainda que ache as palavras muito estranhas."

21. A voz da imagem.* Neste exercício, em círculo com o grupo, Varley indica um participante e lhe dá uma imagem. A pessoa realiza, em grammelot, ${ }^{245}$ sua versão para a imagem proposta e depois todos copiam o tom e a forma como foi executada. Seguem os exemplos documentados durante os cursos:

a) "a voz da neblina que abraça a igreja de Montevideo";

b) "a voz de uma vendedora de peixes napolitana";

c) "a voz de um gato persa quando é acariciado";

d) "a voz de um político russo no Kremlin em Moscou";

e) "a voz de um cachorro pequinês que se declara para um gato que está no telhado";

f) "a voz da neve que cai no Himalaia";

g) "a voz do hipopótamo dentro da água";

h) "a voz do rouxinol que conta um segredo ao Imperador da China";

i) "a voz de uma leoa que defende seus filhotes".

j) "a voz da chuva caindo nos tetos de metal de Valparaíso ${ }^{246 " . ~}$

Depois se pode colocar um texto ou uma música (a da costura musical, exercício 20, por exemplo), mantendo as qualidades achadas pelo exercício em grammelot. A tendência com a entrada do texto nesse treino é que a dicção das palavras fique prejudicada, tornando incompreensível a fala. $\mathrm{O}$ ator deve então estar atento à clareza da sua dicção sem perder a qualidade das "vozes" achadas anteriormente. Outra observação é sobre uma tendência ao exagero de posições da boca para produzir os sons relacionados às imagens. Varley salienta que a imagem não é um apoio somente do imaginário, mas antes, produtora de tensões vocais,

\footnotetext{
${ }^{245}$ Segundo Dario Fo (1926), ator, dramaturgo, Nobel de Literatura (1997) e grande especialista no uso desse recurso, o grammelot é "um jogo onomatopeico, articulado com arbitrariedade, mas capaz de transmitir, com o acréscimo de gestos, ritmos e sonoridades particulares, um discurso completo." Manual Mínimo do Ator. São Paulo: Ed. SENAC, 1998, p. 97.

${ }^{246}$ Cidade do Chile. Nesse exemplo específico, Varley sugere que consoantes sejam usadas para o barulho da chuva numa superfície de metal.
} 
portanto corporais, que sustentam a pesquisa e a aplicação da "voz" encontrada e fazem com que o som tenha particularidades inusitadas.

\subsubsection{Exercícios com partituras corporais e vocais}

22. Escolher três (3) ações com diferenças de ritmo, direções etc. e encontrar o som de cada ação. Escolher uma frase do próprio texto com 10 palavras. Colocar primeira palavra na primeira ação, a segunda palavra na segunda ação e todas as outras na terceira ação. O objetivo é distribuir o texto nas ações de forma a sincronizá-lo com elas e não ao contrário (ações no texto).

A distribuição do texto pode ser variada, criando diversas combinações, p. ex.: primeira ação = duas palavras; segunda ação = uma palavra; terceira ação = sete palavras. Nestes casos, o importante é adequar o tempo da fala à duração das ações, percebendo e escolhendo o que fica melhor. Deve haver grande atenção à sincronização do texto ao início e fim de cada ação. Isso leva-nos a estender ou acelerar a fala, criando diferenças orgânicas e ao mesmo tempo surpreendentes do modo de falar o texto, quebrando automatismos de pontuação e sentido.

\section{Composição de materiais.*}

a) Lembrar e repetir a partitura dos bastões (= Partitura 1);

b) Lembrar e repetir a partitura das mãos ${ }^{247}$ (= Partitura 2);

c) Realizar uma montagem entre a) e b) (Partitura 1 + Partitura 2 = PARTITURA 3);

d) Lembrar e repetir partitura de formas de andar (= Partitura 4);

e) Inserir d) na montagem realizada em c) (Partitura $4+$ PARTITURA $3=$ PARTITURA 5);

f) Escolher seis ações da cena do "cartão de visitas" (= Partitura 6);

g) Inserir f) na montagem e) (Partitura 6 + PARTITURA 5 = PARTITURA 7);

h) Repetir a PARTITURA 7 até fixá-la bem. É essencial que o ator saiba o começo e fim de cada ação e também conheça as transições de uma ação para outra, a fim de ter clareza e precisão no que está fazendo.

\footnotetext{
${ }^{247}$ Essa partitura foi desenvolvida durante o workshop de 2009, quando Barba pediu que cada ator criasse uma partitura só com as mãos sobre um trecho diferente daquele lhe foi designado no texto de Amoz Oz. Achamos em Grotowski (2009, p.31) uma referência às partituras miniaturizadas como parte da pesquisa da artificialidade: “[...] o princípio fundamental é [...] quanto mais absorvidos nos tornamos pelo que estiver escondido, dentro de nós, no excesso, no desnudamento, no mergulho interior, mais rígida deverá ser a disciplina externa, isto é, a forma, a artificialidade, o ideograma, o sinal. Aqui está todo o princípio da expressividade."
} 
Depois dessa prévia de composição entre as ações, o exercício assume aspectos de exaustão, por ser ininterrupto de h) à gg). Varley aplica os estímulos abaixo, agregando informações que devem ser somadas em camadas permeáveis entre si à PARTITURA 7, sem perda de informação conquistada a cada acréscimo. A passagem de um estímulo para o outro não tem pausas, experimentando no corpo e fixando na estrutura as propostas a seguir:

i) Atenção ao contato dos pés com o chão, às transferências de peso realizadas, à atividade das mãos em cada ação e transição entre as ações, ao foco e intenção do olhar.

j) Realizar a partitura com resistência extrema, como dentro de um bloco de pedra. $\mathrm{O}$ rosto deve ficar relaxado e a respiração normal, apesar do esforço, mas todo o resto do corpo deve estar acionado pela dificuldade de se mover entre a pedra.

k) Mudar para um ambiente de água, estando submerso.

1) Sofrer a ação do vento que decide a direção da ação fazendo com que o ator se mova, segundo a intensidade do "vento" (p. ex. brisa, ventania, tornado etc.).

m) Voltar à PARTITURA 7 em seu normal, "descobrindo" onde de cada ação há vento, água e pedra, criando variedades entre as qualidades das ações. Aplicar essas qualidades às partes escolhidas da partitura.

n) Em câmera lenta, repetir tudo muito devagar. Esse momento deve servir para pesquisar as transições entre as ações, as passagens de peso (uma das premissas sempre repetidas por Barba: transformação de peso em energia) e mapear os detalhes do percurso no espaço.

o) Alta velocidade. Tudo muito rápido. O "rápido" não deve significar perda de precisão, mas sim aceleração extrema.

p) Voltar ao normal, assimilando os momentos em que as ações são em câmera lenta e onde são rápidas.

q) Realizar a partitura de forma exagerada, tudo muito grande, "como um gigante que ocupa todo o espaço".

r) Tudo muito pesado.

s) Muito leve, como voando.

t) Selecionar momentos de peso e leveza, sabendo que a qualidade da ação pode ser mudada também durante sua execução, ou seja, começar leve tornar-se pesada e vice-versa. 
u) Cortar pela metade as ações, mantendo internamente a energia completa. P. ex.: se na partitura há um momento em que o ator se abaixa até o chão, abaixar-se somente até a metade do caminho, porém mantendo as tensões corporais em sua totalidade do movimento completo inicial (abaixar até o chão). Existe uma gradação para esse procedimento: 50\% da ação exterior e 100\% da ação interna.

v) Reduzir ainda mais, aplicando $10 \%$ na ação exterior e mantendo $100 \%$ da ação interna, ou seja, preservando as tonicidades musculares da ação original sem realiza-las completamente no espaço. Os olhos assumem o papel de continuar transmitindo essa intenção espacial ampliada, apesar do pouco movimento aparente.

w) Omissão completa das ações externas: somente pensar e sentir as ações levando à imobilidade ativa. A projeção das ações no espaço continua a cargo dos olhos e das mudanças de fluxo energético no corpo, com atenção às descargas de energia que percorrem a coluna gerando projeções até as extremidades do corpo, provocando ainda sutis, mas potentes, transferências de peso nos pés.

x) Voltar ao normal e escolher, entre as gradações testadas de q) à t), a aplicação em momentos específicos da partitura.

y) Realizar a partitura como uma ginástica militar, com movimentos ritmados e sublinhando o início e o final de cada ação.

z) Mudar para uma realização em fluxo, escondendo os impulsos e começo e fim das ações. A essa dinâmica, tanto Barba quanto Varley chamam de "leite condensado". Esse tipo de movimentação pode ser perigoso quando adotado sem consciência e por muito tempo, por gerar monotonia rítmica, provocando um "deixar-se levar" isento de oposições. Mas, uma vez compreendido, pode ser usado como forma de preservar os impulsos "em segredo", mantendo o trabalho interno do ator.

aa) Voltar ao normal da partitura (lembrando que ao "normal" já estão acrescentadas as escolhas que o ator foi realizando conforme as propostas) identificando os momentos em que as ações necessitam ser sublinhadas e os momentos em os impulsos são escondidos em um aparente fluxo.

bb) Dançar a partitura nos seguintes ritmos: salsa, heavy metal, valsa, ballet clássico, rock etc. e achar os momentos de cada ritmo (ou outros que queira) em suas sequências de ações.

cc) Realizar a partitura a partir de personagens: como Medéia, como Ofélia, como Hamlet, como um guerreiro. Achar nas ações onde está cada personagem. 
dd) Realizar diálogos entre as personagens atribuindo cada uma a partes diferentes do corpo, como um pé sendo Ofélia e outro Hamlet para criar uma história de amor (feliz ou infeliz) entre as ações.

ee) Voltar a PARTITURA 7 lembrando as motivações originais de cada ação.

ff) Realizar a partitura final composta da PARTITURA 7 mais as nuances trabalhadas.

gg) Idem ff) mas em imobilidade ativa, deixando que os impulsos físicos descobertos, as motivações internas, imagens, dinâmicas aconteçam interior e muscularmente, sem realizá-los exteriormente.

Nesse exercício temos um longo percurso de experimentação de possibilidades, trabalhadas a partir de estímulos concretos nas diversas dinâmicas propostas em seus aspectos formais. A partir da assimilação dessas qualidades, o ator pode "limpar" a exterioridade da forma chegando aos impulsos físicos internos que alimentarão sua presença, mesmo que não sejam revelados em suas origens para os espectadores. Para se chegar ao gg), no qual se faz tudo em aparente mobilidade, Varley chama a atenção para o paradoxo: quanto menos se faz externamente, mais se tem que trabalhar com o corpo para sustentar a presença.

Varley dará ainda vários conselhos durante os exercícios: buscar a posição onde tudo é possível do corpo, achar o equilíbrio entre tensão e a intenção para fazer algo; descartar tensões inúteis (nas mãos, boca, pescoço etc.); atenção entre manter a identidade e estar desperto para os outros, para as adaptações etc.; dar a si mesmo tarefas concretas e trabalhar em seus detalhes; desenvolver as capacidades de fixar os detalhes e de repetição; e a identificação dos estímulos que cada um deve encontrar em si mesmo para realizar seu trabalho.

Julia Varley tem um corpo pleno de sinceridade e prontidão. A capacidade de repetir e incessantemente refazer, recriar imediatamente as tensões corporais originais. Ela conta que o segredo está nos seus pés e coluna. Em como pisa, no que pisa. O impulso original é recriado e refletido no corpo, sustentando a originalidade da ação, mesmo que feita pela milésima vez. Ela situa o "coração da ação" no torso, como uma pequena explosão das mudanças de tensão, que pode variar de intensidade de uma para outra. ${ }^{248}$ A nomeação que dá para esse acontecimento no corpo durante a ação, segundo ela, pode variar de pessoa para pessoa; essa foi a sua formulação em palavras para transmitir como ensinamento a percepção dessas

${ }^{248}$ Em entrevista concedida a mim durante Odin Week, Holstebro, 23/08/2013. 
nuances de tensão da ação, e que para ela é aquilo que tem que ser protegido. Também chamará de coração aos achados das personagens, exemplificando com o "andar com os braços" da personagem Nikita de Vida Crônica, que se torna um ponto de referência para toda a forma de ser em cena. ${ }^{249}$.

\subsubsection{Tradição Roberta Carreri}

Roberta Carreri traz em seus ensinamentos uma pedagogia estruturada pelas influências dos mestres asiáticos que teve e dos exercícios aprendidos com atores mais antigos do Odin Teatret. Sua oficina, denominada Dança das intenções foi cursada por mim três vezes, sendo a primeira em São Paulo, em janeiro de 2013, a segunda em Holstebro, em agosto de 2013 e a terceira, qualificada como "aprofundamento", novamente em São Paulo, ${ }^{250}$ em novembro de 2013.

Segundo ela, "o método é uma sala com pessoas querendo trabalhar" e no espaço de trabalho, além do que está sendo realizado, a quarta dimensão que o ator alcança é o respeito pelo ambiente, por seu treinamento e colegas e a consciência de que tudo o que uma pessoa faz tem consequências para o todo. ${ }^{251} \mathrm{O}$ objetivo é a presença cênica dominada a partir de procedimentos claros e recheados de interioridade viva e latente. Os olhos/olhar têm grande importância na sua tradição. Diz que o ator deve olhar de maneira ativa: "Cinquenta por cento do trabalho do ator está em aprender a ver." 252 Pelos olhos também devem ser comunicadas as intenções e suas gradações são treinadas em exercícios específicos, relatados nas descrições que se seguirão.

Ela estrutura o corpo baseado na imagem de uma coluna-serpente - que contém a essência de todas as ações - incorporada do cóccix aos olhos e que é a morada do que chama de in-tensão (2010, p. 43). Carreri trabalha as intenções sob o aspecto de que cada ação é uma

\footnotetext{
${ }^{249}$ Entrevista concedida a mim durante Odin Week, 23/08/2013. Cf. também o programa do espetáculo Vida Crônica, 2011, p. 37.

${ }^{250}$ A duas oficinas em São Paulo foram promovidas pela Cia Mundu Rodá de Teatro Físico e Dança, fundada pelos artistas Juliana Pardo e Alício Amaral e hospedadas no Centro Iyengar YOGA.

${ }^{251}$ Anotação pessoal. A dança das intenções, 25/01/2013.

${ }^{252}$ Anotação pessoal. A dança das intenções-aprofundamento, São Paulo, 08/11/13.
} 
reação, que por sua vez tem uma intensão ${ }^{253}$ específica que altera o tônus muscular (p. 98). Na "dança das intenções”, cabe ao ator não antecipar a ação, mas provocar no espectador associações por meio de mudanças das in-tensões internas, mantendo seu interesse (p. 99).

Nos cursos, fala ainda em um "grande filé mignon", um músculo fictício que vai dos calcanhares, passando por toda a parte posterior das pernas e costas e que chega pelo crânio até os olhos, como apoio ao entendimento dessa grande extensão, que é também muscular e que está comprometida na realização das ações. No seu vocabulário, associado à serpente, isso seria nossa "anaconda".

Carreri divide as fases de seu treinamento em quatro estações, sendo a primeira durante seu ingresso no grupo quando aprendeu os exercícios do repertório de outros atores, diretamente influenciados pelo treinamento que era aplicado por Grotowski e que incluíam os exercícios plásticos e acrobáticos. Depois, na segunda estação, desenvolveu seu treinamento pessoal e começou a sistematizar mais claramente os procedimentos. No próximo estágio, conta que percebeu que havia assimilado os princípios de tal forma, que, enquanto realizava o treinamento, sua mente se descolava do momento presente e sentiu que precisava de novos desafios. Entrou aí na sua terceira estação, diminuindo propositalmente a mobilidade a que estava acostumada, e "sentando-se" para achar novas possibilidades. Foi quando desenvolveu o exercício da segmentação, que a obrigava a trabalhar quase imóvel, elegendo partes do corpo para se moverem independentemente. A quarta estação é a fase atual, na qual dá atenção às formas de dramaturgia do ator e os elementos que utiliza. ${ }^{254}$

Seu treinamento envolve:

A) Domínio do equilíbrio, transferência de peso e fortalecimento dos tornozelos.*

- Em pé, partindo de pés paralelos, transferir o peso para uma das pernas enquanto coloca o outro pé apoiado no chão em ponta. Transferir o peso para o pé em ponta ao

\footnotetext{
${ }^{253}$ Nos apontamentos de Bonfitto (2013, p. 109) sobre ambivalências entre intensão e intenção, encontramos relações com a abordagem de Carreri. Apoiado nos conceitos de Daniel Dennet, para quem a intencionalidade é tomada em seu sentido filosófico, ou seja, relacionalidade, a intenção refere-se ao aspecto mais abrangente que é comparado a "flechas metafóricas apontadas para outra coisa"; já a intensão "envolve diferentes níveis de articulação subjetiva" ao atribuir uma "maneira particular pela qual essa coisa, ou conjunto de coisas, é selecionada e determinada."

254 Anotações pessoais sobre Traces in the snow, demonstração de trabalho assistida durante a Odin Week, Holstebro, Dinamarca, 21/08/2014. Achamos também em Carreri (2011, p. 46) referências às estações de seu treinamento.
} 
mesmo tempo em que subir em elevé $e^{255}$ (meia-ponta) e elevar a outra perna, dobrando o joelho à $90^{\circ}$; descer com controle, lentamente. Manter braços relaxados ao longo do corpo e face sem tensões;

- Saltitos com os dois pés ao mesmo tempo, cuidando de não fazer barulho ao pousar. Há uma grande atenção à articulação dos pés, com uso completo das fases do "pouso", dedos, metatarsos, calcanhares.

- Exploração de formas no espaço, como estátuas art-noveau, trabalhando sempre na meia-ponta e em uma só base, sendo que a transferência deve ser imediata para outra forma e assim sucessivamente. Esse exercício, além de trabalhar os elementos listados em A, promove várias oposições e torções no corpo.

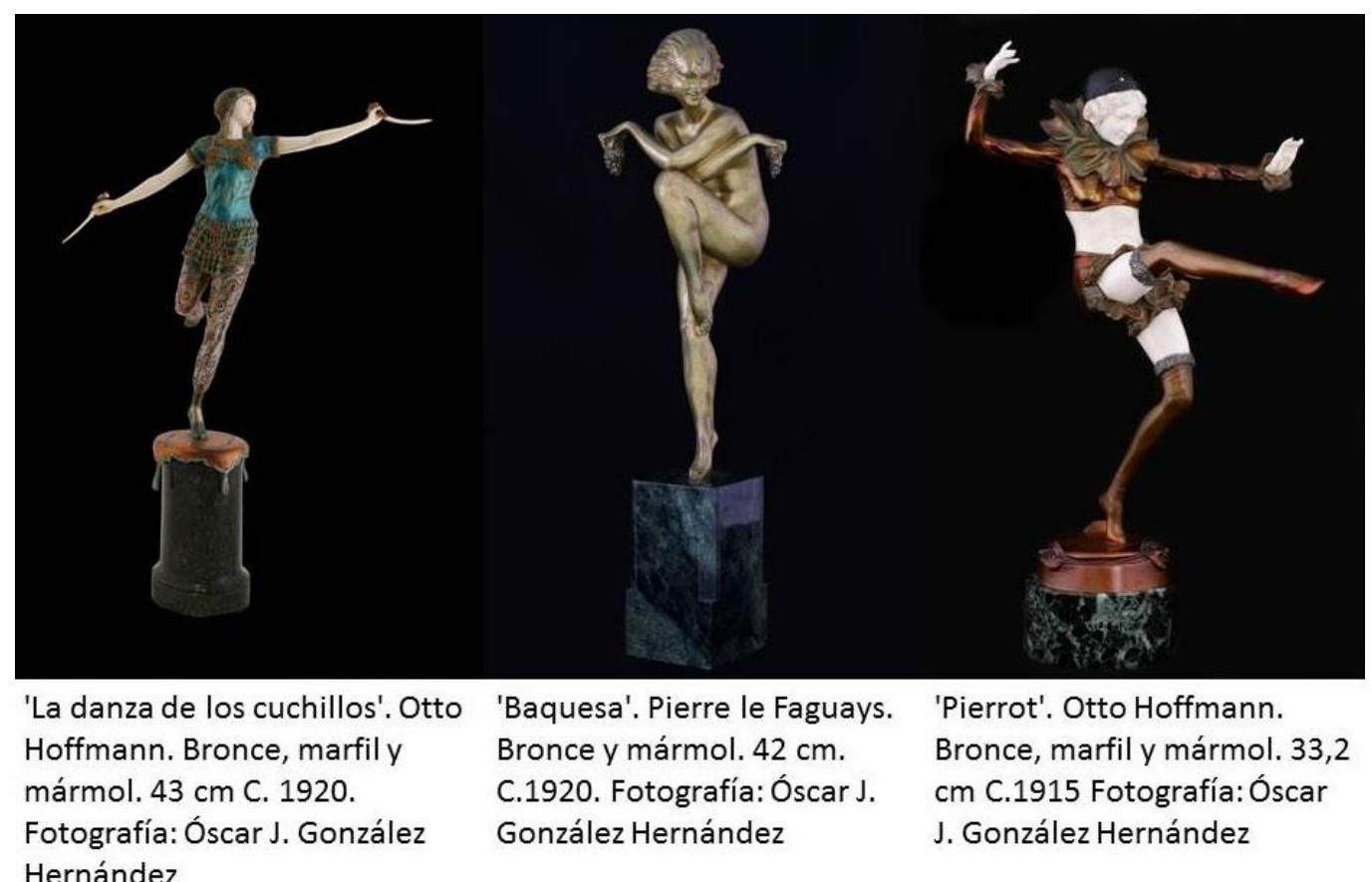

Figura 24. Inspirações da art-noveau ${ }^{256}$.

B) Escuta.* Em grupo, a partir de uma formação linear, lado a lado, cada ator deve entrar no espaço, um por vez, sem "buracos”, ou seja, sem que haja intervalos entre as entradas nem

\footnotetext{
255 Termo do Ballet clássico, em francês significa elevar, usado por mim aqui para descrever o ato de apoiar dedos e metatarsos, elevando o calcanhar. O elevé não tem plié (dobrar o joelho) em sua preparação e nem salto em sua execução. Carreri vai usar o exemplo de "subir no salto alto".

${ }^{256}$ Montagem nossa. As imagens dessa figura provêm do Museo Art Noveau y Art Déco. Não achamos a política de uso de imagens no site, adotando a orientação do Museu do Louvre sobre esse tipo de procedimento, que permite a reprodução para uso não comercial, com os devidos créditos. Imagens disponíveis em:

<http://www.museocasalis.org/nuevaweb/coleccion/criselefantinas-bronces>. Acesso em: 05/06/2014.
} 
saídas ao mesmo tempo em que outro. Quem entra no espaço deve andar até um ponto e mudar de direção, parando no ponto escolhido. A parada deve ser precisa, sem braços balançando para que não haja hesitação no grupo sobre a "deixa" para o próximo a entrar. Sucessivamente os outros atores devem ir ocupando o espaço de forma que este fique equilibrado com a distribuição dos corpos. Carreri usa a imagem de uma balsa, que não pode ter peso excessivo em um só dos lados para não virar.

C) Prontidão.* Ao seu comando:

- agachar até o chão (preparação) e dar saltos de $180^{\circ}$ no lugar, sem barulho ao pousar;

- correr, também evitando fazer barulho com os passos;

- parar (stop) com trabalho de imobilidade ativa (continuar correndo com o olhar), mantendo o pulso interior chamado a qualquer momento para se manifestar no próximo comando.

As formas de comandos usados são palmas para o salto e as próprias palavras (correr/stop) para os outros. Entre correr e saltar, quando se está no stop, o ministrante pode criar "suspenses" sobre o que virá, ameaçando bater palmas e dando o comando de correr, aumentando o estado de atenção do grupo.

D) Consciência da coluna vertebral.* Carreri trabalha com imagens:

- Alga marinha: com pés paralelos, leves oscilações laterais da coluna vertebral, o olhar é "solto", sem foco e se move com a oscilação da coluna.

- Água-viva: ${ }^{257}$ os braços entram no movimento, a partir da movimentação da coluna, como flutuando na água. A forma é redonda e lenta.

- Serpente: $:^{258}$ as oscilações laterais da coluna ficam mais visíveis, braços realizam a ação de empurrar o espaço; olhos acompanham as mãos, também com a intenção de empurrar. Isso não quer dizer olhar para as mãos e sim seguir a direção com o olhar.

- Naja: em leve flexão das pernas, com pés e joelhos paralelos, apontando para a frente; quadril levemente rotado para a frente, em $k o s h i^{259}$, retificando a coluna; mãos

\footnotetext{
${ }^{257}$ Carreri também chama esse exercício de anêmona, que apesar de ser espécie diferente da água-viva, no exercício segue as mesmas orientações. Anotação pessoal, A dança das intenções, São Paulo, 24/01/2013.

258 Também chamada por Carreri de "vípera mediterrânea". Anotação pessoal, idem.
} 
apoiadas na virilha com espaço nas axilas; queixo levemente apontado para baixo, gerando uma distensão e crescimento na nuca; olhar direcionado para o horizonte. Essa postura vem diretamente de seu treinamento com Katsuko Azuma, mestra da dança clássica japonesa Nihon Buyô (CARRERI, 2011, p. 137). As tensões que descobriu em seu corpo durante essa experiência que deram origem ao que nomina como in-tensão. Carreri descreve:

A parte de trás do pescoço está sempre estirada enquanto o queixo está apontando para baixo, como se um fio de aço preso ao osso occipital puxasse para cima, enquanto a outra extremidade do fio puxasse para baixo a partir do final da coluna vertebral. $^{260}$

No treinamento de Carreri, essa postura é usada para trabalhar também a força do olhar com intenção de furar o espaço, olhar direto, forte, como o veneno lançado. ${ }^{261}$ Em suas palavras, podemos "queimar o ponto" para onde o olhar é dirigido.

Nessa postura, trabalhará o jo-ha-kyu $u^{262}$, orientando a passagem do andar muito lento até sua aceleração gradativa e o momento de parada/suspensão em seu ápice, atentando à energia acumulada e à sua contenção na imobilidade ativa. Segundo ela, a prática dos dinamismos do jo-ha-kyu, elucidou a necessidade de criar uma resistência interna que se opõe ao movimento (apud RISUM, 1994/95, p. 51). Para experimentarmos essa possibilidade, fizemos um exercício em duplas, no qual o par segura o outro pelas cristas ilíacas, ambos na postura Naja, oferecendo resistência ao andar e liberando gradualmente a força para permitir maior velocidade no deslocamento.

\footnotetext{
${ }^{259}$ Literalmente "quadril" em japonês. O conceito do koshi para o ator provém de técnicas orientais do Kabuki e Nô e implica bloquear o movimento do quadril ao caminhar, gerando tensões diferentes entre tronco e pernas, provocando outra forma de equilíbrio (BARBA \& SAVARESE, 2012, p. 18).

${ }^{260}$ Tradução nossa. Original: "La parte posterior de la nuca esta siempre estirada mientras que la barbilla apunta hacia abajo, como si un hilo de acero atado al hueso occiptal tirase hacia arriba al mismo tiempo que el otro cabo del hilo tirase abajo desde el final de la espina dorsal.” (apud RISUM, 1994/95, p. 51)

261 Em meu vocabulário pessoal, costumo usar a imagem do "olhar de raio laser" herdada do treinamento realizado com diretor/ator Gonzaga Pedrosa.

${ }^{262}$ Da tradição do teatro japonês, segundo Barba, é a expressão que define três fases da ação do ator: jo corresponde à oposição entre reter e soltar, ha é momento de liberação da força retida e kyu é o ápice que essa força alcança para reter-se novamente em jo (2009, p. 61). Cf. também, BARBA \& SAVARESE, p. 26 e 254.
} 


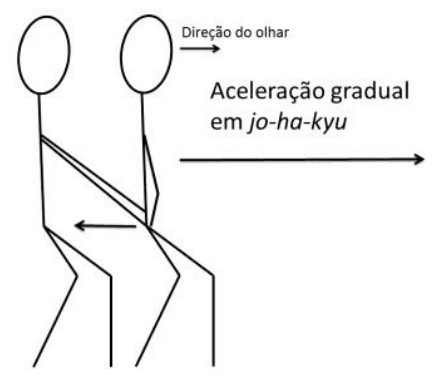

Figura 25. Naja e jo-ha-kyu em pares ${ }^{263}$

D) Ações: realizadas pelo espaço e em movimento contínuo.

- Lançar.

- Parar.

- Chamar.

- Apontar.

- Pisar (em algo mole, como uma lesma, gerando uma reação de recolher o pé rapidamente. Carreri explica que essa reação provém do abdômen em uma contração que faz recolher a perna).

- Dar um basta (ação com mãos e pés).

- Chutar.

- Roda. Esse é o nome dado por ela para uma movimentação que consiste em passos contínuos, que identifiquei com um pequeno "moonwalk",264 em deslocamento frontal.

Todas as ações são trabalhadas, uma a uma, pelo espaço e explorando várias formas de realizá-las. Há comandos no sentido de qualidades da ação podendo-se explorar variações de tamanho (grande/pequeno), intensidade (suave/forte), e ritmo (rápido/lento). Também se explora o rewind, ou seja, a forma de "rebobinar" cada ação, achando-se outras possibilidades e intenções na ação transformada. Depois, conjugam-se em sequências de ações, a fim de achar as transições de uma à outra de forma dinâmica e sucessiva, até que se tenha uma série encadeada de todas as ações praticadas. Sempre será destacado para ficarmos atentos às

\footnotetext{
${ }^{263}$ Os desenhos desta e das figuras constantes na Tradição de Tage Larsen (p. 160-162.) são réplicas ou adaptações dos desenhos em meu diário de bordo, referentes aos cursos com os profissionais, executados por mim com recursos do programa power point.

${ }^{264}$ Célebre passo de dança criado por Michael Jackson (1958-2009).
} 
intenções que surgem com as ações, deixando o olhar participar para que essas dinâmicas internas tornem-se visíveis para quem está assistindo.

Carreri muitas vezes promove, com música, uma "dança" pelo espaço, com as ações trabalhadas.

E) Olhar.

- Exercícios do Kathakali: manter os olhos bem abertos com a ajuda dos dedos ${ }^{265}$.

a) Deslocar os olhos em linha reta (horizonte) da esquerda para a direita e vice-versa, sucessivamente;

b) Deslocar os olhos em arco para cima da esquerda para a direita e vice-versa, sucessivamente;

c) Deslocar os olhos em arco para baixo da esquerda para a direita e vice-versa, sucessivamente;

d) Rotações circulares completas no sentido horário e anti-horário;

e) Deslocar os olhos em diagonal, da direita alta para a esquerda baixa, indo e voltando entre os dois pontos, sucessivamente $T_{\text {E vice-versa. }}$

- A partir de e), mas sem a ajuda das mãos para abrir os olhos, "cortar o espaço", como se os olhos fossem lâminas;

- Olhando para um ponto fixo, na linha do horizonte, aproximar e recuar a intensidade do olhar. Quando aproximar "queimar o ponto" com os olhos, quando recuar, parar na superfície do olhar e depois voltá-lo para "trás". Conforme o olhar retrocede para a superfície e para dentro do crânio, ocorre um desfoque do ponto fixo inicial. Uma tendência é olhar para baixo na última fase, sendo, no entanto recomendado manter a linha do horizonte. Fazer o movimento inverso, de dentro para fora, até "queimar o ponto" novamente. A face deve ficar serena, não é preciso fazer caretas nem mexer demasiadamente as pálpebras.

- Olhar o espaço com as qualidades de "voo de borboleta; limpador de para-brisa; cortinas de voal" (um tecido muito leve) balançando ao vento.

F) Slow motion ${ }^{266}$ (Câmera lenta). Andando pelo espaço, com elevação da perna - que a cada passo inicia o movimento a partir de trás, sendo conduzida à frente do corpo em rotação pela

\footnotetext{
${ }^{265}$ Para uma referência desse procedimento cf. BARBA \& SAVARESE, 2012, p. 174, ilustração [2].

${ }^{266}$ Carreri (2011, p.49-52) descreve o exercício em detalhes em seu livro.
} 
coxo-femural e mantida acima do chão, como se fosse passar por cima de um obstáculo, uma cadeira fictícia, p. ex. - o deslocamento se dá de forma muito lenta, executando a transferência de peso de uma base para outra. São inseridos, ao longo da prática, comandos de sentar e levantar, ir para os lados ou atrás, mantendo o ritmo lento em todas as opções. Ao sentar não se entregar ao chão, mas usar o contato para o imediato levantar-se, sem que esse impulso fique claro, no entanto. Nesse trabalho podemos identificar o princípio da oposição claramente. É necessário estabelecê-las para garantir o equilíbrio no deslocamento e controlar as ações de sentar e levantar. A fluidez também é uma qualidade trabalhada, na medida em que os impulsos são "escondidos" e a sequência de movimentos é ininterrupta e constante. Ainda mais uma proposta é inserida durante o exercício: subitamente "levar um tiro" e reagir ao impacto, consciente da parte do corpo que foi "atingida". Ao "morrer", ir ao chão lentamente, caindo sem controle da forma em que se vai deitar e permitindo que o olhar também regrida à superfície. Uma vez no chão, ser "erguido por um anjo", que te levanta por uma parte específica do corpo.

É relevante salientar a orientação de que esse exercício deriva da aplicação da serpente na coluna. É a partir da coluna que o movimento se dá, determinando a ação e permitindo sua metamorfose.

G) Leading points (pontos de condução ou liderança, em livre tradução). Os leading points, são pontos de partida no corpo escolhidos para dar início à ação e conduzi-la pelo espaço. São treinados isoladamente, na ação de andar, partindo da/o(s):

a. Cabeça: testa; parte de trás do crânio; e, acrescentando uma possibilidade treinada por mim, orelhas;

b. Tórax: peito e da coluna torácica;

c. Ombros: rotação para frente, para trás, vetor lateral;

d. Quadril: cristas ilíacas e sacro;

e. Joelhos e atrás dos joelhos;

f. Pés: ponta dos pés, calcanhares.

Em cada uma dessas aplicações, há um leve desequilíbrio inicial que leva o corpo para o caminhar a partir dos pontos escolhidos. Há sutis ênfases como pequena rotação dos ombros para frente ou para trás, evidenciando o ponto selecionado e sua direção. Esses micromovimentos promovem diferenças musculares e posturais, trazendo signos que podem 
ser trabalhados na construção da partitura da personagem, por exemplo, como a introversão do ombro, ou projeção do externo podem configurar dados da personalidade da personagem. São treinadas também formas de girar a partir dos ombros e quadris, tomando esses pontos como condutores do consequente movimento do resto do corpo. Ainda são experimentados os cotovelos e parte interna do antebraço e os punhos como leading points. Cada uma das escolhas trazem leituras corporais diferentes, abrindo possibilidades de intenção conforme a postura adotada.

H) Segmentação. O trabalho de segmentação é apresentado por Carreri (2011, p. 87-90) como uma descoberta de sua segunda estação de treinamento, quando, já apropriada dos princípios e sentindo que incorria em automatismos, reduziu todas as ações, mobilizando apenas partes do corpo a fim de evidenciar as ações específicas e, com isso, achou o efeito de close up, que destaca partes do corpo, enquanto as outras estão imóveis.

I) Introversão/extroversão. "Fechar e abrir" ombros, quadris, joelhos, cabeça, braços, estabelecendo "um diálogo entre as diversas partes do corpo." (2011, p. 59). Carreri demonstra como características da personalidade de uma personagem podem surgir e ajudar na construção corporal de modos de andar e se comportar da mesma no exemplo presente em sua demonstração de trabalho, Traces in the snow, possibilitando várias combinações e composições em relação às partes do corpo trabalhadas bem como com o espaço, assumindo direções diferentes como diagonais etc.

J) Voz. Carreri trabalha com os ressonadores localizados no baixo ventre, peito, boca, cabeça (testa) e topo da cabeça. É uma herança dos exercícios do Teatr-Laboratorium que Barba aprendeu no tempo com Grotowski (CARRERI, 2011, p. 163). Desenvolveu uma preparação respiratória com ênfase no estado de relaxamento e consciência do tempo de inspiração/expiração conectado à duração do movimento.

1. Deitado em decúbito dorsal, pernas dobradas, pés apoiados no chão, braços em cruz (posição inicial), inspirar, ao mesmo tempo em que traz o braço direito por cima do corpo, em arco, até alcançar a mão do lado esquerdo, deixando que o corpo todo se vire em posição fetal. Manter apneia de três tempos. Voltar expirando até a posição inicial, com o braço direito comandando a ação e traçando o arco por cima do tronco. Na posição inicial, manter apneia de três tempos antes de inspirar novamente, repetindo o exercício. Inverter o braço que 
comanda, realizando o mesmo exercício para o lado oposto. O número de repetições variou de cinco (5) a oito (8) vezes para cada lado.

2. Idem ao exercício anterior, mas passando o braço pelo chão, em arco acima da cabeça, e invertendo inspiração e expiração. Portanto: expirar ao levar uma mão de encontro à outra e inspirar ao voltar à posição inicial.

3. Na posição inicial, produzir um som em boca chiusa ${ }^{267}$ (“mmm”) nos ressonadores citados. Carreri instrui-nos a, como conquistadores, fincar uma "bandeira" em cada ponto de ressonância do corpo, sabendo voltar imediatamente a cada um, sem ter que descobri-los de novo.

4. Deixar sair vogais com a mesma intensidade do som produzido em "m", sem mudar o tom, explorando os ressonadores.

5. Levantar-se lentamente com um ressonador escolhido e som de alguma vogal, evitando variações ou oscilações de tom ou volume.

6. Em pé, trabalhar uma frase do próprio texto em ressonadores diferentes.

7. Em seguida Carreri propõe várias imagens para aplicarmos à emissão do texto. Eu as chamo de "Qualidades da água”. Segundo minhas anotações, são elas:

a) neblina;

b) rio Amazonas;

c) tempestade no mar;

d) riacho/corredeira;

e) borbulhas de água fervendo.

$\mathrm{Na}$ experimentação com cada uma dessas imagens, percebemos que a voz automaticamente sai de um dos ressonadores, além de acrescentar variações de tom e intenções à forma de falar o texto, sendo a) = ventre; b) = peito; c) = boca; d) = testa; e) = topo da cabeça. Carreri também propõe outras imagens, algumas semelhantes às de Varley,

\footnotetext{
${ }^{267}$ Boca chiusa: "com a boca fechada - indicação para os cantores vocalizarem sem palavras, mantendo os lábios cerrados, mas os dentes ligeiramente afastados.” (ISAACS; MARTIN, 1981, p. 47).
} 
como "gato branco, vendedora de peixes, sargento, relâmpago, borbulhas de champanhe, mar em revolta, oração" 268 para testarmos as qualidades da voz e seus ressonadores.

Ainda são parte do treinamento de voz exercícios de vocal fry ${ }^{269}$; e exercícios em que, segundo uma proposta de som (POW), é possível trabalhar a precisão e circularidade da voz dentro e fora do corpo. Estes últimos são exercícios inventados por ela a fim de treinar a passagem do som para trás da cabeça sem quebras. O som POW é emitido precisamente, e como com uma batuta na mão, traçando um arco ascendente para trás, direcionamos seu percurso e duração.

Trabalhamos brevemente os "harmônicos", em um exercício em que o som é mandado para o topo da cabeça e, em movimentos circulares orquestrados pela mão como batuta, percebemos as variações possíveis dos tons. É muito difícil descrever esse exercício, por sua característica em trabalhar com a ressonância na caixa craniana, em uma base grave e ao mesmo tempo produzindo o som acima do agudo com variações de tom, uma vez conseguida tal situação ressonadora. $\mathrm{O}$ posicionamento da língua também exerce influência na qualidade do som emitido. Carreri (2011, p. 168) descreve essa qualidade comparando-a ao som produzido quando se fricciona, com a ponta do dedo, a borda de um copo de cristal. ${ }^{270}$

Em questão sobre sua experiência pedagógica durante entrevista concedida a mim, Carreri fala da necessidade de transcendência inerente a qualquer ser humano e situa a transmissão do conhecimento como parte dessa transcendência. Ao ministrar aulas, ela sente que seu conhecimento pode ficar como "uma pequena faísca de eternidade" e não morrerá com ela. Salienta que o que tem procurado enfatizar "é a sensação do centro, do eixo, do que eu chamo a serpente, o que para mim é onde moram as intenções, é o que fica na base das

\footnotetext{
${ }^{268}$ Anotação pessoal. A dança das intenções, São Paulo, 22/01/2013.

269 Carreri não usa esse termo técnico, mas identifico o procedimento por outros treinamentos que já experimentei com profissionais de fonoaudiologia. Conceituando: "O vocal fry é uma técnica fonoaudiológica caracterizada por um procedimento básico, isto é, emissão contínua em registro pulsátil, com 'a' sustentado repetidas vezes, som produzido semelhante ao 'motor de barco'. Originalmente, essa técnica atua no nível glótico, promovendo grande contração do músculo tiroaritenoideo, relaxamento do músculo cricotireoideo, mobilização e relaxamento da mucosa, fonação confortável após o exercício, além da melhor coaptação glótica (Behlau et al., 1997)." Apud SERRANO, Daniela M. S. et al. Disponível em <http://revistas.pucsp.br/index.php/dic/article/view/11678>. Acesso em: 27/03/2014.

${ }^{270}$ Segundo Carreri (2011, p. 168) essa técnica foi introduzida nos anos 1980 no Odin Teatret sendo aprimorada para o uso no espetáculo Mythos, ao final dos 1990. Podemos vê-la exercitando os harmônicos no vídeo de Traces in the snow (especificamente em $1 \mathrm{~h} 29$ do vídeo).
} 
ações, é o que confere credibilidade ao ator." ${ }^{271} \mathrm{Na}$ abordagem sobre possíveis inovações ao "método", declara constante reelaboração e reinvenção do que já existe:

Isso, o método, é uma sala, pessoas motivadas e tempo. Esse é o método. Não tem outra coisa, não tem outro elemento nesse método. Isso indica que eu sigo inventando. Eu, com vocês, faço de conta que nada foi feito antes. [...] Cada vez que eu faço o seminário eu tenho todo o conhecimento dentro de mim, mas eu me enfrento com essas pessoas, aqui e agora. São certos princípios que eu emprego, mas têm coisas que eu faço e [outras] que eu não faço, porque têm muitos [princípios] para passar. Então, o que eu elejo, escolho como menu, é diferente de cada vez. Não somente nas minhas demonstrações de trabalho, mas também nos seminários. Por isso eu gasto muita energia nos seminários, porque eu estou 101 por cento dançando com a energia dos alunos e com a necessidade que eu vejo brotar. É uma forma de performance de quatro horas, porque é uma improvisação, então nunca é rotina. $(25 / 01 / 2013)$

\subsubsection{Tradição Iben Nagel Hasmussen}

A sua oficina foi cursada durante a Odin Week, na apresentação de sua tradição ${ }^{272}$. Rasmussen inventou sozinha, e também junto ao seu grupo, vários exercícios que fizeram parte do treinamento transmitido aos atores ingressantes no Odin Teatret e que fazem parte, até hoje, das noções da construção do corpo pensante do ator. A transmissão dessas noções, segundo ela (apud CHRISTOFFERSEN, 1993, p.174), a ensinou bastante ao lhe dar a oportunidade de descobrir seus erros e passar para frente o que é essencial, assim como a oportunidade de verificar se os seus princípios são objetivos e têm valor para outras pessoas, além de si mesma.

$\mathrm{Na}$ experiência durante a Odin Week, suas pupilas, Sofia Monsalve e Elena Floris demonstraram a Dança dos Ventos ${ }^{273}$, um dos exercícios mais populares quando se fala das técnicas disseminadas por atores do Odin Teatret. Essa dança foi criada por membros do grupo Ponte dos Ventos e compreende o deslocamento no espaço com pequenos saltos em três

\footnotetext{
${ }^{271}$ Entrevista realizada em São Paulo, 25/01/2013.

${ }^{272}$ Holstebro, Dinamarca, 20/08/13.

${ }^{273}$ O grupo LUME, através de Carlos Simionni - membro da Ponte dos Ventos - é um dos divulgadores desse exercício, bem como de outros da tradição de Iben Hasmunssen no Brasil. Ricardo Ferracini, em A Arte de não interpretar como poesia corpórea para o ator ( $2^{\mathrm{a}}$ ed. 2003) descreve detalhadamente os exercícios Dança dos ventos (p. 171), Samurai (p. 174), Verde. (p. 164), Fora do equilíbrio (p. 178), entre outros da tradição de Rasmussen. Cf. também Mariz, 2008, p. 171-180.
} 
tempos associados à respiração e transferência de peso, e cuja tônica está no impulso, na saída do chão. Durante essa dança, há, ou melhor, pode haver, pausas (stop) para momentos de "lançamentos", que devem comprometer o corpo todo e serem precisos, acompanhados do olhar para a direção em que o lançamento é executado. Francesca Romana Rietti ${ }^{274}$ registrou as seguintes orientações de Rasmussen sobre as pausas durante a dança, em um seminário de Ponte dos Ventos, na Dinamarca, em 1997:

\begin{abstract}
Nunca se esqueça de que, durante o stop, o peso está sempre em uma só perna, nunca no meio e nem sobre ambas. É importante que no momento da parada na dança, ação não morra dentro de você. Quando você parar, a tensão não deve desaparecer do corpo. Realizar um stop não significa parar e ficar "na posição". A posição é vazia porque nela a intenção morre. A "barriga", no entanto, não deve morrer nunca. Eu vejo que muitos de vocês, preocupados com o stop, eles perdem a riqueza e a beleza das imagens que tinham encontrado com a dança. ${ }^{275}$
\end{abstract}

O Samurai consiste de uma postura alcançada com as pernas afastadas na largura dos ombros, paralelas, com os joelhos semiflexionados e tronco ereto. Rasmussen pontua que este exercício se baseia em uma "energia forte, sólida, entregue a terra e ao peso do corpo" (2001, p.3). As mãos carregam um bastão, real ou imaginário. É uma postura que traz a energia do guerreiro. Seu deslocamento se dá em ações de ataque e defesa, sem oscilar a altura da cabeça, mantendo sempre os joelhos semiflexionados. Ainda são treinadas formas de sentar e levantar e possibilidades de mudança de direção. Contraposto ao "samurai", há o exercício que convoca a imagem da "gueixa", com qualidades de leveza e da energia feminina ${ }^{276}$. Como nota Mariz (2008, p. 176), não se trata de uma distinção de gêneros, mas uma solução encontrada por Rasmussen e seus atores para a experiência do forte e suave que caracterizam o yin/yang, anima/animus que vivemos cotidianamente entre uma e outra força, ressaltando ainda seu aspecto complementar; uma existe diretamente em relação à outra.

\footnotetext{
${ }^{274}$ Professora de Teatro e responsável pela biblioteca e arquivos do Odin Teatret desde 2004.

${ }^{275}$ Tradução nossa. Original: "Non dimenticate mai che durante lo stop il peso sta sempre su una sola gamba, mai nel mezzo e mai su tutte e due. È importante che nel momento dello stop nella danza, L'azione non muoia dentro di voi. Quando vi fermate la tensione non deve scomparire dal corpo. Inserire uno stop non significa fermarsi e mettersi 'in posizione1. La posizione è vuota perchè in essa l'intenzione muore. Lo 'stomaco', invece, non deve morire mai. Vedo che molti di voi, preoccupati dallo stop, perdono la ricchezza e la bellezza delle immagini che avevano trovato con la danza." (apud RASMUSSEN, 2001, p. 20).

${ }^{276}$ Não exercitamos essa possibilidade na Odin Week -2013, somente mencionada por Rasmussen e conhecida por mim através dos treinamentos com Pedrosa e da literatura sobre esse tipo de treinamento, como p. ex. nos livros de Mariz e Ferracini.
} 
O slow motion (câmera lenta) é exemplificado por ela como um andar de astronauta, no qual o ator desloca-se pelo espaço como sem gravidade, em movimentos fluidos e lentos, podendo exercitar as oposições e ocultar as segmentações de uma ação para outra.

Fora do equilíbrio usa a inércia do peso ao sair do eixo para, antes de cair no chão, conter a queda e redirecionar a energia para lançar algo no espaço. No vídeo The transparente body ${ }^{277}$, Rasmussen explica que chegou a esse exercício pensando em como perder o equilíbrio e não cair sobre os joelhos, machucando-os. A partir daí, a forma de conter o desequilíbrio foi reter a energia da queda, bloqueando-a e criando a possibilidade de guiá-la e a transformar em outra ação, como a de lançar, mudando de direção e reestruturando a energia contida em uma continuação das ações.

Green energy $y^{278}$ (mais conhecido como green ou "verde"), executada em duplas, consiste em envolver uma faixa na altura do quadril do par, posicionando-se atrás dela e provocar uma resistência ao deslocamento ${ }^{279}$. Devem-se manter os joelhos flexionados, evitar a oscilação de altura, ou seja, caminhar como se submetido a um teto sobre a cabeça, e não deixar o tronco ir para frente, mantendo-o ereto. Neste exercício, retirei-me um pouco para observar e pude constatar uma recorrência de má compreensão que acontece no andar, ou melhor, no pisar no chão. Em geral, os atores observados apoiavam primeiramente a ponta dos pés ou o deslocam inteiro, sem articular; também é constante verificar tensões nas bocas e mãos, apertando-as ou as torcendo durante os deslocamentos.

Para a montagem de uma sequência de ações, Rasmussen orientou os três exercícios a seguir:

- Com a faixa de tecido, ainda em duplas, trabalhar como um cabo-de-guerra em três direções diferentes. Depois fazer a mesma coisa sem a faixa, mantendo a mesma energia.

- Trabalhar com o parceiro formas diferentes de empurrar um corpo contra o outro e depois reproduzir mantendo uma pequena distância entre os corpos, sem perder as

277 Odin Teatret Film \& CTLS Film Archives. Claudio Colbert, 2002. A partir dos 19:55min. Cf. também Il Ponte dei Venti. Un'esperienza di pedagogia teatrale com Iben Nagel Rasmussen. Copenhagen: F. Hendriksens Eftf., 2001 , p. 3.

\footnotetext{
${ }^{278}$ Rasmussen conta que esse nome foi dado ao exercício porque usaram faixas de tecido dessa cor, na primeira vez que o executaram. Informação oral. Odin Week, Holstebro, 2013.

279 A figura 25 corresponde também a esse exercício com a diferença que, ao invés das mãos do parceiro exercerem a contenção do quadril, usa-se uma faixa.
} 
qualidades encontradas no contato real. A partir daí, selecionar três formas de "empurrar-se" que farão parte da construção da partitura posterior com mais elementos trabalhados.

- Achar três formas de abraçar o colega e realizar a ação a novamente a uma pequena distância. É importante sempre manter a energia da ação "real”.

Depois de testadas as três ações de cada exercício, pode-se organizar as nove ações encontradas em uma sequência, mesclando a ordem de aparição de cada ação. Após memorizar a partitura, trabalhar com gradações de execução como a 50\% e 10\%. Rasmussen salienta que o $100 \%$ das ações tende a ser exagerado, principalmente no movimento dos braços, tirando a força do torso. Por fim, coloca-se um texto sussurrado, mas audível, a fim de estabelecer um diálogo entre palavras e ações.

Rasmussen indica a importância de achar as transições entre uma ação e outra, trabalhando também nessa ligação de forma que fiquem orgânicas. Uma preocupação, após decorar a partitura, é que não se tornem movimentos automáticos, mas sempre ações reatualizadas pelo momento do presente fazer. Segundo sua experiência, os exercícios feitos no treinamento colorem a atuação e, esse tipo de abordagem, colocando o texto depois, livra o ator da ilustração do mesmo.

Em sua pedagogia há sempre a orientação para que o ator descubra certa liberdade dentro do treino. Trabalhará com tarefas simples no início que o ajudem a encontrar a fluidez nas passagens entre os exercícios e a não interromper o fluxo (2006, p. 204-205). No vídeo já citado podemos ver um trecho de seu treinamento com membros do Ponte dos Ventos em que, ao seu comando, sem parar, os atores passam de um ao outro, mudando as qualidades e organizando a energia conforme a proposta dinâmica de cada exercício. Aliás, energia é uma palavra da qual Rasmussen se apropriou, segundo ela (2001, p. 10), por ser de fácil compreensão em todas as línguas e por não conhecer outra que melhor se adeque às distintas variações que observava na presença do ator após a realização de cada tipo de exercício.

A atriz Sandra Pasini, ${ }^{280}$ também membro do Ponte dos Ventos desde 1993, em seu artigo Come l'aqua nel deserto (Como água no deserto) registrou, durante um exercício de

\footnotetext{
280 Atriz italiana e cofundadora do Teatret $\mathrm{Om}$, atualmente sediado na Dinamarca, em uma cidade a quarenta minutos de Holstebro. Durante o Festuge, em 2014, tive a grata oportunidade de conhecê-la, bem como às outras artistas do $\mathrm{Om}$, a cenógrafa Antonella Diana (ITA) e Annemarie Waagepetersen (DK), música e atriz, e assistir à sua última produção com direção de Ana Woolf, I Maltagliati ( $O$ Malcortado, em livre tradução). Mais informações disponíveis em: <http://www.teatretom.dk/en>. Acesso em: 28/06/2014.
} 
escrita pedido pela atriz, um rico resumo de seus ensinamentos (apud RASMUSSEN, 2001, p. 57):

[...] Iben nos pede para escrever o que um ator tem que fazer, uma espécie de Dez Mandamentos do ator e, primeiramente, escrevê-los individualmente e depois em grupo.

Eu escrevo:

- Você não deve esquecer suas mãos e pés

- Não creia que sabe, mas que você aprendeu

- Não tem que sentir a solidão no trabalho como uma fraqueza, mas como uma força.

- Não deve chegar atrasado à sala [de trabalho]

- Não deve responsabilizar outra pessoa por seu treinamento diário

- Não deve descuidar de sua saúde.

Quando nos reunimos como um grupo [...] decidimos [...] dividir em quatro partes nossos Dez Mandamentos: Técnica Ética Disciplina Filosofia.

Disciplina:

- Você tem que ser responsável por sua saúde, pela pontualidade, pelo espaço e materiais de trabalho.

Ética:

- Não deve perder o sentido de solidariedade e respeito pelo trabalho dos companheiros

- Não deve se deixar abater pela fadiga, medo e problemas pessoais.

Técnica:

- Você não deve perder o controle, a precisão e ritmo da direção dos olhos, do corpo, da voz, respiração, do peso, equilíbrio, da tensão

- Você deve dançar só com o corpo, mas também com o espírito

- Não deve desperdiçar a energia ou fazê-la prisioneira.

Filosofia:

- Não se esqueça de ser uma criança.

- Não pense que você sabe, mas você aprendeu

- Você nunca deve considerar a sua pesquisa acabada. ${ }^{281}$

\subsubsection{Tradição Jan Ferslev}

Jan Ferslev apresenta-se, na demonstração de trabalho durante a Odin Week (25/08/2014) primeiramente como músico, que teve como mestre o Blues - e que então se tornou ator. Seu trabalho inicial no Odin Teatret foi naquela função, em 1987, na Itália. Depois foi à Dinamarca como professor de música e juntou-se ao ensemble, permanecendo até a atualidade. Compôs várias músicas para os espetáculos e uma estratégia de seu treino pessoal é tocar as mesmas músicas de formas diferentes. Como performer, o treinamento físico e as variações nas maneiras de tocar não lhe eram suficientes, então, começou a construir instrumentos a partir de objetos inusitados, como uma pá e uma corda, um pequeno violão que está disfarçado de boneco (usado em Kaosmos) ou um casco de tatu que virou um

${ }^{281}$ Tradução nossa. Respeitamos a pontuação encontrada no original. 
violão (Mythos). Esses instrumentos inusitados também o levaram à pesquisa de diversas formas de aproximação e manuseio dos objetos, testando possibilidades ao atribuir funções diferentes a eles. Ferslev apoia-se nos sons, tanto no que eles despertam, como uma vontade de dançar, quanto em ações provocadas pela "voz do instrumento" para compor suas partituras. Com isso, chegou a reduções em que "canta sem cantar e dança sem dançar" a partir da exploração de composições entre formas de andar, de intenções diferentes para a mesma partitura e de coordenar o significado de cada som com o contexto ou antepô-lo como contraponto.

A oficina de Ferslev, cursada em Holstebro e em São Paulo, chama-se A presença do performer (The presence of the performer) e é dirigida a atores e músicos que trabalham com teatro. Abaixo, isolamos alguns procedimentos. Como em todas as tradições, o ator deve ter um texto decorado, que saiba sem hesitação.

A partir de uma postura básica, joelhos semiflexionados e braços com espaço entre o corpo, andar pelo espaço empurrando o ar. Feslev salienta, como Varley, que, ao parar, nunca se deve ficar com o peso distribuído igualmente entre as pernas, pois essa é uma postura inorgânica.

Na prática de Ferslev, as ações são orientadas por tarefas, como:

1. Realizar três gestos;

2. Realizar três ações com braços, mãos;

3. Realizar três ações com os pés;

4. Realizar três formas de desequilibrar-se;

5. Realizar três reações.

Após achar as ações, interligá-las na sequência de uma partitura física, percebendo as suas fases divididas em: preparação, retenção, realização, finalização. Devem-se acrescentar ainda microações com os dedos das mãos, criando pequenas diferenças entre eles. Ferslev fala sobre o trabalho com as ações e a importância das fases de sua sucessão, evidenciando a necessidade de precisão: 
Tem que ter uma imagem clara do que você quer fazer, do que está fazendo no momento de preparação, para entrar neste momento cheio de energia antes de fazer o que Barba chama sats - e daí, [realizar] uma ação com resistência e a finalização, para criar a forma da ação. Porque se não [passar por essas fases] é como se socasse o ar, não tem resistência e nunca acaba. Mas, por exemplo, se você bate na parede, bate em alguma coisa, a ação tem um fim e tem resistência. ${ }^{282}$

Também vai diferenciar ações de meros movimentos,

\begin{abstract}
Movimentos são decoração, sem informação; ações são movimentos com informação, com uma ideia. É outra coisa quando você tem esta ideia de que está fazendo uma coisa precisa. Você pode elaborar, absorver, fazer só um pouquinho ou muito forte, enquanto o movimento é só movimento. Não trabalhamos com movimentos, tudo o que fazemos tem informação; são ações [...] que têm precisão e intenção, o porquê [...], a motivação, e isto é importante. ${ }^{283}$
\end{abstract}

O trabalho com voz e texto segue a orientação dos ressonadores, experimentando frases do texto em cada um. Ao acrescentar o texto às ações da partitura física criada anteriormente, trabalhar com as qualidades achadas nas experimentações, escolhendo os ritmos e tipos de emissão da partitura vocal.

Para Ferslev, o olhar cria espaços ao focalizar pontos escolhidos durante a execução da partitura. Uma possibilidade para criar surpresas no espectador é não olhar na mesma direção para a qual a ação se dirige.

Uma de suas orientações, que considero particularmente eficiente é: "Ache a justificativa para o que está fazendo." 284 Essa pode ser interna, mas também significa adequar as ações ao texto, por exemplo, reduzindo ou ressignificando a ação conforme a montagem junto à fala.

Ferslev orienta também variações de tamanho e intensidade (tudo a 50\%, 10\%, por exemplo); ritmo; aplicação de omissão (ex. realizar a partitura completa estando sentado, só com os olhos etc.). Essas possibilidades permitem ao ator "jogar" com diversas dinâmicas em suas ações, criando variações na construção das cenas.

\footnotetext{
${ }^{282}$ Entrevista gravada em vídeo, concedida pelo ator a mim por ocasião de seu curso realizado na USP, em São Paulo. 29/10/2013.

${ }^{283}$ Idem.

${ }^{284}$ Anotação pessoal, workshop A presença do performer, ECA-USP, 27/10/2013.
} 


\subsubsection{Tradição Tage Larsen}

A oficina cursada com Larsen é intensa e o trabalho ininterrupto. Envolve interação como mote para as experimentações e aplicação dos princípios e promove troca de vocabulário corporal entre os participantes. Larsen também associa a voz aos exercícios, procurando sempre variações entre sons e formas de dizer o texto. Durante o aquecimento nos conta que no início de seu treinamento "descobriu que as estátuas têm vida",285 e, a partir das formas, pesquisou os impulsos internos e transições orgânicas de uma para outra. ${ }^{286}$

1. Aquecimento em roda, cada um propõe um movimento, todos copiam.

2. Andando/movimentando-se pelo espaço a fim de aquecer todas as articulações

3. Floating (em tradução livre, flutuando). Esse será a base entre todos os outros comandos. É uma forma de deslocamento ininterrupta pelo espaço, mantendo os joelhos semiflexionados e mudando de direção e ritmo. O floating manterá todos em movimento enquanto os outros exercícios acontecem.

4. Escolher cinco cumprimentos (podem ser só gestos, mas também podem ter sons ou palavras) e trocá-los com as pessoas que encontrar pelo caminho.

5. Aleatoriamente, um dos participantes pode dar os seguintes comandos, que, ao serem proferidos, ${ }^{287}$ são executados pelo propositor e depois copiados por todos:

- Jump (saltar);

- Down ("para baixo"). Ir para o chão com uma forma final definida;

- Bronze. ${ }^{288}$ Fazer alguém perder o equilíbrio;

\footnotetext{
${ }^{285}$ Anotação pessoal, Odin Week, Holstebro, 24/08/2013.
}

${ }^{286}$ Na peça Dentro do Esqueleto da Baleia Larsen contou-nos que foi incluído posteriormente, portanto já com a dramaturgia pronta e o espetáculo ensaiado. A solução cênica foi uma personagem que atravessa longitudinalmente a cena, executando ações com uma pequena peça de madeira retangular. Anotação pessoal, Odin Week, 24/08/2013. Assistindo à peça, vi claramente a inspiração nas "estátuas com vida" a que ele se refere. Por vezes a imobilidade que assume é tão ativa que, a meu ver, desperta mais atenção do que as cenas "em movimento" que acontecem simultaneamente com outros atores. Também achei referência em BARBA, 2010b, p. 157,158, em que o diretor comenta o efeito da ação de Larsen, aparentemente desconectada das outras, que provoca ressonância ou contraponto às outras cenas e causa subversão ou estupor no final da peça quando se revela o sentido de sua presença no todo.

${ }^{287}$ Uma “dica” de Larsen, para os grupos muito grandes, é que o propositor chame com o comando até todos entenderem e olharem para ele, e só então, execute a ação.

${ }^{288}$ Perguntei a Larsen por que nomeou como Bronze a esse exercício. Sua resposta foi que é um material com o qual se faz esculturas, assim como o mármore (marble), mas que é só um nome, poderia ser plástico, talvez. Informação oral, Festuge, Holstebro, 15/06/2014. É interessante a atitude cética desse ator sobre o interesse que o grupo e o próprio trabalho despertam. Quando falei que estava escrevendo sobre seus procedimentos e que era 
- Marble (literalmente, mármore). Executar uma forma, como uma estátua;

- Turn (giro). O giro deve ser executado de forma contínua pelo proponente e os outros o copiam até ele parar.

- Help (ajuda). Desequilíbrio, a partir de algum ponto do corpo, com forma final definida. Nesse comando, quem o profere inicia seu desequilíbrio e quem estiver perto vem sustentá-lo. Se não der tempo de segurar a pessoa, a forma final definida significa que ela não deve "despencar" no chão, mas achar o equilíbrio no último instante, como no exercício fora do equilíbrio de Rasmussen, por exemplo.

- Play (brincar). Quem dá esse comando, deve falar um texto, dividido em três partes e com três formas diferentes de dizê-lo, portanto o proponente falará três vezes seguidas e depois o grupo copia as propostas. Ex.: a) Esta porta/ b) é / c) um erro ${ }^{289}$. Pode ser dito na primeira vez como a) = ressonador da cabeça; b) = ressonador do ventre; $c$ ) = ressonador do peito. Nas outras duas, mudar os ressonadores, criando diferentes formas de falar o mesmo texto.

- Let's go (em tradução livre: "vamos lá!”). Propor três comandos, como jump, turn, down com diferentes formas de realizá-los e incluindo sons, um para cada um deles. Procurar diferentes contagens, p. ex. $1^{\circ}$ comando $=$ três saltos, $2^{\circ}$ comando $=$ um giro, $3^{\circ}$ comando $=$ duas formas de sentar.

- Durante o floating, quando encontrar alguém, propõem-se algum dos comandos, realizando um trabalho em dupla, sendo que bronze e let's go sempre devem ser dirigidos ao grupo todo.

6. Transferência de peso e impulso.* Segundo Larsen: "Suporting and being throwing" 290 (Amparando e sendo jogado). Em duplas, uma pessoa deve apoiar um pé sobre a coxa do parceiro. Após testarem os apoios, quem está na base dá o impulso para a outra pessoa pular para trás; manter olho no olho. Quem dá o impulso, lança uma palavra também. Congelar as posturas finais, observar, seguir no floating pelo espaço.

\footnotetext{
importante, para mim, aquela informação, sua reação foi: "Really? Why?"(em livre tradução: "Sério? Por quê?"). Idem. Posteriormente, durante o festival, mostrei a descrição que estava fazendo de sua oficina. Disseme: "Ah, então é isso que você está fazendo?! Eu sempre fui um pouco preguiçoso para escrever." Preocupou-se principalmente com o entendimento dos exercícios por quem vai ler e discutimos alguns nomes mais adequados para os mesmos.

${ }^{289}$ Exemplo dado por Larsen. Original "This door is a mistake". Frase de Mythos - ritual para o século breve (1998), espetáculo do Odin Teatret.

${ }^{290}$ Definição do ator durante o Festuge - 2014, quando mostrei a ele o desenho do exercício.
} 


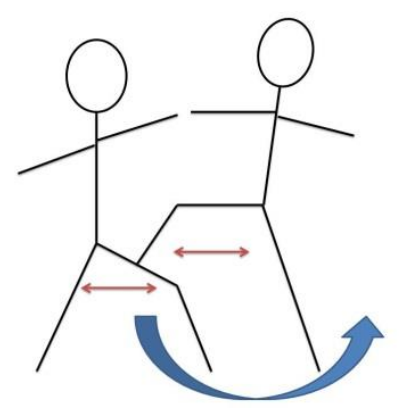

Figura 26. Transferência de peso e impulso ou Suporting and being throwing.

7. Hook (gancho). Em dupla, quem propõe o hook, bate no seu próprio pé para convocar o parceiro. Com os pés enganchados, quem propôs deve girar no seu eixo até lançar a pessoa para trás. Quem é girado deve cantar uma música.

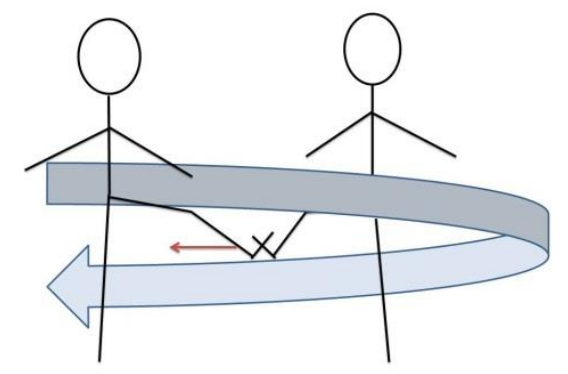

Figura 27. Hook.

8. Desequilíbrio com giro.* Larsen fala que esse é um exercício de confiança. Consiste em pegar uma pessoa por trás, suspendendo-a e girar com ela. Ao depositá-la no chão, procurar seu olhar e se despedir dela, em silêncio.

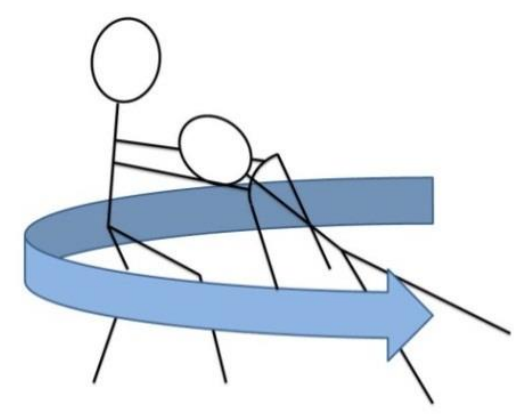

Figura 28. Desequilíbrio com giro.

9. Gangorra.* Nas palavras de Larsen: "Up and down and sitting on the floor from side to side ${ }^{, 291}$; ou seja: "Para cima e para baixo e sentando no chão, de lado a

${ }^{291}$ Outra definição do ator durante o Festuge - 2014, quando mostrei a ele o desenho do exercício. 
lado". Em duplas, olhando-se nos olhos, dar as mãos e testar o equilíbrio, levantando e sentando, até que uma pessoa é "lançada" para trás pelo impulso do outro. Sempre sem perder o contato visual, achando formas de encontro mesmo depois do lançamento até decidirem a finalização tácita do exercício.

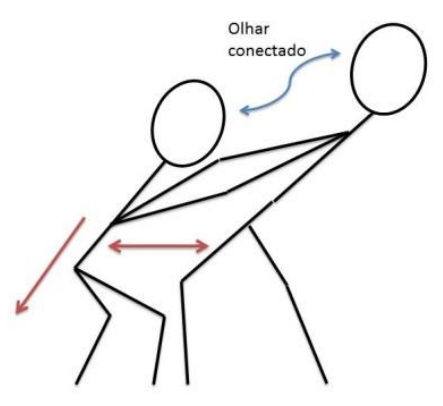

Figura 29. Gangorra ou Up and down and sitting on the floor from side to side.

Em todos os exercícios, Larsen ressalta que a coluna deve estar sempre comprometida, pois é daí que nascem os movimentos. No uso da voz orienta para trabalharmos com ela aberta/alta, porém modulando-a em variações. Salienta que é preciso ter precisão no que se quer de forma a deixar claro, para si e para os outros, o que se está fazendo.

\subsubsection{Tradição Kai Bredholt}

Durante a Odin Week, Bredholt abria as manhãs com um aquecimento físico composto de exercícios do Hatha Yoga ${ }^{292}$ para em seguida comandar uma corrida nos arredores da sede, na qual ao mesmo tempo, cantava-se. Era o Running and singing ou Jogging and singing (Correndo e cantando). Segundo ele, essa foi uma descoberta que o ajudou a dominar a voz e "baixá-la" do peito, pois, para manter o fôlego na realização das duas ações simultâneas, o abdômen e o diafragma devem ser acionados. Durante o percurso, repetíamos as frases de uma canção em inglês, uma a uma, que ele nos ensinava para logo passar a cantar trechos maiores, que repetíamos também. Depois de uma grande volta pela paisagem do entorno, retornávamos à sede, sempre cantando e correndo, até finalizar com uma coreografia e outra

\footnotetext{
${ }^{292}$ Basicamente alongamentos e respirações dessa técnica, incluindo a "Saudação ao sol".
} 
canção dinamarquesa no pátio, ainda fora do prédio central. ${ }^{293}$ Entre o aquecimento, a corrida e finalização a atividade durava uma hora.

Em entrevista com o ator, ${ }^{294}$ ficam claras as estratégias muito pragmáticas como a corrida para focarmo-nos no momento presente, no que se está fazendo. Sobre essa atividade dirá:

É ótimo para entender muitas coisas e funciona! [...] funciona em muitos princípios: condiciona fisicamente, na fisiologia [da voz] por que a pessoa já canta com os ajustes; ela já tem que cantar para fora. E funciona muito para focar: agora estamos fazendo isto. E isso tira toda a preocupação estética com o canto. Não importa se é bonito ou não, não é isto. Agora é: tem que ter o instrumento forte, depois se pode trabalhar com ele.

Depois dessa abordagem, em suas oficinas, diz Bredholt que entra nas construções de materiais vocais e físicos, seguindo os princípios da montagem de partituras, ressaltando que o fascina ensinar às pessoas que qualquer material pode ser aproveitado, desde que o ator se dedique à pesquisa dos detalhes, na profundidade que eles podem atingir através do conhecimento sobre o que se está fazendo. E ao dominar totalmente sua partitura, colocar-se obstáculos para manter vivo o próprio interesse no trabalho. ${ }^{295} \mathrm{Na}$ entrevista já citada, Berdholt mostrou-se muito receptivo a todo tipo de intercâmbio com outras técnicas, a favor da formação do ator. Citou o parkour, o boxe, a dança contemporânea, como agregadores potenciais do trabalho para o ator, desde que não sejam apenas condicionamento físico ou exibição de virtuosismo. Explica que, por conterem os princípios, esportes ou técnicas corporais, se trabalhadas no contexto da criação de partituras, significando as ações e atentando aos detalhes, servem como suporte para o ator na aplicação criativa.

Na primeira estadia em Holstebro ainda soubemos que Bredholt é responsável pelos Barter e sua tradição envolve muitas vezes o contato direto com o público. Na organização desses eventos, ao lidar com os potenciais participantes provoca: "O que você sabe fazer melhor? Então mostre”. Conta que por vezes a pessoa diz que não sabe fazer nada, ou não quer demonstrar suas habilidades, mas traz um parente que sabe cantar ou um amigo que sabe dançar e que a desculpa de trazer alguma coisa para mostrar é interessante para as pessoas se

\footnotetext{
${ }^{293}$ Devido a problemas nos meus joelhos e ao terreno relativamente acidentado do percurso, pratiquei a corrida somente por dois dias. Em outros, juntava-me ao grupo na fase final, durante a dança no pátio.

${ }^{294}$ Entrevista concedida a mim por ocasião da visita do grupo a São Paulo em tournée do espetáculo A Vida Crônica. 03/11/2013.

${ }^{295}$ Idem.
} 
aproximarem do teatro. Uma experiência emblemática para ele, no aspecto de socialização que esse tipo de atividade pode promover, foi quando preparou o número do coral do corpo policial de Holstebro e o levou para cantar em uma escola de línguas que abrigava muitos imigrantes, quiçá, alguns ilegais. A interação entre a apresentação e os espectadores gerou aproximação empática dos oficiais com aquelas pessoas e por outro lado admiração e simpatia dos espectadores pela exposição a que os policiais estavam se submetendo em uma apresentação artística. ${ }^{296}$

Na apresentação do Barter na Odin Week, Bredholt tocou, dançou e coordenou cerca de cento e cinquenta pessoas que se apresentavam para convidados da cidade, e umas para as outras, sem ensaio prévio. Seu comando sobre os grupos e sucessão das cenas é calmo e assertivo, mas também vigoroso e animado. Para os atores participantes, esse tipo de atividade gera uma escuta qualificada, atenção redobrada e abertura ímpar para os acontecimentos.

Já na organização de apresentações em espaços fora do teatro, ele traça estratégias de aproximação do ator com o espectador e quebras que visam manter um "estranhamento" e interesse nas ações. Preocupa-se também com o direcionamento do foco de atenção dos espectadores, estabelecendo, por meio de ações mais expansivas ou chamamentos com recursos vocais, p. ex. um canto, uma palavra de ordem, a sequência dos acontecimentos. Ricardo Puccetti, integrante do Lume, destaca os aspectos técnicos do trabalho de Bredholt, observados por ocasião de sua direção do espetáculo Parada de rua junto ao grupo, sendo a “teatralização de espaços não convencionais, música e ação física, uso de instrumentos musicais e corporeidade; a construção de cenas a partir da relação música-espaço-corpo". ${ }^{297}$ Suzi Frankl Sperber, em artigo sobre o mesmo trabalho, também traz elementos das estratégias de Bredholt para manejar situações de espetáculo fora do teatro:

Segundo Kai Bredholt, afora dominar um instrumento e cantar, o ator da parada precisa também aprender e praticar o caminhar. É algo mais complexo do que se possa imaginar: depende de técnicas de mudança da cena com instrumentos; é preciso mexer-se sem ruído. É preciso coordenar o domínio do instrumento, a atenção ao público, a fím de atraí-lo, eventualmente individualmente. Para isto existe a marcação dos movimentos, a atenção às indicações bastante sutis do ator que puxa o pequeno cortejo. Há seqüências (sic) fixas que funcionam para todos. Mas há também variações que dependem de circunstâncias imprevisíveis e que,

\footnotetext{
${ }^{296}$ Anotações pessoais, Odin Week, Holstebro, 23/08/2013.

${ }^{297}$ In: Revista do Lume, $\mathrm{n}^{\circ} 4,2002$, p. 81.
} 
contudo, precisam ser aproveitadas. É fundamental construir, na cena, pequenas mudanças, com histórias relacionadas ao lugar em que o grupo vai estar. ${ }^{298}$

Presenciamos também algumas apresentações de rua durante o Festuge, em que Bredholt coordenou as ações em cena, com grupos de músicos, atores, clowns, cavaleiros e dançarinos, além dele próprio, em diversos site-especifics como alamedas comerciais de Holstebro ou no rio e entorno da mesma cidade.

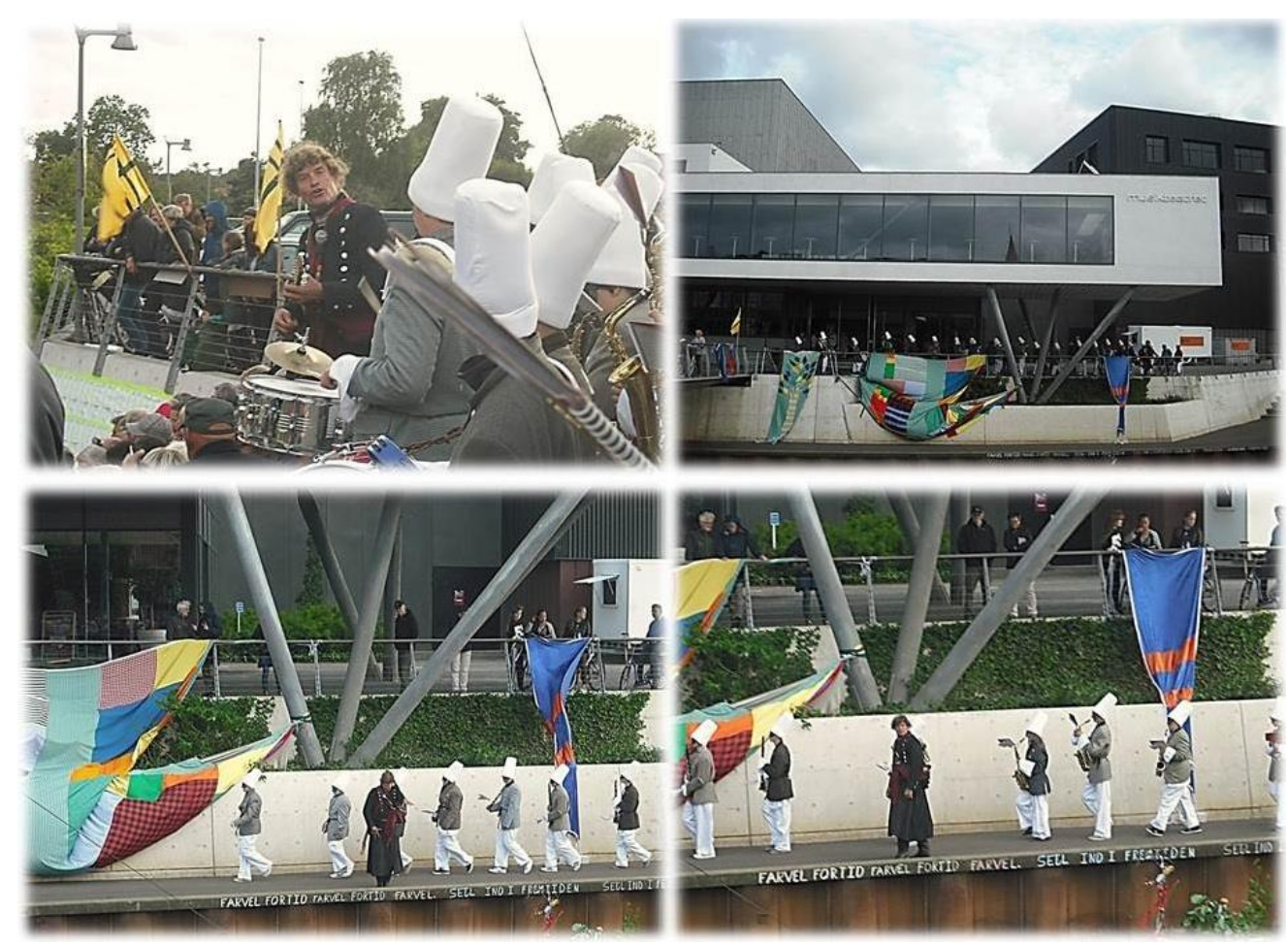

Figura 30. Kai Bredholt em apresentação de rua. Festuge, 2014. Holstebro, Dinamarca. Fotos e montagem: Leticia Olivares

\subsubsection{Tradição Frans Winther}

Winther coloca-se essencialmente como um músico e trabalhará conosco na sua oficina, que se chama A Composer's Tradition (Tradição de um compositor), técnicas vocais e improvisações, que envolvem também palavras e poemas musicados. No aquecimento do corpo e voz, com o grupo em roda, primeiramente "sacudir" o corpo, soltando articulações e

${ }^{298}$ In: Revista do Lume, $\mathrm{n}^{\circ} 4,2002$, p. 58. 
deixando o som sair naturalmente e depois permitir criações de sons com a voz e o corpo, por meio de diversas formas de palmas ou embocaduras diferentes. Há um trabalho de controle respiratório e emissão vocal, no qual, a mão, a partir dos lábios, desloca-se para frente junto com a expiração e volta com a inspiração, adicionando sons no seu desenrolar. Compartilhamos também sons e formas de emiti-los passando para o colega ao lado, até que a roda toda fizesse a proposta. ${ }^{299}$

Durante a Odin Week, junto a Bredholt, Winther foi o responsável pelo Barter do qual participaríamos, que incluía canções e cenas selecionadas dos participantes e uma composição do próprio Winther para a ocasião. Esse Barter aconteceu no último dia do evento, em uma troca com uma casa de idosos e uma escola pré-primária locais, que também apresentaram seus números para nós. Trabalhamos com Winther, então, a apresentação da parte musical, composta por um canto coral, com poemas e canções selecionados por ele a partir de materiais com esses conteúdos, entregues a seu pedido no segundo dia de sua oficina. Ao serem inseridos no contexto musical, Winther dirigiu improvisações com dinâmicas corporais como juntar e separar o coro, abaixar e levantar no espaço, dando destaque para alguns solistas que dançavam e/ou cantavam entre o grupo.

Winther trabalha com a orquestração do coro, salientando as possibilidades de pesquisa das formas melódicas e/ou decompostas de proferir palavras ou frases das músicas ou poemas. Seus procedimentos envolvem a dramaturgia sonora das ações, agregando instrumentos musicais e transformações dos ritmos ou formas de cantar/falar aquelas.

No trabalho de montagem entre as ações físicas e a fala/canto, sua orientação é de quebrar o ritmo conhecido ou esperado e também criar interrupções que possam mudar a percepção do espectador.

Em um artigo sobre o trabalho com a voz no grupo, destaca:

O uso de vozes é particularmente interessante; o Odin tem desenvolvido uma série de técnicas, que vão desde acordes na fronteira com canto lírico clássico até gritos de aves, sussurros e sons guturais, que atendem a necessidade de criar um universo

\footnotetext{
${ }^{299}$ Achamos registros de um workshop ministrado por Winther (The Breath of Fire - 2010) no Youtube, com mais de 20 vídeos sobre de seis dias de oficina. Como exemplo do exercício respiratório com emissão vocal descrito, verificar no seguinte endereço: 〈http://youtu.be/mvZLVY7jBJc〉, Third session (from breathing to rythms). Acesso em 08/06/2014.
} 
sonoro único; um universo que pode invocar a imagem de beleza ou terror, e que, por assim dizer, é a voz pessoal do teatro. ${ }^{300}$

Winther $(2000$, p. 85, 86) explica como são os processos com a música no Odin Teatret:

1. A música do ator que é desenhada no seu próprio trabalho com a voz, o corpo e os requisitos do palco. São improvisações dos atores em partituras acústicas que podem formar uma música ou fragmentos de música, temas rítmicos, uma matriz sonora ou uma composição desses elementos. Essa partitura pode ser adaptada para uma performance específica durante os ensaios. Há colaboração do diretor, de outros atores, dos músicos e do compositor.

2. A música do músico. Segundo ele, uma melodia é improvisada e depois pode assumir sua forma final com auxílio de harmônicos ou uso de cordas. Ou uma sequência nas cordas pode formar a base de uma melodia. Pode acontecer em um processo coletivo, no qual um músico compõe os arranjos de cordas e outro cria uma ou mais melodias, produzindo um período musical. Também podem juntar harmônicos, novos arranjos para mudar alguma característica buscando tornar tudo mais interessante. Da mesma forma, trabalham com os elementos rítmicos.

3. A música do compositor. Winther salienta que frequentemente o compositor tem que trabalhar com um conjunto de informações que recebe, como a dramaturgia, por exemplo. Para escrever uma música que sirva àquele contexto, analisa com atenção o texto e testa a ideia musical espontânea que surge, anotando-a e a tocando no piano. Ressalta que o uso do computador possibilitou a produção de folhas legíveis e agilidade em transpor e escrever composições individuais. $\mathrm{O}$ compositor deve levar em conta a disposição dos espectadores, sentados dos dois lados com o "palco" ao centro, como é geralmente utilizado pelo Odin Teatret, e a proximidade variada com os atores. Por isso, há a preocupação com que todas as vozes tenham qualidade de uma primeira voz, já que, dependendo da proximidade com um ou outro ator, o espectador ouvirá de formas diferentes cada um e o todo.

\footnotetext{
300 Tradução nossa. Original: "The use of voices is especially interesting; Odin has developed a number of techniques, ranging from chords bordering on classical lyrical singing to bird's cries, whispering, and guttural sounds, which meet the need to create a unique sound universe; a universe which can invoke the image of beauty or terror, and which, so to speak, is the personal voice of the theatre." (Odin Teatret and the Music apud Odin Teatret 2000. Aarhus: Aarhus University Press, 2000. P. 85. ISBN 87-7288-872-5)
} 
4. A música do diretor é uma montagem de elementos, englobando as três dimensões acima mais músicas de diferentes países das quais o diretor tomou conhecimento e o inspiraram e que são capazes de "criar associações". Os atores têm que ensaiá-las e as adaptar para suas vozes. Também o compositor precisa trabalhar sobre os arranjos e os adaptar para o resto da trilha, possivelmente orquestrando-os.

\subsubsection{Tradição Else Marie Laukvik}

Laukvik não ministrou nenhum workshop durante a Odin Week de 2013. Porém, concedeu-me uma entrevista ${ }^{301}$ na qual conversamos sobre sua trajetória no grupo e percepções sobre o treinamento para o ator. Em seu gabinete de trabalho, localizado junto aos arquivos e também sala de registros fotográficos, contou-me sobre o quanto o treinamento do início do grupo marcou seu corpo em aspectos de precisão e no trabalho com ações concretas que lhe davam a sequência a seguir, porém procurou sempre espaço para improvisações a respeito de suas motivações, imagens internas e pequenas variações que a mantém viva em cena. Comenta: “A linguagem do ator é a linguagem do corpo; não é uma coisa telepática. A mensagem ter que ser passada de forma muito clara, mas às vezes [nas improvisações] não sabemos qual é a mensagem que sairá." ${ }^{302}$

Aponta que, no treinamento, indica ao ator deixar o rosto o mais neutro possível, para que não se apegue à vontade de expressar-se através de "caretas", mas sim deixar que o corpo fale por si. A atriz defende que o ator deve manter-se fiel também ao seu instinto, ter coragem de seguir o que sente. ${ }^{303}$ Uma das orientações que costuma dar em seus workshops, baseada nos pensamentos de Grotowski, é sobre a importância do processo, ao invés de focar no resultado já que esse será consequência daquele. Define o treinamento como uma plataforma que proporciona, além de certa diversão e prazer para o ator, a forma de obter materiais com os quais poderá trabalhar, combinando-os ou apenas seguindo o que o fazer está lhe oferecendo.

\footnotetext{
${ }^{301}$ Holstebro, 25/08/2013.

${ }^{302}$ Idem.

303 Também achamos correspondência a esses procedimentos em uma entrevista de Laukvik, disponível em: <http://www.odinteatretarchives.com/odinstory/video-else-marie-laukvik-2009>. Acesso em 08/06/2014.
} 
Segundo ela, como atores, nunca devemos começar a partir de emoções, e como diretores, nunca dizer a um ator "você tem que estar muito triste, você está muito aborrecido" porque tudo isso vem de "reações" às quais toma como "pontos de partida". Diz que para ter as reações é preciso levar em consideração todo seu treino, suas improvisações e ações. Nas improvisações, sugere que se comece a partir de movimentos deixando que eles produzam imagens que levam ao próximo movimento e assim sucessivamente, "como Tarzan na selva, você vai pulando de um para outro cipó até criar um tema preciso em sua cabeça. Daí você tem que fixar tudo isso." 304 Comenta que o ritmo, achar o tempo certo das ações é muito importante para a atuação, pois às vezes nota que o nervosismo de uma atriz pode fazê-la acelerar suas ações ou, quando se sente muito segura e está se satisfazendo com sua atuação, torna tudo lento ou faz a mais do que é necessário.

Sobre a rigidez das partituras nota que apesar de ser possível segui-las tecnicamente todas as vezes que as realiza, as mudanças de motivação internas podem trazer novas nuances, mantendo-a interessada no que está fazendo (1993 p. 167). Laukvik reflete sobre seu trabalho como artista:

Eu sou uma jogadora, uma apostadora que gosta do jogo por causa da constante busca de novas soluções e novos caminhos que levam de um para o outro. No processo criativo eu jogo inventando novos jogos e buscando todas as soluções possíveis, antes de finalmente fazer a minha escolha, tanto como diretora e atriz. Enquanto no processo de atuação de eu construo um conjunto completo de regras e eu estou limitada pela pontuação fixa e pela interação com os outros jogadores. No entanto, não posso impedir-me de criar novos jogos quando guiada por um envolvimento total. [...] Não há sinais de "Entrada Proibida", apenas problemas para resolver. $^{305}$

Conversamos também sobre o que pode significar o talento para o ator, e a seu ver, salientando que no Odin Teatret Barba nunca procurou por "talento" e sim pela disponibilidade do ator "trabalhar duro e exercer a carpintaria do ofício", talento é a capacidade de usar seu know-how, as habilidades adquiridas, que podem sempre ser aprimoradas de novas formas. Ela fala da criatividade usada para pegar pequenos pedaços e os

\footnotetext{
${ }^{304}$ Entrevista concedida a mim, Holstebro, 25/08/2013.

305 "I am a player, a gambler who enjoys the play for the sake of constantly finding new solutions and new pathways that lead from one to the next. In the creative process I play inventing new games and seeking all possible solutions, before I finally make my choice, both as director and actress. Whilst in the performing process I build up a complete set of rules and I am limited by the fixed score and by the interaction with the other players. Nevertheless, I can't prevent myself from creating new games when driven by a total involvement. [...] There are no 'No trespassing' signs, only problems to solve." Do miracles happen? In: The open page. Holstebro: Odin Teatret Forlag, 1998. p. 25.
} 
rearranjar em outros modos de configuração. Exemplifica com aspectos das ciências, em que os cientistas muitas vezes partem de outros trabalhos e os combinam para chegar a um novo resultado.

Em vídeo, ${ }^{306}$ assisti à sua prática pedagógica que considera exercícios de retenção e expansão, pensando em termos de "energia" retida e solta no espaço através de ações de puxar e lançar. Ainda, treino de equilíbrio, slow motion, mudanças de direção e ritmo, saltos, transferência de peso, formas de andar, articulação de braços e pernas a partir da consciência da coluna vertebral e dos quadris. Algumas imagens de que se utiliza são "snake arms" e "snake legs" (braços-serpente e pernas-serpente, respectivamente em livre tradução); "amassar as uvas com os pés", passos do Katakhali e posturas da Commedia dell'arte, como a do Arlechinno e seus pequenos saltos no deslocamento.

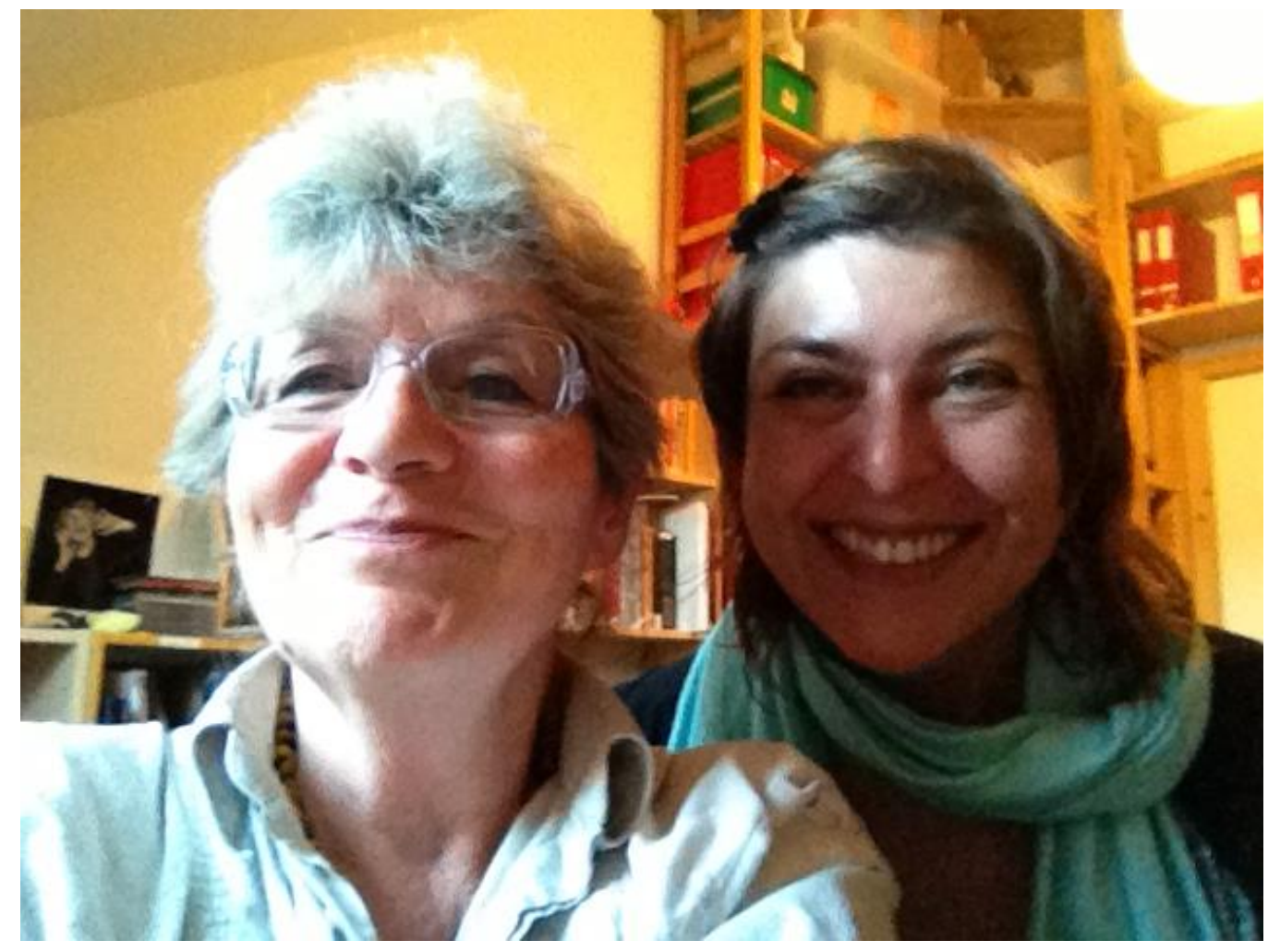

Figura 31. Else Marie e eu em seu escritório, após a entrevista. Holstebro, Dinamarca 25/08/2013. Foto: Else Marie Laukvik.

${ }^{306}$ Fragment's for Else Marie Laukvik's workshop - 2009. Odin Teatret Archives, Holstebro, 2010. Acesso ao vídeo durante a Odin Week, 25/08/2013. Disponível em:

<http://www.odinteatretarchives.com/odinstory/video-else-marie-laukvik-teaching-2009>. Acesso em 08/06/2014. 


\section{2 $O$ estado da arte: dramaturgia do ator}

O "estado da arte" diz respeito ao período de conformação dos materiais segundo a lógica de cada ator. Em todas as tradições acima, a aplicação da técnica nas criações se dá por improvisação, elaboração/composição, justaposição, intersecção, paralelismos, contrapontos na criação de partituras cênicas e vocais que vão ganhando camadas de significação em sua repetição e execução. Para o ator, nesse trabalho de composição das ações, os fragmentos vindos dos diversos materiais pesquisados devem achar o seu fluxo no reconhecimento da transição de uma ação para a outra e devem contar com diferentes ritmos, intensidades, tamanhos, velocidade, intenções, na configuração das partituras. Sua justa medida também deve ser alcançada em relação ao texto e as justificações internas e externas para as ações físicas e vocais. É claro que este é um trabalho repleto de tensões. O almejado fluxo passará por inúmeras intervenções dos próprios atores e do diretor na conformação para a encenação. Como já comentado em 1.3.3, nas mãos do diretor as montagens dos atores podem ser totalmente desconstruídas e ressignificadas. Porém, o que aprendemos com os atores do Odin Teatret é que, como intérpretes, podemos guardar as origens de nossas ações e as recuperar em segredo, sem evidenciar as motivações, mas como alimento para o próximo passo da personagem ou persona em cena. E achar, no rigor da estrutura da partitura e em sua repetição, a liberdade para estar pleno no momento presente. Dito desse modo, estamos no terreno do intangível, apesar de fazer muito sentido para quem já tem certa experiência no ofício. Mas, buscando a materialidade dos procedimentos, os atores do Odin Teatret dissecam suas cenas/encenações exibindo o que por eles foi decodificado do processo da passagem da técnica para a montagem e, dessa forma, mostrar também que "é possível”, como disse Varley

em $O$ Eco do Silêncio, ${ }^{307}$ depois de uma detalhada demonstração de seu trabalho com harmônicos.

Tomando os conceitos de partitura e subpartitura para abrir este tópico, em seguida fazemos um apanhado das anotações em diários sobre as demonstrações de trabalhos assistidas, procurando evidenciar os procedimentos adotados nas construções da dramaturgia de alguns dos atores do Odin Teatret.

\subsubsection{Partitura e subpartitura: precisão e transpassagens}

307 Apresentação em São Paulo, Centro Iyengar Yoga, 01/12/2012. 
$\mathrm{O}$ teatro, para arder, precisa da lenha: o corpo e a alma do ator. Eugenio Barba (2006, p.28)

Como nota Pavis ${ }^{308}$ (apud DE MARINIS, 1997, p. 63), a noção de partitura está presente na maioria dos registros de atores e diretores sobre o trabalho do ator, de Stanislavski à Barba. Essa noção diz respeito a uma notação técnica, a exemplo da feita em Música, de onde a nominação é emprestada, para tornar mais palpável a intangibilidade da arte do ator. Aplicada a ela e também à cena, ainda segundo Pavis, dota a reflexão sobre os modos de fazer do ator de uma base tangível, com as possibilidades de anotação, repetibilidade, armazenamento e técnica reconhecível, como a de uma música. O autor (apud DE MARINIS, 1997, p. 80) atribui a Grotowski, Barba, Vitez e Brook o aprofundamento teórico sobre a problemática partitura/subpartitura a partir da noção de que o ator não é tratado como "um portabandeira ou um portador do signo, mas como massa moldável em profundidade e trabalhada até o último detalhe na superfície."309

Para Stanislavski (Pavis apud DE MARINIS, 1997, p. 63), reputado por ter utilizado o termo pela primeira vez na aproximação com o fazer teatral, a partitura relaciona-se ao papel do ator e à representação como um todo. No que diz respeito à representação traduz cada participação envolvida na construção cênica da obra, a serviço do superobjetivo ${ }^{310}$ da peça. Para o ator, consiste na linha geral das ações, que podem ser subdivididas nas unidades da ação física, orquestrada pelo que o autor imaginou e previu na encenação de seu texto. Pavis ressalta que essa visão enfraquece a autonomia da representação e do ator. No entanto, ao

\footnotetext{
${ }^{308}$ Nesse texto, Pavis oferece uma pequena antologia do uso dessa noção a fim de proporcionar a confrontação entre afinidades e diferenças no seu uso por diversos pedagogos, diretores e encenadores. De Stanislavski, passando por Meyerhold, Vachtangov, Checov, Craig, Appia, Dalcroze, Copeau, Decroux, Artaud, Brecht, Grotovski, Barba, Vitez, Brook, Schechner e por fim, Robert Wilson, através de recortes de textos dos próprios ou relacionados a eles, a noção da partitura é retomada por cada um, apontando sua compreensão como instrumento para o ator e a encenação. Da Stanisllavskij a Wilson. Antologia portatile sulla partitura. In. DE MARINIS, Marco (org.) Drammaturgia Dell'Atore.. Bolonha: I Quaderni del Ballello Ebbro. Teatro Eurasiano n.3, 1997, p. 63-81. Pudemos comparar nossa tradução para do italiano na fonte consultada o português com a de Paolo Dodet usada na dissertação de Monica Siedler, que, generosamente, compartilhou esse material. As traduções, então, são permeadas por, e confrontadas entre, a minha versão e a desse tradutor.

${ }^{309}$ Tradução nossa. Original: "[l'attore vi] è trattato non come un portabandiera o un portatore di segni, ma come pasta plasmabile in profondità e lavorata fino agli ultimi dettagli in superfície."

${ }^{310}$ Termo usado por Stanislavski para se referir aos elementos constitutivos de uma peça, englobando todos os seus aspectos e a serviço da obra do autor. Cf. STANISLAVSKI, 1998, p. 365.
} 
tomar a partitura como um plano de trabalho sobre a personagem, esclarece passo a passo a contribuição para a realização do todo, ou seja, a encenação. ${ }^{311}$

A abordagem de Grotowski sobre a partitura evidencia os aspectos físicos da sequência de ações que o ator deve seguir, salientando a conquista da artificialidade como recurso. Essa noção propiciará, paradoxalmente, o reconhecimento do "processo espiritual", facilitando, na estrutura formal estabelecida, a sua manifestação. Diz Grotowski (2011, p.14; $31)^{312}$

Descobrimos que a composição artificial, além de não limitar o processo espiritual, na verdade nos leva até ele. (A tensão tropística entre o processo interior e a forma fortalece ambos. A forma é como uma isca, à qual o processo espiritual responde espontaneamente e contra a qual ele se debate). As formas do comportamento "natural" comum obscurecem a verdade. Compomos um papel como um sistema de signos para demonstrar aquilo que está atrás da máscara da visão comum: a dialética do comportamento humano.

[...]

Por sua vez, essa pesquisa da artificialidade requer uma série de exercícios adicionais, formando uma partitura em miniatura para cada parte do corpo. Seja como for, o princípio fundamental é o seguinte: quanto mais absorvidos nos tornamos pelo que estiver escondido dentro de nós, no excesso, no desnudamento, no mergulho interior, mais rígida deverá ser a disciplina externa, isto é a forma, a artificialidade, o ideograma, o sinal. Aqui está todo o princípio de expressividade.

Pavis (apud DE MARINIS, 1997, p. 78) destacará a centralidade da noção da partitura herdada de Grotowski em Barba, promovendo a extensão da experiência do primeiro na subpartitura sendo esta "aquilo sobre o qual o ator não deve parar de trabalhar."

Barba (2010b, p. 62) esclarece ao que diz respeito o termo partitura no Odin Teatret:

- ao desenho geral de uma sequência de ações (início, ápice, conclusão);

- à precisão dos detalhes de cada ação e de seus desdobramentos (sats, mudanças de direção, variações de velocidade);

- ao dinamismo e ao ritmo: a velocidade e a intensidade que regulavam o tempo (no sentido musical) de uma série de ações. Era a métrica das ações em suas micropausas e decisões, o alternar-se de ações velozes e lentas, acentuadas e não acentuadas, caracterizadas por uma energia vigorosa e macia;

- à orquestração das relações entre as várias partes do corpo (mãos, braços, pernas, pés, olhos, voz, rosto).

\footnotetext{
311 Pavis utilizar-se-á do exemplo de "esquema de trabalho para a abordagem da personagem" publicado em $I l$ lavoro dell'atore sul personaggio (1957), que tem seu equivalente em português na edição de A Criação de um Papel (STANISLAVSKI, 1998, p. 295-299).

312 Tomamos o trecho em português para a citação de Grotowski, equivalente ao trecho citado em Pavis, que está em italiano (apud DE MARINIS, 1997, p. 75).
} 
Como considerado no último item acima, a voz também faz parte da construção de uma partitura, sendo que as partituras físicas e vocais podem ser desenvolvidas separadamente e depois sobrepostas, misturadas, reorganizadas umas entre as outras.

A partir da criação de uma partitura, sua fixação depende da repetição dos mínimos detalhes alcançados, visando à precisão entre a ação e sua coerência interna, elemento que, para Barba (2010b, p. 64) é essencial para provocar a cinestesia no espectador. Barba enfatiza a característica da repetição como estratégia para se alcançar a organicidade:

Repetir, repetir, repetir. A ação no teatro é feita para ser repetida, não para alcançar um objetivo e ir além. Repetir significa resistir, opor resistência ao espírito do tempo, a suas promessas e ameaças. Só depois de ter sido repetida e fixada, uma partitura pode começar a viver. ${ }^{313^{3}}$

Mas a repetição é aliada e inimiga do trabalho do ator. Aliada ao possibilitar a lapidação das ações e incorporação das mesmas visando sua organicidade; a depuração das intenções e possibilidade de afloração da interioridade; a visão ampliada do entorno e da situação, gerando mais capacidade de relação com os outros atores, com o ambiente, com o espectador; enfim, a precisão do corpo em sintonia com todas as suas capacidades em ser/estar aqui e agora. Por outro lado, na repetição corre-se o risco do automatismo, da certeza e domínio que podem levar ao desinteresse e falta de engajamento com o que se está fazendo, ao clichê e perda das origens e motivações da ação.

As estratégias de cada ator para manterem vivas suas ações variam, assim como são variadas as personalidades, mas são processos achados no "trabalho sobre si mesmo" da dedicação ao fazer teatral. Carreri fala de sua motivação e sobre como realiza essa operação:

Porque, para mim, cada espetáculo, cada apresentação é a primeira e a última da
minha vida. Eu tenho uma sensação de que posso morrer esta noite, mas fiz o
máximo que eu podia. Então, cada vez que eu faço um espetáculo, claro, certo, eu
repito, eu sei as sequências das ações que eu preciso fazer, mas para mim, é a
primeira e última vez que eu vou fazer. E nesse sentido, para eu manter viva a ação,
tenho essa entrega total por um lado e por outro lado tenho essa técnica de
microimprovisação e quando falo micro é porque para mim tem a improvisação, mas
para o espectador é impossível ver porque é tão pequena a diferença visível, é tão
pequena, que quase não se percebe. Mas é importante para mim porque esse trabalho

${ }^{313}$ BARBA, 2003, discurso honoris causa em Varsóvia. Tradução nossa. Original: "Repetir, repetir, repetir. La acción en el teatro está hecha para ser repetida, no para alcanzar un objetivo y proseguir más allá. Repetir significa resistir, oponer resistencia al espíritu del tiempo, a sus promesas y amenazas. Sólo después de haber sido repetida y fijada, una partitura puede comenzar a vivir." Disponível em: <http://www.odinteatret.dk/media/41023/2003,\%20Warsawa\%20Univ\%20-\%20SP\%20Discurso.pdf >. Acesso em: 11/06/2014. Ver também BARBA, 2010b, p. 63. 
de microimprovisação me permite não repetir automaticamente, mas reinventar, a cada noite, a ação. ${ }^{314}$

Larsen também fala de improvisações:

Tento não pensar na próxima ação. Tudo o que digo, o que falo, é algo que eu invento, reinvento no momento. Eu tento ter cuidado de não responder algo que não tenha sido perguntado ainda. Eu espero que a pergunta seja feita para poder responder. No jogo [com outros atores], durante a troca de palavras e ações, não antecipar e manter a capacidade de improvisar. Eu não quero dizer cometer imprecisões, porque temos muitos pontos de encontro, e você sabe a deixa que os outros precisam, mas dentro disso, de cada frame fixado, de cada ação, você ainda tem espaço para muitas formas de improvisar. Você falar um pouco mais alto ou mais baixo ou mais rápido, às vezes. Isso me ajuda a manter vivo o que estou fazendo. Você precisa fazer as coisas como se estivesse fazendo pela primeira vez.

Varley (2010, p. 130) também recorre a pequenas mudanças de posturas, modos de dizer uma palavra ou frase, atentar à influência de outros personagens ou do público para prevenir o desgaste da repetição. Ela destaca algumas tarefas paralelas, como fazer o espetáculo em outra língua, que servem como estímulo para alimentar seu interesse em continuar fazendo os espetáculos.

E nessa repetição, como já apontado, o ator deve trabalhar igualmente sobre a justificação interior, a subpartitura. Barba (2010b, p. 65) a coloca como um "apoio interno, um pilar escondido" do ator, com correspondentes nas tradições por ele estudadas, como o subtexto, em Stanislavski, que se baseia na interpretação das intenções e pensamentos não expressos da personagem feita pelo ator; o diálogo constante proposto por Brecht travado pelo ator no questionamento sobre a verdade histórica a qual pertence sua personagem; as regras de cada tradição dos espetáculos codificados, como os teatros clássicos asiáticos ou o ballet clássico.

Pavis (apud DE MARINIS, 1997, p. 83-88) apresenta um compêndio de características da subpartitura a partir de respostas do grupo de artistas reunido na ISTA de $1992 .{ }^{315} \mathrm{O}$ autor baseia-se nas investigações ocorridas na ocasião sobre essa noção e a partir de particularidades recorrentes nas respostas, propõe a seguinte "definição coletiva":

Esquema diretor cinestésico e emocional, articulado com base nos pontos de referência e de apoio do ator, esquema esse criado e representado por ele, com a

\footnotetext{
${ }^{314}$ Entrevista concedida a mim durante estadia em São Paulo para a oficina A dança das intenções. 25/01/2013.

315 Apud DE MARINIS, 1997, p. 101-109.
} 
ajuda do encenador, mas que só pode se manifestar através do espírito e do corpo do espectador. $^{316}$

E, em outra formulação,

Quanto à "subpartitura", ela é essa sólida massa branca imersa sobre a qual se apoia o ator para parecer e permanecer em cena, tudo aquilo sobre o que ele baseia sua atuação. Trata-se do conjunto dos fatores situacionais (situação de enunciação) e das competências técnicas e artísticas sobre as quais o ator/atriz se apoia quando realiza sua partitura (PAVIS, 2010, p. 89).

E como registrar o que compõe essa massa entranhada? Varley $(2010$, p.130, 131), após reconhecer a dificuldade de colocar no papel as referências interiores que mantêm viva a partitura quando está em cena, conclui que subpartitura é um termo ainda útil e errado ao criticar a necessidade de separação entre dentro e fora, abaixo ou acima, notando que tudo se dá em fluxo e interação contínua. ${ }^{317}$

Refletimos que a subpartitura serve para tornar a partitura ao ator uma obra aberta, apesar de fixada, pela qual emergem potências nas relações entre si e os outros.

\subsubsection{Procedimentos compositivos ou modos de agir sobre os materiais}

Os atores do Odin Teatret possuem demonstrações de trabalho nas quais desconstroem seus procedimentos na conformação da dramaturgia, dando-nos um panorama de suas estratégias e lógicas pessoais. Tomaremos alguns como exemplos, com ênfase em demonstrações das atrizes Julia Varley e Roberta Carreri, assistidas durante as pesquisas de campo. $^{318}$

\footnotetext{
${ }^{316}$ Recorremos à tradução em português presente em PAVIS, 1996, p. 280.

317 Sottopartitura: ancora um termine utile e sbagliato. Risposte a Patrice Pavis é o título de um artigo produzido durante a $7^{\mathrm{a}}$ ISTA, em 1992 em Brecon e Cardiff. Apud DE MARINIS, 1997, p. 89-93; em português, cf. VARLEY, 2010, p. 121-131.

${ }^{318}$ Na minha última estadia em Holstebro, em junho de 2014, tive acesso a um texto de Anca Daniela Mihut, professora romena, em que ela descreve, através de suas anotações pessoais, algumas demonstrações de trabalho de Carreri, Varley e Rasmussen. Cf. The actor's dramaturgy notes, in STUDIA UBB DRAMATICA, LIX, 1, 2014, p. 71-95.
} 
Em $O$ tapete voador ${ }^{319}$, Varley exemplifica a aplicação de muitos dos exercícios descritos em sua Tradição (3.1.1) na elaboração de formas de ser dizer um texto. Com a frase "O texto é um tapete que deve voar bem longe" como mote, ela a divide em diferentes pontuações: "O/texto é um tapete que pode voar bem longe", "O texto/ é um tapete ...", O texto é/ um tapete...", por exemplo. Depois atribui qualidades às palavras por meio de imagens como a "neblina que abraça", "a fumaça que sobe", "a chuva que cai", ou de animais, como "uma leoa defendendo seus filhotes", entre outras. Também trabalha sotaques, em modos de falar como "Brejnev na praça vermelha", "Imperador da China" etc.; exemplifica com tipos como um professor, um comentarista esportivo, um sedutor. Ainda mostra como pode ilustrar sensações - excitada, calma, frio, quente, por exemplo- na forma de dizer uma palavra; atribui à fala as tensões das ações que os verbos têm, como carregar, apontar, empurrar, puxar, lançar, acariciar, correr. Canta o texto de várias formas, depois só com as vogais ou consoantes; traz referências de poesias e músicas que podem ser aplicadas à cadência do texto, modificando o modo de dizê-lo. Demonstra como sons dos pássaros serviram de inspiração para a característica da voz de Dédalo ${ }^{320}$, personagem de Mythos (1998).

Já em $O$ irmão morto ${ }^{321}$, Varley ressalta a colaboração entre atriz e diretor na criação de um espetáculo e lista suas estratégias: buscar ações não realistas, mas reais; achar a equivalência da força cotidiana; perceber os diferentes princípios que regem uma ação real: início/mudança/final; recorrer a deslocamentos de equilíbrio para transformar peso em energia; uso de oposições, diferentes direções; reconhecer os sats, momento de retenção do toda a energia antes de executar uma ação; aplicar uma lógica que não é casual nem linear, como p. ex. deslocar-se em sentido oposto ao dos braços, aplicar resistência aos pés para andar para frente; concentrar-se no que é necessário e não decorativo; para a ação ser crível, buscar a precisão das extremidades: pés, olhos, mãos; trabalhar com impulsos e contraimpulsos; mudanças interiores; delimitar o tema, texto, imagens e sequências usadas; aplicar tudo à partitura, que se modela pelo ritmo, qualidade de energia, redução das ações,

\footnotetext{
319 Há uma breve etnografia sobre este trabalho em Fenix, Revista de História e Estudos Culturais. Setembro/Outubro/Novembro/Dezembro de 2010. Vol. 7 Ano VII n.3 ISSN 1807-6971. FERNANDES, Adriana. Dalcroze, música e o teatro -fundamentos e práticas para o ator compositor. p. 17-22. Consulta em reprodução disponível no Odin Teatret Archives, pasta: Articles and interwies about Julia Varley I. Fonds Odin Teatret-Publications B1 6/6.

${ }^{320}$ Sobre essa personagem cf. VARLEY, 2010, p.176-190.

${ }^{321}$ A qual assisti pela primeira vez na Arte Secreta do Ator - Brasil, Brasília, 13/12/2010.
} 
aspecto introvertido e extrovertido, mantendo impulsos originais; transposições para uma parte do corpo, rosto, mãos, voz; uso dos objetos; fixação da partitura nos mínimos detalhes.

Em Traces in the snow, assistida durante a Odin Week, Roberta Carreri apresenta sua biografia de trabalho através das quatro estações ${ }^{322}$ em que o divide. Relata que o chão foi seu primeiro "mestre zen", por conta dos exercícios acrobáticos que aprendeu com os atores mais antigos do grupo, levando-a ter que estar presente e concentrada o tempo todo para não perder a conexão entre corpo-mente e poder realizá-los em diversas velocidades. Falando nos princípios como uma moldura de regras de trabalho dentro do qual se pode improvisar, apresenta os recursos da câmera lenta, formas diferentes de andar e de trabalhar com as mãos, uso de extroversão e introversão. Esses últimos serviram-lhe, por exemplo, para a aplicação na criação do comportamento de Gerônimo, uma personagem do espetáculo de rua Anabasis (1974).

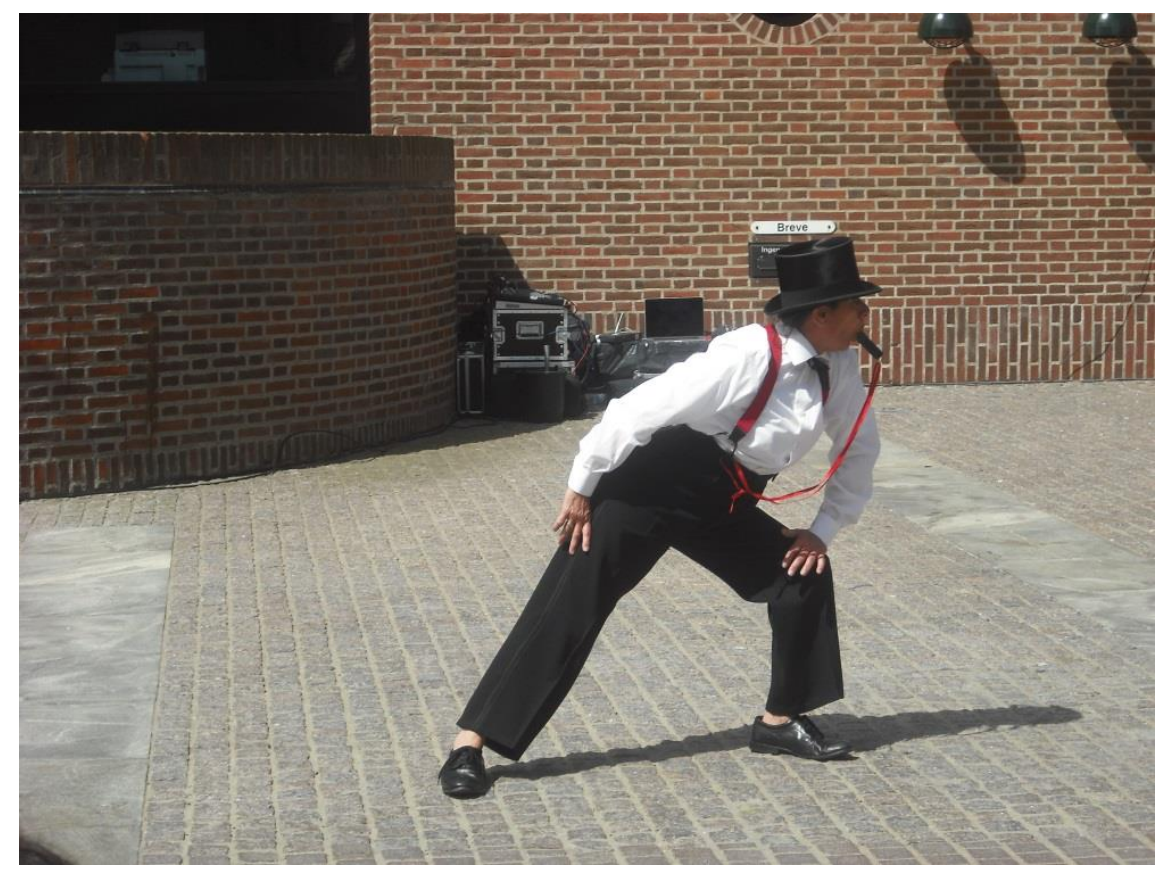

Figura 32. Gerônimo. Festuge, 2014, Holstebro, Dinamarca. Foto: Leticia Olivares.

Carreri ainda tem outras demonstrações como, Nora's way em que trabalhou a partir de um texto dramático, a Casa de Bonecas, de Ibsen, para chegar à partitura. Originalmente, ela e Wethal sentiram-se desafiados por uma questão de participantes de um workshop, sobre

${ }^{322}$ Ver p. 139 deste trabalho. 
como, em estruturas mais convencionais, poderiam aplicar a técnica. ${ }^{323} \mathrm{Na}$ demonstração a que assisti, já somente com Carreri, contou-nos que não tem experiência com o teatro feito a partir de um texto pronto, por ter sempre trabalhado no Odin Teatret. Então, a partir da cena final texto de Ibsen, quando a personagem vai embora, baseou-se em imagens e estímulos que o texto lhe trazia para montar o modo de agir de Nora. A cena começa quando a personagem entra na sua casa, recurso que Carreri adaptou, pois no texto original, nesse momento da peça, ela já está em cena. A atriz relata então, as imagens que lhe surgem, ao ver seu marido e sentir que estava sendo "sugada". O chão passa a ser lamacento e estas imagem e sensação fazem com que tenha dificuldades para andar, atribuindo qualidades físicas diferentes ao seu deslocamento. Korish (2002, p. 286) destaca que a atriz trabalha literal e associativamente ao mesmo tempo, ou seja, ela usa a informação do chão com lama, que traduz seu entendimento sobre o momento da personagem, literalmente e a associa a uma condição interna que se reflete em sua expressão física. Carreri chama a atenção para a "redução" das ações criadas, para serem condizentes com a personagem e o texto. Demonstra como, por exemplo, a ação de tirar o anel de casamento com a boca, inicialmente grande e dramática, torna-se menor, porém sem perder a sua origem. Nesse sentido, também trabalhou o espaço das ações em "plano americano", isto é, da cintura para cima, deixando tudo muito pequeno. Ainda, objetos como uma mala, chaves servem para a atriz procurar informações que a ação de manipulá-los pode conter, segundo a lógica da personagem.

As montagens também podem levar muito tempo para ser feitas. Isso se dá porque muitas vezes os processos pessoais correm em paralelo com a agenda do grupo, seja em novas montagens ou viagens para apresentações, e/ou cursos que ministram no mundo todo. Carreri e Ferslev $^{324}$ trabalharam durante cinco anos, por exemplo, no que viria a ser a peça Salt $^{325}$. O tema "nostalgia" foi inspiração para experimentar elementos, instrumentos, testar músicas, textos e partituras. A palavra "jornada" também servia como tema e isso a fez colecionar malas durante o período da montagem. O diálogo com as músicas que Ferslev criava, serviam como impulso, por exemplo, para falar um texto dramaticamente, em pé sobre um xale preto. Imagens de Picasso serviram-lhe para compor uma sequência de ações, assim como esculturas de Rodin transformaram-se em transições para o texto que foi trabalhado com o diretor de

\footnotetext{
${ }^{323}$ Cf. KORISH, David, The Mud and The Wind: an Inquiry into Dramaturgy, 2002, p. 284.

${ }^{324}$ Demonstração de trabalho Letter to the Wind (Carta ao vento) assistida por mim durante a Odin Week, 25/08/2013.

${ }^{325}$ Cf. também CARRERI, 2011, p. 171-180.
} 
várias formas: dito muito rápido, seguindo a música tocada por Ferslev, e por fim, sentada, sem fazer nada, mantendo os impulsos internos das construções anteriores. Durante o processo, Carreri destaca o papel do diretor que "destrói as obviedades e as coisas belas por si só”, trazendo outro ponto de vista. Diz que os cortes e mudanças doem muito para o ator, só que, de Barba, sempre ouve: "Kill your darlings", em livre tradução, "Mate seus queridinhos". O processo todo levou oito anos para ser concluído. Mas Carreri salienta que o tempo que a peça não está sendo trabalhada na sala de ensaio, ela continua em processo interior de criação. ${ }^{326}$

A fase de elaboração do material é salientada por Varley (2010, p. 111) como a mais importante do processo criativo do ator no Odin Teatret. E prenuncia o confronto posterior com a montagem do diretor e o sentido que o trabalho individual sobre os materiais vai adquirir na relação com os outros atores, com o texto do espetáculo e os outros elementos que o compõe na dramaturgia final orquestrada por Barba.

\footnotetext{
${ }^{326}$ Todo esse parágrafo está baseado em anotações pessoais diante da demonstração de trabalho apresentada na Odin Week, Holstebro Dinamarca,
} 


\section{CAPÍTULO IV}

\section{SANGUE E CÉREBRO}

"[...] o artesanato teatral se insere no que se tem no sangue e não somente naquilo que se pensa com o cérebro." (BARBA, 2006, 29)

Ao ter que discorrer sobre o processo de apropriação do treinamento e de criação, o olhar voltou-se para dentro, mas também para os rastros e para as relações. Em uma arqueologia pessoal, os conteúdos acumulados em vários anos no ofício e na sua pesquisa foram aparecendo e transbordando. Diários de trabalho, que datam de bem antes do mestrado começaram a vir à tona, como ossos mal enterrados ou pequenos tesouros achados no fundo do mar. Vejo que a busca sempre foi a mesma, caminhos ocultos para achar a relevância de meu ser artista. A minha pergunta esfinge.

A sistematização de processos responde à tendência dos estudos que unem teoria e prática. Como pode o ator falar de seu trabalho sem basear-se somente em sensações e ideias vagas sobre a criação? Ao mesmo tempo, como não abrir mão da poética, contaminando sua escrita também com o corpo-vida que queremos no palco? Ao mapear um processo, colocamse em diálogo as vivências e teorias com o trabalho da atriz-pesquisadora, as ressonâncias que dele surgem, as influências que sofremos e as referências a que recorremos.

Na perseguição da convergência entre o estudo e a práxis, "estar presente" permeou também a experiência da escrita. A cada pulso do meu coração, conforme realizava a tradução em palavras dos conceitos e práticas que me propus a aprofundar, sentia o sangue correndo em minhas veias, por vezes muito lentamente, em outras como borbotões de uma enxurrada. O estado de atenção se ampliava principalmente ao descrever os exercícios, que muitas vezes tinham que ser refeitos, mesmo reduzidos, enquanto na cadeira de escritório tentava seguir um fluxo entre referências escritas, lembranças e impulsos corporais. E assim se deu também com o processo de criação da cena, no diálogo entre a escrita e o fazer. A facilidade, porém que a construção "pesquisa teórico-prática" na grafia assume, ao lidarmos com processos, mostrouse muito mais complexa. O encanto da escrita e a sedução das fontes, com seu vasto material, também levaram a momentos de pura formulação para compor o corpo da dissertação em um trabalho mental que se exaure na dor física das costas e na flacidez da expressão. Mas a 
formulação intelectual é uma pequena contribuição do que serve ao ator, lembra-nos Grotowski (2011, p. 157) "Uma filosofia sempre vem depois da técnica! Você anda na rua com suas pernas ou com suas idéias?"

A disciplina exigida pelo treinamento solitário, que cumpri por muitos anos anteriores, nesta fase foi uma luta e promoveu questionamentos sobre a pertinência dos exercícios, não em sua eficiência em si, mas em minha eficácia em realizá-los. A forma de contornar tal dificuldade se revelou na busca de uma ressignificação para o que estava fazendo, ao invés de mera cópia do que tinha vivido junto aos mestres. Nesse sentido, a capacidade de precisão, a atenção ao que o exercício me produz como estado e as possibilidades de confronto com o conhecido e dominado serviram de vontade de continuar. Já quando estava em grupo, como em cursos com os atores do Odin Teatret, junto ao Coletivo Rubro Obsceno ou, ainda, ministrando aulas, a disposição era mais facilmente acionada e os exercícios repassados com vigor e prazer.

Porém, a dificuldade em realizar o treinamento sozinha levou-me a tentativas de solução para o meu corpo e momento. ${ }^{327}$ Alongamentos na cadeira de escritório, técnicas de respiração, partituras reduzidas que cabiam no meu quarto e que muitas vezes eram executadas ou criadas no meio da escrita. Na cena, achar o fio para todo o material levantado também foi um problema, creio que acentuado por essa característica errática entre texto teórico, prática técnica e criativa. Mas como magma escondido no fundo da terra, a criação borbulhava com insigths sobre a montagem, com muitos textos e partituras aparentemente desconexos, mas que estavam no "caldo" fervendo juntos nesse laboratório alquímico que abriga o trabalho do ator. A resposta para a estrutura da cena acendeu-se já no tempo final ${ }^{328}$ da pesquisa, quando juntei as duas performances em que estava trabalhando, Em si mesmas ${ }^{329}$

\footnotetext{
${ }^{327}$ Falando por $e$-mail a Julia Varley sobre as minhas dificuldades físicas e a angustia da criação da cena, sua resposta, transcrita na íntegra, foi: "Sobre o mestrado. É normal que depois de tantos anos trabalhando se perde o sentido. Tem que continuar mantendo também una distancia com você mesma. O primeiro é aprender a falar em primeira pessoa, buscar as motivações e as palavras pessoais, depois tem que dialogar com você mesma como advogado do diabo, com a distancia de quem já passou por tudo e sabe que o importante jamais será dito. $\mathrm{O}$ treinamento muda com os anos, com os novos interesses. Se pode treinar ficando sentados numa cadeira! Acho que você tem que terminar o trabalho [cênico]. Tinha momentos muito bons e tinha perguntas que precisam ser perseguidas, não abandonadas! Então: a trabalhar!" (correspondência eletrônica, 21/08/2014).

${ }^{328}$ E o curso da Professora Claudia Jenchke já citado foi fundamental para embasar algumas vontades de trabalhar todos os elementos que tinha em mãos e que já se desenhavam nesse caminho. Não chamo, no entanto de lecture performance o que apresentarei, mas me aproprio de uma noção de sua estrutura, segundo o curso que frequentei acima mencionado: a possibilidade de caminhar entre teoria e prática cenicamente. Pensando em uma definição para a estrutura da cena, optei nominá-la como uma demonstração de processo.
}

${ }^{329}$ Sobre esse processo ver APÊNDICE, p.218. 
e Em um corpo $s o^{330}$. A semelhança dos temas, apesar de serem processos independentes, também me chamou à atenção: níveis de solidão. Essa, ao que parece, um problema crônico da contemporaneidade.

Nesse caminho, "o fazer transformando o pensar e o pensar transformando o fazer geram uma espiral incessante.” (BONFITTO, 2006, p. 142) em uma aventura pessoal que necessita ser revitalizada dia a dia.

\subsection{Raiz e pólen}

\begin{abstract}
O teatro é constituído de raízes que brotam e crescem num lugar bem preciso, mas também é feito de sementes trazidas pelo vento, seguindo as rotas dos pássaros. Os sonhos, as ideias e as técnicas viajam com os indivíduos, e cada encontro deposita o pólen que fecunda. Os frutos amadurecem devido ao trabalho teimoso, à necessidade cega e ao espírito de improvisação, e contêm as sementes de novas verdades rebeldes.
\end{abstract}

Eugenio Barba

Desenvolver seu próprio treinamento é segundo Barba, ${ }^{331}$ criar raízes e poder frutificar como ator. Para alimentá-lo, além da disciplina, há a curiosidade sobre onde se pode chegar com cada experimentação, o aprofundamento sobre detalhes e a percepção de que nada é em geral. Antes, a particularidade de cada corpo e cada fazer é o que pode humanizar a técnica tornando-a viva e provedora de matéria e sentido ao fazer teatral.

\subsubsection{Meu "tai chi" pessoal}

Pensando na busca da minha autonomia na tradução dos procedimentos dos atores do Odin Teatret e as bases teóricas estudadas, como já dito, tive que levar em consideração

\footnotetext{
${ }^{330}$ Trabalho, sob esse nome, cenas elaboradas a partir das referências dos diários desde 2008. A primeira versão da cena foi apresentada no Seminário de Dança-teatro em Viçosa, em 2010 (cf. comunicação sobre apresentação: <https://www2.dti.ufv.br/danca_teatro/evento/apresentacao/artigos/gt1/leticia.pdf> Acesso em: 27/08/2014); a segunda, na mostra de trabalhos do Encontro e Festival Vértice, em Florianópolis, no mesmo ano.

${ }^{331}$ Anotação pessoal, A Arte Secreta do Ator - Brasil, Brasília, 2009.
} 
vários limites físicos e me confrontar diariamente com a disciplina necessária para provar o que procurava, o estudo dos princípios que levam à presença cênica e a montagem dos materiais colhidos na fase "pré-expressiva".

O treinamento serviu para experimentar e explorar, no corpo, dinâmicas e qualidades de voz e movimento em relação a mim mesma, aos outros e ao espaço. ${ }^{332}$

Minha atenção esteve também nos meus pés e nas transferências de peso. E na respiração e emissão de voz, outras dificuldades. Os mecanismos para cessar o pensamento automático passam pelo treinamento e por uma constante vontade de superação ao mesmo tempo em que se é necessário seguir e se contentar com a materialidade do momento/coisa com que se está lidando. Dentro da estrutura de exercícios experimentados procurei pelos pressupostos, anotando o que identificava como resultado da prática. E assim, mapear também as qualidades, as sensações, os diferentes estados que me permeavam a cada repetição.

Montei um quadro com algumas experiências, a fim de exemplificar componentes tomados para a criação do meu treinamento pessoal e a utilização das fontes.

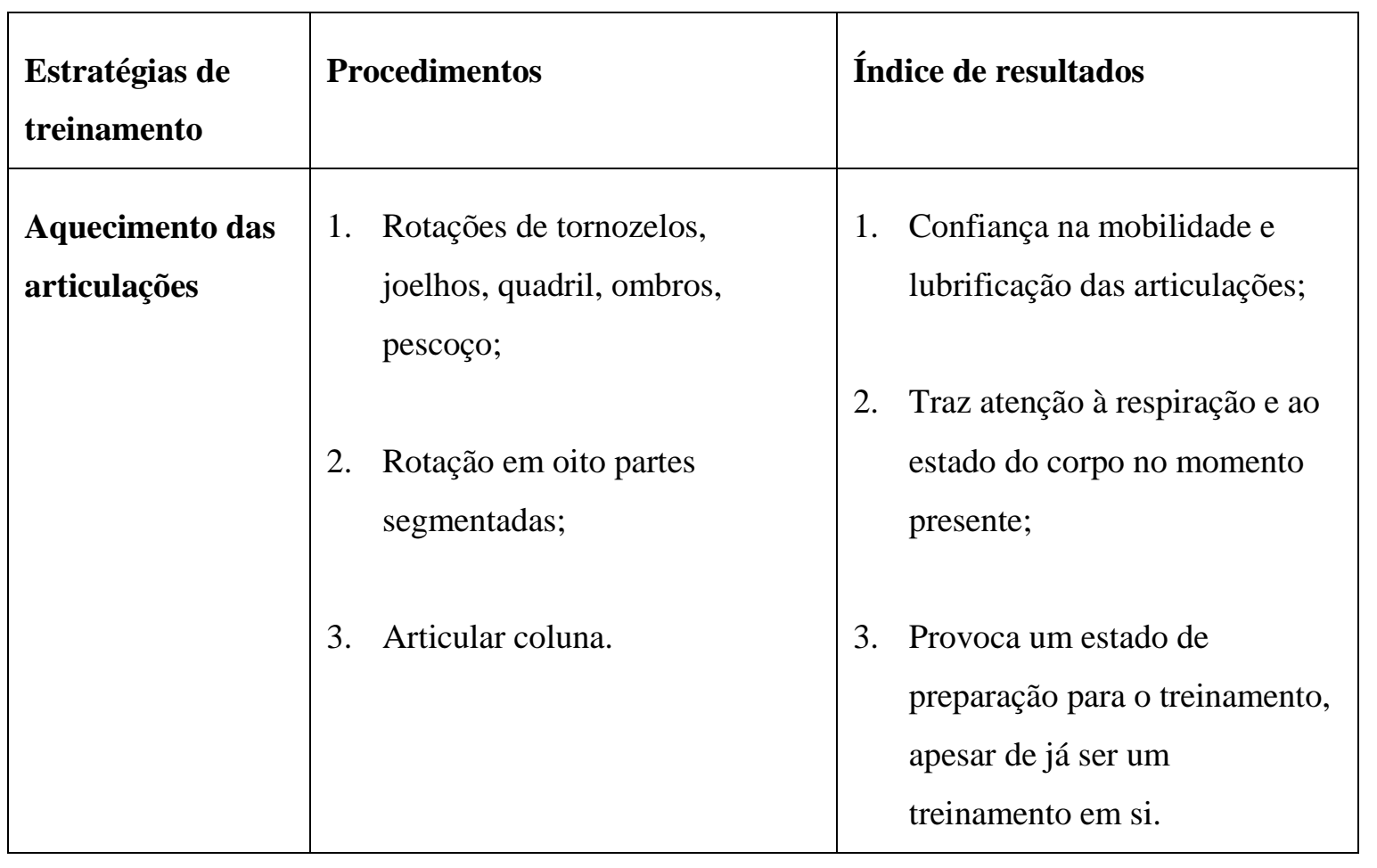

\footnotetext{
${ }^{332}$ Considero relevantes os dois anos fiz aulas regulares de Pilates, incorporando a técnica em meu aquecimento pessoal. Esse cuidado se mostrou imprescindível na preservação da coluna vertebral e fortalecimento muscular. Desde o início do mestrado, frequentei aulas de dança com a Prof. ${ }^{a}$ Dr. ${ }^{a}$ Sayonara Pereira no grupo de pesquisa Lapett - Laboratório de Pesquisa e Estudos em Tanz Theatralidades (ECA-USP), que também foram importantes para o condicionamento corporal.
} 


\begin{tabular}{|c|c|c|}
\hline $\begin{array}{l}\text { Exercícios } \\
\text { de yoga } \\
\text { (tradição Hatha) }\end{array}$ & 1. Saudação ao sol. & $\begin{array}{l}\text { 1. Efetivamente começa a } \\
\text { produzir um estado alterado de } \\
\text { temperatura, trabalho de força } \\
\text { e flexibilidade, atenção à pausa } \\
\text { e fluxo de movimento, atenção } \\
\text { à respiração. }\end{array}$ \\
\hline $\begin{array}{l}\text { Exercícios de } \\
\text { Pilates }\end{array}$ & $\begin{array}{l}\text { 1. No chão, basculamento do } \\
\text { quadril com elevação; } \\
\text { 2. Abdominais lentos; } \\
\text { 3. Elevação dos braços: lateral e } \\
\text { sagitalmente; } \\
\text { 4. Em pé, "enrolar e desenrolar" } \\
\text { coluna. }\end{array}$ & $\begin{array}{l}\text { 1. Aquecimento e lubrificação da } \\
\text { área lombar, facilitando sua } \\
\text { articulação; } \\
\text { 2. Força abdominal, fechamento } \\
\text { das costelas, respiração; } \\
\text { 3. Acionamento de escápulas e } \\
\text { musculatura lateral e posterior } \\
\text { do tronco; } \\
\text { Articulação consciente da } \\
\text { coluna vertebral, acionamento } \\
\text { de musculatura posterior das } \\
\text { pernas para gerar equilíbrio, } \\
\text { relaxamento do quadríceps. }\end{array}$ \\
\hline $\begin{array}{l}\text { Exercícios de Tai } \\
\text { Chi Chuan }\end{array}$ & $\begin{array}{l}\text { 1. Tendões; } \\
\text { 2. Árvore; } \\
\text { 3. Sequências interligadas (neste } \\
\text { caso "inventei" a minha } \\
\text { sequência). }\end{array}$ & $\begin{array}{l}\text { 1. Flexibilidade, atenção à } \\
\text { respiração; } \\
\text { 2. Trabalho da "energia } \\
\text { invisível"; } \\
\text { 3. Aterramento, fluidez, }\end{array}$ \\
\hline
\end{tabular}




\begin{tabular}{|c|c|c|}
\hline & & contenção da força. \\
\hline $\begin{array}{l}\text { Dança moderna } \\
\text { Aulas com a Profa. } \\
\text { Dra Sayonara } \\
\text { Pereira }\end{array}$ & $\begin{array}{l}\text { 1. Sequência de encerramento das } \\
\text { aulas incorporada como } \\
\text { partitura, aplicando qualidades, } \\
\text { texto e intenções ao } \\
\text { movimento. }\end{array}$ & $\begin{array}{l}\text { 1. Maior engajamento do tronco } \\
\text { nos movimentos, consciência } \\
\text { da coluna vertebral, fluidez, } \\
\text { entrecruzamento e } \\
\text { ressignificação de materiais. }\end{array}$ \\
\hline $\begin{array}{l}\text { Exaustão } \\
\text { Aqui também } \\
\text { entraram alguns } \\
\text { exercícios da } \\
\text { tradição de Tage } \\
\text { Larsen e Roberta } \\
\text { Carreri }\end{array}$ & $\begin{array}{l}\text { 1. Duração mínima de } 30 \text { minutos } \\
\text { à máxima testada por duas } \\
\text { horas; } \\
\text { 2. Corrida, saltos, mudança de } \\
\text { planos: andar de quatro, } \\
\text { cambalhotas, arrastar-se, } \\
\text { floating. }\end{array}$ & $\begin{array}{l}\text { 1. Mudança de temperatura do } \\
\text { corpo e do espaço; } \\
\text { 2. Encadeamento das qualidades } \\
\text { "surpresa" e "decisão", uso do } \\
\text { espaço, percepção de } \\
\text { pensamentos intrusos, } \\
\text { percepção de superação do } \\
\text { cansaço e início de um estado } \\
\text { alterado de conexão corpo- } \\
\text { mente. }\end{array}$ \\
\hline $\begin{array}{l}\text { Outros exercícios } \\
\text { herdados dos } \\
\text { atores do Odin } \\
\text { Teatret }\end{array}$ & $\begin{array}{l}\text { 1. Tradição Julia Varley: Contar } \\
\text { ações; } \\
\text { 2. Tradição Roberta Carreri: } \\
\text { Câmera lenta, formas de sentar, } \\
\text { verbos; } \\
\text { 3. Tradição Tage Larsen: Estátuas } \\
\text { (Marble); }\end{array}$ & $\begin{array}{l}\text { 1. Varley: apropriação do início e } \\
\text { fim de cada ação, consciência } \\
\text { das transições, capacidade de } \\
\text { repetição; } \\
\text { 2. Carreri: desafios ao equilíbrio, } \\
\text { utilização de direções } \\
\text { espaciais, trabalho com ritmos } \\
\text { e intenções; } \\
\text { 3. Larsen: Imobilidade ativa, }\end{array}$ \\
\hline
\end{tabular}




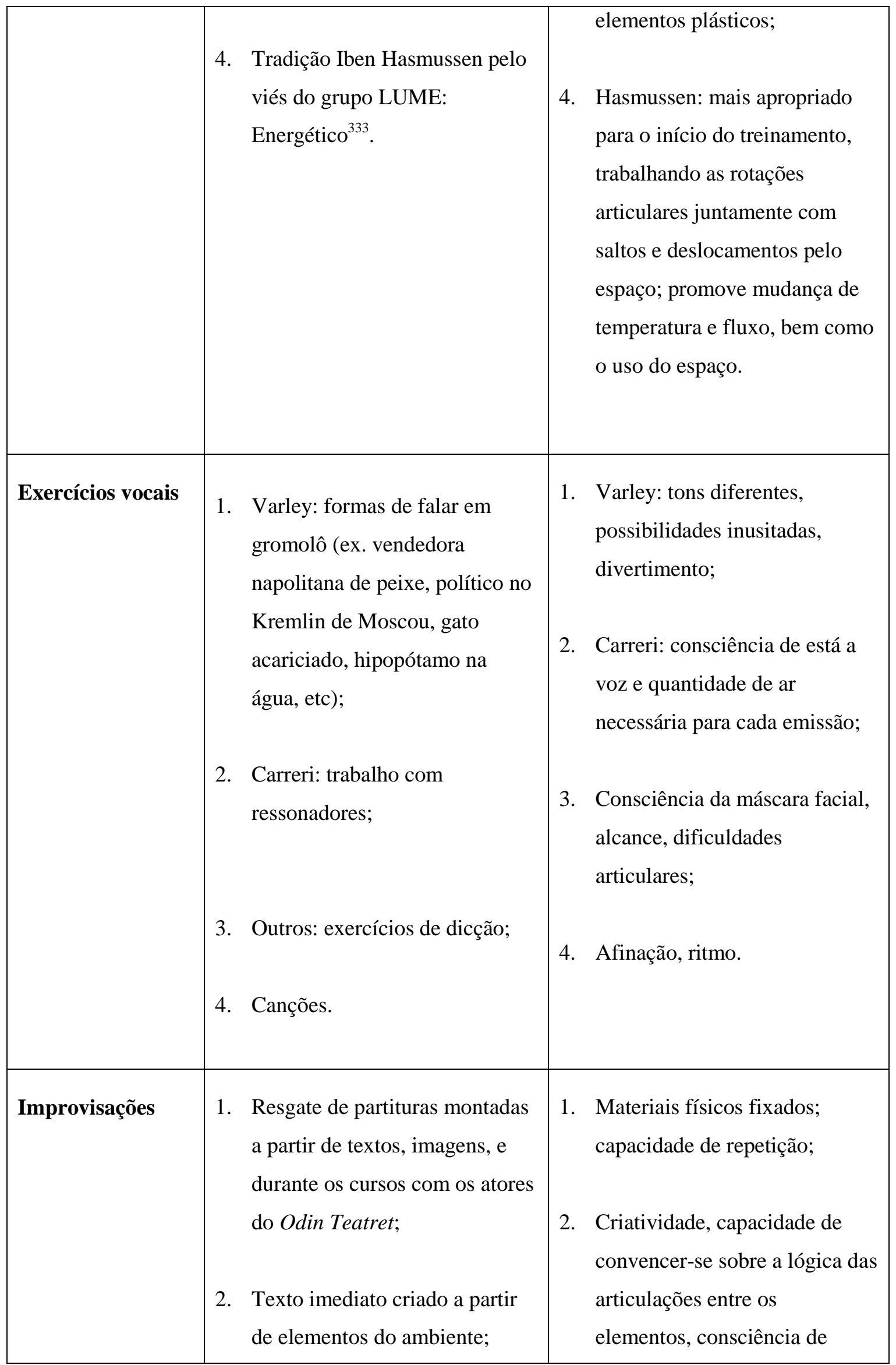

${ }^{333}$ Cf. FERRACINI, 2003, p. 137-143. 


\begin{tabular}{|l|l|l|}
\hline 3. $\begin{array}{l}\text { Com música: alinhar } \\
\text { movimentos da partitura com } \\
\text { ritmos da música, idem contra } \\
\text { ritmos da música; }\end{array}$ & $\begin{array}{l}\text { autocrítica bloqueadora, } \\
\text { capacidade de repetir o que foi } \\
\text { criado; }\end{array}$ \\
& $\begin{array}{l}\text { 3. } \begin{array}{l}\text { Descobrir variações de tônus, } \\
\text { qualidades de movimento } \\
\text { (leve/pesado, rápido/lento, } \\
\text { mesma partitura. }\end{array} \\
\text { pequeno/grande); }\end{array}$ \\
& $\begin{array}{l}\text { Achar justificativas entre texto } \\
\text { e ações. }\end{array}$ \\
\hline
\end{tabular}

Ter testado todas essas estratégias e ainda outras serviu para a seleção dos procedimentos de treinamento e eleição organizada dos "pontos de partida". A partir dessa experiência, configurei o meu treinamento pessoal buscando o fluxo, a relação com o espaço, com o dentro-fora, com os princípios, em uma espécie de tai chi pessoal. Chamá-lo de "tai chi” teve inspiração na experiência da prática nas manhãs de A Arte Secreta do Ator - Brasil (2009 a 2011), na qual Barba certa vez relacionou o cumprimento da arte marcial, punho esquerdo fechado e mão direita por cima, com o "coração da ação" que fica escondido na partitura. ${ }^{334} \mathrm{E}$, na pesquisa sobre essa prática, algumas orientações me interessaram para confrontar tendências, estruturar personalizações e trabalhar os princípios pré-expressivos,

No aprendizado do Tai Chi Chuan deve-se primeiro começar com a Forma [partitura], aprendendo de acordo com as rotinas [treinamento] e seguir os movimentos do professor [a inspiração dos mestres] de forma muito consciente e cuidadosa [também com articulações] e manter cada ação em sua mente [estar aquiagora]. Ao mesmo tempo deve prestar atenção ao NEI = interno; WAI = externo; SHANG = acima e XIA = abaixo. NEI = INTERNO significa usar a mente $[0$ corpomente], ao invés da força [e da vontade de expressar]. WAI = EXTERNO significa o relaxamento dos membros, ombros e cotovelos, realizando os movimentos desde os pés para as pernas, para a cintura, de forma suave e contínua [transferências de peso transformadas em energia, transições]. SHANG = ACIMA significa manter a cabeça sempre erguida, alta [conexões ósseas, presença]. XIA = ABAIXO significa submergir a respiração no baixo ventre [enraizamento]. ${ }^{335}$

\footnotetext{
${ }^{334}$ Anotação pessoal. A Arte Secreta do Ator - Brasil, Brasília, 09/12/2011.

${ }^{335}$ Disponível em: <http://www.sbtcc.org.br/>. Consulta em: 03/08/2014.
} 
Então, para organizar esta estrutura como treinamento, isolei alguns pressupostos:

- Que sirva para aquecer articulações, inclusive de forma preventiva, evitando lesões;

- Trabalhar o lento e suave, conscientemente, em contrapartida às tendências ao forte e pesado;

- Ative a atenção dentro-fora. Para isso, ajuda-me ter consciência dos vetores corporais, do uso da musculatura e rotação dos ossos, da respiração, dos impulsos que percorrem minha coluna e do desenho tridimensional que meu corpo assume no espaço e as imagens que são criadas, tanto na subpartitura quanto na forma externa;

- Contenha os princípios de oposição/negação/contramovimento, redução/omissão, equivalência, equilíbrio de luxo. Nesse caso, torções/mudanças de direção/leves impulsos contrários, pausas dinâmicas (que trabalham o pequeno em contrapartida à tendência ao grande), transposições, desequilíbrios são utilizados;

- Seja fluida e interligada. E dessa forma, achar transições que "sirvam de trampolim"336 para a próxima ação, trabalhando a tendência de dar saltos de uma ação para outra, desconectando-as.

- Tenha o trabalho de voz incorporado. As experiências se deram tanto com exercícios de aquecimento vocal, como com textos e ainda com sons espontâneos.

- Considere as imagens interiores, as "peripécias" (BARBA, 2012, p.54), ou seja, os saltos de pensamento, associações particulares que nos levam a reagir. É claro que os saltos de pensamento existem o tempo todo, criando imagens, sensações e emoções, mas, para poder observar esse ponto do treinamento e pesquisar a capacidade de "surpreender-me", experimentei adotar um "espaço vazio" na sequência do treinamento. Inicialmente fixei esse momento, ou seja, depois de determinada ação, poderia improvisar livremente, para retomar a estrutura na sucessão criada, mas depois de incorporada a repetição, permitia que as improvisações acontecessem em qualquer ponto dela. A atenção voltou-se, então para reações a partir de impulsos e escuta, como o barulho externo, a respiração, uma música, uma luz que pisca no teto, lembranças. A partir do material da improvisação, nasceram mais detalhes que incorporados ao treinamento, e assim, as descobertas podem continuar.

- Tenha deslocamentos;

${ }^{336}$ Anotação pessoal de fala de Varley durante A Arte secreta do ator-Brasil, Brasília, 2010. 
- Que seja passível de repetição;

\subsubsection{A transmissão da técnica}

Devo ressaltar a importância da aplicação dos procedimentos que considero potentes para o ator/bailarino em processos de formação e criação ${ }^{337}$ para os "resultados" da minha pesquisa. Considerando essas experiências como o "pólen" que posso aspergir a partir dos meus entendimentos sobre a técnica, elas foram particularmente ricas em se tratando de:

1. Perceber como eu estava transmitindo a "herança", o que já é meu, o que aplico com propriedade e o que ainda é apenas um procedimento exterior a mim.

2. Como os procedimentos faziam "sentido" ou não para as outras pessoas; e como explicar o "sentido" do procedimento, se fosse necessário.

3. Como adaptar o que eu via não funcionar como estímulo em novas configurações, gerando outras analogias ou entrecruzando informações.

4. O que já é uma "invenção" minha a partir da apropriação ou mesmo de outras referências/treinamentos que já cursei.

Como consequência desse entendimento, tracei algumas considerações, principalmente a respeito da transmissão da técnica e à auto-observação na sua passagem. $\mathrm{O}$ "sentido" esteve diretamente relacionado às reações do meu corpo sobre o que eu estava falando; a aplicação pedagógica dos procedimentos fazia "sentido" em respostas ou reações corporais sobre o entendimento do princípio ativo. Por exemplo, ao aplicar exercícios ligados ao princípio da oposição, meu corpo (ou seja, eu) imediatamente era acionado na realização interna, muscular, fisiologicamente engajado com o que entendo sobre o mesmo. A explicação não vem nunca separada do acontecimento do princípio em mim. Isso ressoa como conhecimento, um domínio intrínseco sobre o que estou falando e me dá certa segurança em transmitir.

\footnotetext{
${ }^{337}$ As aplicações consideradas nesta pesquisa levam em conta os seguintes processos: treinamento, montagem da dramaturgia final e direção do espetáculo Catadióptico (2011/2012); treinamento junto ao Coletivo Rubro Obsceno e montagem na performance Em si mesmas (2013/2014); curso ministrado, voltado para a criação cênica, na Cia Fragmentos (dança contemporânea -2014); assistência de direção no grupo de pesquisa Lapett (2012 a 2014), e aulas ministradas nas disciplinas de Poéticas do corpo e da voz I e Atuação I para graduandos na ECA-USP (2012/2013/2014).
} 
O reconhecimento da "verdade", como diz Barba (2010b, p. 88) "aquilo que se acredita e afirma", se deu mais potentemente no momento presente das aulas, quando sentia todas minhas células comprometidas com o que estava proferindo, buscando, muitas vezes nas sensações e reações, as respostas aos procedimentos que tratava de aplicar. Esse aprendizado, fornecido pela transmissão da pesquisa, foi o maior treinamento a que me submeti. Principalmente junto a grupos mais inexperientes, como é o caso de jovens atores ingressantes no curso de Artes Cênicas da USP, as conexões com técnicas corporais e conhecimento sobre anatomia foram importantes, pontuando estratégias de relaxamento, direção e vetores corporais, instruções mecânicas como "fechar costelas", maneiras de fortalecer músculos ou acionar pontos específicos para conseguir maior equilíbrio, por exemplo.

Particularmente, na aplicação dos princípios junto a atores no contexto da formação, preocupa-me a estrutura disciplinar, que não favorece uma pesquisa continuada e interligada entre as disciplinas, causando-me a sensação de que as informações e vivências de uma aula ficam isoladas e circunscritas em si mesmas. Para isso, alimento um ideal de que, cada vez mais, o pensamento pedagógico possa se nortear para a interdisciplinaridade e nutra o estado criativo do estudante-artista, propiciando um ambiente onde as aplicações façam "sentido carnal" no diálogo entre as disciplinas.

Já na experiência com atrizes mais experientes, como as do Coletivo Rubro Obsceno, as questões do treinamento voltaram-se para a conexão com a criação: de que serve fazer tais “exercícios"? Uma das percepções colhidas, que saliento, é a de que a prática física - como frisava Grotowski - desbloqueia os automatismos e nos leva a outros estados de percepção, deixando-nos mais permeáveis para o "mundo interior" que pode aflorar sem mediações entre a intenção e a execução do ato. Essa constatação é possível apenas através de sua duração, ou seja, fazer e fazer, experimentar e insistir no que muitas vezes pode parecer aborrecido ou sem sentido, em uma descoberta constante de motivações internas que nos levam a continuar.

\subsection{ENTRE O ÍNFIMO E O INEXORÁVEL}

A construção de uma apresentação cênica finalizada aspirada como resultado transformou-se diante da aplicação de treinamentos e da escrita. Na sua organização, o lugar da pesquisa misturou-se nesse cenário em uma conversa entre o fazer, sua escritura e inter- 
relações. O interesse voltou-se então para as permeações entre a escrita e a criação, entre o mental e o físico.

Fortin (2009, p. 81) chama a atenção sobre "a dupla exigência da pesquisa criativa":

Pierre Gosselin (ver Gosselin e Laurier, 2004) nos lembra que o estudante em prática artística enfrenta um duplo desafio: de um lado, aquele da produção de uma obra artística que chama interpretação polissêmica e, de outro lado, aquele de uma produção textual oferecida às interpretações mais convergentes. $\mathrm{O}$ artista que tem $\mathrm{O}$ hábito de selecionar e de manipular os materiais para produzir a obra artística está convidado a reconhecer nos dados etnográficos dos materiais que o apoiarão na fabricação de sua produção discursiva. Os dados etnográficos são de alguma maneira os materiais sobre os quais se encontra a escrita da tese.

A estrutura que já vinha sendo trabalhada contaminou-se com a própria dificuldade entre o trânsito do que é o trabalho intelectual e o que é a vivência de todos os conceitos. Permiti que as angústias e interferências virassem também cena, como pretexto de trafegar entre as questões que me mobilizavam. Perseguir algumas noções desta pesquisa alimentou, então, o decurso criativo estruturando a escolha da chamada demonstração de trabalho em processo, em que evidencio os estímulos em um jogo entre estar escrevendo a dissertação, pensando-a e criando a cena. As noções que destaco são: desvelamento, "trabalho sobre si mesmo", Desordem ${ }^{338}$, o descobrimento e o descoberto, passagem do corpo cotidiano para o corpo extra-cotidiano, visível e invisível, projeção da presença, simultaneidade, surpreenderse e surpreender o espectador, cinestesia, materialidade e sentido, dramaturgia orgânica. Ainda, pesquisar as passagens de estados entre a emanação da presença cênica e sua ocultação. Construir e abandonar os estados para em seguida retomá-los. Brincar com a estrutura de ser e não ser, ocultando as intenções nas subpartituras e explorando os impulsos no corpo com sutileza, para mapear as micropercepções ${ }^{339}$ que me acometiam, no que chamo de iscas osteomusculares.

\footnotetext{
338 “A experiência da desordem não diz respeito às categorias da estética. É quando uma realidade prevalece sobre a outra. Como acontece no universo da geometria plana, quando de repente, cai um sólido. Como acontece, sem que a gente espere, quando a morte fulmina uma pessoa querida. Como quando, em menos de um segundo, os sentidos incendeiam e sabemos que estamos apaixonados.” BARBA, 2010b, p. 51.

${ }^{339}$ Sobre micropercepções ver FERRACINI. Atuações, fronteiras e micropercepções. In: Sala Preta, 2010 , v. 10. p. 229-241. Disponível em: <http://www.revistas.usp.br/salapreta/article/view/57452>. Acesso em: 22/08/2014.
} 
Reconhecendo que a criação se dá em um contínuo, permeado de muitas camadas, abordaremos alguns dos recursos mapeados na conformação de Em um corpo só. ${ }^{340}$

$\mathrm{Na}$ coleta de materiais estão procedimentos práticos que visitam as mais variadas fontes, remetendo ao caráter transdisciplinar que o aprendizado e a criação de um ator pode assumir. Dos meus diários de trabalho, selecionei imagens, epígrafes, partituras anotadas, músicas que inspiraram a dramaturgia física e vocal. Na colagem das ações, trabalhei sobre os recortes, tanto de texto quanto de movimentos, aplicando a cada um várias partituras e escolhendo o que deveria ficar como ação para cada trecho do texto. Partes das estruturas da cena Em um corpo só, apresentada em $2010,{ }^{341}$ serviram à nova montagem. Do "cartão de visita" que apresentei na Arte Secreta do Ator-Brasil, Brasília, 2010, aproveitei materiais para a cena aqui trabalhada, considerando fragmentos de texto lá apresentado e as orientações que anotei de Barba e Varley sobre aquele material.

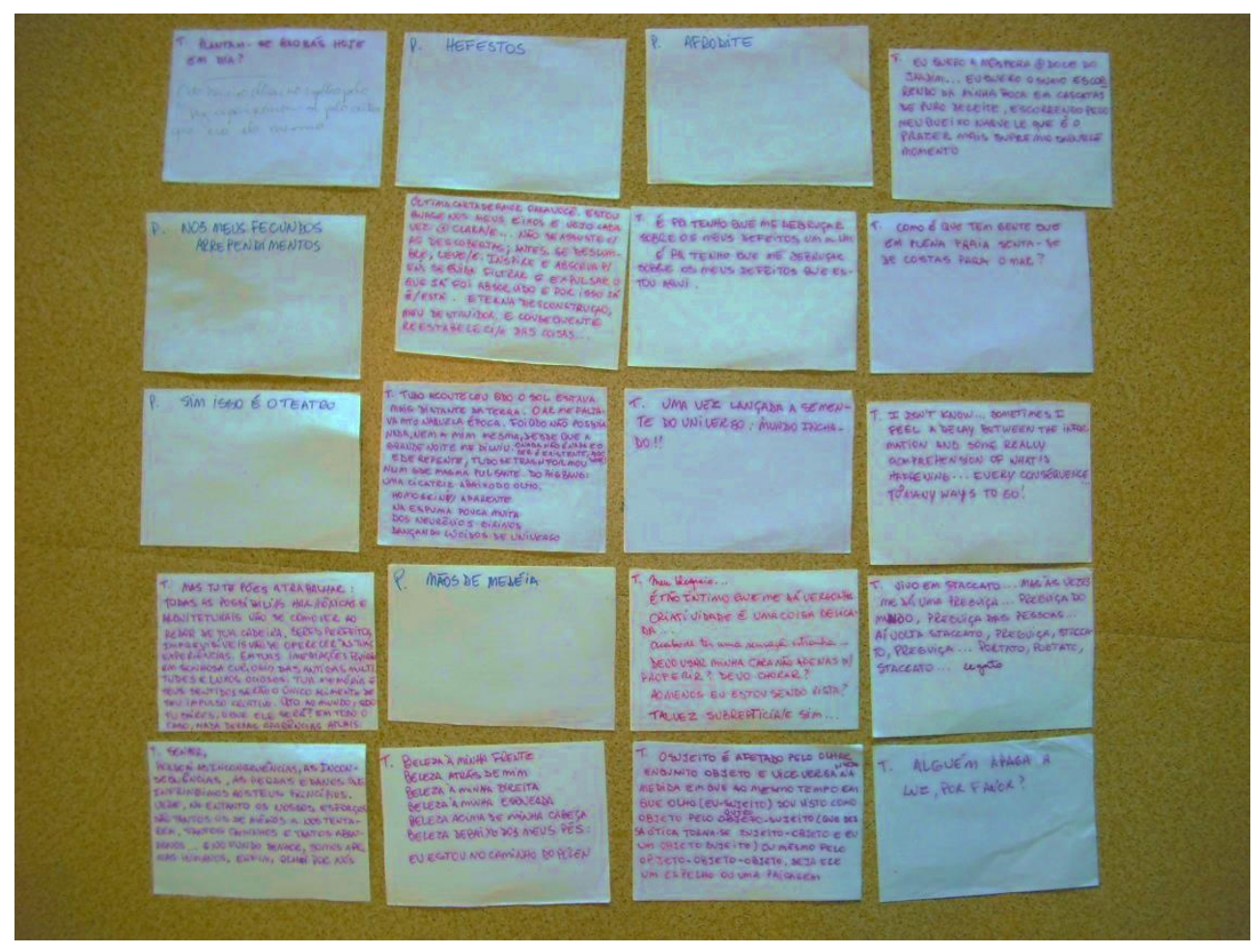

Figura 33. Fragmentos de textos. Foto: Leticia Olivares, 2010.

\begin{abstract}
${ }^{340} \mathrm{O}$ processo foi documentado principalmente em anotações nos "diários de bordo". Na transcrição para a dissertação, os recursos do computador serviram para organizar a notação do processo, ganhando relevância na forma que a escrita assumiu, a ver em 4.2.1. A gravação em vídeo foi utilizada pontualmente, em treinamentos e quando achava que tinha algum resultado cênico. Houve muitos apontamentos em áudio, facilitados pelo recurso do telefone celular, para insigths que ocorriam quando estava em trânsito ou outros momentos que não estava na sala de ensaios ou frente ao computador.
\end{abstract}

${ }^{341}$ Ver n.r. 330, p. 181 deste trabalho. 
A partir de materiais retirados de fontes heterogêneas como diálogos de filmes de Woody Allen, textos de diversos autores, como Cocteau, Beckett, ${ }^{342}$ Lewis Carroll, Sophia de Mello Breyner Andresen e de minha própria autoria, se deu a dramaturgia textual da cena Em um corpo só.

Aconteciam improvisações a partir dos textos, que me levavam a reações às palavras. O problema dessa estrutura é de muitas vezes cair na ilustração, portanto, tentava perceber o impulso daquela ação espontânea que o texto havia me provocado e o transferir para outra partitura física, casando ação e intenção diferentes.

Reconhecer minhas tendências no treinamento serviu para escolher propositadamente contrapontos ou reafirmações. Como o grande e o forte, que se destacam em minhas improvisações, substituído pelo pequeno e suave. A certa altura dos laboratórios, tomei a opção pelo princípio da omissão/redução de todas as partituras e isso se deu por dois fatores: 1. O entendimento de que as partituras não são em si resolução cênica, mas sim o pretexto das ações que podem ou não ser visíveis ${ }^{343} ; 2$. O respeito a um corpo (o meu) que possui lesões crônicas relacionadas ao desgaste a que foi submetido durante anos e à idade em que me encontro, já com o ônus dos anos e estilo de vida pesando sobre as capacidades de movimentação. Esta constatação foi dolorosa e reveladora. O como meu corpo - acostumado ao extremo da execução física e aspirante de um ideal de movimentação plástica - relacionouse com os limites, levou-me a uma luta constante entre a frustração de que deveria fazer mais e o que realmente conseguia fazer. ${ }^{344}$ Então, experimentei a estratégia contida no princípio adotado para ressignificar o antigo conhecimento e entendimento sobre expressão. O princípio da redução serviu para prestar atenção às menores mudanças de tonicidade do tronco

${ }^{342}$ Falas da personagem de Diane Keaton, uma autora em crise de criatividade, no filme Interiores (1978), de Woody Allen; O Mentiroso, de Jean Cocteau (1889-1963), falas de personagens do filme de Beckett on film (dir.Michel Colgan, prod. Alan Moloney, 1999).

343 Nesse entendimento também brilham observações de Barba ("conter a exuberância e os movimentos grandes”- anotação pessoal. A Arte Secreta do Ator - Brasília, 2010), Varley e colegas que assistiram a fragmentos da pesquisa cênica, como Luciana Martuchelli, durante o curso de Roberta Carreri em São Paulo (2013), que comentou sobre uma parte específica da minha cena em que eu trabalhava justamente a redução, mantendo apenas o impulso interno, como a mais potente.

344 Além disso, sobre as dificuldades, em minhas anotações nos diários, saliento: manter a constância do treinamento; recuperar na repetição as qualidades achadas nas improvisações; vigor físico; capacidade de autoestímulo; autocrítica excessiva; dramaturgia textual, como costurar tudo o que eu queria dizer?; porque dizer tais coisas?; a quem estou me dirigindo?; achar a "persona", quem está falando?; abrir o processo para espectadores. 
(BARBA, 2010b, p. 70) nas ações que compõem minhas partituras físicas, tornando-as assim também subpartituras, que contêm os impulsos físicos, as imagens, associações pessoais etc que as compõem em seu conjunto.

A escolha da persona, a mulher-foca, emergiu de anotações antigas sobre o mito Pele de foca, pele de alma, narrado no livro Mulheres que correm com lobos (ESTÉS, 1992, p. 323). Quando retomei a "persona mulher-foca" neste trabalho, muito me surpreendi ao lembrar que era um mito nórdico, das terras geladas onde está o Odin Teatret. Também foi interessante notar como a personagem, em minha versão na cena e apreensão do mito, havia se encaminhado. Interessou-me principalmente a análise da autora também psicóloga junguiana que reuniu os mitos e histórias nesse livro (ESTÉZ, 1992, p. 333):

Perdemos a pele da alma quando ficamos muito envolvidas com o ego, quando nos tornamos por demais exigentes, perfeccionistas, quando nos martirizamos desnecessariamente, somos dominadas por uma ambição cega ou quando nos sentimos insatisfeitas - com o próprio self, com a família, a comunidade, a cultura, o mundo - e não fazemos nem dizemos nada a respeito disso, também quando fingimos ser uma fonte ilimitada para os outros quando não fazemos o possível para a gente. (Estéz, 1992, p. 333)

Paira, sobre mim e a persona escolhida a angústia da criação, a expectativa de "corresponder" ao que é esperado, o treinamento, que levou a me deparar com limites, a procura da pele metafórica e a aspirada "volta ao lar"345 que se dá na cena, ao colocar-me em jogo com toda a estrutura criada, como as partituras e subpartituras e a fragilidade entre o que domino e o que não domino, e, sobretudo, com o desejado confronto com o Outro. A construção se dá entre entrar e sair da persona, no embate entre a pesquisadora, a atriz e o olhar do espectador.

Interessam-me, na cena, o jogo entre o que é e o que parece não ser ensaiado, as "iscas ósteomusculares" que aciono, de acordo com minhas partituras/subpartituras e o tempo de reação do meu corpo na propagação (ou não) para o movimento externo projetado no espaço e em relação com o dentro-fora, considerando o diálogo estabelecido com o momento presente em que todas as construções se revivificam, atualizando-se.

A repetição, como já observamos, gera dificuldades que exigem procedimentos de resgate, fazendo a vez de uma "ancoragem" dos materiais conquistados e, neste caso,

345 “O lar é a pura vida instintiva que funciona tão bem quanto uma engrenagem bem azeitada, onde tudo é como deveria ser [...].” (ESTÉZ, 1992, p. 357). 
organizar o processo na escrita para a dissertação tornou essa fase da pesquisa o meu diário de bordo e fez parte da criação em si.

\subsubsection{Notação da composição cênica: EM UM CORPO SÓ}

Apresento a grafia da cena em notação subjetiva, pensando-a também como parte das materialidades e sentidos, do visível e do invisível, pelos quais se trafega em uma criação. Apoiada em recursos gráficos disponíveis no programa de um computador como cores ${ }^{346}$, imagens e tachados, a escrita é, por si mesma, uma construção do diálogo entre os impulsos para a encenação e seu registro concomitante, apesar de editado para a versão final aqui apresentada.

Há partituras nomeadas que são incompreensíveis para quem lê, como "partitura Afrodite", às quais me eximo de descrever em detalhes, mas que dizem respeito a materiais incorporados e contêm várias ações implícitas em uma lógica pessoal da atriz. Apenas para exemplificar, acrescento a transcrição de uma partitura, que também uso na cena, desenvolvida no curso de Carreri (2013), com base nas ações (grifadas) que essa atriz propõe em seu treinamento:

1. Lançar para lado/baixo; junto com basta do pé;

2. Um passo/ desequilíbrio peito;

3. Olhar para diagonal esquerda, apontar com braço/mão esquerda;

4. Chamar grande, de trás para frente;

5. Passo com pé direito, pisar na pedrinha;

6. Parar com espera/parar mãos atrás, embaixo;

7. Ouvir, lado direito/ desequilíbrio cabeça /girar;

8. Apontar para cima, perto do ouvido direito;

9. Mão direita parar/espera acima;

10. Mão direita lança suave para baixo;

11. Desequilíbrio quadril lado direito, girar meio corpo;

12. Apontar para baixo dedo esquerdo;

13. Abaixar;

\footnotetext{
${ }^{346}$ A cor vermelha, em geral relacionada graficamente a correções de erros, é aqui adotada pelo destaque que proporciona, dando importância ao que se deseja salientar, ou seja, as ações.
} 
14. Parar mãos lateralmente ao corpo, lado direito;

15. Chamar como se juntasse algo;

16. Chutar;

17. Estátua art noveau.

Na liberdade de escrita adotada a seguir, registra-se um caminho particular no trabalho da notação para a partitura e subpartitura, considerando que esta última contém imagens, peripécias, desejos, partes, mais uma vez, da lógica pessoal que conduziu minhas escolhas na seleção e montagem do material.

\section{INSPIRAÇÕES: ${ }^{347}$}

"Digo: o real não está na saída nem na chegada: ele se dispõe para a gente é no meio da travessia" Guimarães Rosa, 2001, p. 80.

"Há uma escada/ a escada está sempre ali/inocentemente suspensa/junto à lateral da escuna... Nou descendo/vim explorar os destroços... vem ver os danos sofridos/ e os tesouros que restaram. Adrienne Rich apud Estéz, 1992, p. 357

"Rede sobre um abismo de forças escuras e luminosas..." Barba, 2006, p. 13.

“Dançar sobre a ponta de uma agulha” (idem, 93).

“[...]ultrapassagem de todas as formas, jogo de aparências, confusão entre o ilusório e o real, a alteridade de Dioniso depende do fato de, através de sua epifania, todas as categorias ressaltadas, todas oposições nítidas que dão coerência à nossa visão de mundo, em vez de permanecerem distintas e exclusivas, se aproximam e se fusionam, misturando-se umas às outras.” Neto, 1994, p. 84.

Usar a corporeidade a serviço das sensações tomando o corpo como um conjunto de significações vividas. Formulação baseada pela leitura da Fenomenologia da Percepção de Merleau-Ponty, em 2009.

${ }^{347}$ Provindas de anotações nos diários. 
Apropriação como diálogo contemporâneo. Ou qualquer outra relação com os gêneros, filosofias; não negando a interpretação como fator também de diálogo com a "realidade". Porém, sem manter circuitos fechados de informação que prejudicam o desenvolvimento. (Anotação pessoal em folha solta, s/d).

Ambiente:

Redes penduradas, redes com coisas dentro. Pedras e conchas pelo chão. Uma mesa e uma cadeira giratória. Uma luminária. Computador. Caixas de som. Móvel com livros em cima. Um vaporizador.

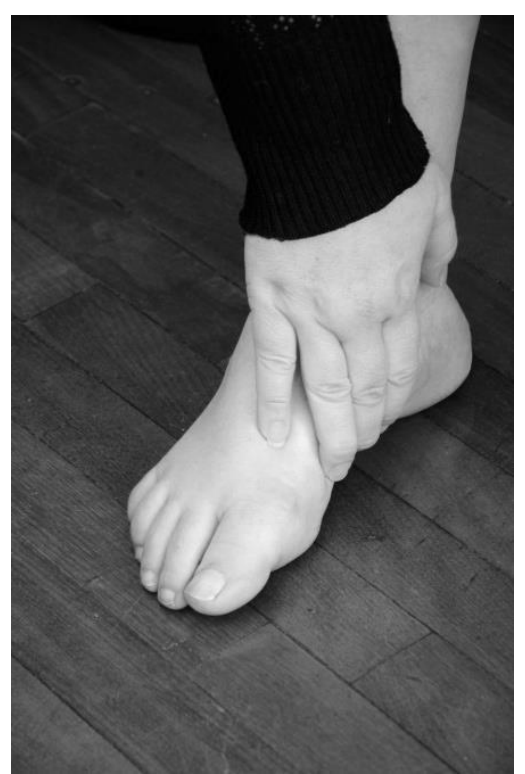

Figura 34. Ensaio de EM UM CORPO SÓ. Foto: Fábio Reginato. São Paulo, 2014.

AÇÕES/PARTITURAS: Ela vai saltando entre as conchas, às vezes as pega e coloca na reupa, cabelo, orelha, belses.... Sentada na cadeira, passa um gel nas articulações: pé esquerdo, pé direito, joelhos (esq/dir), ombro direito. Som com harmônicos/ SUBPARTIRURA: o grito da prata, o som da risada da onda quando bate na pedra.

a) (partitura Afrodite-reduzida) TEXTO: O meu bloqueio começou no ano passado (isca = desequilíbrio pelo quadril). Minha paralisia (levar água salgada à boca). (olha para esqueleto coberto) Comecei a ter pensamentos sobre a morte (tapa na cara, leve). Sobre o que significa morrer. Sentimentos de frustração com relação ao meu trabalho. Afinal, o que eu quero tanto (consoante c/k) criar? Criatividade é uma coisa delicada!/ Esse é um texto de Diane Keaton no filme... de Woody Allen, qual é o filme de woody 
allen mesmo em que ela fala isso? (Apoia-se na mesa, menção ao pensador) Tem que entrar na bibliografia... Nota mental: texto do filme de Woody Allen, ver nome e data.

b) (quebra/lendo na frente do computador/ partitura vai se construindo aos poucos, passando do corpo cotidiano a um estado diferente de tensão) Tudo aconteceu quando o sol estava muito distante da terra. $\mathrm{O}$ ar me faltava muito naquela época. Foi quando não possuía nada, nem a mim mesma, desde que a grande noite me diluiu. Foi quando tudo se transformou num grande magma, não grande de novo não pode. Desde que a noite escura. Não. Foi quando não possuía nada, nem a mim mesma, desde que a grande noite me diluiu. Foi quando tudo se transformou (basta com mãos) num magna pulsante depois do Big Bang, que adquiri essa cicatriz embaixo do olho. E na homogeneidade aparente da espuma dos neurônios-girinos, dancei, lúcida de universo. (Impulso costelas abre braço esquerdo- solta a música. Cegos do Castelo- NANDO REIS, mão direita)

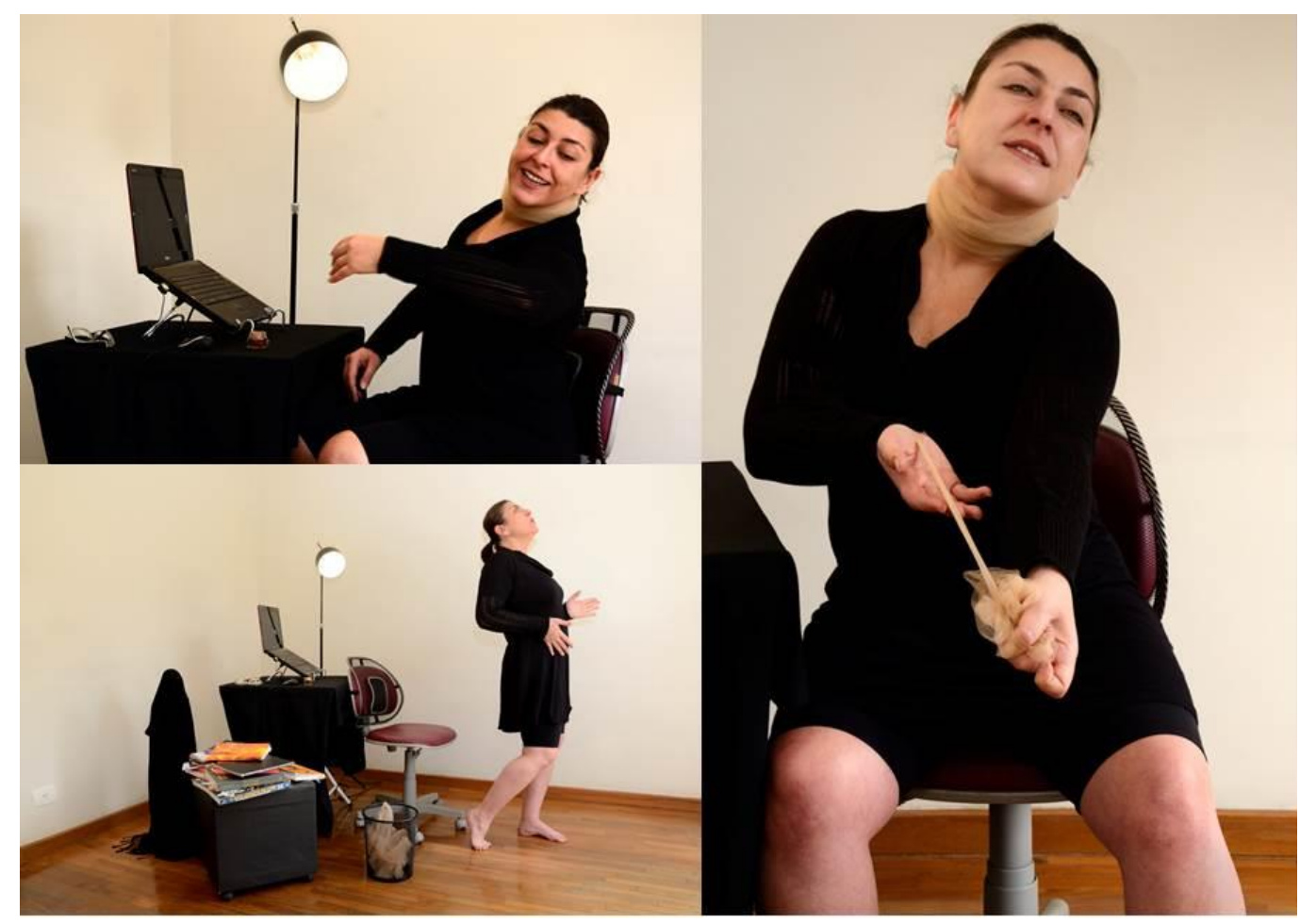

Figura 35. Ensaio de EM UM CORPO SÓ. Fotos: Fábio Reginato. São Paulo, 2014.

(Volta a dançar a dança da mão e braço esquerdo, projetando sua dança no espaçoAfrodite - quando vai pro chão e se levanta) (Braço vem redondo para frente e faz um arco com o outro/arrepio/) UM CAMINHO UM LUGAR PRO QUE EU SOU. 
(desliga a música) Pro que eu sou. (retoma braço, o outro vem, arrepio: contração pelo cóccix)

c) (storytelling: fogueira- Mãos à frente, entre as pernas, seguram a cadeira) Havia uma praia e um pescador. Todas as manhãs o pescador saía para pescar sem saber que no mar morava a mulher-foca. (puxar/descolar a pele-braço esquerdo) Certa vez, ao puxar sua rede, com ela veio a mulher foca (pele vira MF). Ao ver seus olhos grandes redondos, o pescador se apaixonou imediatamente. (puxar/descolar braço direito) A mulher foca também se apaixonou pelo pescador e decidiu tirar sua pele de foca para poder se casar com ele (junta as duas peles como se fossem eles). (mãos na boca- alto) Juntos se amaram ardentemente. (baixinho) Juntos tiveram um filho. Juntos ficaram por muitos anos (alisa as duas faixas de pele verticalmente, amarra-as,/quebra, em segundos procura algo para colocar a pele, vê o cesto de lixo, põe à sua frente, entre suas pernas/começa a tirar a pele do pescoço, põe no cesto) Porém, a mulher foca sentiu que começara a ressecar... perdia o viço dos olhos e da pele, então,

d) O que aconteceu com a mulher? (volta-se para o computador) No conto original, o homem rapta a pele da mulher foca e a esconde, impedindo-a de voltar para o mar. E o que acontece com essa mulher foca?

e) (cadeira giratória, levanta-se, isca = quadril/pés, Nijisnky,

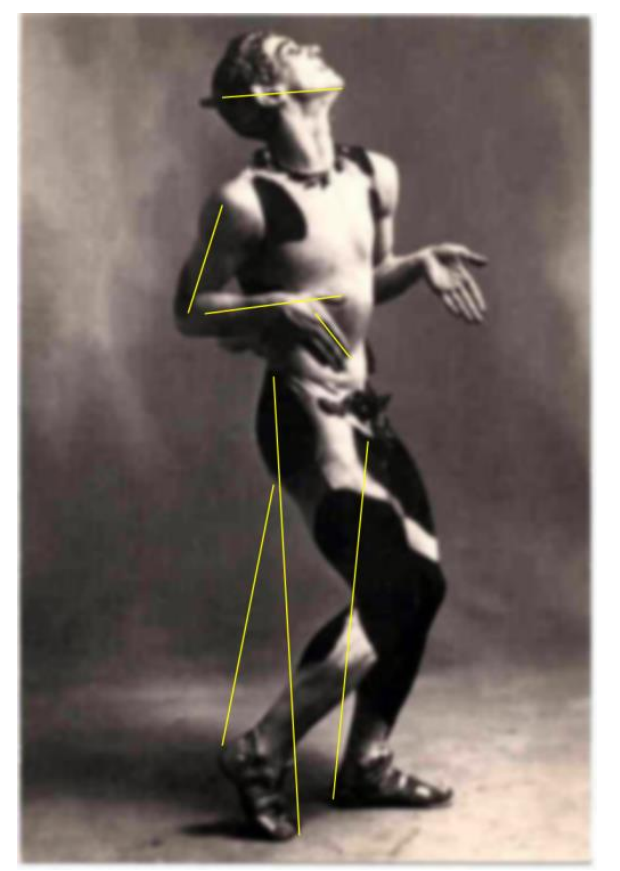

Figura 36. Nijinsky. L'Après-midi d'un faune. ${ }^{348}$

${ }^{348}$ Segundo informações colhidas na internet, essa foto foi feita pelo Barão de Meyer que "documentou o jovem bailarino em fotografias posadas de grande sensibilidade: as fotografias encontram-se reproduzidas (SHEAD, 1989)". Disponível em: 
Andando/ isca=joelhos)

f) Será que ela já está um pouco tresloucada? Talvez, sub-repticiamente, sim.

g) (Intenção de voltar para o computador/ meio giro rápido, volta para onde estava) (É tão íntimo que me dá... Afrodite)

h) (Partitura 2010, isca=introversão do externo/antebraços levantam) ACABO de ter uma sensação estranha! É como se eu sentisse todo meu corpo. Senti meu sangue correndo em minhas veias, mãos e nuca... (cotovelos fecham close no rosto, isca=estômago) Devo usar meu rosto não apenas para proferir? Devo chorar? Talvez... (cotovelo leva ação do giro, torção no tronco, isca=costelas)

i) (cotovelo para o céu, falando com um suposto Deus, ressonador:boca) Ao menos eu estou sendo vista? Talvez, sub (baixa o tom, ressonador ventre; procura o "rrrepticiamente", isca=contraction) rrrrepticiamente , repticiamente, (ressonador: cabeça) sim!

j) (Partitura 2010, isca= desequilíbrio quadril lado, marionete) Por exemplo, o sujeito é afetado pelo olhar como objeto, e vice versa, ou seja, na medida em que olho, eusujeito sou vista como objeto pelo objeto sujeito, que por sua vez se torna um sujeito objeto, mesmo sendo um objeto/objeto, ou seja, um espelho ou uma paisagem. E viceversa./

k) Bom, tem texto do filme do woody allen, mas tem do Beckett também, NOT I. Nota mental, filme de woody allen e texto de beckett, ver nome e ano. Se bem que esse último é meu... baseado em merleau-ponty, tá.

1) OU... (espiral para lado esquerdo, isca=costelas, para o céu) Tudo, tudo isso será apenas um jogo? (atenção, resposta vem da concha no chão, isca=orelha esquerda, pega a concha, ouvindo)

m) (ressonador: peito) Então o nada é o nada e o ser é existente, pode ser? (pousa a concha no chão, abre espaço com as mãos) Eu não quero mais mentir.

n) (entra no espaço, isca=desequilíbrio joelhos, imagem: afundar em areia fofa) Eu queria dizer a verdade. Adoro a verdade. Mas ela não gosta de mim. Eis a verdadeira verdade. (firmar os pés, todo o texto partitura 2013) A verdade não gosta de mim. Logo que a digo ela muda de figura (partitura Afrodite: tapa na cara) e volta-se contra mim. (de lado, cabeça volta-se um pouco para o centro, olhar vai mais) Tenho cara de mentirosa e todos me olham de esguelha. (pega no vestido- Maria caipira, ressonador: 
boca) Mas sou simples, juro. E detesto a mentira. (ressonador: peito) A mentira sempre provoca coisas horríveis! (abre espaço com os pés chutando algumas conchas) Você enfia os pés pelas mãos, tropeça, cai e (:) todos se riem de você. (:D) Quando me perguntam alguma coisa, quero responder o que penso, quero responder a verdade. (afundando o peito, isca=externo) Mas aí, não sei o que se passa... sou tomada de uma angústia, um medo do ridículo, e (ressonador: cabeça) minto, pronto, (ventre) minto. (peito) E uma vez o pé na mentira (pisa em uma concha, quebrando-a, reação), (cabeça) tarde demais para se voltar atrás. (peito) E não é cômodo, juro-lhes. Por exemplo,(isca=punhos) se amo, digo que não amo e se não amo digo que amo, imaginem a confusão. Mais vale é dar um tiro na cabeça! (mão no estômago, vai para a cabeça, sensual) Mas não, é inútil colocar-me na frente do espelho e repetir: (mão de revólver, empurra pela têmpora esquerda, isca=oposição mão/cabeça) você não mentirá mais, (escorregando arma pelo rosto, enfia dentro da boca) não mentirá mais, (desce para o peito, batendo com o "cano" no coração) não mentiráá... (aumentando as batidas, deixa influenciar a voz, abaixa-se, isca=oposição cóccix/cabeça) minto, minto, minto. Minto nas pequenas coisas e nas grandes/ corta batidas/ também. (pega uma concha e escreve no chão) E se acontece de eu dizer a verdade, ela se vira do avesso, se encarquilha toda e vira mentira (concha segurada na mão como se fosse piolho, joga fora, levantando). Eu não sou má, sou até boa. Mas se me chamam de mentirosa, o ódio me sufoca. (cabeça) Eu sei que mereço o insulto; mas o que me dói (ventre) é que não compreendam que eu minto contra a minha vontade. (sapateando involuntariamente, isca=calcanhar) É o demo que me instiga (OLÉ) (banho de cachoeira-) Ahhh, vou mudar (saudação final - Sayô). Pronto, já mudei. Me libertei do quarto desarrumado que é viver na desordem da mentira. E posso provar-lhes./

o) Não, tenho vergonha, detesto minhas mentiras... E vocês, será que mentem? Ah, com certeza mentem, todos vocês. A gente mente. Eu por exemplo, menti quando disse que mentia. Não era verdade. Eu não minto. Eu não minto nunca. Eu detesto a mentira. Menti somente quando lhes disse que mentia. Agora ousem desmentir-me. Ousem me chamar de mentirosa. O quê? Ninguém diz nada? Ninguém quer me chamar de mentirosa? Ousem! Eu sabia! E fácil acusar os outros. Fácil deixá-los mal colocados. Vocês dizem-me que minto e, afinal, são vocês que mentem. É admirável. Eu nunca minto. Ouvem? Nunca. E se me acontece mentir, é para prestar um serviço... para evitar fazer sofrer... para evitar um drama. Mentiras piedosas. E claro que é forçoso mentir. Mentir um pouco... de tempos a tempos. O quê? Eu menti? Por certo, menti ao 
dizer-lhes que mentia. Mentirosa, eu? No fundo, já não sei. Sinto-me confusa. Que mundo o nosso, já dizia Cocteau em... (isca=desequilíbrio peito, vai para o computador)

p) (No computador, senta-se- lendo) Uma relação só pode existir se você for vc e eu for eu. Se você é você e eu não sou eu. Eu não sou. (vira-se para onde estão as peles) $\mathrm{A}$ mulher foca não é mais ela, então ela tem que partir. (abre o livro do coração- 12 batidas - pega a pele, pega outro livro- Cieslak; Medéia: peito) Filho a mamãe vai ter que ir embora. (isca=cotovelos, beija o livro, leva ao coração. Embrulha a "pele" no livro, deposita-o na mesa, pega outra pele)

q) (levanta-se, isca=coxo-femural esq., vai até onde o esqueleto está escondido, descobreo - lenço na cabeça- Salomé; passa outra pele sob os braços do esqueleto.) (peito) Qual a crença, é a doença. (cabeça) Curioso, minha doença não dói. (peito) Minha doença só corrói o âmago do ser, pois me leva estar aonde não devia, falando coisas inadequadas, sentindo o que não sinto. (anda com ele) Como eu gostaria de estar nas praias brancas e quentes do Nordeste, livre e feliz.

r) (Senta o esqueleto em seu braço, como uma marionete, manipula sua boca, ressonador boca/ventre) Alice/atriz: Podes me dizer, por favor, que caminho hei de seguir a partir daqui? Gato/esqueleto: Isso depende muito de do sítio aonde queres chegar. Alice:

Não me preocupa muito aonde vou chegar. Gato: Então, não interessa por que caminho tu seguirás.

s) (dança valsa com o esqueleto, partitura 2010; homenagem a Varley - Castelo de H. isca=pés; nuvens) Mas quando a morte chegar hás de com ela dançar, e então...

t) Serei eterna. (pousa esqueleto sentado entre as conchas, isca=espiral para sentar)

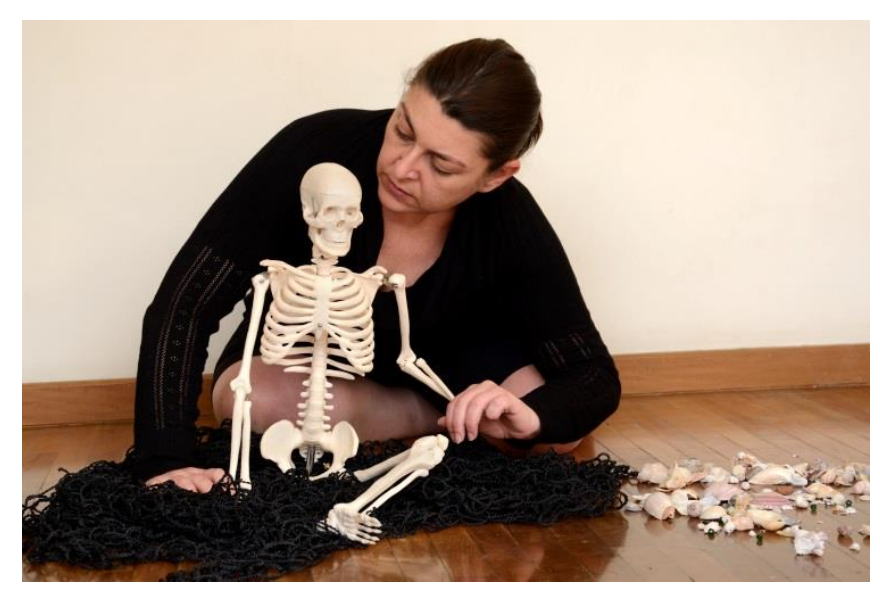


u) (como se estivesse no computador, digita) CAROLL, Lewis. Alice no país das....

v) Figura 38. Cena do filme O Labirinto do Fauno. Dir. Guillermo del Toro (2006).

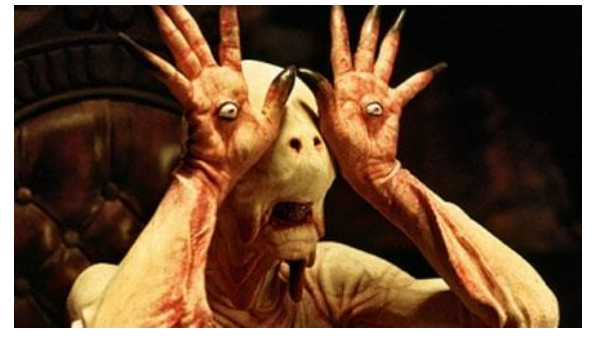

(peito) É porque pertenço à raça daqueles que mergulham de olhos abertos (espécies primitivas vivendo no oceano escuro e geladoanêmona na coluna=isca, ventre) E conhecem o abismo pedra a pedra, (peito) anémona a anémona, (cabeça) flor a flor" (vuuu, "som de um único átomo é um dos sons mais suaves fisicamente possíveis")

u) (engatinhando até se levantar, isca=topo da cabeça; computador) É isso! Eu quero falar do acúmulo de teorias e práticas em um corpo que se engaja em estabelecer conexões, permitindo encontros que comunguem em um processo de descoberta de caminhos, na pretensão de que o diálogo torne-se tão imbricadamente indissociável, que solucione em si, pela permissão do acontecimento, a execução do que se propõe.

v) (para plateia) De quem são esses olhos que me veem enquanto eu penso?

w) Alguém apaga a luz, por favor? (vai até a luminária, desliga-a)

FIM?

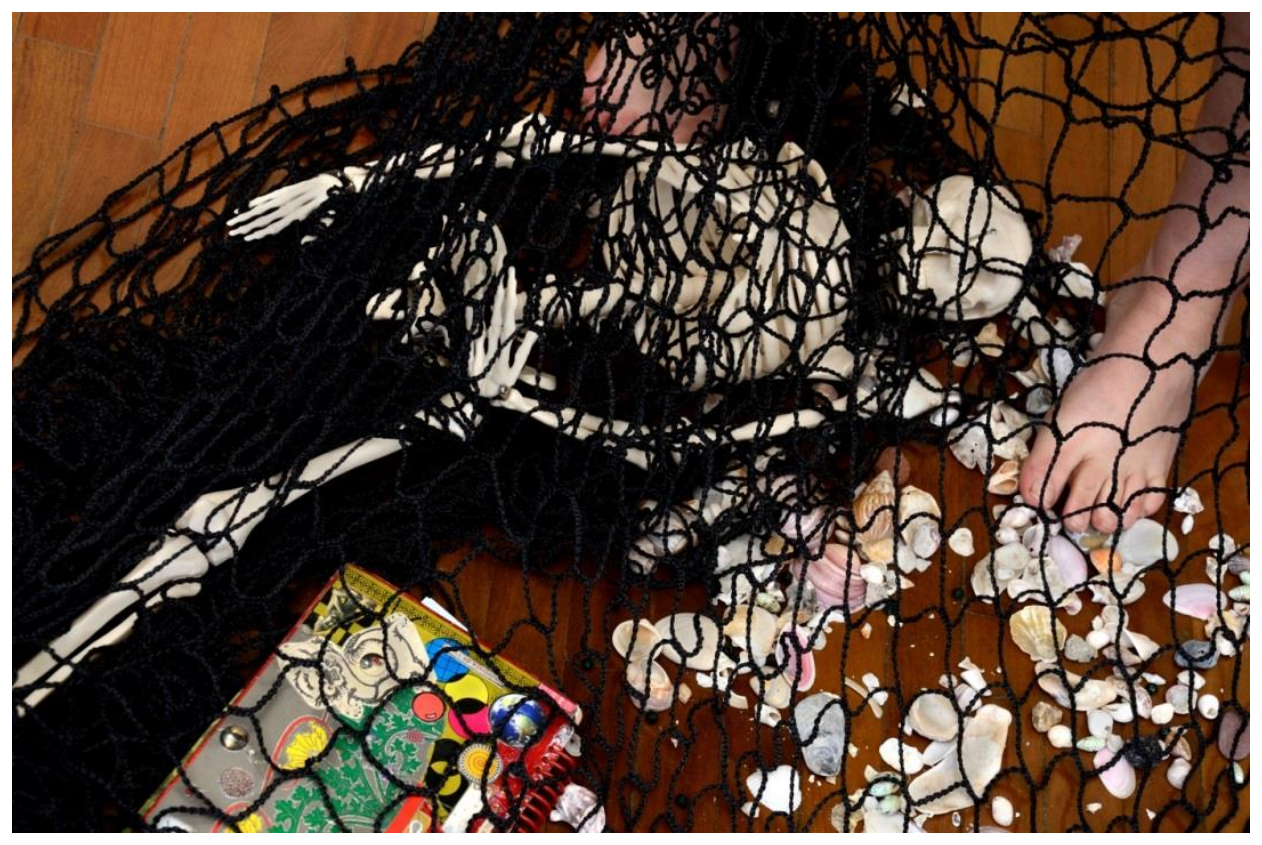

Figura 39. EM UM CORPO SÓ. Foto: Fábio Reginato, 2014. 


\section{CONSIDERAÇÕES FINAIS}

Não posso oferecer conclusões inovadoras sobre presença cênica, treinamento e tampouco sobre o que deve ser o trabalho do ator. Seguem-se, então, intuições, formulações que não visam fechar os assuntos, mas pontuar as trilhas seguidas e circuncidar pontos levantados neste estudo como a historiografia de um grupo, a metodologia autoetnográfica, a prática de treinamentos, o levantamento de materiais e a criação.

$\mathrm{O}$ ator precisa de pertencimento. Precisa sentir-se dentro de algum projeto, grupo, encontro onde possa trabalhar e se descobrir. O encontro com o Odin Teatret serviu-me de guia para um ideal de pertencimento o qual farejei em minhas experiências no Brasil. Como um grupo, formado de vários "eu” fortes que conseguem também ser "nós” aliados, alimentou minha coragem como artista e pedagoga. O Odin Teatret é uma ilha de respiro, em que reconheço um legítimo esforço de resistência baseado em suas ações nem sempre rentáveis, apesar de o fazerem mesmo assim. Isso não dispensa os milhares de euros que recebem por serem o Odin, nem compensa todo o esforço de serem $O$ Odin, mas estabelece, de alguma forma a possibilidade de existência (e resistência) de, por 50 anos, manterem-se como um grupo estável e produtivo. Uma ilha flutuante e tangente em que individualidade e coletivo têm espaço, e vem conseguindo, há anos, manter sua chama acesa e passar a pira para quem quiser receber esse calor e a carregar com o esforço exigido aos atletas que a mantém em movimento eterno. Penso em Eugenio Barba falando em duas palestras diferentes, uma em São Paulo e outra em Brasília, ambas em dezembro de 2012, sobre uma temperatura interna, um jaguar que temos dentro do estômago e que precisa dar à luz a uma força para ajudar a si próprio e, quiçá, ajudar os outros. O Odin Teatret tem trabalhado incessantemente na contribuição para sistemas que sempre estarão inacabados, pois são, por si sós, móveis e permeáveis, transversais e ilimitados na possibilidade de pesquisa e aplicação, em um lugar no qual o talento beira a teimosia por aqueles que têm o jaguar dentro de si.

Feitas tais considerações, entornando a história e a admiração pela mesma, penso, particularmente na herança para o ator.

Não há conforto em formulações sobre a técnica no ofício do ator. "No final das contas pode-se estudar o teatro?" pergunta Pavis. E ele mesmo responde que o teatro assume aspectos de "modelização e espelho deformante do mundo", "prestando-se a todas as 
questões, todas as abordagens, a todos os desejos de conhecimento, a todos os recortes do saber e da pesquisa.” (2008, p. 151-152; itálico do autor).

Reconhecer uma linguagem e visão de mundo através da arte me parece pertinente em um mundo fragmentado com o nosso. As metáforas que criaram na prática para o entendimento da técnica ajudam exemplificar sensações, descobertas e aplicações. A linguagem do ator que conseguiram mapear, inventar e organizar, cada um à sua forma, e que muitas vezes é sintetizada no nome de Barba, serve à facilitação pedagógica pela objetividade dos princípios.

O treinamento como tradição na preparação do ator é passado de forma clara por esses atores e atrizes que durante anos executaram o ofício de forma intrínseca à sua vida. Os princípios são objetivos e os procedimentos pelos quais alcançaram esses princípios são sua tradição ainda transmitida. A pergunta que fica é: do que te serve isso tudo? Não há fórmulas, muito menos a garantia de que adquirirá qualidade artística se repetir os exercícios. Mas há pontes construídas para ajudar o ator a praticar os princípios mapeados por um campo de estudos pautado no fazer e no reconhecimento deste fazer. A maestria é consequência da dedicação. E a possível transgressão de paradigmas consiste em conhecer os mesmo e os burlar.

Através de estruturas colocadas pelos mestres, é preciso avançar, com os próprios pés sobre um terreno que foi mapeado, mas que também exige, por já ter sido muito pisado, novas pontes a serem (re)construídas. O treinamento apesar de muito objetivo, na preparação préexpressiva (lembrando-a como plataforma), semeia o campo para que o mundo interior do ator seja também recurso em seus momentos de criação. O método, então, como algo inventado ou organizado por alguém, é transmitido como forma de conhecimento a ser incorporado e para ser conduzido além de si, estabelecendo novas conexões e possibilidades.

No percurso autoetnográfico, confrontando anotações com a bibliografia, deixo um panorama de referências sobre as fontes. Descrições que espero servirem a alguém. Muitas controvérsias me surgem a respeito de noções historiográficas que esta narração pode assumir e também nos conflitos entre "história", que faz sempre parte de um ponto de vista de quem a conta, e o que vivenciei presencialmente. Durante a pesquisa, questões sobre o papel de observadora, a função do artista na contemporaneidade e a fala a partir do eu, sobre o próprio 
processo foram tangentes e continuam instigantes a mim. Creio que sejam janelas que esta pesquisa deixa.

Não existe fórmula. Existe uma disponibilidade para o fazer. Lançar-se na vulnerabilidade da criação com toda a sabedoria adquirida, mas com humildade para saber onde o processo te levará. A procura torna-se o próprio achado e a busca é alimentada por profissionalismo, aprimoramento e um grande sim, que deve vir disfarçado de muitos nãos, para que não nos acomodemos em facilidades óbvias e traspassemos os muros criados.

Relendo minhas linhas nesta pesquisa, percebo que a autonomia é feita de muitas vozes, valorização de conselhos e capacidade de se expor.

Talvez, esta crônica de aprendizagem e contato com as tradições diga respeito somente a uma necessidade de entender escolhas e deslocamentos. Mas, no registro das vivências, espero fazer um sentido exterior a mim mesma, considerando a potência que experimentei ao viver cada exercício e aplicação. Potência esta que diz respeito ao que quero como artista e também como professora. É uma descoberta e redescoberta constante, a cada vez que é posta à prova e que não pode ser traduzida em palavras, por mais que tenhamos recursos linguísticos e científicos para explicá-la. Porém, a executarmos constantemente tange o inenarrável e o compromisso interno que só se pode alcançar dia-a-dia, na construção do irreal (ou do ideal) a ser narrado como artistas e transmissores do vivido/experimentado.

Na dificuldade de colocar um ponto final nesta dissertação, admito que o que existe são reticências no trabalho sobre si mesmo sem fim, que desafia certezas e resultados para manter o corpo em vida. 


\section{BIBLIOGRAFIA}

ANDREASEN, John, KUHLMANN, Annelis. Odin Teatret 2000. Aarhus: Aarhus University Press, 2000. P. 85. ISBN 87-7288-872-5

ARTAUD, Antonin. O Teatro e seu Duplo. São Paulo: Max Limonad, 1984.

AZEVEDO, Sônia Machado. O papel do corpo no corpo do ator. $2^{\mathrm{a}}$ ed. São Paulo: Perspectiva, 2008.

BARBA, Eugênio; SAVARESE, Nicola. A Arte secreta do ator. Um dicionário de Antropologia Teatral. São Paulo: É Editora, 2012.

BARBA, Eugênio. A Canoa de Papel: tratado sobre Antropologia Teatral. Tradução de Patrícia Alves Braga. Brasília: Teatro Caleidoscópio, 2009.

Teatro: Solidão, Ofício, Revolta. Tradução de Patrícia Alves Braga. Brasília: Teatro Caleidoscópio, 2010a.

. Queimar a Casa: origens de um diretor. São Paulo: Perspectiva, 2010 b.

A Terra de Cinzas e Diamantes. São Paulo, Perspectiva, 2006.

Barcos de piedra e islas flotantes. In: Revista Máscara, ano 4. No. 19-20 (Out1994/1995). México: Escenologia, A.C. p. 4-9.

BAUER, Martin W. e GASKELL, George. Pesquisa qualitativa com texto, imagem e som. Um manual prático. Petrópolis, Ed. Vozes, 2000.

BONFITTO, Matteo. O Ator Compositor. São Paulo: Perspectiva, 2002.

Entre o ator e o performer. São Paulo: Perspectiva: Fapesp, 2013.

CARRERI, Roberta. Rastros: Treinamento e História de uma Atriz do Odin Teatret. São Paulo: Perspectiva, 2012.

CHRISTOFFERSEN, Erik Exe. The actor's way. Londres: Routledge, 1993.

DEMO, Pedro. Desafios modernos de educação, 2. ed. Petrópolis: Vozes, 1993. Apud SIQUEIRA, F. et al. Como elaborar projeto de pesquisa: linguagem e método. Ed. FGV, 2008. Disponível em: <http://www.uff.br/sga/monografia/MATERIAL_U_ECO.pdf>. Acesso em 10/09/2012.

DIP, Nerina Raquel. Espetáculo solo, fragmentação da noção de grupo e a contemporaneidade. 137f. Dissertação (Mestrado em Teatro) - Universidade do estado de Santa Catarina (UDESC), Florianópolis, 2005.

Disponível em: <http://www.tede.udesc.br/tde_arquivos/2/TDE-2007-03-27T140246Z311/Publico/NERINA\%20DISSERTACAO.pdfm:> Acesso em: 02/07/2011.

ECO, Humberto. Como se faz uma tese. São Paulo: Perspectiva, 2012. 24 ed. (Estudos; 85).

ESTÉS, Clarissa Pinkola. Mulheres que correm com lobos. Mitos e histórias do arquétipo da mulher selvagem. Rio de Janeiro: Ed. Rocco,1992. 
FABIÃO, Elenora. Corpo Cênico, Estado Cênico. In: Revista contrapontos. v.10, n3. p. 321-326, 2010. Disponível em: http://www6.univali.br/seer/index.php/rc/article/view/2256. Acesso em: 23/06/2014.

FERNANDES, Adriana. Dalcroze, música e o teatro -fundamentos e práticas para o ator compositor. p. 17-22. In: FENIX REVISTA DE HISTÓRIA E ESTUDOS CULTURAIS. Setembro/Outubro/Novembro/Dezembro de 2010. Vol. 7 Ano VII n.3 ISSN 1807-6971. p. $17-22$.

FERRACINI, Renato. A arte de não-interpretar como poesia corpórea do ator. Campinas: Editora Unicamp, $2^{\mathrm{a}}$ ed., 2003.

. Os pais mestres do ator-criador. In: Revista do Lume, n.2, UNICAMP, Campinas S.P, 1999. p. 62- 76 Disponível em:

<http://www.cocen.unicamp.br/revistadigital/index.php/lume/article/view/180/172>. Acesso em: 15/03/2013.

. Atuações, fronteiras e micropercepções. In: Sala Preta, 2010, v. 10. Disponível em:

<http://www.revistas.usp.br/salapreta/article/view/57452>. Acesso em: 22/08/2014.

FO, Dario. Manual Mínimo do Ator. São Paulo: Ed. SENAC, 1998, p. 97.

FORTIN, Sylvie. Contribuições possíveis da etnografia e da auto-etnografia para a pesquisa na prática artística. In CENA n. 7, 2009. Periódico do Programa de Pós-graduação em Artes Cênicas Instituto de Artes - Universidade Federal do Rio Grande do Sul. ISSN 1519-275X. Disponível em: <http://seer.ufrgs.br/index.php/cena/article/view/11961/7154>. Acesso em 12/11/2013.

- Educação somática: novo ingrediente da formação prática em dança. In: Cadernos do GIPE-CIT: Grupo Interdisciplinar de Pesquisa e Extensão em Contemporaneidade, Imaginário e Teatralidade/ Universidade Federal da Bahia. Escola de Teatro, Programa de Pós-graduação em Artes Cênicas. Escola de Dança. n. 2, fevereiro de 1999. Salvador: UFBA/ PPGAC.

GUINSBURG, J., FARIA, R.J., LIMA, M.A. Dicionário do Teatro Brasileiro. Temas, formas e conceitos. São Paulo: Edições Sesc SP, 2009.

GREINER, Christine. O corpo. Pistas para estudos indisciplinares. São Paulo: Annablume, 2005.

O corpo em crise. Novas pistas e o curto-circuito das representações. São Paulo: Annablume, 2010.

GROTOWSKI, Jerzy. Em busca de um Teatro Pobre. Rio de Janeiro: Civilização Brasileira, 1976.

O Teatro Laboratório de Jerzy Grotowski, 1959 - 1969. 2a ed. São Paulo: Perspectiva/Edições SESC SP , 2010. El Performer. In: Revista Máscara, Caderno Iberoamericano de reflexão sobre Escenologia. Publicação trimestral de teatro, editada por Escenologia, A.C. Ano 3 n. 11 12. Ciudad del México: enero 1993. p. 76-79.

Tu Eres Hijo de Alguien. Ibidem. p. 69-75.

Resposta a Stanislavski. Ibidem. p. 18-26.

Sobre o método de ações físicas.

Disponível em <http://archive.today/PnOlY>Acesso em: 10/09/ 2013. 
GUMBRECHT, Hans Ulrich. Produção da presença: o que o sentido não consegue transmitir. Rio de Janeiro: Contraponto Editora PUC-Rio, 2010. . Graciosidade e estagnação. Ensaios escolhidos. Rio de Janeiro: Contraponto Editora PUC-Rio, 2012.

HASTRUP, Kirsten. The performer's village. Times, Thechiniques and Theories at ISTA. Copenhagen: DRAMA, 1996.

HEIDEGGER, Martin. Ensaios e conferências. 8. ed. Petrópolis: Vozes; Bragança Paulista: Editora Universitária São Francisco, 2012, p.27.

Disponível em: <http://gmeaps.files.wordpress.com/2014/02/martin-heidegger-ensaios-econferc3aancias-1.pdf> Acesso em: 15/11/2012.

ISAACS, Alan; MARTIN, Elizabeth (Orgs.). Dicionário de Música Zahar. Rio de Janeiro: Zahar Editores, 1981. In Imaginação, música e produção de sentidos: atividades criadoras em um contexto de musicoterapia com educadores PATRÍCIA Wazlawick Kátia Maheirie. Psicologia \&m foco Vol. 2 (1). Jan./jun 2009. Disponível em: <http://periodicos.piodecimo.edu.br/online/index.php/psicologioemfoco/article/view/40> Acesso em: 02/04/2013.

JIMENEZ, Sergio. El Evangelio de Stanislavsky. México, D.F.: Grupo Editorial Gaceta, 1990.

KORISH, David, The Mud and The Wind: an Inquiry into Dramaturgy, 2002, p. 284. In: New Theatre Quarterly, n. 71, v. 18 (3). Cambridge University Press. p. 284-289.

LAUKVIK, Else Marie. Do Miracles Happen? In: The open page. Holstebro: Odin Teatret Forlag, 1998. p. 25-28.

LECOQ, Jacques. O corpo Poético. Uma pedagogia da criação teatral. São Paulo: Ed. Senac, 2010.

LEHMANN, Hans-Thies. Teatro pós-dramático. Tradução de Pedro Süssekind. São Paulo: Cosac Naify, 2007.

MARIZ, Adriana Dantas. A ostra e a pérola: uma visão antropológica do corpo no teatro de pesquisa. São Paulo: Perspectiva, 2007.

MASGRAU, Lluís. Las peripecias del sentido o la ruta de los pajaros. In: MÁSCARA. Caderno Iberoamericano de reflexão sobre Escenologia. Publicação Trimestral de teatro, editada por Escenologia, A.C. Edição especial de Homenagem- 30 anos do Odin Teatret. Ano 4. N. 19-20. Outubro, 1994-outubro, 1995.p. 145-167.

Index of concepts in Eugenio Barba's writings. s/d, s/p. Disponível em: <http://www.odinteatret.dk/media/217060/INDEX\%20OF\%20CONCEPTS\%20-

Sept\%2010\%20-\%20en.pdf>. Acesso em: 01/03/2014.

MEYERHOLD, V. O Teatro de Feira. In: Na Cena do Dr. Dapertutto: poética e pedagogia em V.E.Meierhold:1911 a 1916. São Paulo: Perspectiva: Fapesp, 2009. . Le Revizor. In: Écrits sur le Théâtre - Vol. II. Trad., Pref. e Notas de Beatriz PiconVallin . Paris: La Cité - L'Age d'Homme. 1975. 
MERLEAU-PONTY, Maurice. Fenomenologia da Percepção. $3^{\text {a }}$ ed. São Paulo: Martins Fontes, 2006.

MIHUT, Anca Daniela. The actor's dramaturgy notes. In: STUDIA UBB DRAMATICA, LIX, 1, 2014, p. 71-95.

MORA, José Ferrater. Dicionário de Filosofia. Tomo IV, (Q-Z). São Paulo: Edições Loyola, 2004.

OIDA, Yoshi. O ator invisível. São Paulo: Via Lettera, 2007.

OKAMOTO, Eduardo. O ator montador. 163f. Dissertação (Mestrado em Artes) Universidade Estadual de Campinas (UNICAMP, Campinas, 2004).

Disponível em: <http://www.bibliotecadigital.unicamp.br/document/?code=vtls000361461> Acesso em: 05/07/2012.

PAVIS, Patrice. Dicionário de Teatro. $3^{\text {a }}$ Ed. São Paulo: Perspectiva, 2007.

Perspectiva, 2010.

A encenação contemporânea: origens, tendências, perspectivas. São Paulo: . Da Stanisllavskij a Wilson. Antologia portatile sulla partitura. In. DE MARINIS, Marco (org.) Drammaturgia Dell'Atore. Bolonha: I Quaderni del Ballello Ebbro. Teatro Eurasiano n.3, 1997, p. 63-81. Uma nozione piena d'avvenire: la sottopartitura. Ibidem, p.83-100.

PEREIRA, Sayonara. Rastros do Tanztheater no Processo Criativo de ES-BOÇO: Espetáculo cênico com alunos do Instituto de Artes da UNICAMP. São Paulo: Annablume, 2010.

PRODANOV, Cleber Cristiano e FREITAS, Ernani Cesar de. Metodologia do trabalho Científico: Métodos e Técnicas da Pesquisa e do Trabalho Acadêmico. 2. ed. Universidade Feevalle: Novo Hamburgo, RS, 2013. E-book disponível em: $<$ http://www.feevale.br/Comum/midias/8807f05a-14d0-4d5b-b1ad-1538f3aef538/Ebook\%20Metodologia\%20do\%20Trabalho\%20Cientifico.pdf $>$.

PUCCETTI, Ricardo. Parada de Rua - pequeno histórico e reflexões. In: Revista do Lume. UNICAMP-Universidade Estadual de Campinas/ LUME-Núcleo Interdisciplinar de Pesquisas Teatrais-COCEN-UNICAMP. Campinas, $n^{\circ}$ 4, ago 1999. p. 78- 84. Disponível em: Disponível em:

<http://www.cocen.unicamp.br/revistadigital/index.php/lume/issue/archive>. Acesso em: 09/07/2014.

RASMUSSEN, Iben Nagel. Il cavalo cieco: Dialoghi com Eugenio Barba e altri scritti. Roma: Bulzoni editore, 2006. p. 17-30.

As Mudas do Passado. In: Revista do Lume, n.2, UNICAMP, Campinas S.P, 1999.

Il Ponte dei Venti. Un'esperienza di pedagogia teatrale com Iben Nagel Rasmussen. Copenhagen: F. Hendriksens Eftf, 2001. Distribuizone in Italia: I Quaderni del Batello Ebro. ISBN 87-988459-1-8.

REY, Sandra. Por uma abordagem metodológica de pesquisa em artes. In: BRITES, Blanca e 
TESSLER, Elida (Orgs.) et all. O Meio como Ponto Zero - Metodologia da pesquisa em artes plásticas. Porto Alegre: Editora da Universidade/ UFRGS, 2002.

RISUM, Janne. Los actores del Odin. In: MÁSCARA. Caderno Iberoamericano de reflexão sobre Escenologia. Publicação Trimestral de teatro, editada por Escenologia, A.C. Edição especial de Homenagem- 30 anos do Odin Teatret. Ano 4. N. 19-20. Outubro, 1994-outubro, 1995. p. 31-59.

RUFFINI, Franco. De Volta à Sala Fechada: o meu diálogo com Jerzy Grotowski. In: Revista Brasileira de Estudos da Presença, Porto Alegre, v. 1, n. 1, p. 235-259, jan./jun. 2011. Disponível em: <http//www.seer.ufrgs.br/presenca> ISSN 2237-2660. Consulta em: 09/05/2013.

- A mente dilatada. In: A Arte secreta do ator. Um dicionário de Antropologia Teatral. São Paulo: É Editora, 2012. p. 62-65.

SCHINO, Mirella. Alquimistas do palco: os laboratórios teatrais na Europa. São Paulo: Perspectiva, 2009. . Odin Cinquenta: los espetáculos. In: Revista Primer Acto, 2014.

SCHECHNER, Richard. Performance Studies: An introduction. Second Edition. New York: Routledge, 2006. Press, 1985.

Between Theater and Anthropology. Philadelphia: University of Pennsylvania

O Treinamento em uma perspectiva intercultural. In: A Arte Secreta do Ator. Um dicionário de Antropologia Teatral. BARBA \& SAVARESE. São Paulo, É Editora: 2012, p. 291-299.

SENNETT, Richard. O Artífice. Rio de Janeiro: Record, 2009.

SERRANO, Daniela Maria Santos et al. Uso do som crepitante grave (modelo vocal fry) nas Laringectomias Parciais Verticais. In: Distúrbios da Comunicação, São Paulo, 17(1): 19-25, abril, 2005. Disponível em: <http://revistas.pucsp.br/index. php/dic/article/view/11678>. Acesso em: 27/03/2014.

SOBRADO, Tatiana. Voz no corpo gritante: os desafios do processo solo de ator. $291 \mathrm{f}$. Tese (Doutorado em Artes Cênicas). Universidade de São Paulo. ECA-USP, 2014. (Inédito).

STANISLAVSKI, C. A Criação de um papel. Rio de Janeiro: Civilização Brasileira, 2011. A preparação do Ator. Rio de Janeiro: Civilização Brasileira, 1999.

A Construção da Personagem. Rio de Janeiro: Civilização Brasileira, 1989a. Minha vida na arte. Rio de Janeiro: Civilização Brasileira, 1989b. Manual do ator. São Paulo: Marins Fontes, 1997. Acción - "O Si", as "Circunstâncias Propostas" (Capítulo 3); Comunicación (Capítulo 10) e La Actitud escênica interna (Capítulo 14) in El Trabajo del actor sobre si mismo en el proceso creador de las vivencias. Tradução Jorge Saura. Barcelona: Alba Editorial, 2003.

SPERBER, Suzi Frankl, Parada de Rua - Uma simbiose criativa: Kai Bredholt e LUME. In: Revista do Lume. UNICAMP-Universidade Estadual de Campinas/ LUME-Núcleo Interdisciplinar de Pesquisas Teatrais-COCEN-UNICAMP. Campinas, $\mathrm{n}^{\circ}$ 4, ago 1999. P. 5562. Disponível em: Disponível em: 
$<$ http://www.cocen.unicamp.br/revistadigital/index.php/lume/issue/archive $>$ Acesso em: 09/07/2014.

STEFÂNIA, Alice. Diálogos com Barba. In: Mimus. Revista on-line de mímica e teatro físico. Ano 1. n. 2, 2009. Disponível em: < http://www.mimus.com.br/4barba2010.pdf >. Acesso em: 31/05/2014.

TAVIANI, Ferdinando. Interculturalismo y Política em El Ur-Hamlet de Barba. In: Primer Acto, n. 346, 1/2014. P.38-47.

TOLENTINO Cristina. Teatro Contemporâneo. In: Revista Digital Caleidoscópio Art, Seção Cultural, Dramaturgia, 2006. Disponível em: <http://www.caleidoscopio.art.br/culturalteatro-contemporaneo.html>. Consulta em: 15/02/2012.

VARLEY, Julia. Pedras d'agua - bloco de notas de uma atriz do Odin Teatret. Brasília: Teatro Caleidoscópio Ed. Dulcina, 2010.

. Viento ao oeste: novela de un personaje. Trad. Lluís Masgrau. Holstebro: Odin Teatrets Forlags, 1997.

VERSIANI, Daniela Beccaccia. Autoetnografias: conceitos alternativos em construção. Rio de janeiro: 7 Letras, 2005.

VIANNA, Klauss. A dança. São Paulo: Siciliano, 1990.

VILLAR, F.P e DA COSTA, J. Operando nas fronteiras: Três apontamentos sobre perspectivas metodológicas. In: Metodologias de Pesquisa em Artes cênicas. Org. CARREIRA, André; CABRAL, Biange; RAMOS, Luiz Fernado; FARIAS, Sérgio C. Memória ABRACE IX. Rio de Janeiro: 7 Letras, 2006.

WINTHER, Frans. The composer Tradition. In: ANDREASEN, John, KUHLMANN, Annelis. Odin Teatret 2000. Aarhus: Aarhus University Press, 2000. P. 85. ISBN 87-7288$872-5$.

\section{PROGRAMAS DE ESPETÁCULOS}

NORDISK TEATERLABORATORIUM ODIN TEATRET. Ave Maria. Atriz: Julia Varley. Texto e direção: Eugenio Barba. Assistente de direção: Pierangelo Pompa. Montagem sonora: Jan Ferslev. Tradução (espanhol): Rina Skeel. Holstebro: junho de 2013.

NORDISK TEATERLABORATORIUM ODIN TEATRET. Doña musica's butterflies. Direção: Eugenio Barba. Texto e cenografia: Julia Varley. Luzes: Knud Erick Knudsen. Gráfica: Marco Donati. Música: Jan Ferslev e Frans Winther. Holstebro: s/d.

NORDISK TEATERLABORATORIUM ODIN TEATRET-FARFA. Itsi-bitsi. Texto: Iben Nagel Rasmussen. Direção e montagem do texto: Eugenio Barba. Arranjos Musicais: Jan Ferslev e Kai Bredholt. Produção de Teatro Potlach e Nordisk Teaterlaboratorium com contribuição de Teaterrådet. Holstebro: s/d. 
NORDISK TEATERLABORATORIUM ODIN TEATRET. Judith. Com Roberta Carreri. Texto: Eugenio Barba e Roberta Carreri. Direção: Eugenio Barba. Escultura: I Wayan Sukarya. Arranjos musicais: Jan Ferslev. Design gráfico: Hans Krull. Fotos: Tonnyt D’Urso. Coprodução: teatro tascabile, Bergamo-Centro Teatrale San Geminiano, Modena- Certro per la Sperementazione e la Ricerca, Ponteder- Centro Teatrale Europeo "Tino Buazzelli, Frascati- Nordisk Teaterlaboratorium. Holstebro: s/d.

NORDISK TEATERLABORATORIUM ODIN TEATRET. La vida cronica. Textos: Ursula Andkjær Olsen, Odin Teatret. Atores: Kai Bredholt, Roberta Carreri, Jan Ferslev, Elena Floris, Donald Kitt, Tage Larsen, Sofia Monsalve, Iben Nagel Rasmussen, Fausto Pro, Julia Varley. Dramaturgia: Thomas Bredsdorff. Assessor literário: Nando Taviani. Desenho de luz: Odin Teatret. Assessor de iluminação: Jesper Kongshaug. Espaço cênico: Odin Teatret. Assessores do espaço cênico: Jan de Neergaard, Antonela Diana. Música: melodias tradicionais e modernas. Vestuário: Odin Teatret, Jan de Neergaard. Desenhos: Giulia Capodieci. Poster: Peter Bysted. Diretor técnico: Fausto Pro. Assistentes de direção: Raúl Iaiza, Pierangelo Pompa, Ana Woolf. Direção e dramaturgia: Eugenio Barba. Tradução do programa (espanhol): Ana Woolf. Holstebro: setembro de 2011.

NORDISK TEATERLABORATORIUM ODIN TEATRET. The Castle of Holstebro. Direção: Eugenio Barba. Texto: Julia Varley e Eugenio Barba. Arranjo musical: Jan Ferslev Iluminação: Poul Östergaard e Knud Erick Knudsen. Gráfica: Marco Donati. Tradução (espanhol) Rina Skeel.Coprodução Teatro Tascabile, Bergamo - Nordisk Teaterlaboratorium, Holstebro: s/d.

\section{MEIOS ELETRÔNICOS}

\section{SOBRE ODIN TEATRET}

<http://www.odinteatret.dk/about-us/eugenio-barba.aspx> Acesso em: 12/08/2012 e 26/04/2014.

<http://www.odinteatret.dk/about-us/eugenio-barba/doctor-honoris-causa-speeches.aspx > 26/04/2014.

<http://www.odinteatret.dk/media/41023/2003,\%20Warsawa\%20Univ\%20\%20SP\%20Discurso.pdf>. Acesso em: 13/08/2012.

<http://www.odinteatret.dk/about-us/actors.aspx>. Acesso em 27/04/2014.

$<$ http://odinteatret.dk/arrangementer/2013/maj-2013/odin-teatret-in-china---fullprogramme.aspx > Consulta em: 22/04/2014.

<http://www.odinteatret.dk/events.aspx>. Consulta em: 27/06/2014.

<http://www.odinteatret.dk/media/41023/2003,\%20Warsawa\%20Univ\%20\%20SP\%20Discurso.pdf> Consulta em: 13/08/2012 e 11/06/2014. 
<http://www.odinteatret.dk/media/217060/INDEX\%20OF\%20CONCEPTS\%20-

Sept\%2010\%20-\%20en.pdf> Acesso em: 01/03/2014.

$<$ http://www.odinteatretarchives.com/MEDIA/DOCUMENTS/EB_LLANEZA_Y_VAIVEN. pdf>. E tradução em português em: <http://www.nortea.com.br/Nortea/artigo-Mestres....html> Acesso em: 12/07/2014.

<http://www.odinteatretarchives.com/odinstory/video-kai-bredholt-2009> Acesso em: 07/06/2014.

<http://www.odinteatretarchives.com/odinstory/video-else-marie-laukvik-2009> Acesso em: 08/06/2014.

<http://www.odinteatret.dk/productions/work-demonstrations/my-stage-children.aspx > Acesso em: 17/05/2014.

<http://www.odinteatretarchives.com/thearchives/the-document-archives/441> Acesso em: 07/05/2014.

<http://www.odinteatret.dk/workshops/odin-week-festival.aspx> Acesso em: 02/12/2013.

<http://new.livestream.com/OdinTeatretLiveStreaming/50years> Acesso em: 20/08/2014.

<http://new.livestream.com/OdinTeatretLiveStreaming/Odinweek2014/videos/60565420> Acesso em: 20/08/2014.

<http://aartesecretadoator.blogspot.com.br/> Acessos em: 07/05/2012, 01/02/2013, 24/04/2014.

<http://aartesecretadoator.blogspot.com.br/p/informacoes-sobre-ultima-edicao-2013.html>. Acesso em: 30/04/2014.

<http://performatus.net/uma-carta-para-recordar/> Acesso em 21/04/2014.

<http://redimunho.wordpress.com/2010/05/12/eugenio-barba/> Acesso em: 18/01/2014.

<http://www.questaodecritica.com.br/2011/11/a-arte-secreta-do-ator-teoria-e-pratica-nobrasil/>. Acesso em: 24/04/2014.

<http://youtu.be/mvZLVY7jBJc> Acesso em: 08/06/2014. (Sessão de trabalho com Frans Winther)

\section{OUTROS}

<http://www.alceuvalenca.com.br/musica/?CodFaixa=225> Acesso em: 06/05/2014.

$<$ http://arterussaesovietica.blogspot.com.br/2012/04/bailarino-russo-de-origem-polonesao.html> Acesso em: 28/07/2014. 
$<$ http://michaelis.uol.com.br/moderno/portugues/index.php?lingua=portuguesportugues\&palavra=sinestesia>. Acesso em: 28/08/2014.

<http://www3.eca.usp.br/pos/ppgac/apresentacao/organizacao-das-linhas-de-pesquisa>. Acesso em: 08/06/2013.

<https://www2.dti.ufv.br/danca_teatro/evento/apresentacao/artigos/gt1/leticia.pdf> Acesso em: 27/08/2014.

$<$ http://www.louvre.fr/en/oeuvre-notices/aphrodite-known-venus-de-milo>. Acesso em: $14 / 02 / 2013$.

<http://www.museocasalis.org/nuevaweb/coleccion/criselefantinas-bronces>. Acesso em: 05/06/2014.

<http://pancocojams.blogspot.com.br/2012/09/long-john-lost-john-sound-files-lyrics.html.> Acesso em: 28/04/2014.

<http://portalabrace.org/memoria/vcongressoetnocenologia.htm> Acesso em: 04/06/2014.

<http://www.teatretom.dk/en> Acesso em: 28/06/2014.

<http://www.treccani.it/vocabolario/pernacchia/> Acesso em: 04/04/2014.

<http://www.sbtcc.org.br/> tai chi. Acesso em: 03/08/2014.

<http://youtu.be/kNTZLi1mUJA> Acesso em: 22/05/2014.

\section{VIDEOGRAFIA}

BANDONEON EM BUENOS AIRES. Vídeo Instituto Goethe, s/d. Assistido em aula de disciplina ministrada pela Prof. ${ }^{a}$ Dr. ${ }^{a}$ Sayonara Pereira, USP-ECA, 2012. Entrevista com Pina Bausch.

IN THE BEGINNING WAS THE IDEA. Prod. Odin Teatret Film. 1991. Dir. Torgeir Wethal. 71 min. Filme baseado na peça Oxyrhincus (1985-1987).

KAOSMOS. Prod. Poul Østergaard. Coprodução: Statens Filmcentral e Odin Teatret apoiado por Kultufonden. 1998. Dir. Peter Sykes. 83 min.Versão filmada da peça Kaosmos, dirigida por Eugenio Barba.

PHYSICAL TRAINING AT ODIN TEATRET. Work demonstration at Odin Teatret. Prod. Odin Teatret Film. 1972. Dir. Torgeir Wethal. Dur. 54min. Treinamento físico dos atores comentado por Eugenio Barba.

THE ECHO OF SILENCE. Prod. Claudio Coloberti para Odin Teatret Film. 1993. 72 min. Estratégias vocais da atriz Julia Varley para a interpretação de textos. 
THE DEAD BROTHER. Prod. Claudio Coloberti para Odin Teatret Film. 1993. 68 min. Demonstração de trabalho da atriz Julia Varley.

TRACES IN THE SNOW. Dir. Torgeir Wethal. Co-produção entre Document Films, Athen e Odin Teatret Film. 1994. 99 min. Demonstração de trabalho da atriz do Odin Teatret, Roberta Carreri.

TRAINING AT GROTOWSKI'S TEATR-LABORATORIUM IN WROCLAW. Odin Teatret Film in collaboration with "Servizi Sperimentala RAI". 1972. Dir. Torgeir Wethal. Dur. 90 min. Trabalho do ator Ryszard Cieslak com os atores Malou Illmoni e Tage Larsen.

TRAINING FÍSICO EN EL ODIN TEATRET. Odin Teatret Film in collaboration with "Servizi Sperimentala RAI". 1972. Dir. Togeir Wethal. Dur. 54 min. Treinamento dos atores do Odin Teatret com comentários de Eugenio Barba.

TRAINING VOCALE ALL'ODIN TEATRET. Odin Teatret Film. 1972. Dir. Torgeir Wethal. Dur. 40min. Treinamento vocal baseado nas ações físicas.

THE TRANSPARENT BODY. Prod. Claudio Caoloberti para o Odin Teatret Film, com contribuição do Polish Culture Institute of Warsaw University e European Commission Leonardo da Vinci Programme. 2002. Dur. 41min. Conversa entre Eugenio Barba e Iben Nagel Ramunsen sobre o treinamento do ator, com imagens de espetáculos e sua ação junto aos pupilos do grupo Ponte dos Ventos. 


\section{APÊNDICE - PROCESSOS INTERLIGADOS}

\section{Treinamentos e performance com o coletivo Rubro Obsceno}

O Coletivo Rubro Obsceno, formado por integrantes da Cia Magna Mater (Leticia Olivares e Stela Fischer), Cia ARCO (Monica Siedler), Cia Monalisa (Léia Rapozo e Neusa Steiner) e A Má Companhia Provoca (Solange Akierman) é resultado da reunião de mulheres artistas localizadas em São Paulo que se conheceram no Encontro e Festival Vértice Brasil 2010 e se reencontraram na edição do mesmo evento de 2012, realizado em Florianópolis/SC, e que integra as atividades do Magdalena Project. O encontro, as trocas de experiências através de participação em workshops e debates acerca da produção feminina na contemporaneidade afirmaram a vontade de trabalhar em parceria e de estreitar laços entre essas mulheres da rede residentes em São Paulo.

Durante a dissertação foram realizados encontros práticos com o Coletivo Rubro Obsceno (sem a participação de Akierman e Steiner) e aplicação de treinamentos e criação de cenas, de agosto a dezembro de 2013, em locais como o Teatro Heleny Guaíra e salas do Espaço Olido e janeiro e fevereiro de 2014 na ECA-USP. Durante agosto até dezembro revezávamo-nos na aplicação do treinamento, mais configurado como um aquecimento, trazendo propostas das pesquisas ou conhecimentos pessoais de cada uma. Essa prática durava uma hora no total dos encontros de, em média, três horas, variando em frequência de uma a duas vezes por semana, mas chegando também a acontecer quinzenalmente. Durante os meses de janeiro e fevereiro, realizamos encontros diários nos quais as integrantes aceitaram que eu aplicasse os treinamentos a fim de testar experimentações para esta pesquisa. $\mathrm{O}$ tempo era dividido entre duas horas de treinamento coletivo ministrado por mim e duas horas voltadas para a criação de cenas, em um trabalho mais individual de experimentação e montagem dos materiais, visando uma performance coletiva sobre o tema "Solidão". Na dinâmica anterior, revezávamo-nos nos papel de "direção", assistindo umas às outras e dando sugestões de dramaturgia, cortes ou feedbacks sobre o efeito da cena.

Pautada em depoimentos pessoais das atrizes/performers sobre estados de solidão, com ênfase na solidão feminina, a ação cênica acontece em um espaço privado/íntimo delineado por quatro ambientes separados por tecidos. Os ambientes propostos apresentam recortes de estados de isolamento, autorretratos de momentos de solidão e solitude em locais domésticos (sala, banheiro, quarto, escritório de uma casa ou apartamento), que puderam ser 
visitados pelos espectadores em um percurso sem hierarquia ou linearidade. As quatro ações acontecem simultaneamente. Minha ação se baseou no excesso de referências e a angústia da produção intelectual que isola. Não há texto, somente palavras sussurradas eventualmente. Durante a ação escrevia em minha pele "Só sei que nada sei" em partes diferentes do corpo, como na perna e antebraço. Também rasgava folhas de um livro e as mastigava, deixando que meu corpo reagisse ao gosto e à textura do papel.

O work in progress intitulado Em si mesmas foi apresentado no III Simpósio Internacional de Reflexões Cênicas Contemporâneas, Campinas, fevereiro de 2014, em formato de looping, ou seja, initerruptamente, durante vinte minutos, permitindo que os espectadores transitassem ao redor dos quatro nichos.

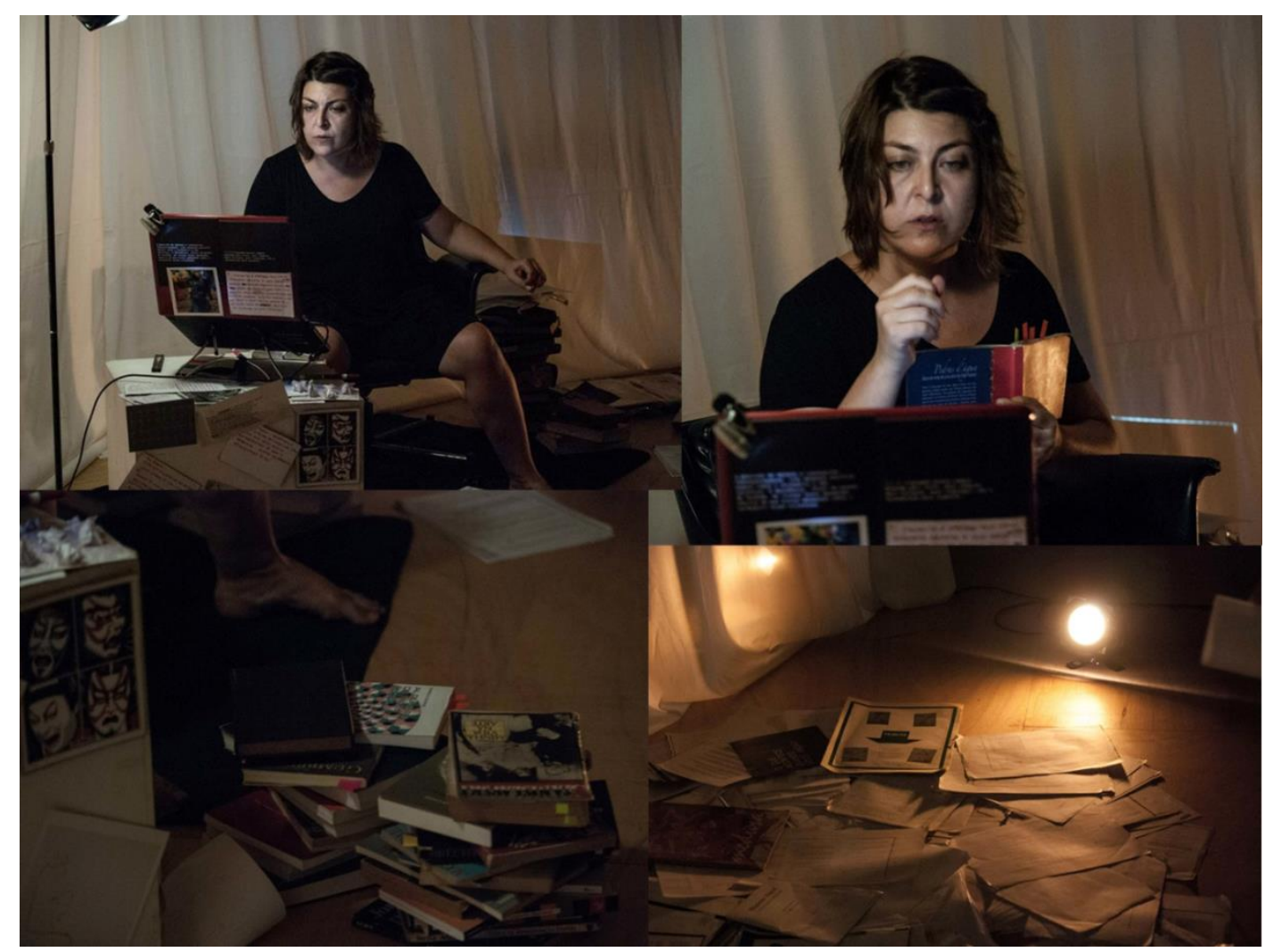

Figura 40. Em si mesmas. Campinas, UNICAMP, 2014. Fotos: Daniela Versiani. Montagem: Leticia Olivares 


\section{Treinamentos e performance com a Cia Magna Mater}

Encontros semanais com a Cia Cênica Magna Mater (Leticia Olivares e Stela Fischer) com aplicação de treinamento físico e criação de partituras corporais (março a novembro de 2012). O resultado cênico foi [des]velhecer, com tema sobre envelhecimento da mulher. Foram realizadas entrevistas com idosas no Sesc Vila Mariana e com as avós das atrizes e este material de áudio serviu de impulso para a dramaturgia corporal. Este trabalho foi apresentado como work in progress no Encontro e Festival Vértice 2012, em Florianópolis.

\section{Processo com a Cia Trilhas da Arte}

Aplicação de treinamento atoral na Cia Trilhas da Arte - Pesquisas Cênicas (janeiro a outubro de 2012) e encenação da peça CATADIÓPTRICO, que ficou em cartaz de Outubro a Dezembro/2012 no Estação Caneca.

Descrição de Atividades aplicadas junto à Cia Trilhas da Arte:

- Laboratórios e estudos práticos e teóricos coordenados por Leticia Olivares (autores estudados Jerry Grotowski, Hans-Thies Lehmann, Eugenio Barba, Richard Schechner, Sayonara Pereira).

- Ênfase no treinamento atoral - procedimentos: treinamento físico (Técnicas de Pilates, dança moderna e técnicas vocais); Rasaboxes; criação de partituras corporais e vocais a partir do treinamento do Odin Teatret; construção e desconstrução de células cênicas (a partir de estímulos por imagens, dança, experiências pessoais dos atores, questionário sobre o processo); processo colaborativo; dramaturgia em processo.

- O material de cena, através de recortes, repetições e composições, selecionado pela direção, configurou-se em uma dramaturgia corpóreo-textual encenada no espetáculo. 


\section{Sobre o espetáculo}

Pensamos habitor lugares, mos habitamos recortes no Tempo. 0 dia e a noite. As fases do Luo. As estaccoes do ano o periado letivo. A Histono da Humanidade. A idade. Os meses. A duraçäo do espetóculo. A grade de programaça da TV. A grovidez e o parto. A reunico. A felícidade. 0 omor. O silêncio.

\section{catadióptrico}

ca.ta.di.óp.tri.co

adj (gr katadioptrikós) Fis 1. Relativo ou pertencente tanto à reflexão quanto à refração da luz. 2 . Diz-se de qualquer instrumento de óptica em que se combinam os efeitos da luz reflexa retratada, ex. "olho de gato".

Catadióptrico. Apropriação. 1.Obra hibrida de caráter multifacetado 2 . 0 que queremos refletir.

Por reflexão catadióptrica entende-se a reflexão caracterizada pelo reenvio da luz em direçōes vizinhas da que a originou. Quatro atores refletem os estados em que somos colocados perante o tempo, a sociedade, os nossos rituais, os nossos medos, os nossos ridiculos, as nossas vontades. Busca-se transitar, no mínimo tempo, entre experiências sensoriais, sem uma narrativa linear, privilegiando as sensacōes provocadas.

Em nosso papel catadióptrico, como artistas cuja utilidade é percebida quando uma luz incide sobre nossa superficie, buscamos iluminar e esconder os princípios da construçẩo cênica em um jogo que coloca em xeque o "quem", o "onde" e o "quando".

Durante cenas divididas em minutos variáveis e sem conexões aparentes, - tempo é manipulado pelos atores em saltos entre temas que dizem respeito desde o comportamento social à criação do universo, bem como a funçấo do artista.

O cenário e os figurinos salientam a deformação causada no tempoespaço pela nossa simples presença. No figurino, ainda temos referências às cores do prisma e aos quatro elementos.

Nesta montagem, apoiada no teatro físico, nosso próprio ofício entra em foco. O que temos a oferecer? Nossos estados, sensaçōes e suor. O sangue correndo em nossas yeias. A nossa pulsacào Um corpo-dispositivo que britha quando a tuz de cada espectadorincide sobre ele.

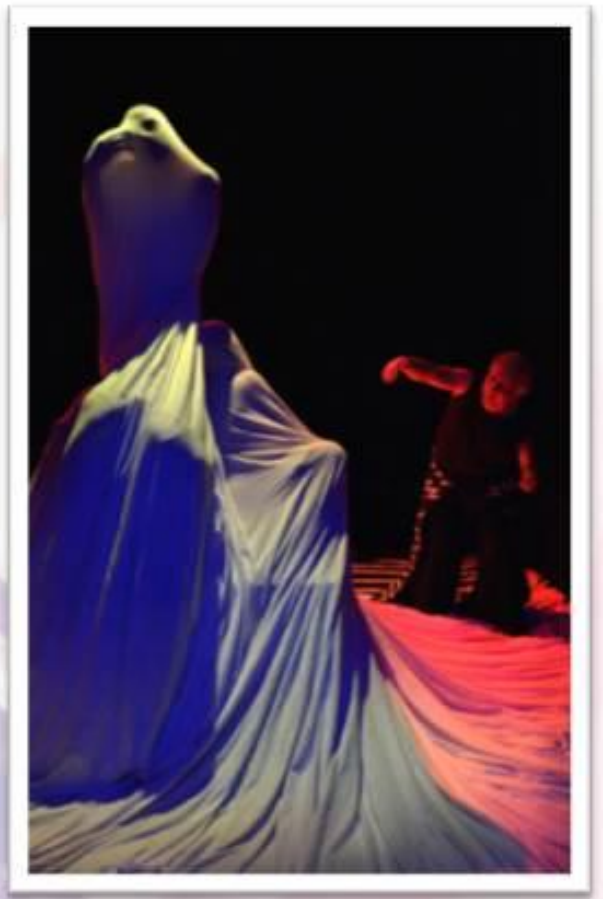

Leticia Olivares

\section{Fi.cha Téc.ni.ca}

Roteiro original: Monalisa Vasconcelos Dramaturgia coletiva

Organização dramatúrgica e Direção: Leticia Olivares

Elenco: Antonio Ginco, Jutiana Calligaris, Lucas Barbosa, Monalisa Vasconcelos

Preparação corpora: Leticia Olivares

Preparação vocal: Juliana Calligaris

Cenário e figurinos: Paulo de Moraes

Iluminação: Fábio Reginato e Lucas Barbosa

Tritha sonora: Leticia Olivares

Operação de luz: Leticia Olivares

Operação de som: Clarissa Otivares Rodriguese Pedro Darween

Fotos: Fábio Reginato e Jeferson Kim

Produção gráfica: Livia Maia e Maura Hayas

Produção geral: Trilhas da Arte Pesquisas Cênicas
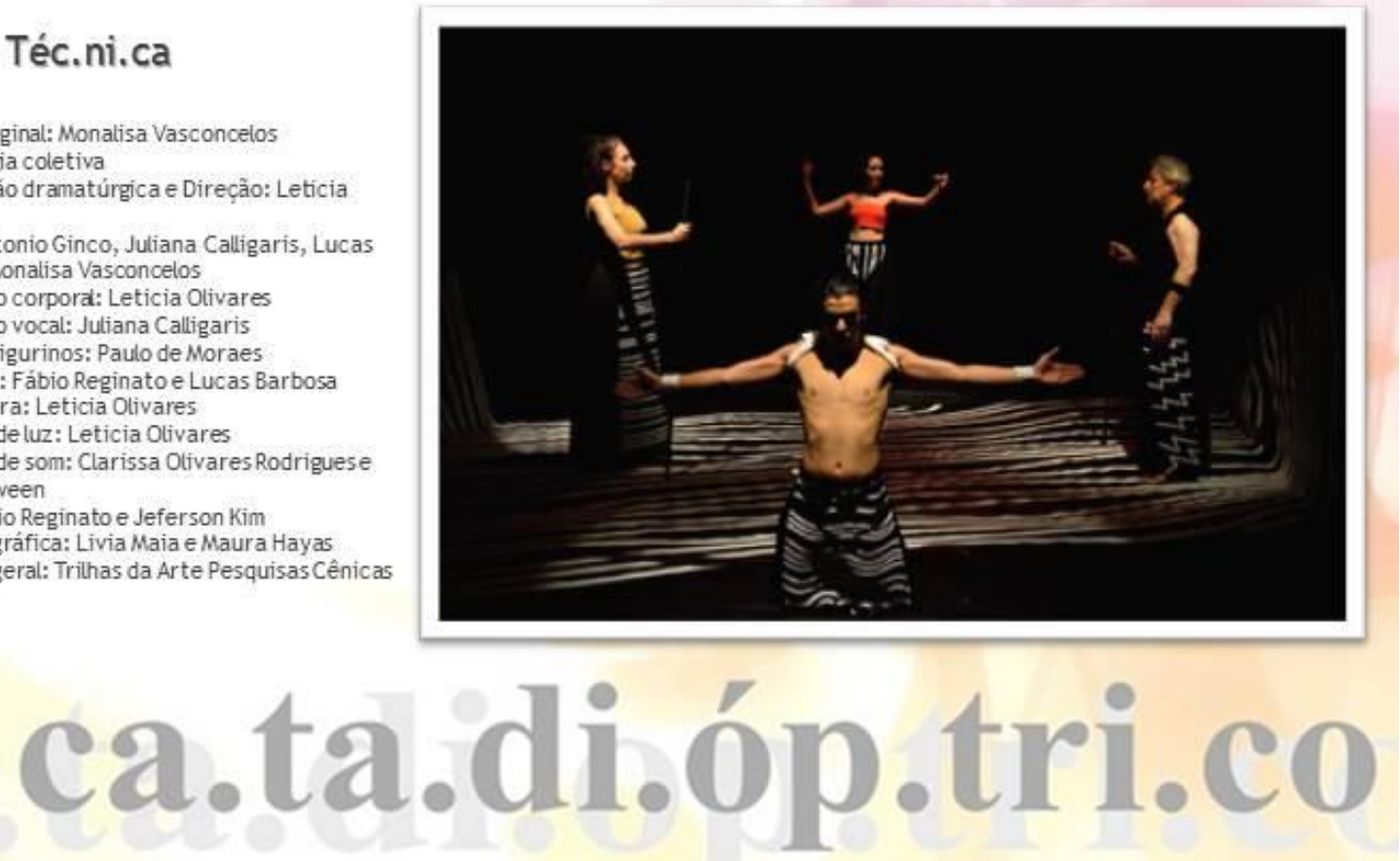

Figura 41. Catadióptrico. Fotos: Fábio Reginato, 2012. Montagem: Leticia Olivares. 


\section{ANEXO A - Orientações A ARTE SECRETA DO ATOR - BRASIL, Brasília, 2010 (excerto).}

\section{IMPORTANTE}

\section{MATERIAL A SER DESENVOLVIDO PREVIAMENTE PELOS ATORES SELECIONADOS PARA O WORKSHOP}

Os atores deverão escolher e decorar UM POEMA* que aborde o tema A FLOR DAS IDADES (sobre ser jovem ou envelhecer) e elaborar UMA CENA** prévia, a partir desse texto, contendo além dele, ações ou partituras físicas, ações vocais, música e o que mais achar necessário dentro da sua tradição de trabalho e dramaturgia. Esta cena sobre A Flor das Idades deve estar pronta para ser apresentada na manha do primeiro dia do treinamento (11 de dezembro) e deverá ter, no máximo, 5 minutos. Este material será apresentado como um "cartão de visita", será a célula de uma performance, que poderá ser ou não usada pelo diretor ao longo dos dias de treinamento e criação. É importante que esteja seguro para ser usado no todo ou em partes, seus textos ou ações juntos ou isolados.

* Cada participante deve trazer três cópias dob poema que usou como base do trabalho e com um briefing sobre o seu autor para entregar para Eugenio Barba e Julia Varley no primeiro dia do treinamento.

** As cenas devem ter apenas 5 minutos, cronometrem durante ensaio para que este requisito seja cumprido. Elas não devem contar com recursos técnicos elaborados, 0 material dramático deve ser simples e orgânico, o ator poderá sozinho realizar sua cena, na sala, ao ar livre, a luz do dia, sem necessidades que a impeçam de ser feita. Pedimos também a otimização do tempo entre as apresentações. Para quem precisar estará disponivel um reprodutor de CDs.

Além deste material, cada ator, deve ter decorado como opção extra, uma canção de sua preferência e escolher um dos poemas abaixo do poeta persa Omar Khayyam para também ter decorado. Todo este material (poemas, musicas e ações) não sistematizado como teatro será o conteúdo de referência para o treinamento e para a construção de uma dramaturgia ao longo dos dias desta edição que tem a poesia como ponto de partida.

Os diretores, estudiosos ou acadêmicos selecionados como observadores do processo de criação e direção de Barba, não farão as atividades práticas, portanto, não necessitam decorar ou preparar material.

\section{POEMA 1}

Sinto que a minha mocidade refloresce.

Desejo aquele vinho

que me dá calor e alegria...

Quero vinho...

Dizes que é amargo?

Não importa.

Tem o gosto da vida.

\section{POEMA 2}

Estou velho, e a paixão que me inspiraste arrastar-me-á ao túmulo, pois não cesso de encher de vinho a grande taça. Minha paixão por ti tem razão contra mim mesmo... E o tempo desfolha a minha bela rosa... 


\section{ANEXO B - Programação ODIN WEEK, Holstebro, 2013 (excerto).}

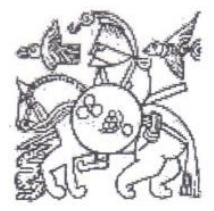

\section{ODIN WEEK FESTIVAL PROGRAMME 19 - 29 August 2013}

Monday 19

$16.00-17.00$ :

17.00:

18.15:

18.30

19.30:

20.00

Tuesday 20

$07.30-08.30$

$08.30-10.15$ :

$10.15-10.30:$

$10.30-12.00$ :

$12.00-13.30$

$13.30-15.00$ :

$15.00-15.15$ :

$15.15-16.45$

$16.45-17.00$ :

$17.00-18.00$ :

18.15:

18.30:

19.30:

20.00:

Wednesday 21

07.15 - 08.00:

$08.00-08.45$

$08.45-10.45$

$10.45-11.00$

$11.00-13.00$

$13.00-14.30$

$14.30-16.00$

$16.00-16.30$

$16.30-17.30$ :

$17.30-18.15$

18.15:

18.30:

19.30:

$20.00-21.15$

$20.00-21.15$

\section{Registration}

Meeting with Eugenio Barba - White Room

The bus leaves Odin Teatret for supper

Supper at Holstebro Aktivitetscenter

The bus leaves Holstebro Aktivitetscenter and returns to Odin Teatret

THE CHRONIC LIFE (performance with Odin Teatret ensemble) - Red Room

\section{Breakfast}

Information Meeting with Roberta Carreri and presentation of Odin Teatret White Room

Break

The Odin Tradition - Iben Nagel Rasmussen - White Room

Lunch break and cleaning of the theatre

My Stage Children (a stage story by Else Marie Laukvik) - White Room

Break

The Echo of Silence (work demonstration with Julia Varley) - White Room

Break

Meeting with Eugenio Barba on actor's training - Red Room

The bus leaves Odin Teatret for supper

Supper at Holstebro Aktivitetscenter

The bus leaves Holstebro Aktivitetscenter

JUDITH (performance with Roberta Carreri) - Black Room

Running and singing with Kai Bredholt

Breakfast

Training with Roberta Carreri and Tage Larsen - Red and White Room

Break

Traces in the Snow (work demonstration with Roberta Carreri) - Red Room

Lunch break and cleaning of the theatre

The Odin Tradition - Jan Ferslev - Red Room

Break

THE CASTLE OF HOLSTEBRO II (performance with Julia Varley) - Black Room

Break

The bus leaves Odin Teatret for supper

Supper at Holstebro Aktivitetscenter

The bus leaves Holstebro Aktivitetscenter

MEMORIA (performance with Else Marie Laukvik and Frans Winther)

- For the first half on the participants' list - White Room

On the Two Banks of the River - Film - For the second half on the participants' list - Red Room 


\section{ANEXO C - AUTORIZAÇÕES 349}

Holstebro, 18 de junho de 2014.

Autorizamos o uso das entrevistas concedidas a Leticia Maria Olivares Rodrigues para uso acadêmico em sua dissertação de mestrado cursada na Escola de Artes Cênicas da Universidade de São Paulo.
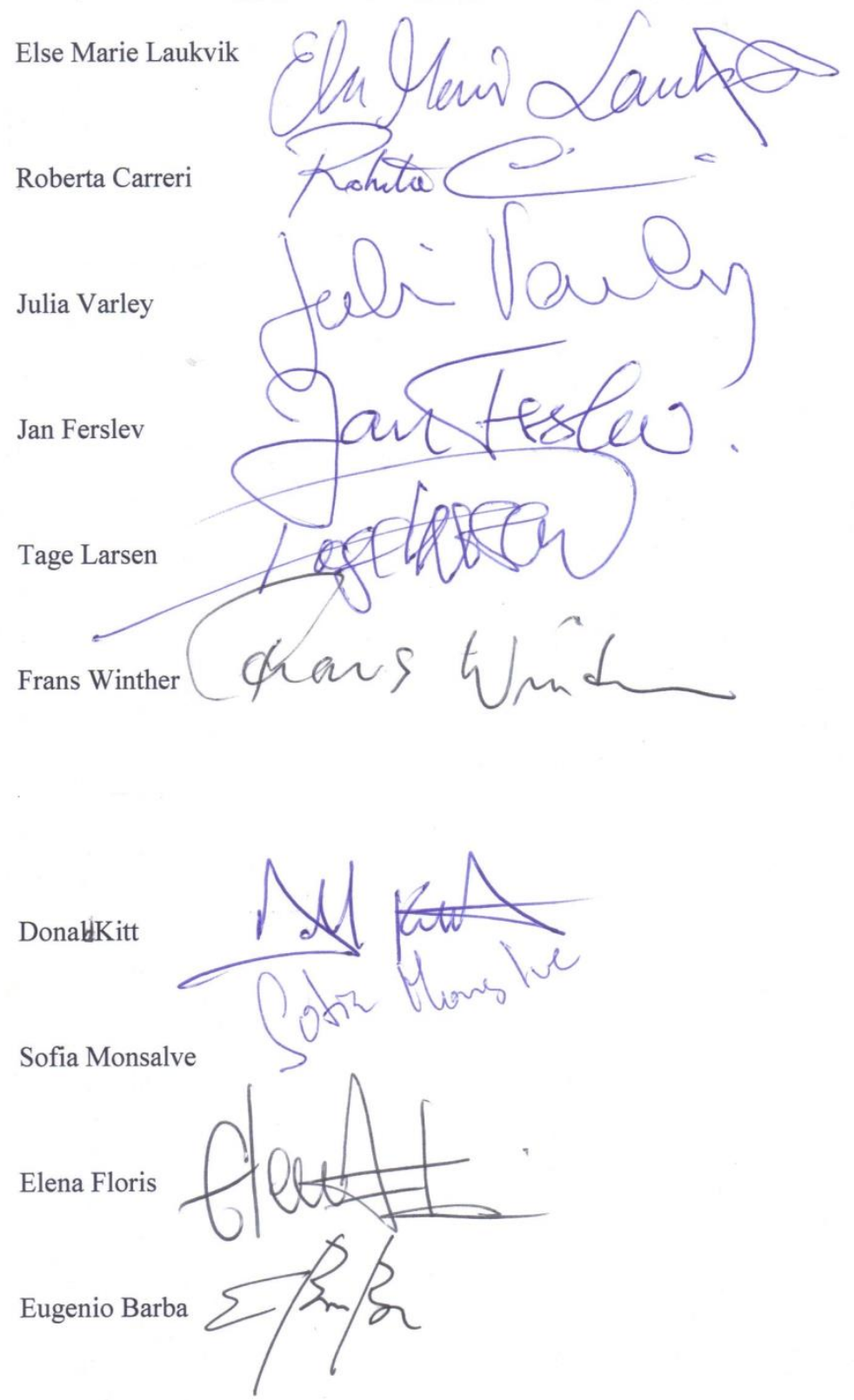

${ }^{349}$ Não foi possível recolher a assinatura de Kai Bredholt, no entanto, temos sua permissão oral para o uso da entrevista. 
ANEXO D - ATIVIDADES DO NORDISK TEATERLABORATORIUM

(folheto referente ao ano de 2012)
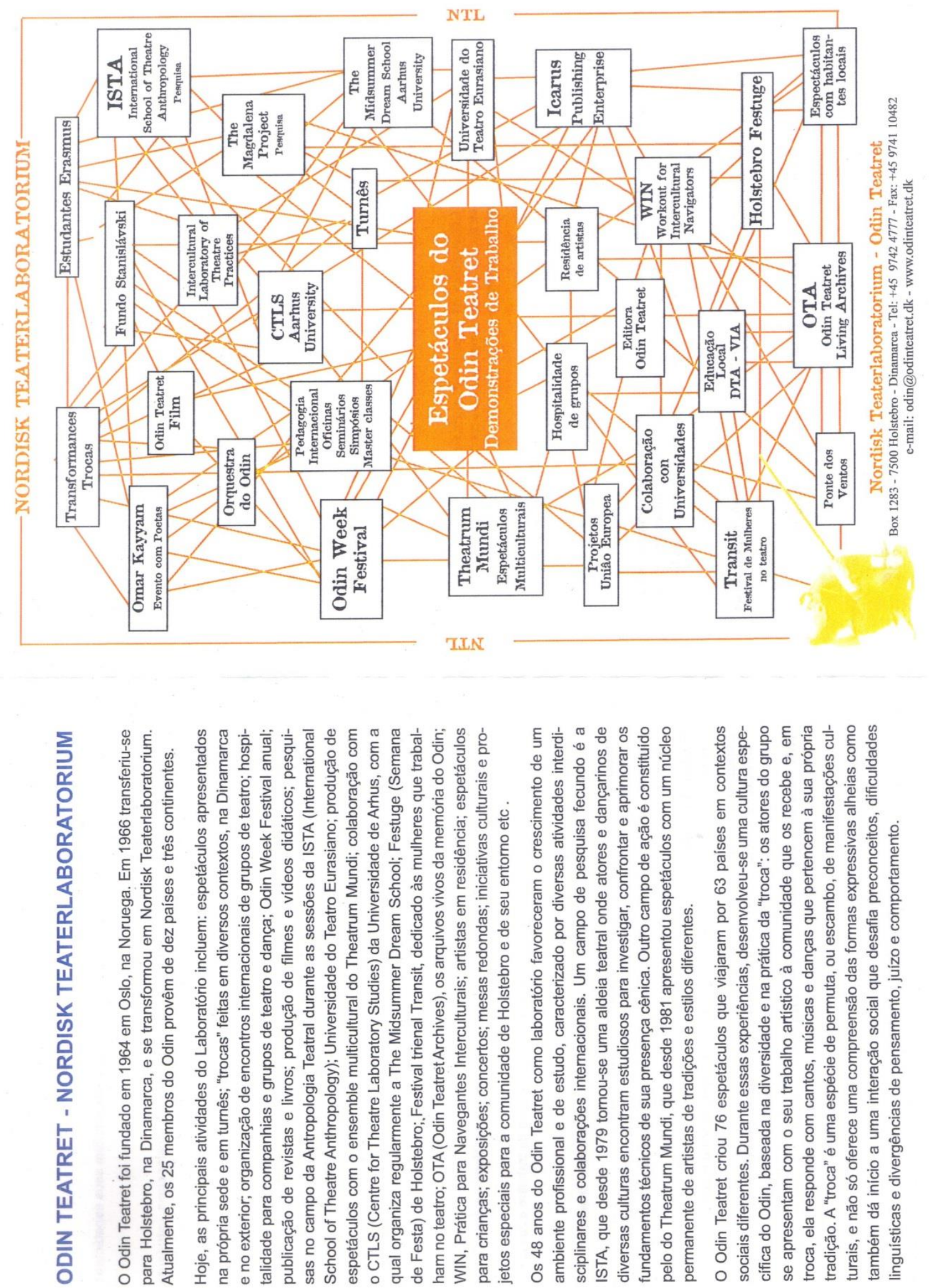

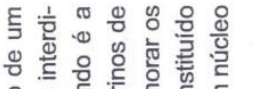

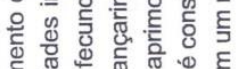

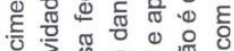

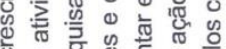

0

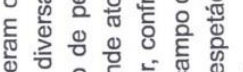

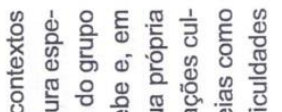

ठํ.

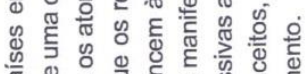

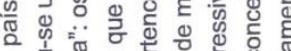

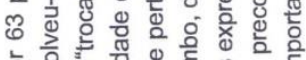

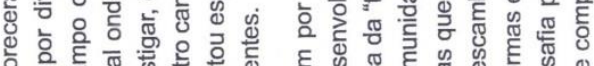

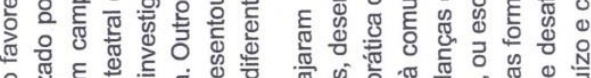

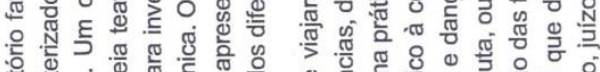

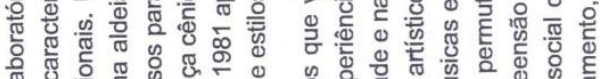
需

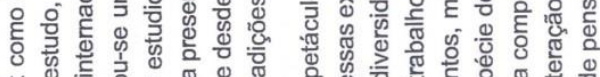
屯․ำ

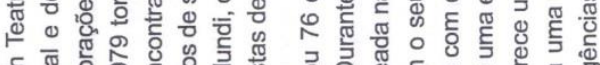

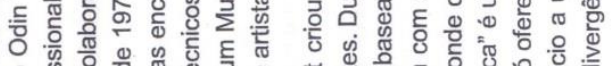
○证 0 ڤ0 क 